Western University Scholarship@Western

Digitized Theses

Digitized Special Collections

1987

\title{
Dynamic Analysis Of Offshore Structures
}

Hisham Mohammed Mitwally

Follow this and additional works at: https://ir.lib.uwo.ca/digitizedtheses

\section{Recommended Citation}

Mitwally, Hisham Mohammed, "Dynamic Analysis Of Offshore Structures" (1987). Digitized Theses. 1603.

https://ir.lib.uwo.ca/digitizedtheses/1603

This Dissertation is brought to you for free and open access by the Digitized Special Collections at Scholarship@Western. It has been accepted for inclusion in Digitized Theses by an authorized administrator of Scholarship@Western. For more information, please contact tadam@uwo.ca,

wlswadmin@uwo.ca. 


\section{Natone Loren \\ of Conede \\ Conadien Theses Sence \\ Orisura Cenece \\ KIA ONA \\ Bbuondar neon:s \\ as Caneda \\ Sernces des undes canediennes}

\section{CANADIAN THESES}

\section{THESES CANADIENNES}

\section{NOTICE}

The quality of this microfiche is heavily dependent upon the quality of the onginal thesis submitied for microfiming Every eftor has been made to ensure the highest quaity of reproduction possible

If peges are missing. contact the unversity which granted the degree

Some pages may have noistinct print especially it the orkonal pegos were typed with a poor typowitter rbbon or th the university sent us an intenor photocopy

Previousty copyrighted materiats (poumal ancles. Dublished tests. otc) are not filmed

Reproduction $n$ full or in pent of this film is governed by the Canadian Copyroht Act. R S C 1970. C C-30
- La quahte de conte microfiche depend grandement de la qualite de la th so soumuse au mucrofimage Nous avons tout tart pour assurer une qualite superieure de reproduction

S'il manque des pages, veurliez communnquer avec liuniversté our a contere le grade

La quaite ofmpression de cenames pages Deur laisser a desrer. suntout si les peges ongnales ont ete dactylographiees a lade ofun ruban use ou si l'universite nous a fart parvenir une photocopre de qualite inferieure

Les documents qui tont deja robet ó un droit d avteur (articies de revue. examens publids, etc ) ne sont pas microfilmes

La reproduction. mome partielle, de ce microfilm est soumise a la La cenedienne sur le drot d'auteur, SRC 1970, C C-30

\section{THIS DISSERTATION HAS BEEN MKROFILMED EXACTLY AS RECEIVED}

\author{
LA THESE A ETTE \\ MICROFILMEE TELLE QUE \\ NOUS L'AVONS REÇUE
}



Permission has been granted to the National Library of Canada to microfilm this thesis and to lend or sell copies of the film.

The author (copyright owner) ha reserved other publication rights, and neither the thesis nor extensive extracts from it may be printed or otherwise reproduced without his/her written permission.
L'autorisatzon a été accordée d la Bibliotheque rationale du Canada de microfilmer rete those et de prêter on de ventre does exemplaires du ti lu.

Hauteur (titulaire du droit d'auteur) se reserve les autres droits de publication; ni la these ni de longs extracts de celle-ci ne doivent ere imprimés out autrement reproduits sans son autorisation écrite.

ISBN $\quad 0-315-36086-8$

$\therefore$ 
The author of this thesis has granted The University of Western Ontario a non-exclusive license to reproduce and distribute copies of this thesis to users of Western Libraries. Copyright remains with the author.

Electronic theses and dissertations available in The University of Western Ontario's institutional repository (Scholarship@Western) are solely for the purpose of private study and research. They may not be copied or reproduced, except as permitted by copyright laws, without written authority of the copyright owner. Any commercial use or publication is strictly prohibited.

The original copyright license attesting to these terms and signed by the author of this thesis may be found in the original print version of the thesis, held by Western Libraries.

The thesis approval page signed by the examining committee may also be found in the original print version of the thesis held in Western Libraries.

Please contact Western Libraries for further information:

E-mail: libadmin@uwo.ca

Telephone: (519) 661-2111 Ext. 84796

Web site: http://www.lib.uwo.ca/ 
of offshore structures to environmentsl loads whlch are mainly dynamle. "It alers the dynamte propertles of the structure and may increase or decrease the response depending on the relatlonshlp of the fundamental natural frequency to the dominant exclting frequency. Random wave forces on oftshore towers are usually evaluated using the directlonal spectrum of sea surface elevation. Thls representation does not take Into account the lack of spatlal correlation which may be assoclated with fully developed random waves.

\subsection{Objectives of the Study and Organization of the Thesis}

Thls study is divided Into two main parts. The nrst part deals with the plle drlvabllty analysis. The second part is concerned with the response of nxed onshore structures to random wave forces. The objectlves of the nrst part are:

- 1. To improve on the one dimensional wave equation analysis of plle drivablitty by accounting. In a rational way. for wave propagation in the soll and by formulating parameters related to standard soll characteristles.

2. To formulate a three dimenslonal innlte element analysls with sultable transmitting boundarles and compare tis results to those of the one dimenslonal analysls in order to lllustrate the advantages, and .llmitatlons of both models.

In the second part of the study. the analysls is llmited to the Jacket type platforms or towers. and the objectlves are:

1. To examine the efrect of dynamic plle-soll-plle Interaction on the response of nxed oftshore towerg to random wave forces.

2. To establish an approach for evaluating random wave loads on offshore towers which takes into sccount the lack of spatial correlacton of raindom waves and allow for directlonal effects.

Chapter 2 glves a brlef revlew of different types of offshore structures, maln sources of environmental loads and the Important parameters that govern the behavlour of these structures. In Chapter 3, the one dimenslonal wave equation 




\section{Table of Contents}

Certificate of Examination

Abetract

iii

Acknowledgemento

iv

Table of Contents

List of Figures

$\mathbf{x}$

List of Tables

$x v$

Chapter 1 - Introduction ............ . 1

1.1 General ........... . . . . . . .

1.2 Objectlves of the Study and Organization of the Thesls . . . . . 2

Chapter 2-Review of Oftrhore Structures ........... 4

2.1 Types of Ortshore Structureg $\ldots \ldots \ldots \ldots \ldots \ldots \ldots \ldots$

22 Envilonmental Loads ..................... 8

Chapter 3 - One Dimensional Analysis of Pile Driving . . . . . 12

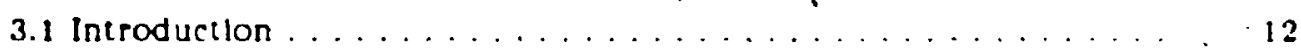

3.2 Wive Equation In Plle Drlving Anslysts . . . . . . . . . . 13

3.2.1 One Dimensional Wave Equation .............. 13

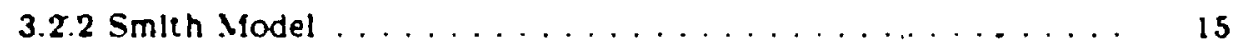

3.3 Soll Reslstance During Driving . . . . . . . . . . . . . . . . 20

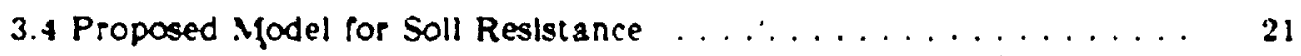

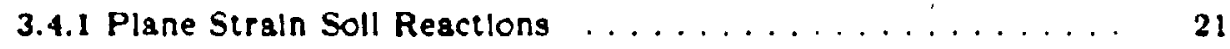

3.4 .2 Soll Surrness and Damping . . . . . . . . . . . . 24

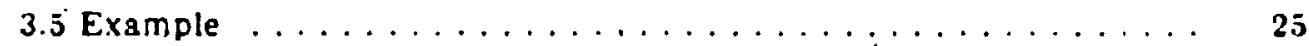

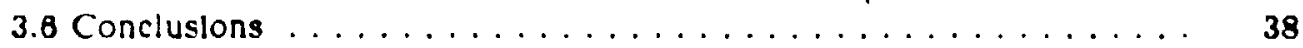

Chapter 4. Three Dimensional Analyois of Pile Driving . . . . . . 39

4.1 Introduction .......................... 39

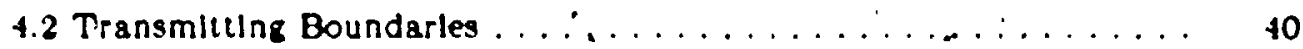

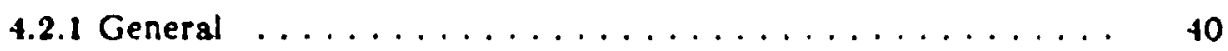

4.2.2 Plane Strain Transmlttine Boundary . . . . . . . . . 42

4.2.3 Homogeneous Medlum . . . . . . . . . . . . 43

4.2.4 . Nonhomogeneous Medlum . . . . . . . . . . 45

4.3 Implementation of the Plane Straln Transmitting Boundary . . . . 49

4.3.1 Finlte Element Formulation . . . . . . . . . . . 49 
4.3.2 Boundary Sumness and Damping Matrlies . 52

4.t Vertncation of the Plane Strain Transmlting Bun tart . j5

45 Interface Element. . . . .......... . 60

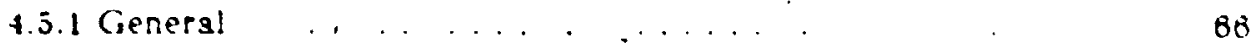

4.5.2 Formulation . . . . . . . . . . .

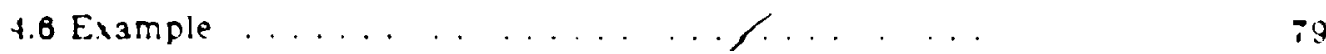

4.7 Conclustons . . . . . . . . . . . . . . . . . 81

Chapter 5 - Foundation Model For Fixed Offohore Towers . $\quad 84$

5.1 Introduction ....................... 84

5.2 impedance Functions of Single Plles . . . . . . . . . 8.5

5.2.1 Silnness Matrix of a SIngle Plle ... . . . . . . 8.5

5.2.2 Review of Exlsting Solutions for Impedance Funcilons . $\quad 88$

5.2.3 Plane Straln Impedance Functions . . . . . . . . . . . 91

5.2 .4 . Vonllnearlty . . . . . . . . . . . . . . 92

5.3 Plle Group Behaviour . . . . . . . . . $9 . \ldots \ldots \ldots$

5.4 Interaction factors . . . . . . . . . . . . . . . . . 94

5.4.1 Dynamic Interaction Factors ................ 94

$\mathbf{5 . 4 . 2}$ Static Intersction Factors . . . . . . . . . . . . . . 98

5.4.3 Effect of Phle Separation on Interaction Factors ..... . . .98

5.5 Foundation Stifrness Matrix . . . . . . . . . . . . . . . 104

5.6 Plle Group Impedance Functions . . . . . . . . . . . . . . 105

5.6 .1 Vertleal Group stirrness . . . . . . . . . . . . . . . 105

5.6.2 Horizontal. Rocklng and Crose stlffness of Plle Ginups . . . . 108

$\mathbf{5 . 8 . 3}$ Torslonal Stiffness . . . . . . . . . . . . . . . . . 113

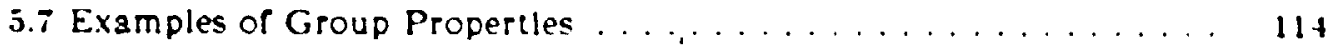

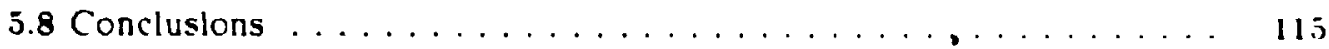

- Chapter 6 - Wave Forces on Offshore Structures . . . . . . . 118

6.1 Introduction ........................ 118

6.2 Revlew of Wave Loading . . . . . . . . . . . . . . . . . 119

6.3 Spectral Denstity of Water Particle KInematles . . . . . . . . . . 124

6.3.1 Stationary Gaussian .Model of Sea Surface Elevation . . . . . 124

6.3.2 Power Spectrum of Sea Surface Elevation . . . . . . . . . 125

6.3.2.1 Unldirectlonal Spectrum (Frequency Spectrum) ..... 126

6.3.2.2 Directlonal Spectrum . . . . . . . . . . . . 128

6.3.3 Water Partlcle KInematles Spectra . . . . . . . . . . . . . 129

6.3.3.1 Directlonal Spectrum Model . . . . . . . . . . . 131

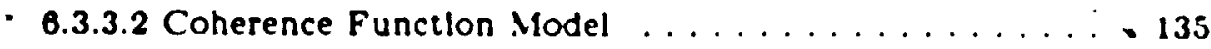

6.4 Wave Forces on Members of Ortshore Towers . . . . . . . . . . . 138

6.5 Directlonal Spectrum Model . . . . . . . . . . . . . 141 
<smiles>[Y]C([Y])=[V]</smiles>

85.1 Formulatlon of Wive Forces . . .

Q 5.2 Parametili Siudy .. . . 113

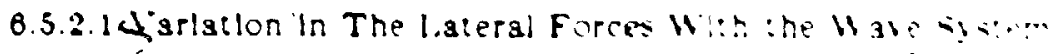
Párameters

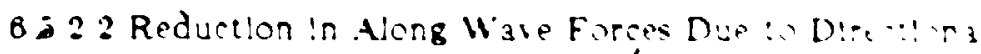
Spresd

- 65.2 .3 Efrect of Lumping the Members s: :he Vin

66 Coherence Function Model

B.B I Formulation

8.8.2 Parametrle Study

$1.5 \%$

6.6 2.1 Varlation in the Ratlo Between the Hat:andal For:.

6 6.2.2 Reduction in Along Wave Fores Due W Lach of Fratia Correlation

6.8.2.3 Efrect of Lumplng the Members at the Yins

\section{Chapter 7 - Reoponse To Random Wave Forces}

i.l Introduction .... . . . . . . . . . . . . . 181

7.2 Structural Ideallzation . . . . . . . . . 182

i.2.1 General . . . . . . . . . . . 182

7.2.2 Stlfrness. Mass and Damping Matrices . . . 18.5

7.2.3 Symmetry ........ . . . 188.

7.3 Cioverning Equations of ligtion ..... . 187

i. Free Vibration Analysis . . . . . . . . . . . . 1 .

is Response to Wave Forces . . . . . . . . . . . . . 192

7.8 Solution Procedure . . . . . . . . . . . . . . . . . . . 19.5

Chapter 8 - Examples and Parametric Studies . . . 198

8.1 Introductión . . . . . . . . . . . . . . 198

8.2 Varlation of Vatural Frequencles and Damplng Rati w wh

Foundation Parameters ...... . . . . 20. 20.

8.2.1 Effect of Soll Stifrness . . . . . . . . . . . . . 20.5

8.2.2 Effect of Soll Promle . . . . . . . . . . . . . . . . . . 207

8.2.3 Errect of Plle Separation . . . . . . . . . . . . 209

8.2.4 Efrect of Plle-Soll-Plle Interaction . . . . . . . . . . 213

8.2.5 Effect of Deck. Mass . . . . . . . . . . . . . . 218

8.3 Varlatlon In Hydrodynamle Damplng and Tower Response io Wave

Forces Hith the Different Parameters . . .......... . 219

8.3.1 Enfect of Soll Stiffness . . . . . . . . . . . . . . . 219

8.3.2 Effect of soll Pronle . . . . . . . . . . . . . . 224 
8.3.3 Effect of Plle-Soll-Pile Interaction.

8.3.4 Effect of Exponential Decay Parameter:

8.3.5 Effect of Deck Mass .

221

8.3.6 Conclusions .

227

230

230

Chapter 9 - Summary and Conclusions Q.1 Pile Driving

234

8.2 Wave Force Spectrum

9.3 Response of Fixed Offshore. Towers

234

8.4 Recommendaslons for Further Research

Appendix A - Stiffness Matrix of Rectangular Axisymmetric Element

A.1 Sone Basic Constants

A.2 Terms of the Upper. Half of the Selfness Matrix.

Appendix B - Wave Force for Directional Spectrum Model.

254

2.54

255

258

$\because \quad$ Appendix C - Wave Forces for Unidirectional Waves

260

Appendix D - Wave Forces Assuming Constant Velocity

261

Appendix E - Wave Forces for Coherence Function Model . . . . 262

Appendix F - Computer Programs lied in the Study

271

Vita

.272

viII 


\section{List of Figures}

Figure 2-1: Steel Jacket Orshore Platform

Figure 2-2: Sinemalle of a Tension Leg Platiorm

Figure 2-3: Guyed Tower Platform

Figure 2-4: Statfjord B Concrete Gravity Piatform

Figure 3-1: One Dimenslonal Ideallzation of the Plle Soll Sysiem 18

Figure 3-2: Force Displacement Relationshlp of Soll Spring

Figure 3-3: ITbration of Plle TIp Around an Equllibrlum Position it

Figure 3-4: Plane Siraln Vertical Reactlons for the Composite 23

Figure 3-5: Comparison of Plle Tip Displacements for Two Mfodels 28

Figure 3-6: Comparlson of Plle Tlp Displacements for Three Models 29

Figure 3-7: Plle TID Displacements for Two Interface Condlitons 30

Figure 3-8: Time History of Veloclty at Plle Top $(\alpha=0.5$ and 32 $C_{s}=100 \mathrm{KPa}$ )

Figure 3-9: Time History of Force at Plle Top $\alpha=0.5$ and $C_{4}=100 \quad 33$ KPa)

Figure 3-10: TIme History of Veloclty at Plle Top $(\alpha=0.5$ and

$$
C_{4}=300 \mathrm{KPa} \text { ) }
$$

Figure 3-11: Time History of Force at Plle TOp $Q=0.5$ and

$$
C_{u}=300 \mathrm{KPa} \text { ) }
$$

Figure 3-12: Plle TIp Displacements for Difrerent Embedded Lengths 36

Figure 3-13: Bearing Capactly and Blow Count for Different 37

Embedded Lengths

Figure 41: Finlte Element Modelling of a Continuum Problem 41

Figure 4-2: Displacement Components In the Cyllndrleal Coordinates 41

Figure 4-3: Plane Straln Axlsymmetrlc Radlal Surfness and Damplng $\quad \mathbf{4 8}$ for a Homogeneous .Medlum

Figure 4-4: Plane Straln Axlsymmetrle Radial Stirfness and Damplng 50 for a Composite Soll Medium

Figure 4-5: Three Dimenslonal Axisymmetric Element

Figure 4-6: Varlation In the Transmliting Boundary Paramrters. $\quad 58$ $S_{1,1}, S_{1,2} / a_{o}$ and $S_{r 2} / a_{o}$, with Frequency

Figure 4-7: Displacement of a Seml Innnlte Elastic Bar subjected in a Constant Load $\left(P_{n} l_{p}^{\prime} / E . A=1 \mathrm{~m} / \mathrm{s}\right)$

Figure 4-8: Normal Stress Dlstrlbution Along an Elastl Bar

Subjected to a Constant load at time $t=3 \mathrm{~L} / 2 I_{p}$ ! 
Figure 4-9: Dlsplacement of an Elastle Bar Subjected to a Harmori:

Load $\left(P_{o} ; E .4=0.002 . T=0.1 \mathrm{~s}\right)$

Figure 4-10: Finlte Element Mesh with Transmlting Boundary $B 1$

Figure 4-1): Vertlcal Statle Stinness of a Single Plle Poulos Solu:ion 63

Compared with Present Solution)

Figure 4-12: Vertlcal Dynamic Stitrness and Damplng of a Single Plle

(Viscous Boundary Compared wilth Plane Strain

Boundary. $a_{0}=0.3$ )

Figure 4-13: Vertlcal Silmness and Damplng or a Single Plle Finlle

Element Solution by Ostadan Compared wilth Present

Solution. $L / r_{0}=30$ )

Figure 4-14: Displacement of Plle Tlp Subjected to a Harmonle Load

(Comparison Between Viscous and Plane Straln

Boundarles based on a time domain analysls): $a_{0}=0.05$

and $L / r_{0}=24$

Figure 4-15: Displacement of a Plle Segment Subjected to a

Harmonic Load (Wu [50])

Figure 4-16: Vertlcal Dynamic Stimness and Damplng of a Rigld

Massless Disc on Halispace

Figure 4-17: Thin Interface Element

Figure 418: Stress Straln Relatlonshlp for Interface Behavlour

Figure 418: Plle Top Displacement With and Without Plle Soll Sllp

$\left(a_{0}=0.08\right.$ and $\left.L / r_{0}=24\right)$.

80

Figure 4-20: Comparison of Plle Tip Dlsplacement for the 1-D and 3D Analyses

Figure 5-1: Votatlon for Plle Head Stiffness Constgnts

Figure 5-2: Two Identical and Equally Loaded Plles

Figure 5-3: Model L'sed to Account for Erfect of Plle Separation on

- Interaction Factors

Figure 5-4: Varlation m-interaction Factors $\alpha_{u u^{\prime}} \alpha_{u u^{\prime}}$ and $\alpha_{u^{\prime}}$. with

Rlle Separation Ratlo (e/d) and Dimenslonless Frequency $\left(A_{o}\right)$ for $S / d=2$ and $\beta=0^{\circ}$

Figure 5-5: Varlation In Interaction Factors $\alpha_{u u}, \alpha_{u \psi}$, and $\alpha_{b q}$, with

Plle Separation Ratio $(e / d)$ and Dimenslonless Frequency

$\left(A_{0}\right)$ for $S / d=2$ and $\beta=80^{\circ}$

Figure 5-6: Varlation in Interaction Factors $\alpha_{u u^{\prime}}, \alpha_{u,}$ and $\alpha_{\text {b. }}$ with

Plle Spacing Ratlo $(S / d)$ and Separation Ratlo $(e / d)$ for $3=0^{\circ}$ and $A_{o}=0.05$ 

Figure 0-12: Varlation in the Approximation Ratlo $R$ : Hilh

Dimenslonless Wave Number, Directlona: Spectrum

Model!

Figure 6-13: Exponenulal Decas Coherence Funct!on

Figura 6-14: Varlation in the Ratlo of Spectra of the Latera! Furie

$16:$

Components with Mean Direction of Wate Adrance

¿Coherence Function Model'

Figure 8-15: Varlation in the Ratlo of Across to Along Wave Forit

Spectra with Mean Direction of Wave Advance ; Both

Mfodels!

Figure 6-16: Varlation in the Ratio of Spectra of the Lateral Force Components with Exponentlal Decay Constant (Coherence Function Model)

Figure 6-17: Varlation in the Ratlo of the Spectra of Lateral Force Components with Dimensionless Wave Number (Coherence Functlon Model)

Figure 8-18: Varlation in the Reduction of Along Wiave Force Spectrum with Exponentlal Decay Constant (Coherence Function Model)

Figure 6-19: Varlation In the Reduction of Along Wive Force

Spectrum with Dimenslonless Wavenumber (Coherence Functlon Model)

Figure 6-20: Varlation in the Reduction of Along Wive Force Spectrum, for Two Vertlcal Parallel Elements, with Exponentlal Decay Constant (Coherence Function Model)

Figure 6-21: Varlation In the Real Part of Along Wave Force Spectrum with Separation to Wave Length Ratlo (Coherence Function Model)

Figure 6-22: Varlation In the Real Part of Along Wave Force Spectrum with Separation to Wave Length Ratlo (Dlrectlonal Spectrum Model)

Figure 6-23: Varlation in the Real Part of Alone Wave Force Spectrum with Separation to Wave Length Ratlo (Comparison Between Three Models)

Figure 6-24: Varlation in the Absolute Value of Along Wave Force Spectrum with Separation to Wave Length Ratlo (Comparison Between Three Models)

Figure 6-25: Variation in the Approximation Ratio $R_{z_{o}}$ with Exponentlal Decay Constant (Coherence Function Model) 
Figure 6-26: Naplation in the Approximstion Ratlo $R_{\text {a }}$ ilin

Dimenslonless Wistenumber, Coherence Funcilon Model)

Figure 6-27: Vaplation In the Approximstion Ratio $R_{z}$ with

Dimenslonless Wavenumber, Comparlison of Both Models)

Figure 7-1: Ortshore Tower Idealization 183

Figure 7-2: Carteslan Coordinate System . . 184

Figure 8-1: Flxed Ortshore Tower lsed In the Exsmple 199

Figure 8-2: Member Numbering of the Tower 200

Figure 8-3: Member Numbering of the Tower (Conilnued) 201

Figure 8-4: Soll Shear Wave Veloclty Pronles 204

Figure 8-5: Varlation in Vatural Frequencles and Damping Ratlos of 206 the Tower with Soll Shear Wave Veloclty

Figure 8-6: Varlation in Natural Frequencles and Damping Ratlos of 211 the Tower with Plle Separation Ratio e/d

Figure 8-7: Varlation in the Flrst Niatural Frequency of the Tower 218

Figure 8-8: Peak Frequencles of Sea Surface Elevation Spectrum and 218 the Flrst Natural Frequencles of the Tower

Figure 8-9: Varlation In the First Modal Damplng Ratlo of the Tower with Deck Mass

Figure 8-10: Hydrodynamlc Damplng Ratlo for Different Soll Shear Tiave velocitles

Figure 8-11: Effect of Soll Shear Wave Veloclty on Tower Response to Waves

Figure 8-12: Top Node Response Spectra for Three Shear Wive

Velocitles $(\mathrm{C}=10 \mathrm{~m} / \mathrm{s})$

Figure 8-13: Top . Tode Response Spectra for Two Different Shear

Wave Velocltles ( $C=40 \mathrm{~m} / \mathrm{s}$ )

Figure 8-11: Tower Response Spectra for Three Soll Pronles

Figure 8-15: Erfect of Plle Soll Plle Interactlon on Tower Response

Spectrum for Three Dirferent Wind Speeds

Figure 8-16: Varlation In Hydrodynamle Damplng Ratlo with Mean Wind Speed

Figure 8-17: Varlation In Top Node Response with Mean Wind

Figure 8-18: Erfect of Exponentlal Decay Parameter on Tower 
Figure 8-19: 'Top Node Response Spectra for Two lislues of the

Exponenilal Decay-Parameter

Figure 8-20: Erfect of Deck Mass on Tower Response 


\section{List of Tables}

Table 81: Structural Propertles of the Tower Members 202

Table 8-2: Natural Frequencles and Damplng Ratlos of the Torer 208 Calculsted for Three Soll Pronles $(b=180 \mathrm{~m}$ 's. Dynamic Interaction Considered. Plle Separation Neglected)

Table 8-3: Natural Frequencles and Damplng Ratlos of the Tower

Calculated for Three Soll Pronles $\left(l=100 \mathrm{~m}, \mathrm{~s}, c_{/} / d=2.0\right.$.

Plte-Soll-Plle Interaction .ieglected)

Table 8-4: Ciatural Frequencles and Damplng Ratlos of the Tower

Calculated for Two Plle Separation Ratlos $(l=100 \mathrm{~m} / \mathrm{s}$.

Parabolle Soll Pronle. Plle-Soll-Plle Interaction . Veglected)

Table 8-5: Natural Frequencles and Damplng Ratios of the Tower

- Calculated with and without Interaction $(b=100 \mathrm{~m} / \mathrm{s}$. No

: Separation. Parabollc Soll Pronle)

Table 8-6: Natiral Frequencles and Damping Ratlos of the Tower

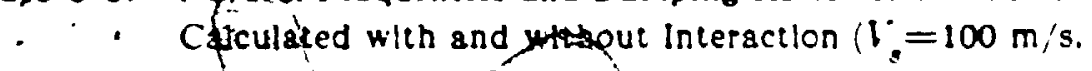

$\ldots e / \phi=2.0$. Parabof soll Pronle)

Table 8-7: Viftural Frequeriles gatbamplng Ratlos of the Tower Galculated for Stattc and Dynamle Interaction $(l=100$ $\mathrm{m} / \mathrm{s}$. No Gille Separation. Parabolle Soll Pronle)

Table 8-8: Firstrairal Frequencles and Ifodal Damplng Ratios Calculated for Three Soll Pronies $\left(V_{n}^{\circ}=100 \mathrm{~m} / \mathrm{s}\right.$. . No Plle Separation. Dynamic Plle-Soll-Plle Interacilon)

Table 8-8: Tower Response to Wave Forces and Hydrodynamlc 225 Dampling Ratlos for Different Wind Speeds Calculated Elther Veglecting or Considering Plle-Soll-Plle Interactlon ( $V_{\mathrm{s}}=100 \mathrm{~m} / \mathrm{s}$. Parabolle Soll Pronle) 


\section{Chapter One Introduction}

\subsection{General}

Orfshore structures are used for several purposes such as oll and. zas productlon. oceanographle resettch. navlgatlonal lighting and radar tracking. however, the vast majorlty are used for the nrst appllcation. Dwindling oll supply from onshore locatlons has accelerated offshore exploratlon and production actlvitles. Orfshote platforms are Installed in ever increasing water depths and extremely hostlle environments, such as those encountered in the Vorth ses. These conditions introduce considerable dimcultles in deslgn and Incraase the potentlal loss in human life and capltal in case of a majö fallure. Accordingly. extensive research programmes have been undertaken during the last four decades to understand all aspects of behavlour of offshore structures.

Two maln factors are cruclal in assessing the rellabllity of any structure: strength and loadleg. The supporting foundation. whlch conslsts of plles for most offshore structures. Is one of the more Important parameters that defne the strength of an oitrshore stifucture. Prediction of the axial capacity of the supporting pules apd assessing thelp drivabllity using a certain hammer system are malor probletims escouniered, in oftshore phing. Due to adverse weather conations and the necesslty of ardering equlpment ahead of time. plle drivabllity preptction is assigned speclal importance in affshore construction. The one dimenstonal wave equation analysls [1] is widely used in studying the plle drivabillty problem. Yet, offshore plles are extremely expenslve and rurther Investigatlons of their behavlour are needed.

Soll-structure Interaction plays an Important role in predlcting the response 
of offshore structures to environmentsl loads, whlch are ma!nly dynamle. it alters the dynamte propertles of the structure and may increase or decrease the response depending on the relatlonshlp of the fundamental natural frequency to the dominant exclting frequency. Random wave forces on oftshore towers are usually evaluated using the directlonal spectrum of sea surface elevation. This representation does not take Into account the lack of spatlal correlation which may be assoclated with fully developed random waves.

\subsection{Objectives of the Study and Organization of the Thesis}

This study ts divided into two main parts. The nrst pari deals with the plle drivabllity analysls. The second part is concerned with the response of nxed offshore structures to random wave forces. The objectlves of the nrst part are:

- 1. To Improve on the one dimenslonal wave equation analysts of plle drivabllity by accounting. In a rattonal way, for wave propagation in the soll and by formulating parameters related to standard soll. characterlstics.

2. To formulate a three dimenslonal innlte element analysls with sultable transmitting boundarles and compare th results to those of the one dimenslonal analysls in order to lllustrate the advantages, and . llmitstions of both models.

In the second part of the study, the snalysls is llmited to the jacket type platforms or towers. and the objectlves are:

1. To examine the eftect of dynamic plle-soll-plle Interaction on the response of nxed offshore towers to random wave forces.

2. To establish an approach for evaluating random wave loads on offshore towers which takes into sccount the lack of spailas correlation of random waves and allow for directlonal effects.

Chapter 2 glves brlet revlew of different types of ofrshore structures, maln sources of environmental loads and the Important parameters that govern the behavlour of these structures. In Chapter 3. the one dimenslonal wave equation 



\section{Chapter Two Review of Offshore Structures}

\subsection{Types of Offshore Structures}

Currently, about $20 \sigma_{c}$ of the world oll production is extracted from onshore reservolrs. Most of these reservolrs are located in the conilnental shelves where the average water depth is about $120 \mathrm{~m}$. The vast majorlty of the early ofrshore structures are of the steel Jacket (template) type whlch are Installed in water depths. less than $100 \mathrm{~m}$. These template structures are nxed at the sea bed and are characterlzed by having short fundamental perlods for high fundamental frequencles) In the pange of 1 to 5 seconds. Thelr natural perlods, thus fall below those of the waves with slgnincant energy content. Linder such conditions, the response to extreme waves is malnly statlc with little dynamlc magnincation. These waves, typlcally, have perlods ranglng from 6 seconds to 25 seconds with the longer perlod waves having hlgher energy.

As new resources are dlscovered in deeper water and more severe environmenis, extrapolation of the conventional Jacket platforms becomes unfeaslble for two reasons. First, the requlred barge capactules for transportation and erectlon of these towers places a constralnt on thelr slze. Secondly and more Important is the relationship of the natural perlods to the perlods of waves with hlgh energy content. The natural perlod increases with water depth untll, for deep water. It lles withln the peak wave energy zone whlch léads to large dynamlc magnincation. For deep water, an alternatlve for the nxed platforms are the compllant structures whlch have fundamental perlods well above the highest peak wave perlods. In what follows, four maln types of ofrshore structures are brleny descrlbed. 


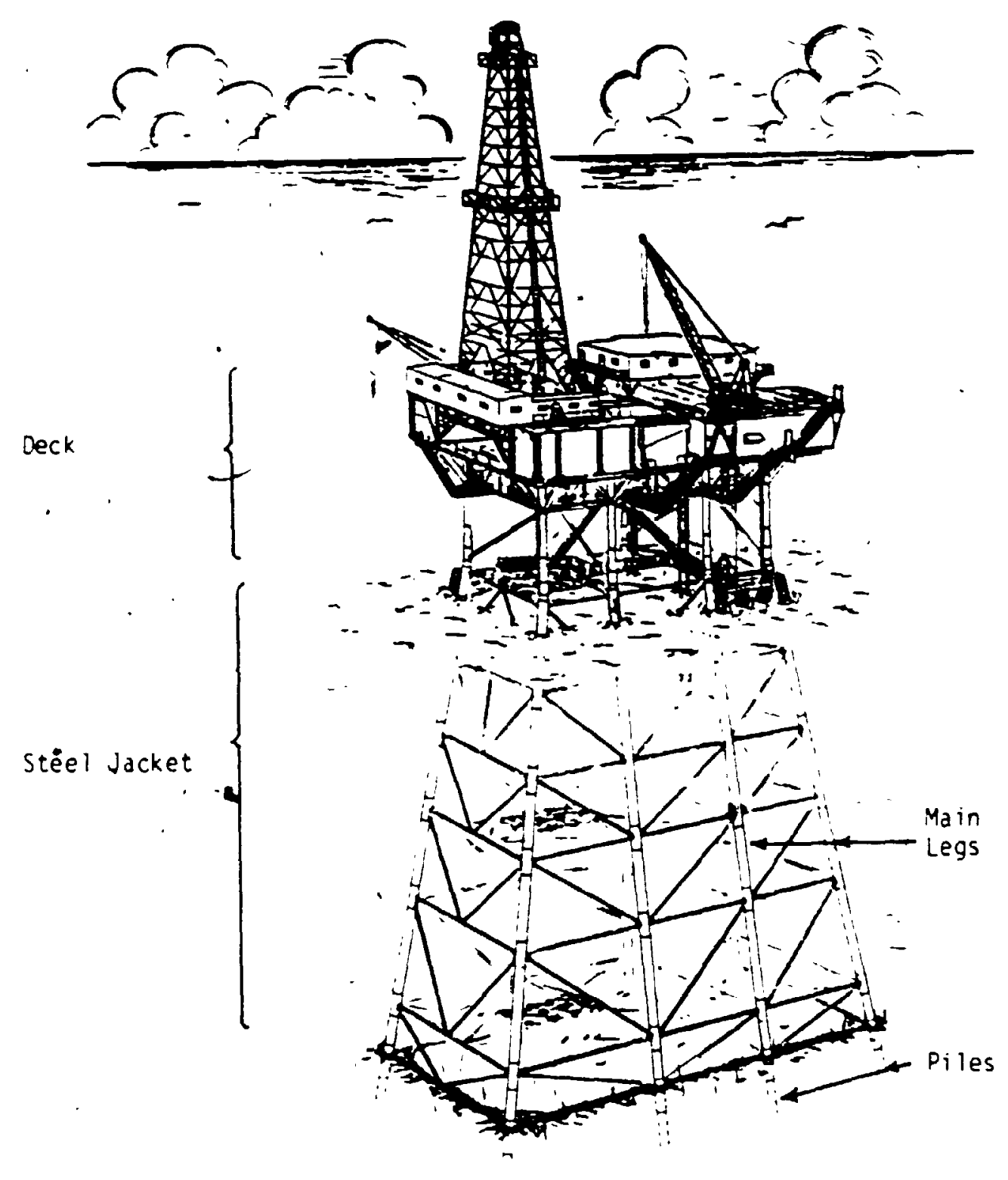

Figure 2-1; Steel Jacket Offshore Platform. Dawson [183) 
1) Steel Jacket (Template) Platform: Thls is a spsce frame that extends from the sea bottom to above the uster surface. Fig. 2.1 Plles are driter through the legs of the jacket Into the sea Moor. These transfer vertical loads io the soll and $n x$ the structure in place agalnst lateral loads from wind. 'waves, curfents and collislons with shlps or lcebergs. The bending stiffness of the plles contrlbute to the lateral stirfness of the structure and thus they are rigldly connected to the structure and are placed as far away from each other as posstble. Template iype platforms are sultable for water depths up to $300 \mathrm{~m}$. The tallest such structure is the Cognac platform standing $\ln 312 \mathrm{~m}$ or water.

2)Tenaion Leg Platform (TLP): It consists of a noating hull of a large slze whlch is pulled down by highly tensloned vertlcal tethers. Flg. 2.2. Some degree of lateral motion is allowed but the hull is pulled down so far that the tethers never go slack even in the trough of extreme waves. One advantage of the TLP is the relative insensitivity of lts cost to water depth. Tension leg platforms have perlods above 20 seconds and appear to be advantageous to other systems for water depths greater than $500 \mathrm{~m}$. The Hutton platform. constructed In $148 \mathrm{~m}$ of water, is the only TLP constructed so far.

The TLP foundation, which may consist of plles or gravity type footings. serves as an anchor to $\mathrm{nx}$ the tethers to the bottom of the sea. In case of plled foundatlons, a base template is nrst positloned at the sea bed then plles are driven through sleeves in the template and grouted in these sleeves. The foundation loading conslsts of the dead load and a constant tenslle force due to - buoyancy of the hull In addltion to cyclic wave loads. Experlmental studles have shown that cyclle loading can cause significant degradation in the soll transfer capabllity and a marked decrease in the soll stirfness.

3)Guyed Tower PLatforme It conslsts of a slender steel tower held 


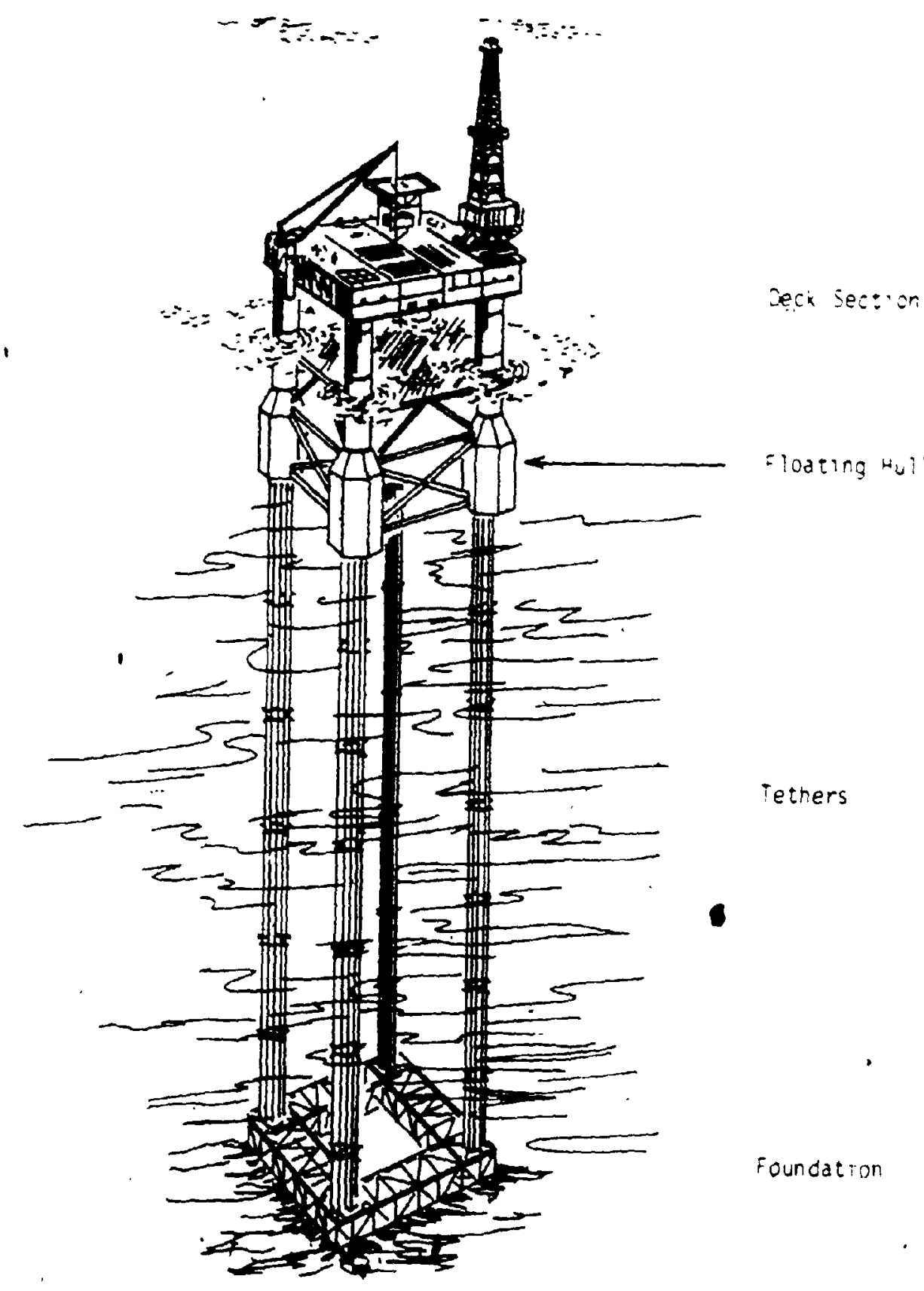

Figure 2-2: Schematle of a Tension Leg Platform. Dawson ;183! ! 
ufight by anchor cables wlih clump welghts resting on the sea bed. Fig. 2.3 Inder evireme waves, these clump welghts wlll gradually llrt and allow the cowe: to :Itt. The guyed tomer. thus acts as a towet plnned at lis base by plle foundations. Since thls deslgn uncouples the bending stiffness of the plles from the iateral stirfness of the tower. plles are not rigldly connected to the cower at the base but are plnned.

Lena guyed tower is the only such platform and was installed in 1984 in 305 $\mathrm{m}$ or water. Guyed towers. Ilke TLP. are compllsnt structures with long natura! perlods and are allowed to more laterally. thus resisting the wave loads by thelr Inertla rather than their stimness. It is expected that guyed towers will be cost effectlve in the range of 350 to $450 \mathrm{~m}$ of water [3].

4)Gravity Platforms: These are concrete structures with a large diameter base resting on the sea bed. The base usually conslsts of cyllndrtcal cells of which only a few extend above mean water level to support the deck sectlon which is made of steel modules. Fig. 2.4. Gravity base structures do not need to be anchored to the sea bed as they are stable under thelr immense welght. The cyllndrical cells are used for the storage of crude oll and delsel fuel. Tankers can load crude oll directly from the platform. thus saving the cost of extending a plpellne to an onshore facllty. The largest gravity type structure is the Statfjord B platform whlch welghs 899.000 ton and is bullt $\ln 144 \mathrm{~m}$ of water.

\subsection{Environmental Loads}

The maln sources of environmental loads on offshore structures are waves. currents, wind, Ice, earthquakes and mudslldes. Some of these loads are brlefly discussed in the following.

1)Wave Loads:These can elther be described by deterministlc or storhasitc methods. In the deterministlc approach. a design wave is selected based upon a 


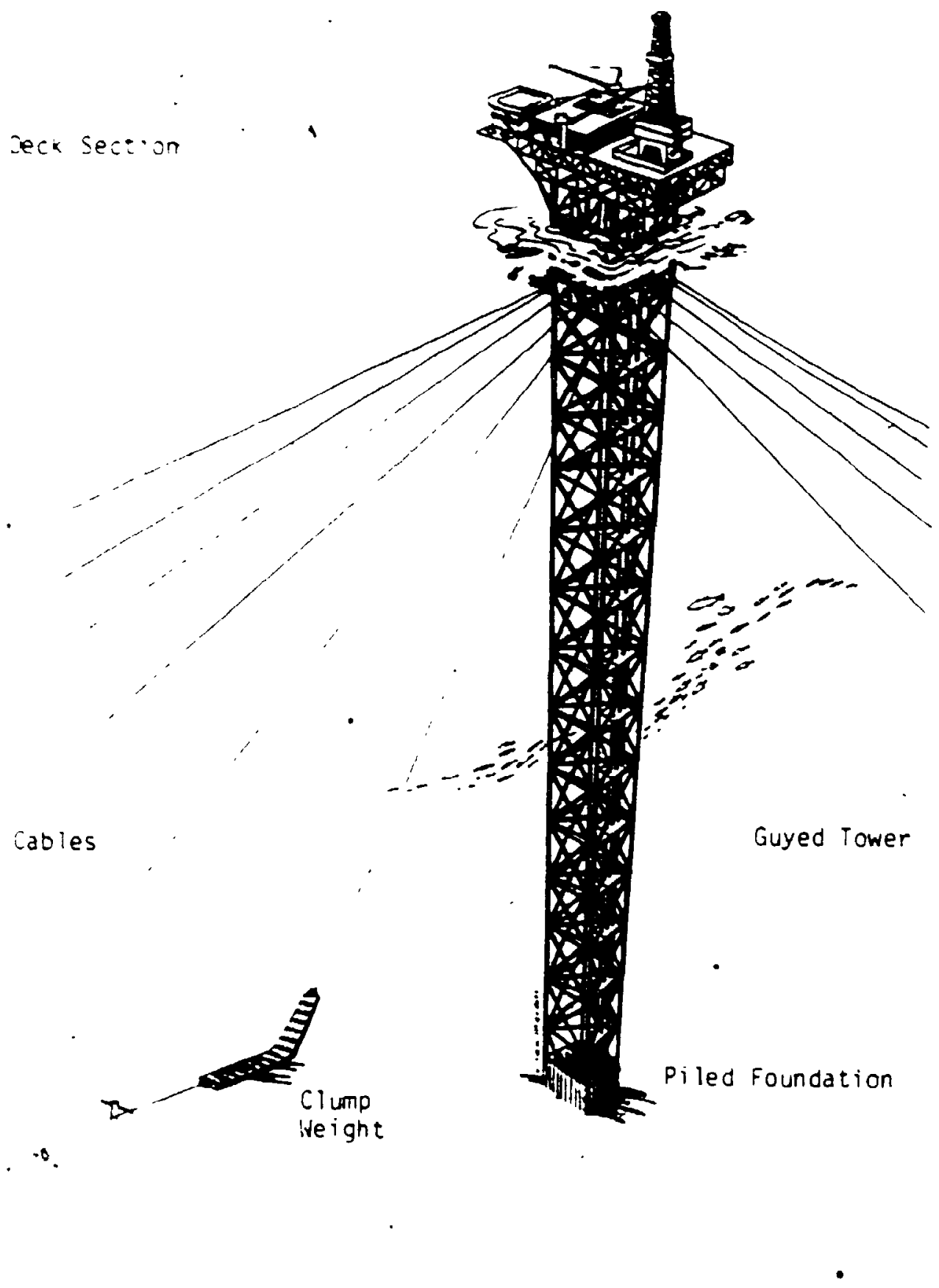

Figure 2-3: Guyed Tower Platform. Dawson [183! 


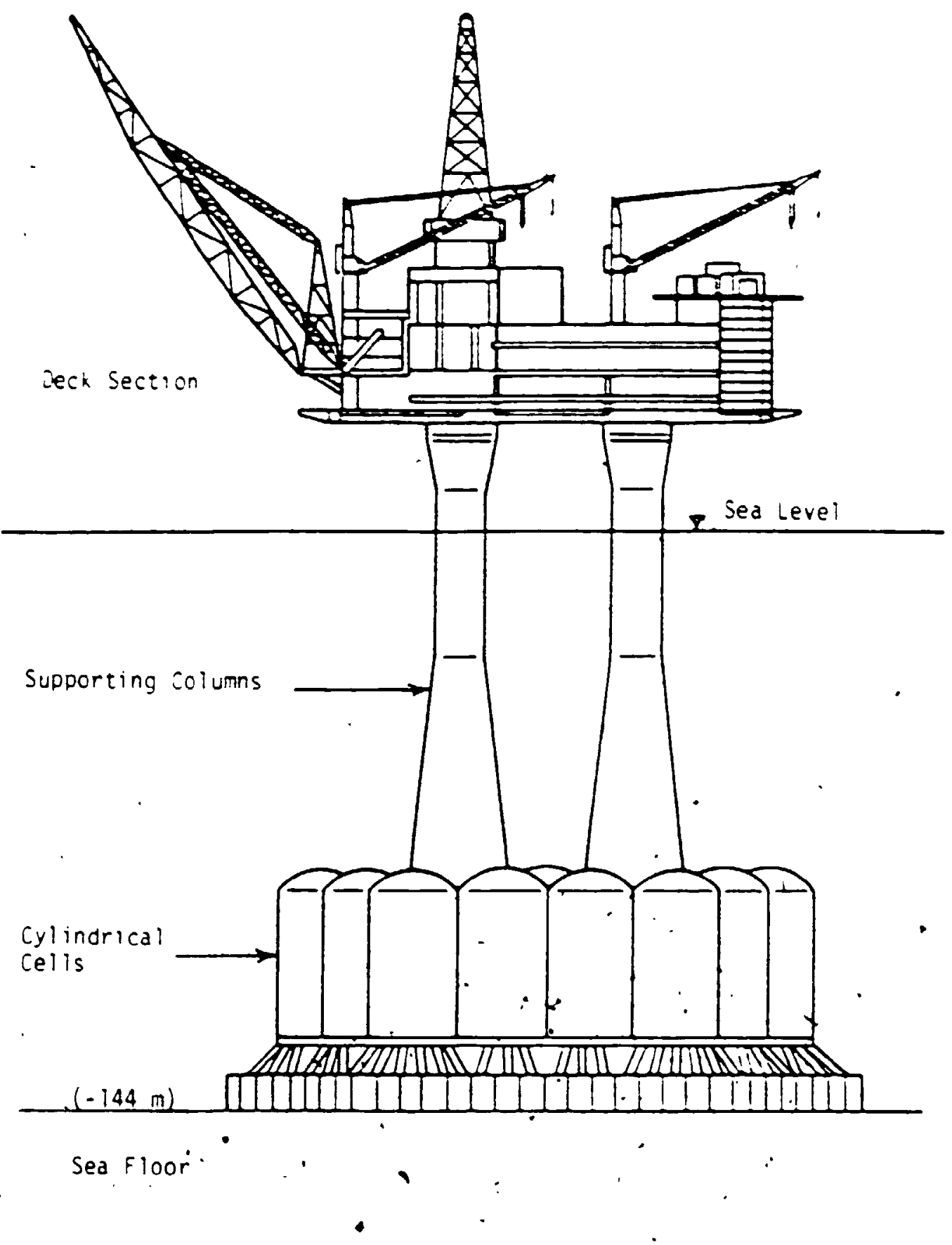

Figure 2-4: Statford B Concrete Gravlty Platform

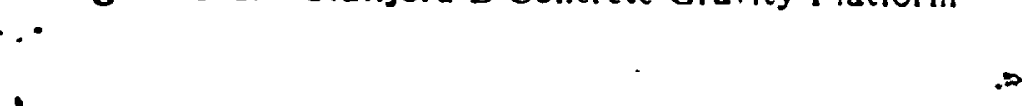





\section{Chapter Three \\ One Dimensional Analysis of Pile Driving}

\subsection{Introduction}

Theoretical predtction and analysls of plle driving records serve tho purposes. On one hand, plle drivabllity and penetration can be assessed by determining the permanent set per blow (blow count) for a certaln hammer system. On the other hand. driving records can be used to evaluate the plle bearing capacliy.

Early attempts for plle driving analysls resulted in the "Dynamle Plle Formulae; whlch are used to determine the plle bearlng capactty by relating it to certaln parsmeters of the drlving process. All or these formulae are empirical and consequently apply only to certain types of plles or soll condltions. These formulae. however can produce misleading results owing to the poor representation of the time dependent aspects of the problem.

Smltb [1]. In 1960, formulated the plle driving probtem in terms of the one dimenslonal wave equation and introduced a numerical solution to the problem using a nnlle difference scheme. His solution caught wide attentlon and recelved acceptance because it offered the nrst rattonal approach for studying the many subtletles of the plle driving process. Smlth introduced two non-tradthlonal.soll mechantes parameters in hts model. These parameters are the quake and a damping constant. The quake is.defined as the maximum elastle deformation of the soll adjacent to the pile before plastlc deformation occurs. Both of these parameters can not be evaluated from laboratory experlments and have to be - determined emplrically by correlating the wave equation results with load tests and plle drlving records.

- SInce then, most research has been directed towards renning the solution 
Introduced by Smith. Because the method is mathematlcally sound. as far as wave propagatlon Inslde the plle is concerned. such rennements have been itmited to suggesting better alternatives of the difrerence scheme to be used i6; of more sophlstlcated theologlcal models [7.8]. The wave equation analysis has also been used to study the influence of plle plugging $[9]$ and resldual forces on plle drlvabllity and beaping capaclty $\lceil 10 !$.

Recent research at Case Western Reserve Unlverslty resulted in the Case Method Bearing Capacity Equation \{11\}. Lising thls equation. the bearing capactty of a plle is evaluated by relating th to certaln values of the veloclty and force ilme records measured during driving. It is important therefore to obtain a reallstlc prediction of both : the permanent set and the time historles of the pertinent quantltes. In this chapter, the representation of the soll resistance during driving is improved by accounting expllclty for wave propagation in the soll. This is accompllshed using the plane straln soll reactlons ;12!. These reactlons represent the resistance of a soll continuum to the harmonic vibration of an Innnitely long rigld cyllnder under the plane styaln assumption. Soll shear modulus. Polsson's ratlo and soll material damping ratlo are the only parameters necessary to evaluate the plane strain soll reactlons. These three parameters can be evaluated from conventlonal laboratory experlments. 'Results of the wave equation analysis obtalned using the proposed, model are then compared. with those obtalned using the original Smith model.

\subsection{Wave Equation in Pile Driving Analysis .}

\subsubsection{One Dimensional Wave Equation}

Isaacs [13]. In 1931, was the nrst to polnt out that wave actlon occurs during plle driving. In 1938. Fox publlshed the nrst solution to the wave equation applled to plle driving, but due to computation limitatlons he was compelled to make a number of simplirying assumptlons whlch marted his solution [1]. 
When an elastlc rod ts subjected to a suddenly applled axlal load. a stress wave is generated whlch travels away from the polnt of load appllcation. For a slender rod, the plane stress approximation holds and the wave is consldered as a one dimenslonal stress wave. With the lateral straln and materlal hysterests neglected, the governing differential equation is the classical wave equation

$$
\frac{\partial^{2} u}{\partial t^{2}}=t_{p}^{.2} \frac{\partial^{2} u}{\partial x^{2}}
$$

Where $u=u(x . t)$ is the axlal displacement of a partcle at time $t$. whose origtnal position is $x, v_{p}=\sqrt{E / \rho}$ is the one dimenstonal primary wave veloclty and $E$ and $\rho$ are the Young's modulus and mass denslty of the rod materlat, respectively. The solution to thls equation is well known e.g. $[14]$, and is glven by

$$
u(x, t)=g\left(l_{p}^{\prime} t+x\right)+h\left(l_{p}^{\prime} t-x\right)
$$

where $g$ and $h$ are arbltrary functions which depend on the Inltlal disturbance. Waves travellng in the postlive $x$-direction are represented by $h\left(V_{p} t-x\right)$ whlle those traveling in the negative $x$-direction are represented by $g\left(l_{p}^{*} t+x\right)$.

During plle drlving. the vlbrating plle meets soll reslstance and on additional tern has to be added to the wave equation to represent the soll reslapce. The governing equation is then written as

$$
\frac{\partial^{2} u}{\partial t^{2}}=V_{p}^{2} \frac{\partial^{2} u}{\partial x^{2}} \pm \frac{R}{\rho A}
$$

where $R$ is the soll reslatance per unlt length of the plle and $A$ is the cross sectlon area of the plle. $\pm R$ Indlcates that the soll resistance always opposes the motion. The solution of Eq. 3.3 depends on the nature of soll resistance.

Dynamlc soll resistance differs from the statlc one in two maln aspects. One Is the presence of Inertla forces in the vlbrating soll mass, the other is the energy dissipation assoclated with wave propagation in the soll contlnuum. Soll 
resistance can be spllt Into a rate of deformaton Independent part (stirness) and a rate of deformation dependent part (damplng). Both parts of soll resistance are nonlinear $[\mathbf{7}, 15]$ and Eq. -3.3 is thus a second order nonllnear partlal differentlal equation. An analytical solution to such an equation is dimcult and numerical methods such as nnite elemrents and nnlte differences are resorted to. The method suggested by Smlth represents a nnlte difference solution to Eq. 3.3.

\subsubsection{Smith Model}

Only a brief description of the Smith model is glven below as it is described In rull detall elsewhere $[1,18]$. The, plle-hammer system conslsts of the hammer ram, capblock, plle cap, cushlon and the plle, Fig. 3.1. The ram and plle cap are Idealized as rigld masses whlle the cap block and cushlon are consldered as massless springs. The plle is Ideallzed by a set of dicrete elements. each ascribed a weight $W_{m}$ and a spring $S_{m}$. Soll resistance ts assigned to each of these elements and is spllt into a rate (or deformation) dependent part. Ideallzed as a dashpot and a rate Independent part, Ideallzed as a spring.

Lnder the effect of the hammer blow, the plle elements move and so do the adjacent soll particles. Soll deformation grows elastically up to a certaln displacement where sllp occurs and the soll offers a constant reslstance to the plle . elements, Fig. 3.2. On reversal of the direction of velocity. the soll deforms elastlcally untll a full reversal has taken place where sllp occurs in the opposite direction. As the plle element reaches the maximum displacement under the effect of the blow, elastlc forces of the soll push it upwards and the element vibrates for a whlle before It settles In a new equllibrium position. The plastlc displacement of the plle tlp (permanent penetration) is called the set. Fig. 3.3. The spring representing soll stimness per unit length of plle-soll interface is glven by

$$
k=R_{\mathrm{u}} / Q
$$





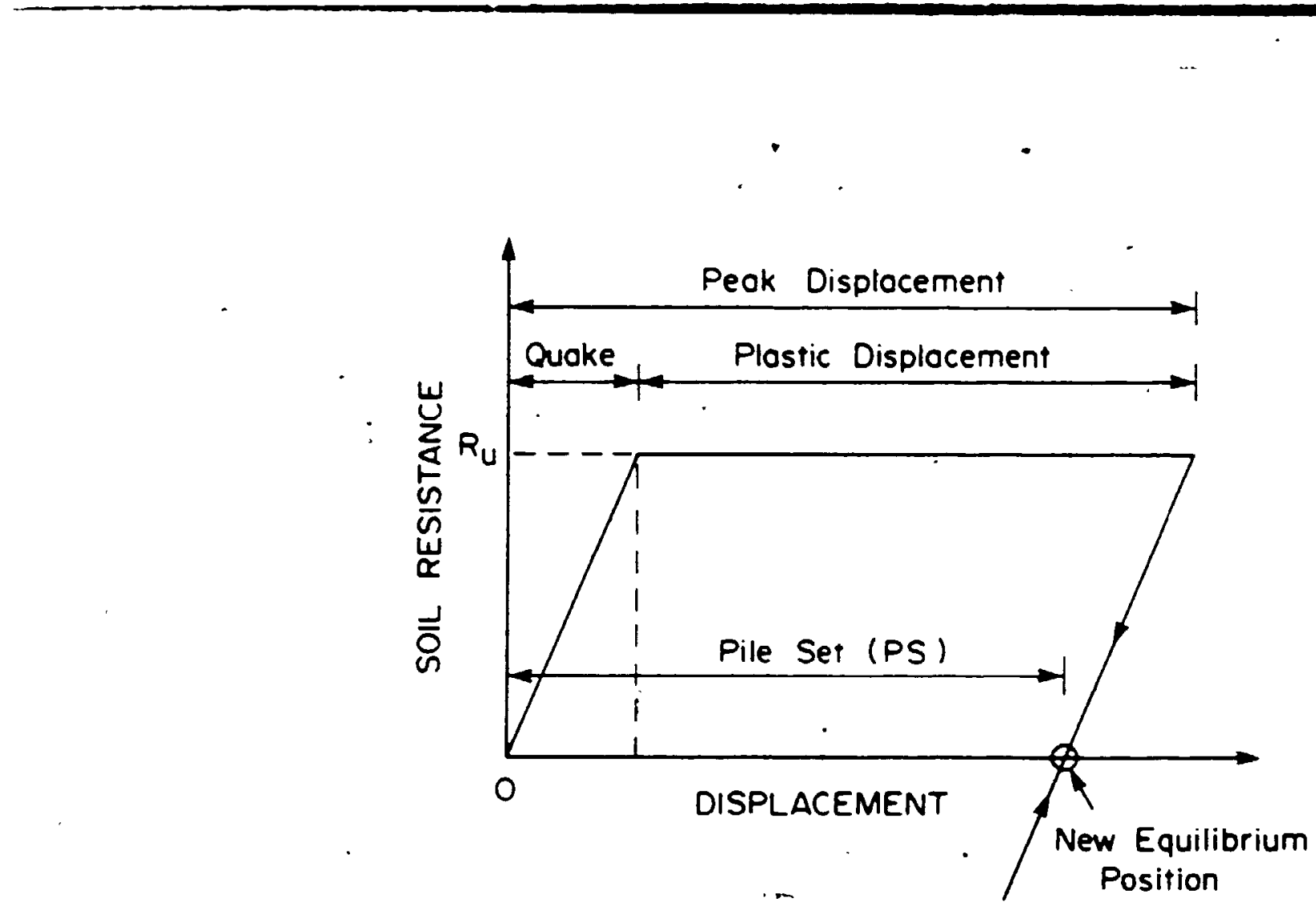

Figure 3-2: Force Displacement Relatlonshlp of Soll Spring

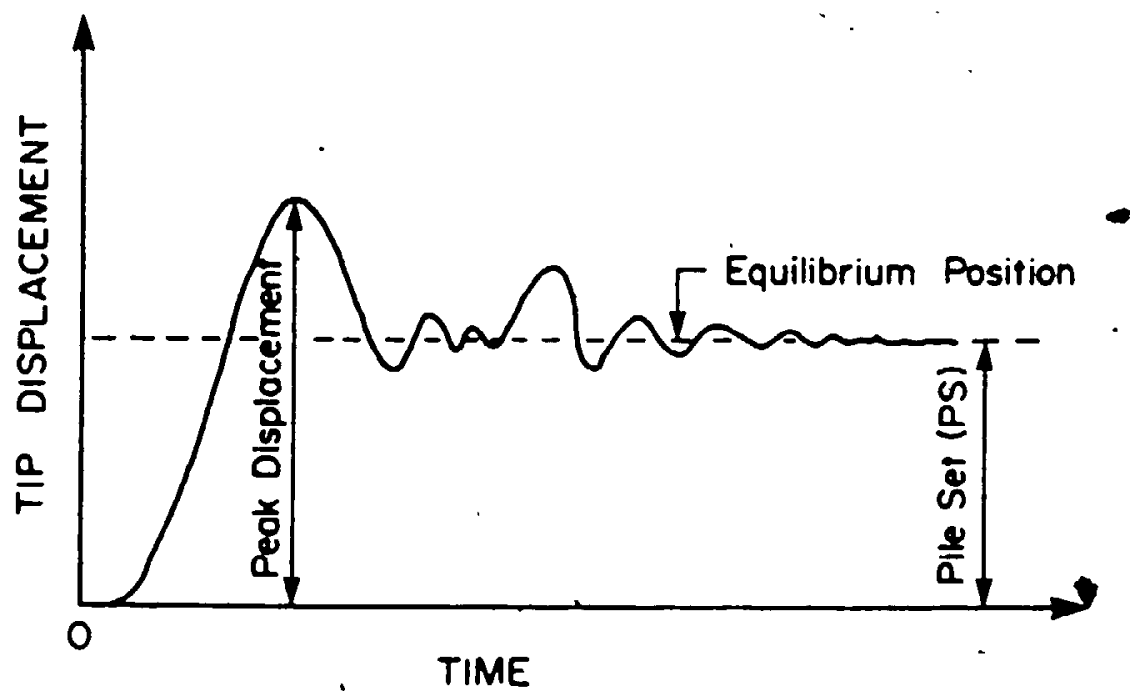

Figure 3-3: Vibratlon of Plle Tip Around ąn Equllibrlum Posltion 



During plle driving. the soll around the plle is subjected to elastle stresses which Increase untll they are equal to the shear strength of the soll causing ultimate fallute of the soll in the form of plastle now As a result of this now and plastlc deformatlons, the soll is disturbed and remoulded causing excess pore water pressure to be generated. Consequently, shear strength of the soll around the plle is signincantly less than that of the undisturbed soll. This reduction of the shear strength has been recommended by Iyayverglya 22: and reported by Roy et al. [23] based on full scale measurements on instrumented piles in a sensltive clay.

From the prevlous discusslon, the following conclusions are drawn:

1. The Case method for plle driving analysls is sulted only for situations where plle instrumentation is possible and can not glve predictlons for drlvabllity or bearing capacliy before the plles are driven in.

2. Athough the Smlth model Introduced a fundamental Improvement in understanding the plle driving process. It suffers from the limitation that the necessary parameters are empirical.

3. The need arises to Improve the Smith model by Introducing parameters based on traditional soll characteristics that can be rellably evaluated.

\subsection{Proposed Model for Soil Resistance}

In the current study, soll reslstance to the vibrating plle is modelled using the plane straln soll reactlons. The mathematical model used for formulating and solving the equatlons of motlon is the nnite difference model developed by Smlth.

\subsubsection{Plane Strain Soil Reactiong}

- As the plle vlbrates, forces are traosfered through the plle-soll interface causing the soll masg around the plle to vibrate as well. During this vibration. energy is disstpated through radiation of elastlc waves (geometeric damplng) and by converslon Into heat due to hysteresis (materlal damplng). A proper 



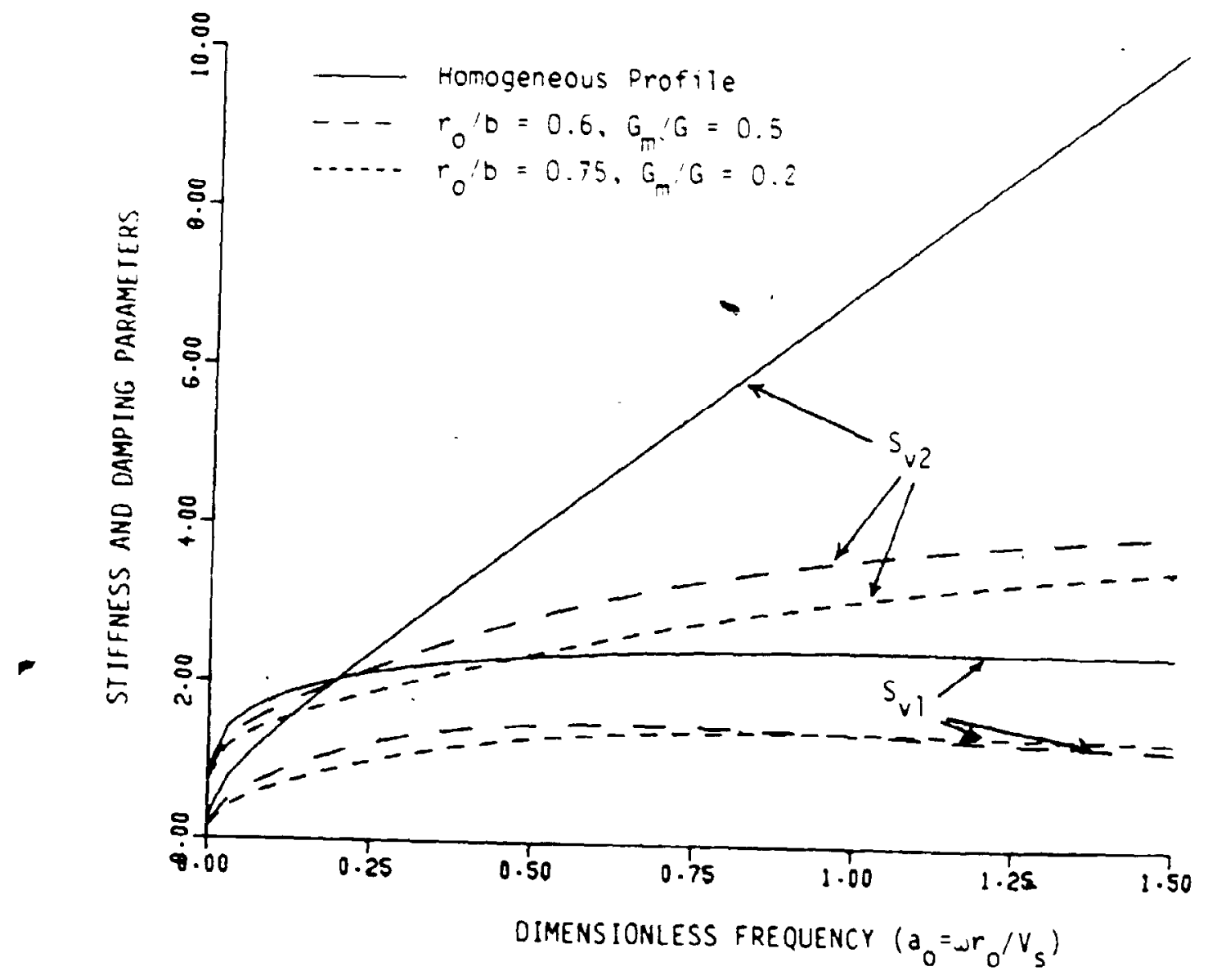

Figure 3-4: Plane Straln Vertlcal Reactions for the Composite Medlum 


\subsubsection{Soil Stiffness and Damping}

In thls study. the spitng representing soll simness along the plle shart is modelled as

$$
k=G S_{i 1}
$$

and that at the plle thp is alven by

$$
k=G_{0} C_{: 1}
$$

In Eq. 3.16. $C_{n 1}$ is the real part of the viscoelastlc half space reaction to a vibrating rlgld massless disk [20.. A blllnear soll spring. Fig. 3.2. Is also assumed In the proposed model. The elastle llmit of the soll reslstance may be determined using elther of the following criterla

1. Assuming a value for the quake as in the original Smith model. In this case, the ultimate resistance is $R_{u}=G S_{i 1} Q$.

2. Assuming a value for the ultimate resistance $R_{u}$. In this case, the quake value is $Q=R_{u} / G S_{t 11}$.

These two crlterla are used to analyse the drivablity of an example plle and the resuils are compared in Section 3.5 .

The rate dependent part of the resistance is modelled by a viscous dashpot whose magnitude, for the plle shar, is

$$
c=G S_{t 2} / \omega
$$

and for the plle tlp is

$$
c=G_{0} C_{12} / \omega
$$

In Eq. 3.18. $C_{12}$ is the Iroaginary part of the viscoelastic half space reaction to a vibratlng rigld massless dise [26].

Before sllppage occurs. the plle and the surrounding soll are stlll in contact and vibration of the soll mass provides radlation damplng to the plle motion. Accordingly, the values of the parameters $S_{v 1}$ and $S_{12}$ in Eqs. 3.15 and 3.17 . respectlvely. should be those for a horlzontally homogeneous medlum. However. the stresses In the soll near the plle are hlgh and the soll around the plle has been 
disturbed under the effect of prevlous hammer blous. Thus. It Is reaconalit iv allow for a weakened zone with a reduced shear modulus around the plle shafi. even before sllppage. During plastic deformation sllppage. the bond between the plle and the surrounding soll breaks and each of them moves independen:ly excep: for the Interconnecting frictional force betueer the iso. Radiation damping during sllppage thus depends on the veloclit of the adjacen! soll particles and not that of the plle. Soll reslstance to plle motion during slippage would be best modelled by inis irlcilonal force if reallstic values for the friction can be estimated. Infortunately. systematlc and rellable measurements of this force are not yet avallable. In thls study, the soll stirness and damplng parameters for the plle shan, $S_{1,1}$ and $S_{12}$, respéctlvely, are taken to be those or the composite medlum before and during slippage. Acrordingly, the total soli reslstance at the plle shan is glven by

$$
R_{t}= \begin{cases}\left(G S_{1,1}\right) D+\left(G S_{t-2}\right) & D<Q \\ \left.\left(G S_{t 1}\right) Q+\left(G S_{12}\right)^{\circ}\right) & D \geq Q\end{cases}
$$

and for the plle ulp is glven by

$$
R_{t}^{\prime}= \begin{cases}\left(G r_{0} C_{i+1}\right) D+\left(G r_{0} C_{i 2} / \omega^{\prime}\right) l & D<Q \\ \left(G r_{0} C_{i \cdot 1}\right) Q+\left(G r_{0} C_{i 2} / \nu^{\prime}\right) l & D \geq Q\end{cases}
$$

\subsection{Example}

The following propertles are assumed for the soli-hammer-plle system

Hammer and capblock

Hammer welght

Impact veloclty

Capblock dlameter

Capblock helght

Young's modulus of capblock

coemclent of restltution of capblock

Weight of plle cap

Plle
$75 \mathrm{KN}$

$5 \mathrm{~m} / \mathrm{sec}$

$0.72 \mathrm{~m}$

$0.18 \mathrm{~m}$

$3.1 \times 10^{8} \mathrm{~Pa}$

0.8

$31.5 \mathrm{K.}$

$1.524 \mathrm{~m}$

$7700 \mathrm{~kg} / \mathrm{m}^{3}$ 
Wall thlckness

Total length $=$ embedded length

Young's modulus

Soll

$$
J_{p}
$$

Density

Quake

Polsson's ratlo
$0.032 \mathrm{~m}$

$20 \mathrm{~m}$

$2 \times 10^{11} \times \mathrm{m}^{2}$

$0.492 \mathrm{~m} / \mathrm{ses}$

$0.164 \mathrm{~m}$ iser

$1800 \mathrm{~kg} \cdot \mathrm{m}^{3}$

$2.5 \times 10^{-.1} \mathrm{~m}$

0.25

A numerlcal study has shown that the system Is stahle for $\Delta i \leq 2\rangle 10^{-}$' sec. accordingly. It was chosen to be $2 \times 10^{-1}$ sec. For the smith mudel. ine soll resistance Is calculated from Eq. 3.8 and the ultimate static resistance per unlt length_at the plle shaft is evaluated from

$$
R_{u}=\alpha \pi d C_{v}
$$

and for the plle tip

$$
R_{u}^{\prime}=\pi \frac{d^{2}}{4} \cdot V_{d} C_{u}
$$

In Eqs. 3.21 and 3.22, $C_{u}$ is the soll undralned shear strength. $\alpha$ is a reduction factor to represent the reduction in ultimate soll resistance during driving. $d$ is the phe dlameter and $N_{d}$ is the bearing capacliy factor assigned here the numerlcal value of 9 . For the proposed model, the reduction in shear modulus in the weakened zone is taken to be equal to a for the sake of comparison with the Smith model, l.e.

$$
G_{m} / G=\alpha
$$

The real part of the viscoelastlc half space reaction to a rigld massless disc varles mildly with frequency whlle $C_{t_{2}} / \omega$ is almost frequency independent. The elastlc soll propertles needed to evaluate the parameters for the proposed model are establlshed from the following relatlonshlp

$$
E=\lambda C_{i}
$$

where $E$ is the soll Young's modulus and $\lambda$ ranges between 500 and 1000 . 



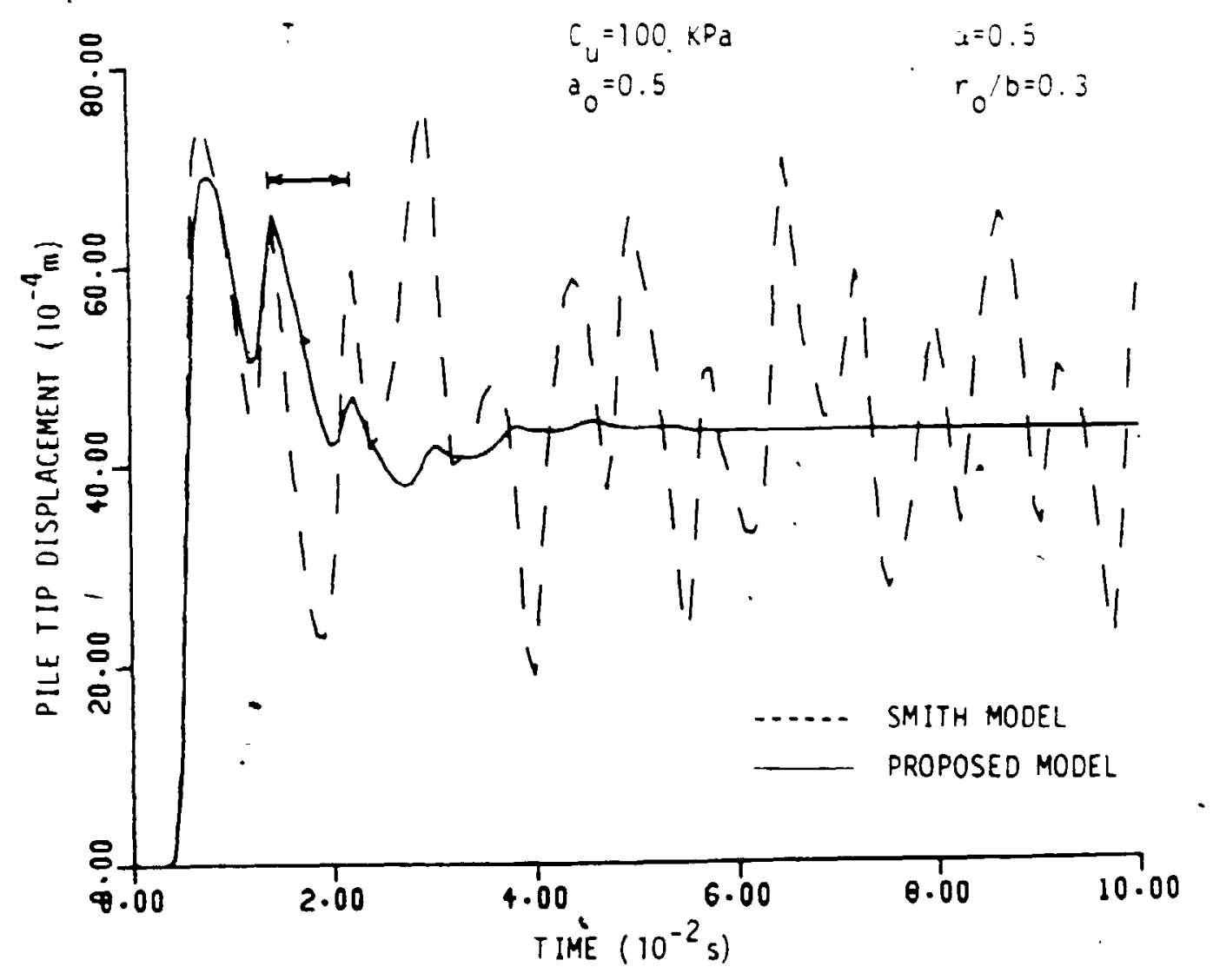

Figure 3-5: Comparison of Plle TIp Displacements for Two Models 


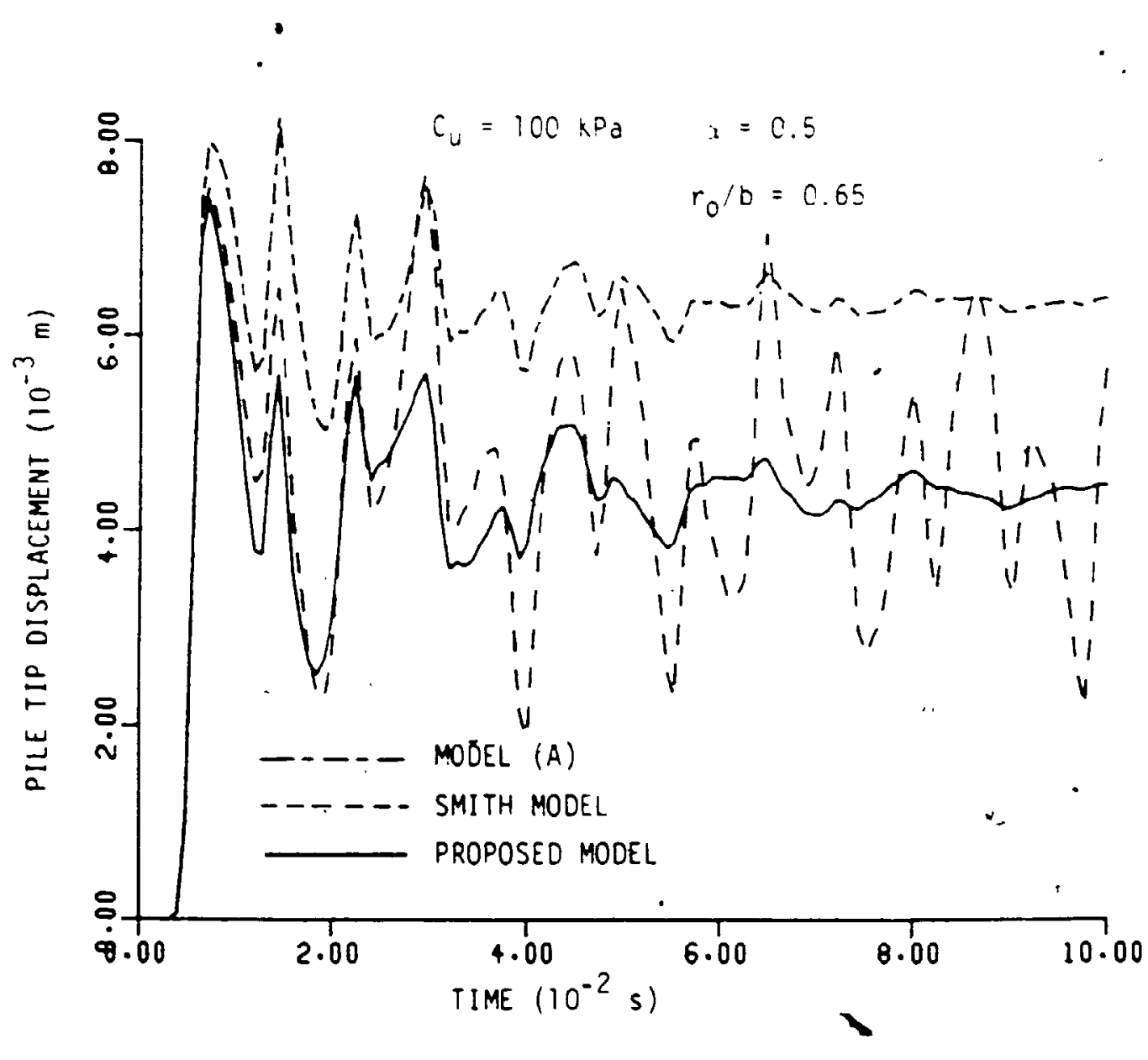

Figure 3-6: Comparison of Plle TIp Dlsplacements for Three Models 


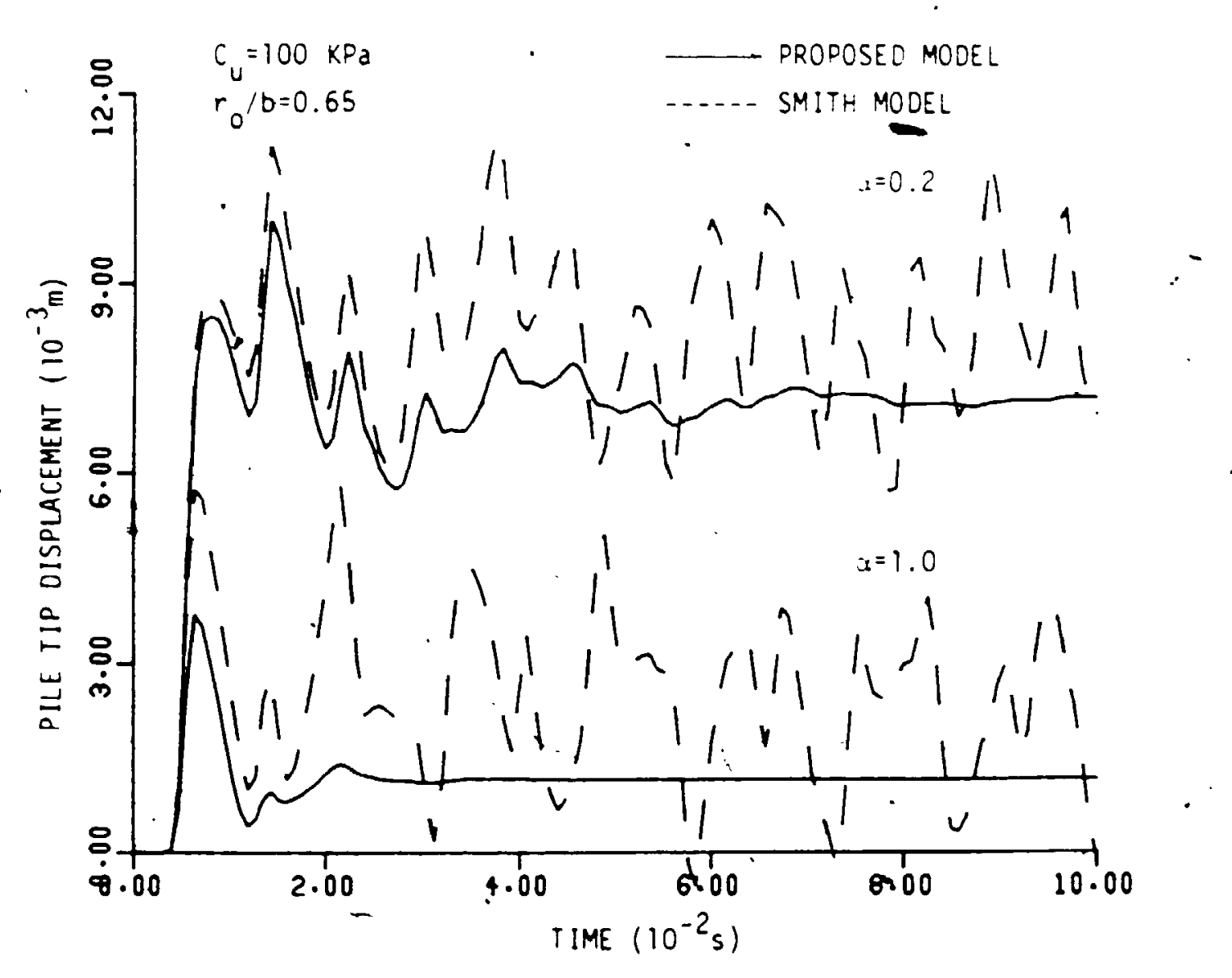

Figure 3-7: Plle TIp Displacements. for Two Interface Conditlons 



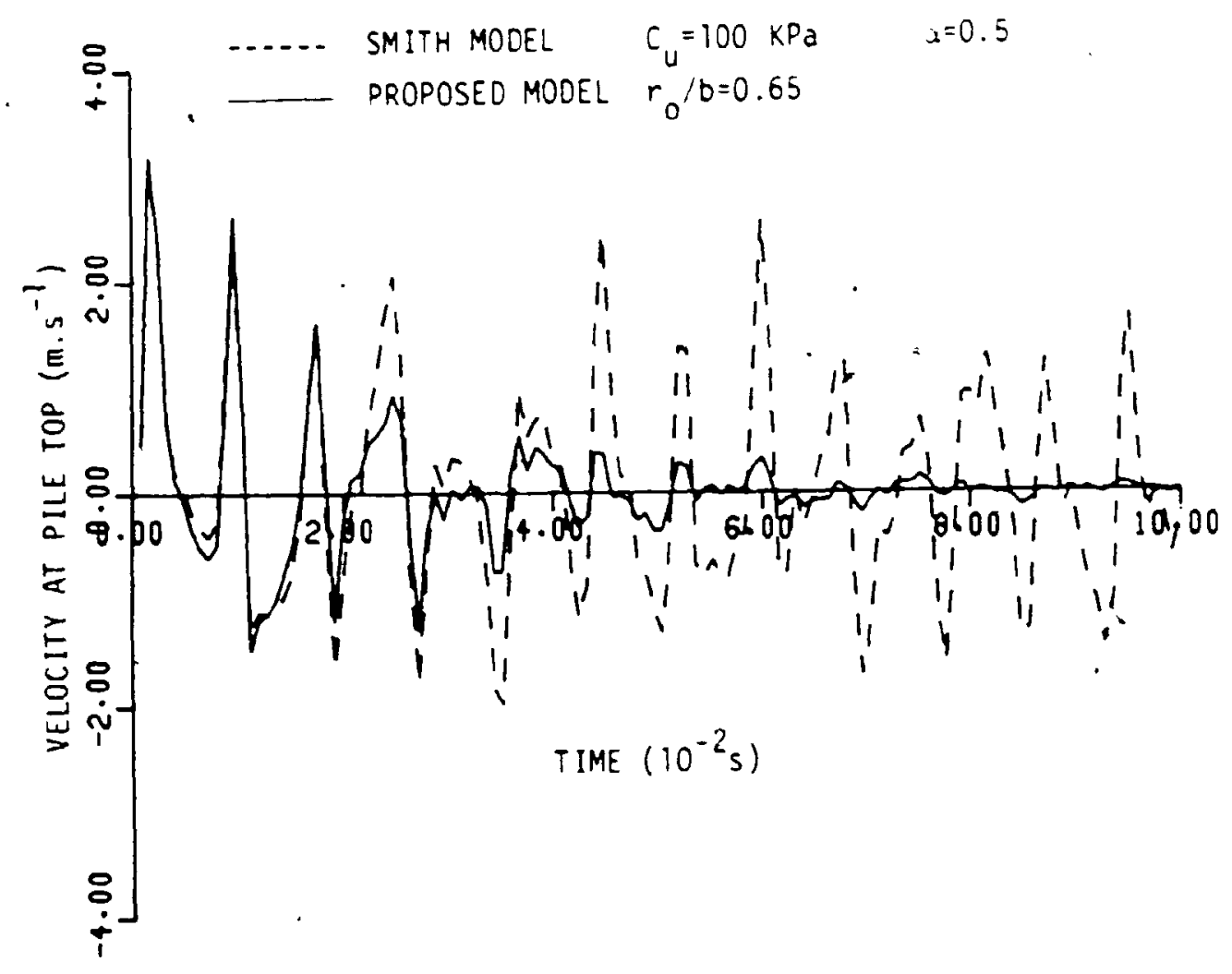

Figure 3-8: Time History of Veloclty at Plle Top $(\alpha=0.5$ and $C_{u}=100 \mathrm{KPa}$ ) 


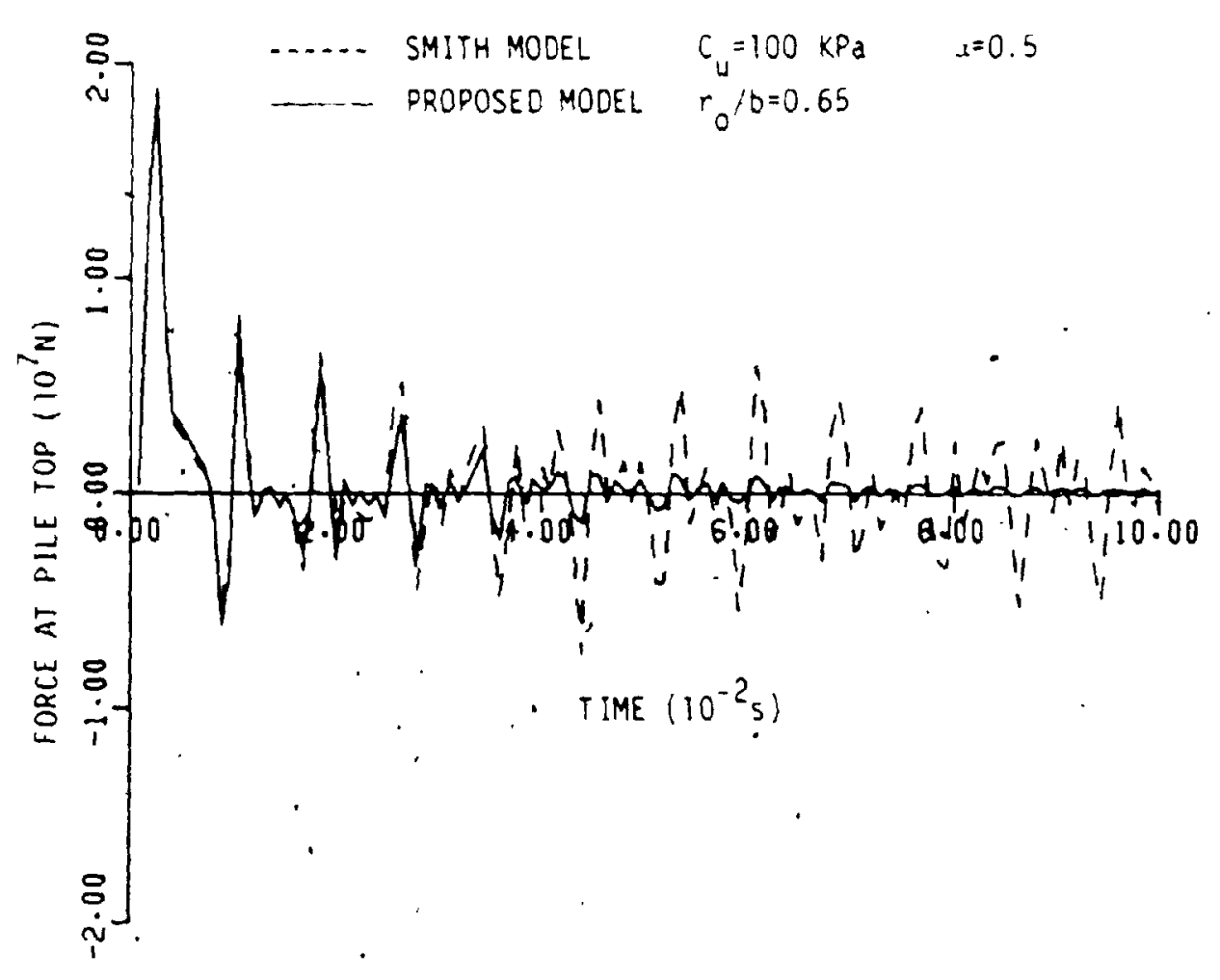

Figure 3-8: Time History of Force at Plle Top $(\alpha=0.5$ and $C_{u}=100 \mathrm{KPa}$ ) 


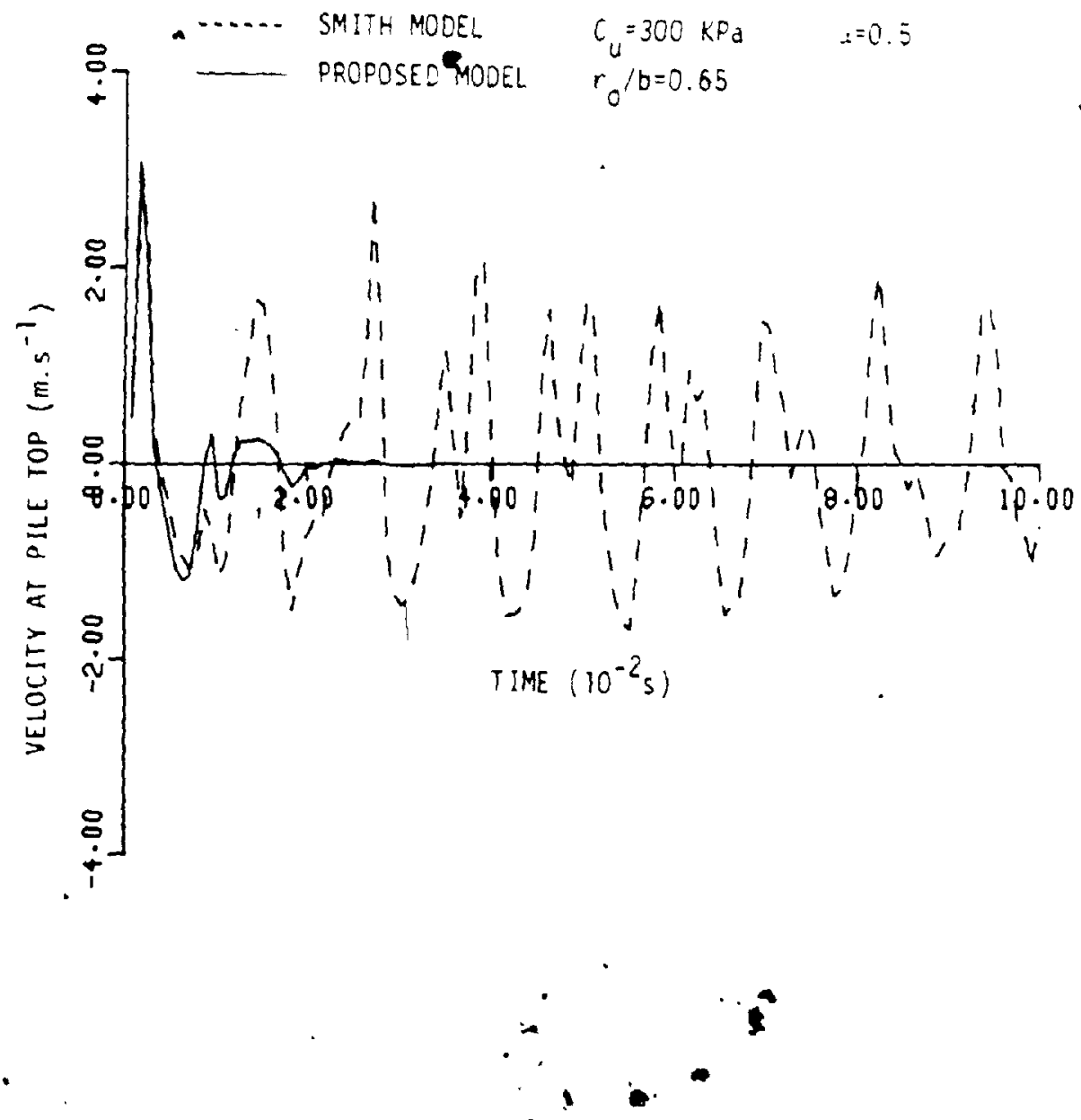

Figure 3-10: Time History of Veloclty at Plle Top $(\alpha=0.5$ and $C_{u}=300 \mathrm{KPa}$ ) 


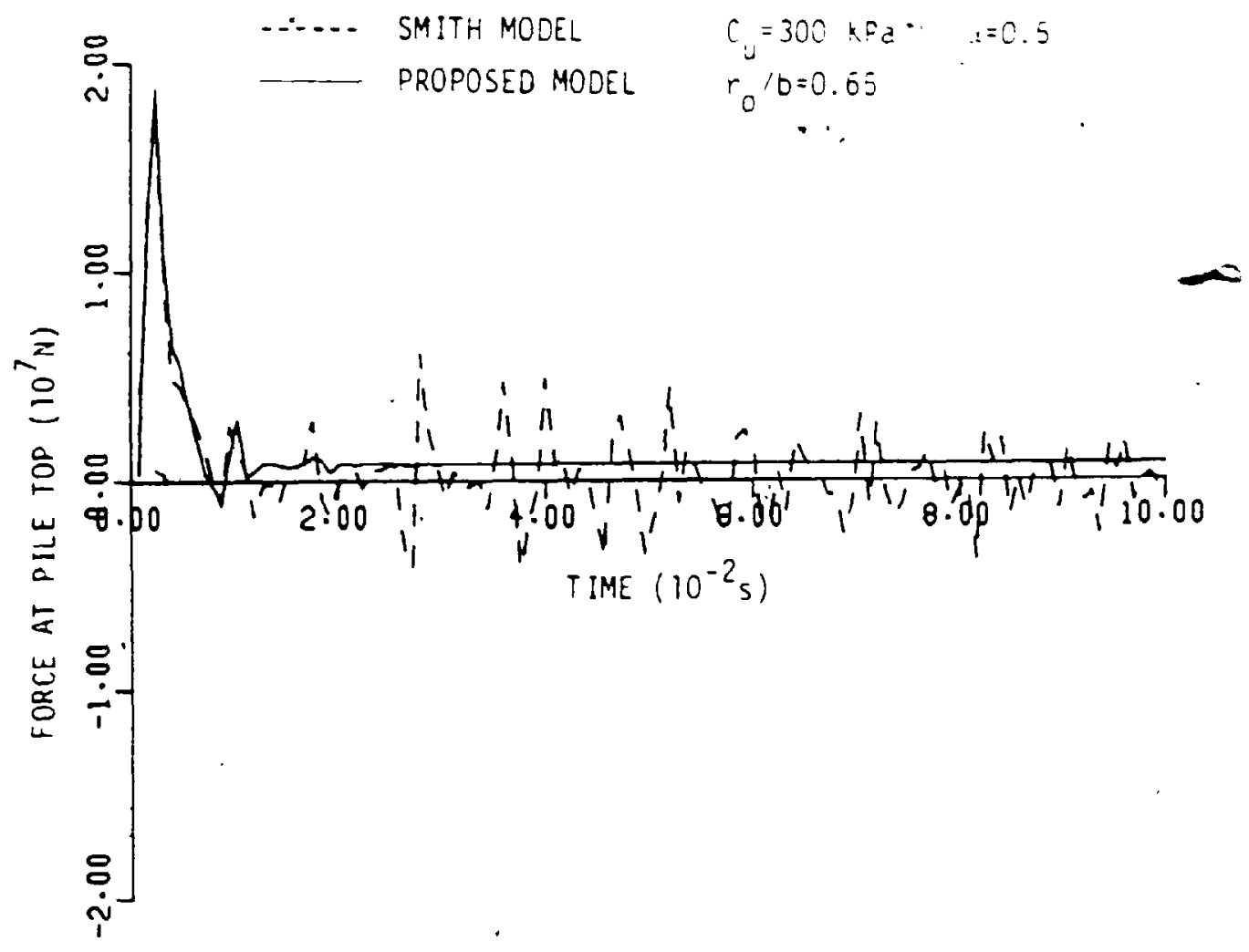

Figure 3-11: Time History of Force at Plle Top $(\alpha=0.5$ and $C_{u}=300 \mathrm{kPa}$ ) 


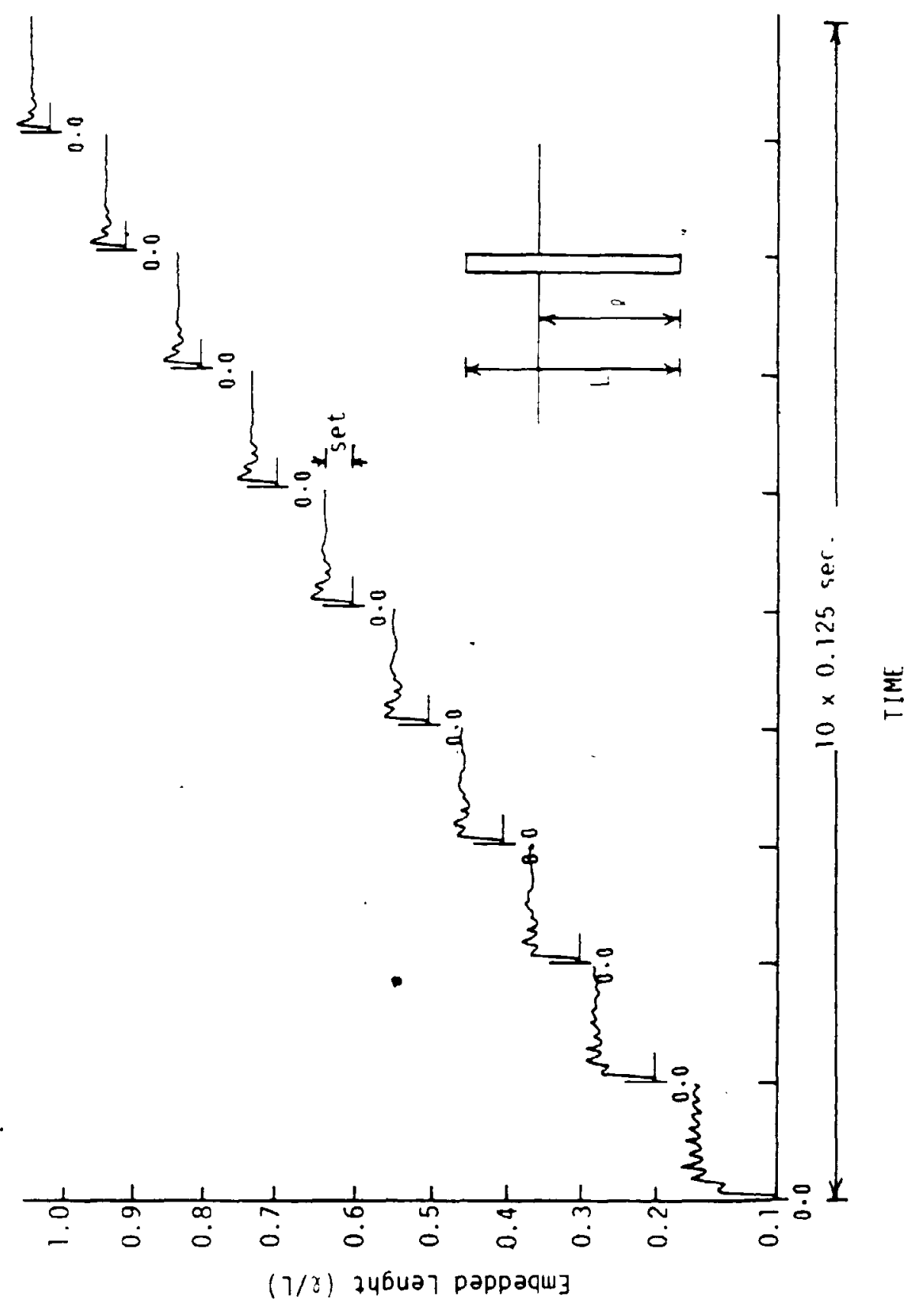

Figure 3-12: Plle Tip Displacements for Different Embedded Lengths 


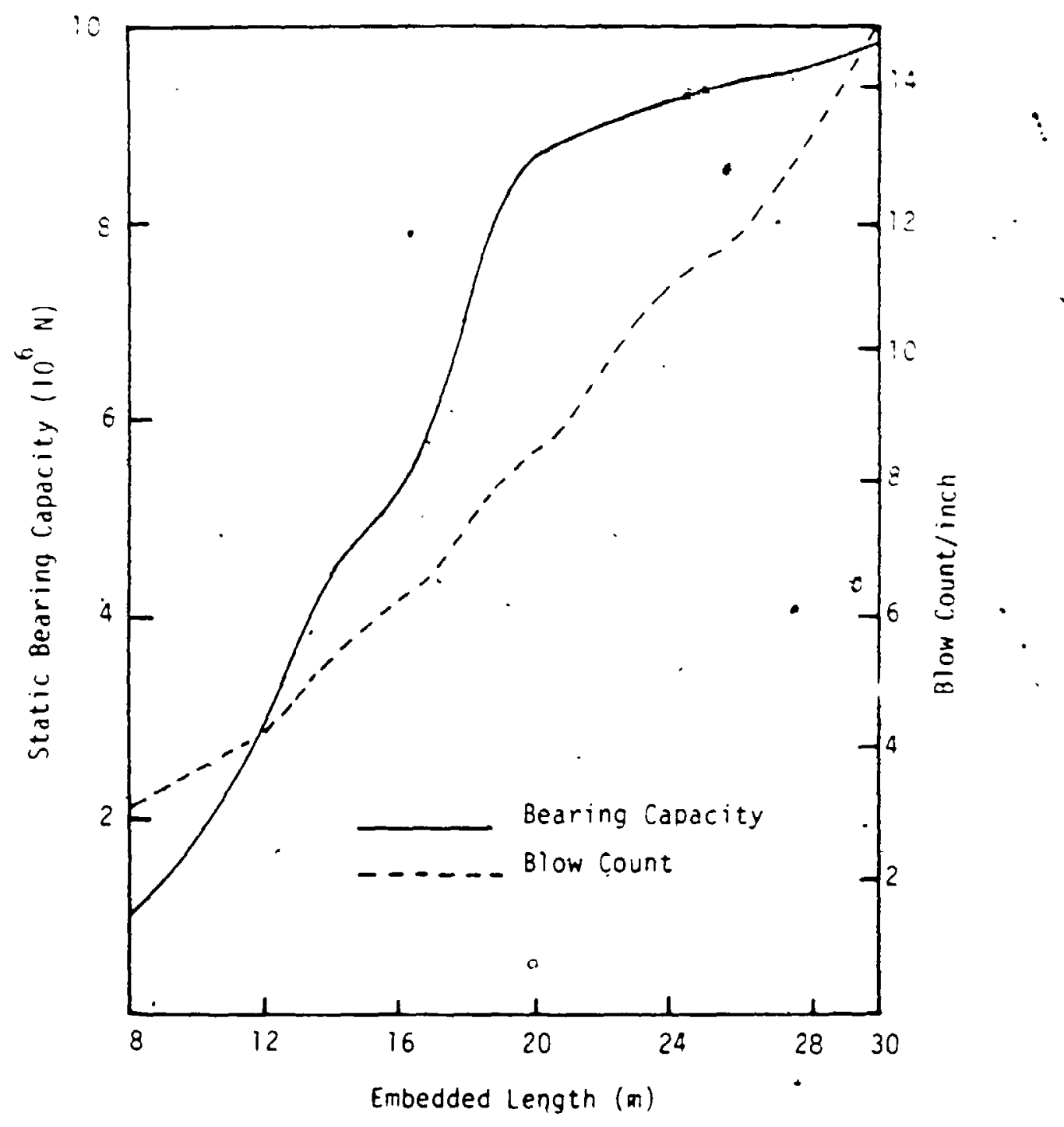

Figure 3-13: Bearing Capaclty and Blow Count for Different Embedded Lengths

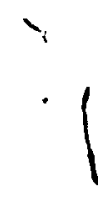




\subsection{Conclusions}

Plle driving analysls is ased to assess the drivabulty as well as predlct the plle bearlng capaclty. The conventlonal one dimenstonal Have equation analysls represents the soll reslstance using emplifical constants which might afrect its rellabllity. In thls study, soll resistance is derlved from the plane sirain soll reactlons which are based on fundamental soll propertles. Thls model takes into account the Inertial effects of the surrounding soll medium and the, noplinearlty of the soll zone adjacent to the plle in an approximate fashlon. Results obtained using thls model are compared with those of the conventlonal anglysts and the following conclusions are drawn:

1. The new soll model glves a more damped response than that obtalned from the conventlonal model, which is closer to realty and might arfect the velocity and force tlme records and consequently the evaluation of the bearing capacity.

2. The plle tlp displacement obtalned using the new soll modet is sensitive to the extent of the weakened zone around the plle which should be estimaied from comparisons with neld data.

3. The new soll moda is based on fundamental soll propertles which makes it more rellable. 


\section{Chapter Four \\ Three Dimensional Analysis of Pile Driving}

\subsection{Introduction}

The one dimensional wave equation idealization is increasingly in use for plle drlvabllity analysls. e.8. '27,28.29'. Recent advances in plle Instrumentation and measurement technlques made it possible to extend the appllcabllity of the wave equation analysls to predlct the statle plle bearing capacly 30.31.11. Due to the high costs involved with test drlving plles, especlally in the oftshore environment 21:, the need arose for a method which enables the accurate predlction of plle drlving records. Athough thls can readlly be done using the one dimensional model. the maln weakness of thls approsch is the use of non standard soll characterlstics as polnted out in Chapter 3 . Some researchers have even recommended to abandon the use of the quake value $Q$ and the damping constants $J_{s}$ and $J_{p}$ and to use a constant value for the shafe friction [32'.

Smlth et al. [17.33\} and Chow et al. [18] conducted a three dimensional nnite element analysts of the plle driving problem in an attempt to madel the soll Inertla and geometrlc damplng more realistlcally. In thelr analysls. Smith et al. used an Interface element to account for sllppage between the plle and surrounding soll and a viscous boundary to absorb elastlc waves at the boundarles of the nnlte element mesh. They concluded that whlle the one dimensional model closely dutmates the plle set. It does not accurately predict the displacement. velocity and force tlme records. More recently. Wu et al. [20] used the nnite element method to model the shan resistance durlng driving and correlate the quake and damplng constant with the soll shear modulus and yleld strain. 
In thls chapter. a nnlte element analysls of the plle-soll system is dereloped to examine the applicabllty of the nnlte element anslysls to the plle driting problem. Results of thls analysls are compared with the results of the model developed In Chapter 3 to assess the behavlour of both models A nex iransmltting boundary for vibration in the radla! direction is developed for use in the nnite element mesh.

\subsection{Transmitting Boundaries}

\subsubsection{General}

In the nnlte element method. \& nnlte region of the unbounded soll domain is represented and discretized into nnlte elements, Fig. 4.1. A vibrating body in an elastlc medlum causes the propagation of elastic waves In the continuum. These waves are reflected back inslde the mesh if elther a free or a nxed boundary is used. To allevlate thls problem, Luco and Hadjlan $\mid 34 ;$ trled to determine the amount of materlal damplng, which would account for energy radlation that otherwise takes place. In the sem! innnlte medlum and several artinclal boundarles have been proposed as a means of absorbling the radlated energy.

Lysmer et al. [35] and Kuhlemeyer [36] Introduced the viscous boundary whlch telles on the fact that the normal stress in an elastic rod is proportlonal to the partlcle veloclty at the same point taking on the character of viscous damplng. An artinclal boundary is thus formed by Imposing a viscous boundary along the mesh perlphery. When used in a contlnuum. the accuracy of the viscous boundary deterlorates with the obllqueness of the Incident waves. White et al. $[37,38$ ) attempted to Improve on the vlscous boundary and to Include soll antsotropy. They minlmized the unabsorbed energy with respect to the viscous deshpots. Lysmer and Drake [39], Introduced a conststent boundary that is especlally deslgned to absorb Raylelgh or Love waves In layered medla. Other artinclal boundarles were also suggested by different researchers, e.8. [40.41;. 


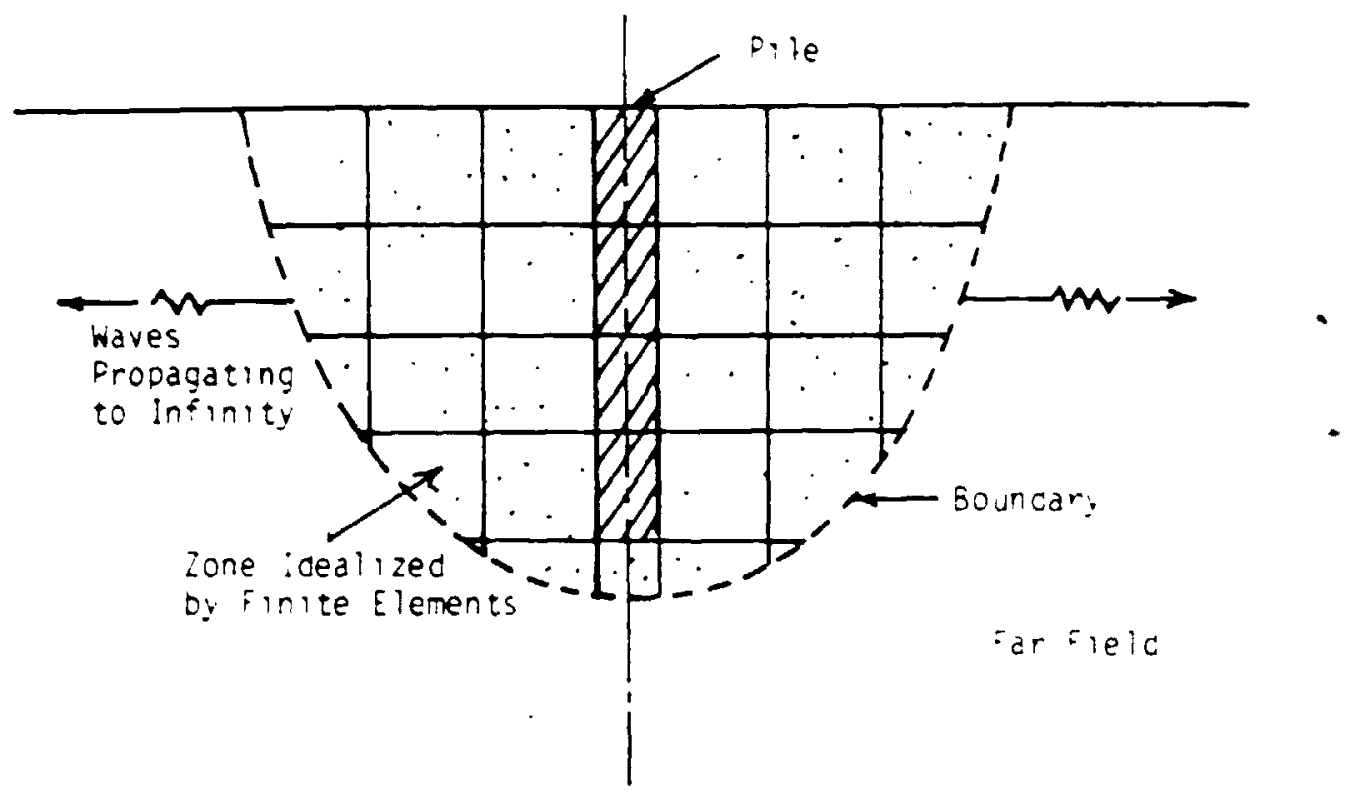

Figure 4-1: Finlte Element Modelling of a Continuum Problem

a)
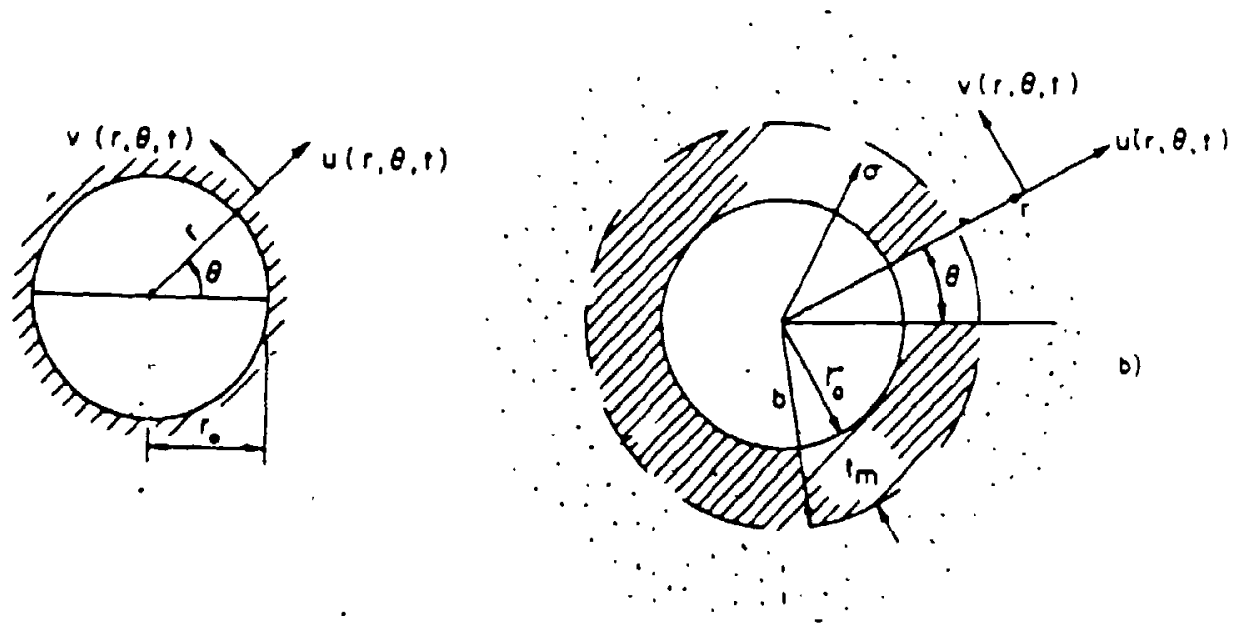

Figure 4-2: Displacemeat Components in the Cyllndrical Coordinates 
Among the several artinclal boundarles developed by varlous investigators. the standard viscous boundary is most popular due to its simpllcliy and sultabllity for Ilme domaln analysls. However, for plle driving analysls thls boundary is defficlent in that it lacks the stirfness (In phase) part which may result in further errors.

\subsubsection{Plane Strain Transmitting Boundary}

In thls study. a new transmlting boundary is formulated whtch applles to the sides of the nntue element mesh. Thls new boundary is based on the plant strain soll reactions 12 and is best sulted for frequency domain analysts. Soll reststance to harmonlc vibration of an innnltely long rigid cyllnder has investlgated by Novak et al. for all vibration modes except for the radlal axisymmetric vibration which is Investigated in this study. The following assumptlons are adopted:

1. The cyllnder is rigld, massless and innnltely long.

2. Perfect bond occurs between the cyllinder and soll medlum.

3. The soll medlum is isotropic and viscoelastlc with frequency Independent materlal damplng and is elther homogeneous as in Flg. $4.2 \mathrm{a}$ or has an inner weakened zone as in F/g. $4.2 \mathrm{~b}$.

4. The displacements are small and the vibration is harmonle.

Under these assumptlons, the equatlons of motion of a viscoelastlc continuum In the cyllndrical coordinates. Fig. 4.2, are wittien as $112 ;$

$$
\begin{gathered}
(1+123)\left\{(\lambda+2 G) \frac{\partial \Delta}{\partial r}-\frac{2 G}{r} \frac{\partial \omega_{z}}{\partial \theta}+2 G \frac{\partial \omega_{\theta}}{\partial \nu_{i}}\right\}=\rho \frac{\partial^{2} u}{\partial t^{2}} \\
(1+123)\left\{(\lambda+2 G) \frac{\partial \Delta}{r \partial \theta}-\frac{2 G}{r} \frac{\partial \omega_{r}}{\partial \theta}+2 G \frac{\partial \omega^{\prime} z}{\partial r}\right\}=\rho \frac{\partial^{2} v^{\prime}}{\partial t^{2}} \\
(1+123)\left\{\left(\lambda+2 G \frac{\partial \Delta}{\partial z}-\frac{2 G}{r} \frac{\partial\left(r_{\omega_{\theta}}\right)}{\partial r}+2 G \frac{\partial \omega_{r}^{\prime}}{r \partial \theta}\right\}=\rho \frac{\partial^{2} u}{\partial t^{2}}\right.
\end{gathered}
$$

The relatlve volume change $\Delta$ is given by 


$$
\Delta=\frac{\partial(r u)}{r \partial f}+\frac{\partial v}{r \partial \theta}-\frac{\partial u}{\partial z}
$$

and the components of the rotation vector are glven by

$$
\begin{aligned}
& \dot{\prime}_{r}=\frac{1}{2} \frac{\partial u}{r \partial \theta}-\frac{\partial u}{\partial z} \\
& -\theta=\frac{1}{i} \frac{\partial u}{\partial z}-\frac{\partial u}{\partial r} \\
& \left.\dot{L}^{\prime}:=\frac{1}{2}-\frac{\partial(r \cdot)}{r \partial r}-\frac{\partial u}{r \partial \theta}\right)
\end{aligned}
$$

In Eqs. 4.1 to 4.3. u. $u$ and $u$ are the components of displacement at a polni whose coordlnates are r, $\theta$ and $z$ at lime $t, \lambda$ and $G$ are the bulk and shegr modulll of the soll, respectlvely and 3 is the soll materlal damping ratlo..

\subsubsection{Homogeneous Medium}

Vertical Vibration: The complex soll stlffness per unlt length of the cyllnder assoclated with a unlt vertlcal displacement follows from Eq. 4.1 as

$$
\begin{aligned}
K_{v} & =2 \pi G(1+223) a_{0} \cdot \frac{K_{1}\left(a_{0}^{\prime}\right)}{K_{0}\left(a_{0}^{\prime}\right)} \\
& =G\left(S_{r 1}+2 S_{r-2}\right)
\end{aligned}
$$

where $K_{\text {, }}$ and $K_{0}$ are the modined Bessel functions of orders 1 and zero. respectively.

$$
a_{0}=a_{0} i / \sqrt{1+i 23}
$$

and

$$
a_{o}=\omega T_{o} / l^{\prime}
$$

where $l$ is the soll shear wave veloclty and $r_{o}$ Is the cyllnder radlus.

Axiaymmetric Radial Vibration: in thls case. the displacements $v$ and $u$ vanish and the equatlons of motlon of the viscoelastic continuum, Fo. 4.1. reduce 10

$$
(\lambda+2 G)(1+12.3) \frac{\partial}{\partial r}\left(\frac{\partial u}{\partial r}+\frac{u}{r}\right)=\rho \frac{\partial^{2} u}{\partial t^{2}}
$$


For the solution in the form of $u(r, t)=l(r) e^{i-t}$. Eq. $4 . ;$ becomes

$$
\frac{d^{2} l^{2}}{d q^{2}} \div \frac{d l^{2}}{q d q}-\left(1+\frac{1}{q^{2}}\right)=0
$$

where $q=s r$ and

$$
s=\frac{i}{\sqrt{v} \sqrt{1-123}} \cdot \sqrt{(1-2 \nu) / 2(1-\nu)}
$$

Eq. 4.8 is the modined Bessel Equation of the nrst order whose solution is glven by

$$
\zeta(r)=A l_{1}(s r)+B K_{1}(s r)
$$

In Eq. 4.10 $K_{1}$ and $I_{1}$ are the modined Bessel functlons of the nrst order and $A$ and $B$ are constants to be determined from the following boundary conditlons
1. $l ; \gamma_{i}=1$
se $r=$
2. $L \% \dot{r}=0$
at $r \rightarrow x$

Applying these two boundary conditions glve $A=0$ and $B=\frac{1}{\left.h_{1} \omega_{0}\right)}$. The normal stress in the radial direction is glven by

$$
\sigma_{r}=\lambda \Delta+2 G t_{r}
$$

where $c_{r}$ Is the radial strain given by

$$
\tau_{r}=\frac{\partial u}{\partial r}
$$

From Eqs. 4.10 to 4.12, the radlal normal stress is

$$
\sigma_{r}=-\frac{G}{r_{0}}\left\{2(1+i 23)\left(\frac{(1-\nu)}{(1-2 \nu)}\left(\frac{K_{o}\left(s r_{0}\right) s r_{0}}{K_{1}\left(s r_{0}\right)}\right)+1 i\right\}\right.
$$

Accordingly, the complex radial soll reaction per unlt area of contact between the cyllnder and soll medium assoclated with a unlt radlal displacement of wrltten as

$$
K_{r}=-\sigma_{r}=\frac{G}{r_{o}}\left(S_{r 1}+i S_{r 2}\right)
$$




\subsubsection{Nonhomogeneous Medium}

When the cyllnder experlences large displacement amplltudes. sllp might occur between the cyllnder and the soll. Near the cyllnder, the soll behaves nonllnearly. As the straln increases, the shear modulus decreases, materla! damping Increases and the affected zone around the plle can be regarded as a Heakened zone. An approxlmate approach was formulated whtch considers the soll zone with large deformations around the plle, Fig. 4.2b, as a zone with reduced shear modulus [25]. Soll reslstance is then calculated approxlmately assuming that the plle is surrounded by a medlum consisting of an' Inner soft layer and an outer harder one.

Vertical Vibration: Novak and Shets [25] consldered the Inner lay'er to be massless and the complex stiffness of the composite medlum follows as:

$$
\begin{aligned}
K_{r}= & \frac{2 \pi\left(G_{m} / G\right)}{-\ln \left(r_{0} / b\right)+\left(G_{m} / G\right) K_{0}(3 b) / 3 b K_{1}(3 b)} \\
& =G\left(S_{i 1}+2 S_{12}\right)
\end{aligned}
$$

where $s$ is glven by

$$
s=\frac{i \omega}{v \sqrt{1+i 2 \beta}}
$$

Thls solution was used In Eq. 3.19 for the one dimenslonal model.

Veletsos and Dotson [42] formulated the solution for the vertical direction consldering the mass of the Inner zone and concluded that the differences Introduced due to neglecting it may be substantlal at high dimenslonless $-$ frequencles. Lakshmanan and Minal [43] considered the shear modulus to vary llnearly with dlstance in the weakened zone and accounted for the mass of the Inner zone.

Radial Axiaymmetric Vibration: In thls chapter, the complex stiffness of 
the composite medlum for the case of radial axisymmetric vibration ts formulated consldering the mass of the inner zone. As In the case of the homogenecus: medlum. the displacements are expressed in terms of the modined Besse! functions, l.e.

$$
\begin{array}{ll}
u(r)=U_{1}\left(s_{1} r\right)+B K_{1}\left(s_{1} r\right) & r_{0} \leq r<b \\
u(r)=C I_{1}\left(s_{0} r\right)+D K_{0}\left(s_{0} r\right) & r \geq b
\end{array}
$$

where $s_{1}$ and $s_{0}$ are the parameters $s$, denned by $E_{q} .4 .9$ of the Inner and outer zones, respectively. The constants $A, B, C$ and $D$ are determined from the following boundary condltlons
1. $l(r)=0$
st $r \rightarrow x$.
2. $l(r)=1$
at $r=$.

3. The displacements of both medla are equal at $r=b$.

4. The normal stresses of both medla an fequal at $r=b$.

Application of these boundary condltions ylelds $C=0$ and, after rather lengthy mantpulations, the following values for $A, B$ and $D$ :

$$
\begin{aligned}
& A=\left\{\alpha \gamma \mid s_{1} r_{o} \frac{K_{0}\left(s_{i} b\right)}{K_{1}\left(s_{1} r_{0}\right)}+\frac{K_{1}\left(s_{i} b\right)}{b / r_{0} K_{1}\left(s_{i} r_{0}\right)}\right\}+\frac{1}{b / r_{0}}(1-\alpha) \frac{K_{1}\left(s_{i} b\right)}{K_{1}\left(s_{i} r_{0}\right)} \\
& \left.-\gamma\left|s_{0} r_{0} \frac{K_{0}\left(s_{0} b\right) K_{1}\left(s_{i} b\right)}{K_{1} s_{1} r_{0} K_{1}\left(s_{0}^{b} b\right)}+\frac{K_{1}\left(s_{0} b\right)}{b / r_{0} K_{1}\left(s_{1} r_{0}\right)} \cdot \frac{K_{1}\left(s_{1} b\right)}{K_{1}\left(s_{0}^{b} b\right.}\right|\right\} / \\
& \left\{\alpha \gamma\left[s_{i} r_{0} I_{0}\left(s_{i} b\right)+\frac{I_{1}\left(s_{i} r_{0}\right)}{K_{1}\left(s_{i} r_{0}\right)} s_{1} r_{0} K_{0}\left(s_{1} b\right)\right]\right. \text {. } \\
& +\gamma \mid\left(\frac{H_{1}\left(s_{i} r_{0}\right) K_{1}\left(s_{i} b\right)}{K_{1}\left(s_{i} r_{0}\right) b / r_{0}}-\frac{I_{1}\left(s_{i} b\right)}{b / r_{0}}\right)(\alpha-1)+\frac{I_{1}\left(s_{i} b\right)}{K_{1}\left(s_{0} b\right)} s_{0} r_{0} K_{0}\left(s_{0}^{b} b\right) \\
& \left.-\frac{I_{1}\left(s_{1} r_{0}\right) K_{1}\left(s_{1} b\right)}{K_{1}\left(s_{1} r_{0}\right) K_{1}\left(s_{0} b\right)} s_{0} r_{0} K_{0}\left(s_{0} b\right)\right] \\
& -\frac{\delta}{b / r_{0}}(1-\alpha)\left\{I_{1}(s, b)-\frac{I_{1}\left(s_{3} r_{0}\right)}{K_{1}\left(s_{1} r_{0}\right)} K_{1}(s, b) i\right\}
\end{aligned}
$$

and 


$$
\begin{aligned}
B= & \frac{1}{K_{1}\left(s_{1} r_{0}\right.}-A \frac{I_{1}\left(s_{i} r_{0}\right)}{K_{1}\left(s_{1} r_{0}\right)} \\
D= & A \frac{I_{1}\left(s_{1} b\right)}{K_{1}\left(s_{0} b\right)}-\frac{I_{1}\left(s_{i} r_{0}\right)}{K_{1}\left(s_{1} r_{0}\right)} \frac{K_{1}\left(s_{i} b\right)}{K_{1}\left(s_{0} b\right)} \\
& -\frac{K_{1}\left(s_{1} b\right)}{K_{1}\left(s_{0} b\right) K_{1}\left(s_{1} r_{0}\right)}
\end{aligned}
$$

The normal stress in the radial direction is glven by Eq. 4.11 and at $r=r_{0}$ is glven by:

$$
\begin{aligned}
& \sigma_{r}=-2 \frac{G_{m}}{r_{o}}\left(1+i 23_{m}\right)\left(\gamma\left\{A \mid s_{1} r_{o} I_{0}\left(s_{1} r_{o}\right)-I_{1}\left(s_{1} r_{o}\right)\right\}\right. \\
& \left.-B\left[s_{2} r_{0} K_{0}\left(s_{1} r_{0}\right)+K_{1}\left(s_{1} r_{0}\right)\right]\right\}+\delta\left[A J_{1}\left(s_{1} r_{0}+B K_{1}\left(s_{1} r_{0}\right)\right]\right)
\end{aligned}
$$

Hence, the complex soll reaction of the composite medlum per unlt area of contact between the cyllnder and the soll assoclated with a unlt displacement in the radial direction is given by

$$
K_{r}=-\sigma_{r}=\frac{G_{m}}{r_{o}}\left(S_{r 1}+i S_{r 2}\right)
$$

In Eqs. 4.18 and 4.21

$$
\begin{aligned}
& \alpha=\frac{G_{m}}{G} \frac{\left(1+i 2 \beta_{m}\right)}{(1+i 2 \beta)} \\
& \gamma=\frac{(1-\nu)}{(1-2 \nu)}
\end{aligned}
$$

and

$$
\delta=\frac{\nu}{(1-2 \nu)}
$$

Flg. 4.3 shows the vartation in $S_{r 1}$ and $S_{r 2}$ with $a_{o}$ for the homogeneous medlum. Statlc stirrness is obtalned at $a_{0}=0$, then the stlriness parameter $S_{r 1}$ decreases with the Increase In $a_{o}$, at a higher rate with higher Polsson's ratios. Damplng is derlved solely from materlal damplng at $a_{0}=0$, then $S_{r 2}$ increascs 


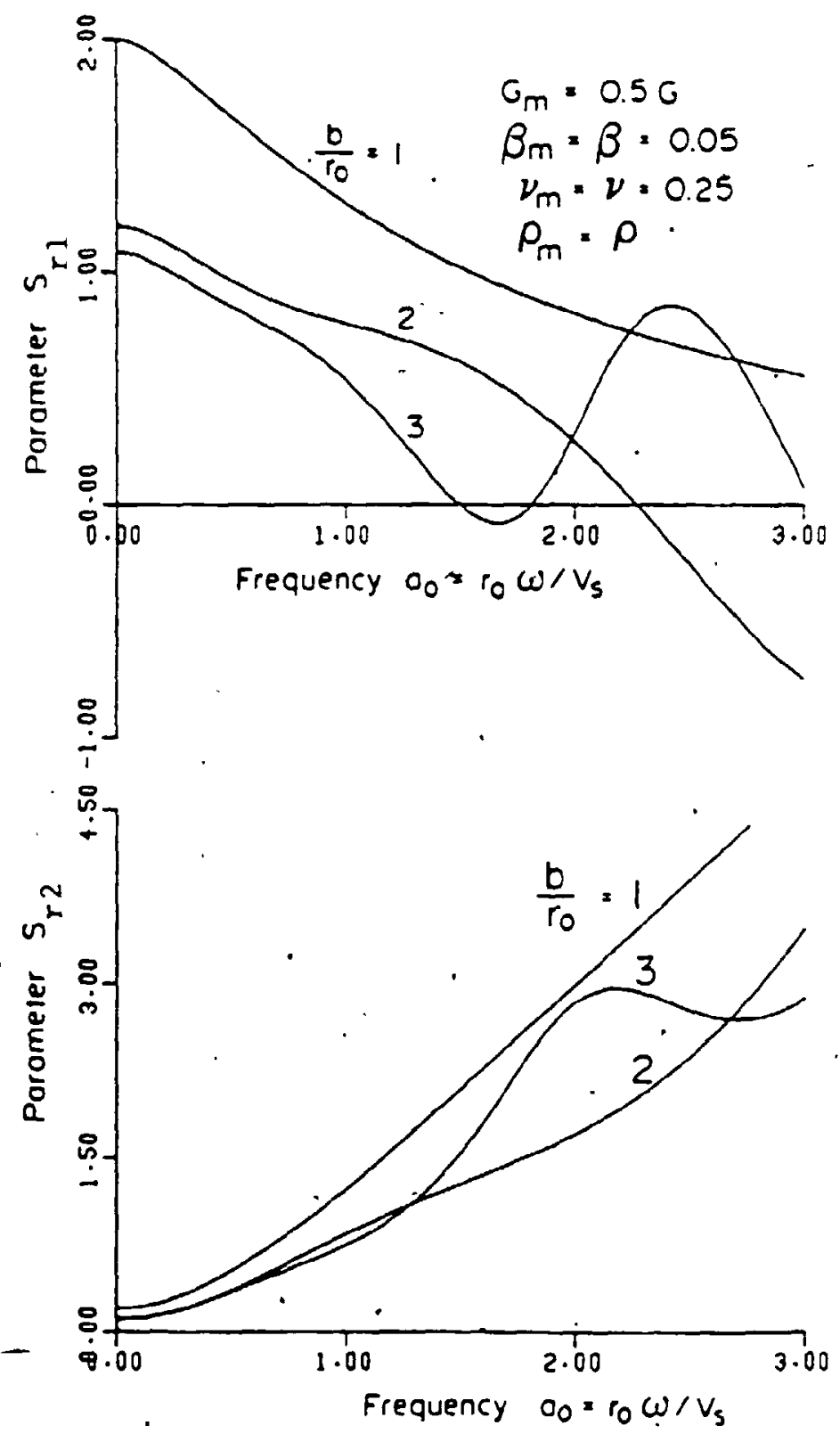

Figure 4-3: Plane Straln Axlsymmetrlc Radial Stuffness and Damplng for a Homogeneous Medlum 
dumost linearly wh frequency. Shown in Fig. 4.4 is the varlation $\ln . S_{-1}$ and $S_{\text {r: }}$ with $a_{0}$ for the composlte medlum for different $b$ ' $r$ patlos. The stlffness and damping are mostly reduced for all frequencles due to the presence of the weakened zone. Both the real and Imaginary parts osclllate at higher bir "ratiss. This boundary with weakened zone can be partlcularly useful in problem: Involving cavity expansions, l.e. soll deformaton at plle tlp. explostons, etc.

\subsection{Implementation of the Plane Strain Transmitting}

\section{Boundary}

\subsubsection{Finite Ėlement Formulation}

The cyllndrical axisymmetrlc element used by kuhlemeyer :38. Is used in ints study to model the plle and the soll (Flg. 4.5). However. the stlffness matrix glven in [36 has a few errors, and the correct expresslons could not be found in the literature. Thus the stiffness matrix was derlved from first princlples in thls study. The displacement neld $\{\delta\}$ is expressed as

$$
\{\delta\}=\{x:\{u\} \text {. }
$$

where $\{v\}$, Is the shape runctions matrlx and $\{u\}$, is the element nodal displacements. The element strain vector $\{\epsilon\}_{f}$ is related to the element nodal displacements by

$$
\{c\}_{e}=|B|\{. u\}_{e}
$$

and the stress straln relatlonshlp follows from

$$
\{\sigma\}_{e}=\{D:\{\epsilon\} \text {. }
$$

where $\{\sigma\}$, is the element stress vector and $\{D \mid$ is the elastlclty matrix. Applying the theory of virtual work ylelds the following expresston for the stirnness matrlx

$$
[K]=\int \cdot \iint_{v}(B\}^{T}(D)|B| d V
$$

The matrix of shape functlons used in Eqs. 4.26 to 4.29 Is the same one given in [36]. The stlffness matrix derlved. using thls procedure is glven in Appendix A. 

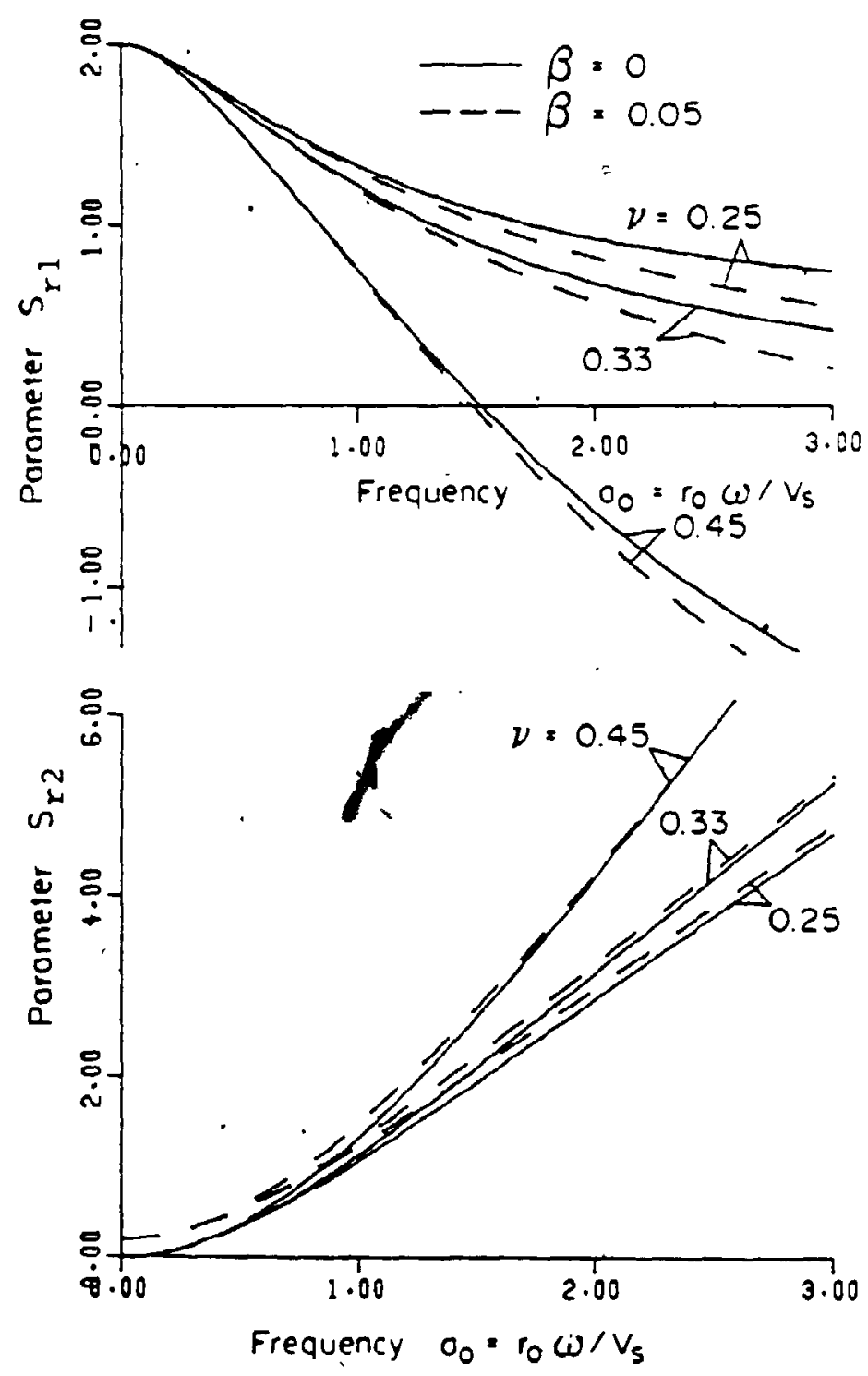

Figure 4-4: Plane Straln Axlsymmetrlc Radial Suffness and Damplng ror a Composile Soll Medlum 

Equations of motlon of the system are wittien in matrlx form as

$$
\text { i.K. }\{u\}-: C:\{u\}+: K:\{u\}=\{P\}
$$

where $, M, ; C ;$ and $; K$; are the global mass, damping and surfress matflces. respectively, $\{u\} .\{u\}$ and $\{u\}$ are the vectors of acceteratlons, velocliles and displacements, respectlvely, and $\{P\}$ is the vector of external loads.

Eq. 4.30 can be solved by three dirferent methods depending on thr nature of the problem

1. Time domain analysis (step by step numerlcal Integration' is sultable for translent and nonllnear problems and systems with frequency independent parameters.

2. Complex frequency response is sultable for elther translent or steady: state response as bong as the. system parameters are rrequency dependent and the system is llnear.

3. Modal superposition is sultable for systems that decouple easlly and $\therefore$. When the nrst rew modes are surncleat to express the response.

\subsubsection{Boundary Stiffness and Damping Matrices}

When surface tractlons are applled to one of the elements, the resulting vector of element nodal loads $\{P\}$, is glven by

$$
\left.\left\{P_{c}\right\}=\iiint_{S} \mid N^{T}\right\}^{T}\{q\} d S
$$

where $\{q\}$ Is the vector of surface tractlons and $S$ denotes a surface Integral. Imposition of the proper boundary condlitions at the mesh boundarles corresponds to applying the proper soll reactlons in the form of surface tractlons to the elements falling on the boundarles.

Let $\{q\}_{b}$ be the vector of soll reactions applled to the boundary elements which can be wirltien as

$$
\{q\}_{b}=\{-\tau-\sigma\}^{T}=-\{B D\}\{u\},-\{B S\}\{u\},
$$

In Eq. 4.32. $|B D|$ and $|B S|$ are the damplng and stiffness matrlces corresponding 
to the soll reactions to be applled at the mesh boundarles and the subsctpts Indlcates that the veloctiles and displacements ape at the element surface the vectors $\{u\}$, and $\{u\}$, are slien by

$$
\{u\}_{0}=. \therefore\{u\} \text {. }
$$

and

$$
\{u\}=P\{u\},
$$

where $\{4\}$, is the vector of eidment veloclites. From Eqs $431: 04.34$

$$
\begin{aligned}
& \{P\}=\left\{\iint_{\Omega} \cdot V^{\top} B D . . \mathrm{V} d S\right\}\{u . \\
& -\left\{\iint N^{\top} B S \ldots \times d S\right\}\{u\} . \\
& =-C B_{,}\{u\},-K B_{, \rho}\{u\},
\end{aligned}
$$

where $C B_{\text {,e }}$ and $K B^{\prime}$, are the element boundary damplng and sturfness matrices, respectliely. which can be Included Into the global boundary damplng and'stirness matrices $C B$ and $K B$. respectlvely. Hence. $E_{q} 4.30$ is rewrllten 25

$$
\{M:\{u\}+C \cdot C B:\{u\}+K+K B,\{u\}=\{P\}
$$

The viecous boundary does not have a real part of stlffnes. Ie $B S_{:}=0^{\circ}$. For a horlzontal boundary with radial and vertleal disflacements ir $v^{T}$. the element boundary damplng matrlx is defined as

$$
i_{H}=\left(\begin{array}{cc}
\rho l & 0 \\
0 & \rho V_{p}
\end{array}\right)
$$

where $l_{p}$ is the primary wave veloctly $\left(l_{p}=\sqrt{(2 G+\lambda), p}\right.$, The elemen: boundary damping matrix for a vertlcal boundary is glven by

$$
|B D|_{l}=\left[\begin{array}{ll}
0 & \rho l \\
\rho l_{p} & 0
\end{array}\right]
$$

Proposed Boundary: It is assumed that the stresses at a polnt on a vertical boundary (stdes of the mesh) are equal to the plane straln soll reactlons for the radial and vertical vibratlons described earller. Accordingly, for the vertlcal . boundary, the element boundary stirfness matrix is denned by 

horlzontal soll reactlons at the mesh base because the horlzontai displacement at the bace are very small and could even be neglected.

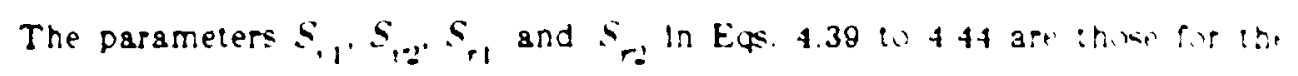
homogeneous medlum as 4 is assumed that the soll outidt the natie element: mesh remalns elastlc. It can be seen from $\mathrm{F} / \mathrm{g}$ to that the pararian.

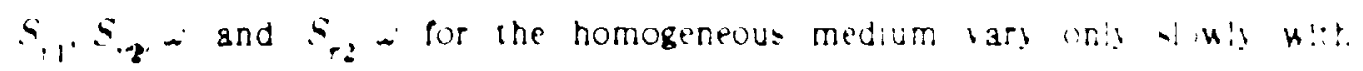
frequency and so does the parsmeter $C_{,-2}$. The sturness parameters $r_{-1}$ an: $c_{,}$

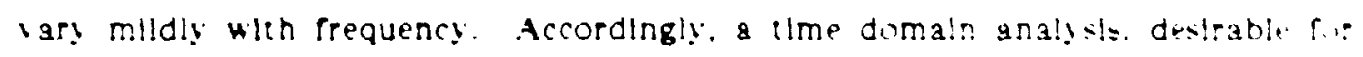
the nonllnear problem of plle driblng. can be performed using the pronosed boundary If the soll reactions are evaluated at a frequency cluse to the dominant excltation frequency.

\subsection{Verification of the Plane Strain Transmitting Boundary}

A nnlte element computer program is developed in this siudy to analyse the plle dribing problem. A fen examples are analysed to examine the performance of both the viscous and plane straln boundarles in both the frequency and ilme domalns. To evaluate the response in the tlme domaln. the Nen mark-3 method Is used for numerlal Interration of the equations of motion. In the frequency domaln. the complex frequency response method is used. in the latter approach. both the exclung force and response are harmonlc and are urltten as

$$
\{P(t)\}=\left\{P_{o}\right\} e^{i-t}
$$

and

$$
\{u(t)\}=\left\{u_{i}\right\} e^{i n t}
$$

where $\left\{u_{e}\right\}$ is a vector of complex response amplltudes. By substltuting Eqs. 4.45 and 4.46 Into Eq. 4.30 , one zets

Hhich can also bofritten as

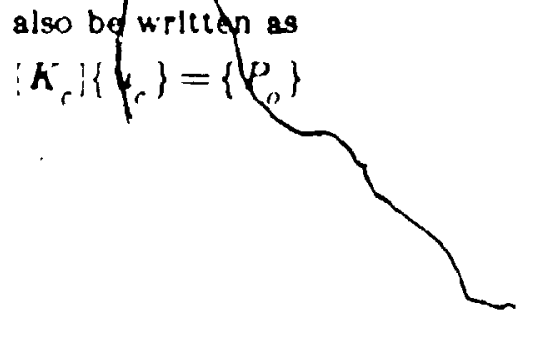



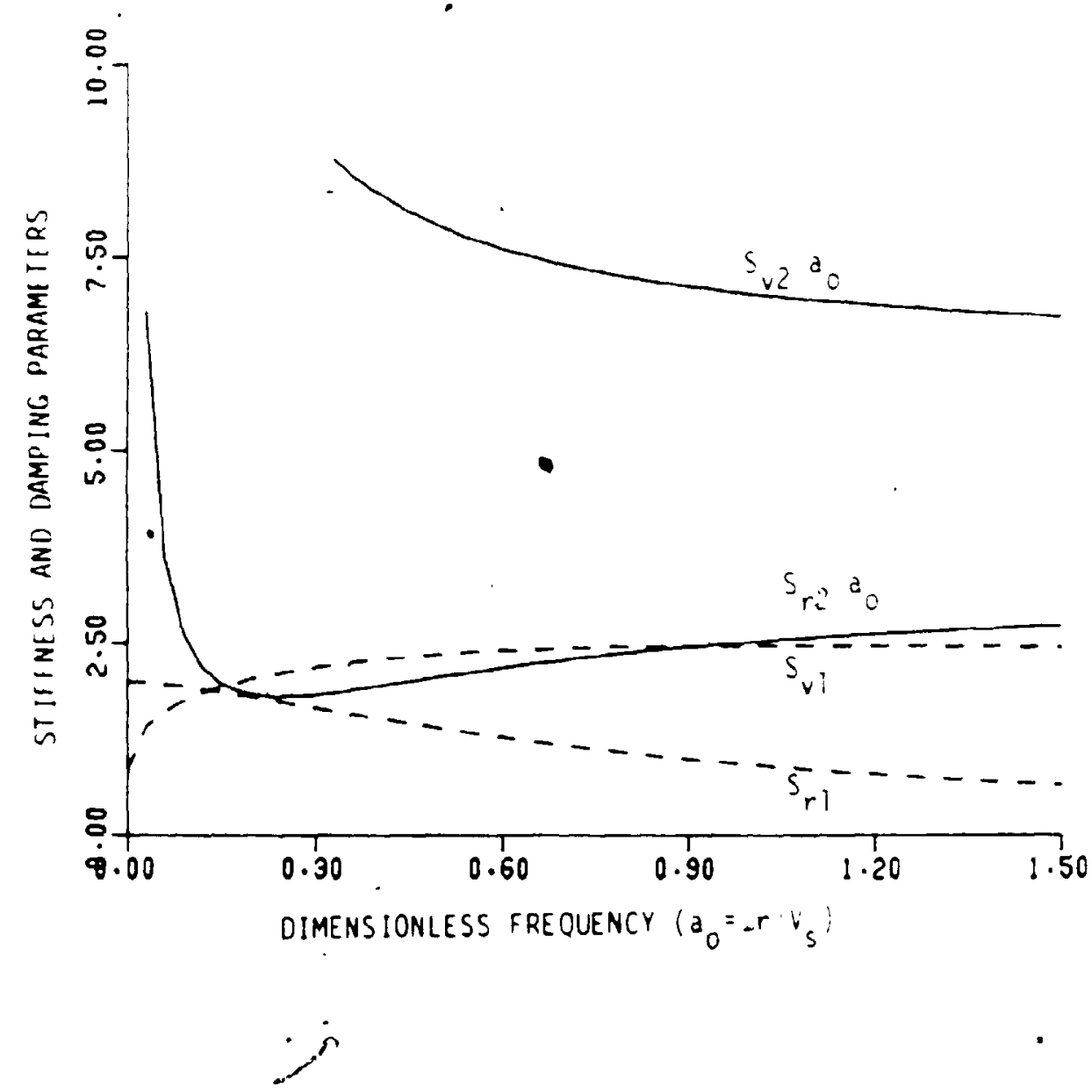

$\bullet$

Figure 46: Varlation in the Transmltting Boundary Parameters,

$$
S_{i 1}, S_{i 2} / a_{0} \text { and } S_{r 2} / a_{0} \text {. wilh Frequency }
$$


where $K_{r}$; is a complex. Prequency dependent stimness matrix. Material damping Is considered to be of the hysteretic rrequency Independent ty pe and is Included in the analysls by expressing it in terms of the equlvalent vlscous damping if

$$
\because C_{.9}^{\prime}=\frac{23}{i} h
$$

where 3 is the materlal damplng ratlo, In thls case. the comfle stirfresw math Is glven by

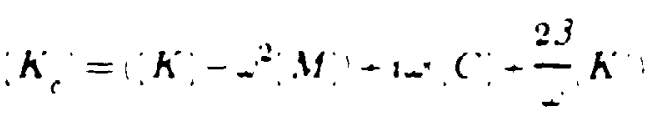

The examples considered for the verlncation are the werl-a: libratt in of an elastle bar. an embedded plle and a surface foundation.

\section{Vertical Vibration of an Elastic Bar}

The simple case of a seml innnlte elastle bar is chosen in lllustrate the effects of

- the viscous boundary. The bat is assumed to be purely elastic and materia! damplng is neglected. Only a nnlte length of the bar can be modeled by nnlte elements. The load is applled at one end of the bar and at the other end. elther a nxed or a viscous boundary is specined. The bar axlal stiffness Is $E$. $l$ where $E$ . A and $L$ are the Young's modulus, cross section area and length of the har. respectively.

The response of the bar (axlal displacement of the polnt of load application 10 a suddenly applled constant force $P(t)=P_{o}$ is evaluated for both type of boundarles and the results are shown to Flg. 4.7. The exact displacement at the bas top is also shown in Fig. 4.7 and is given by

$$
u_{1}=\frac{P_{o} V_{p}^{\prime}}{E A}
$$

where $V_{p}$ is the one dimenstonal prlmary wave veloclty defined In Ea 3 I Arbltrary values are assigned to $P_{o}, E, A$ and $V_{p}$ such that $P_{o} V_{p} / E . A=1 \mathrm{~m}$, s, hence, $u(t)=t$. It can be seen that the application of the nxed boundary leads to 
4

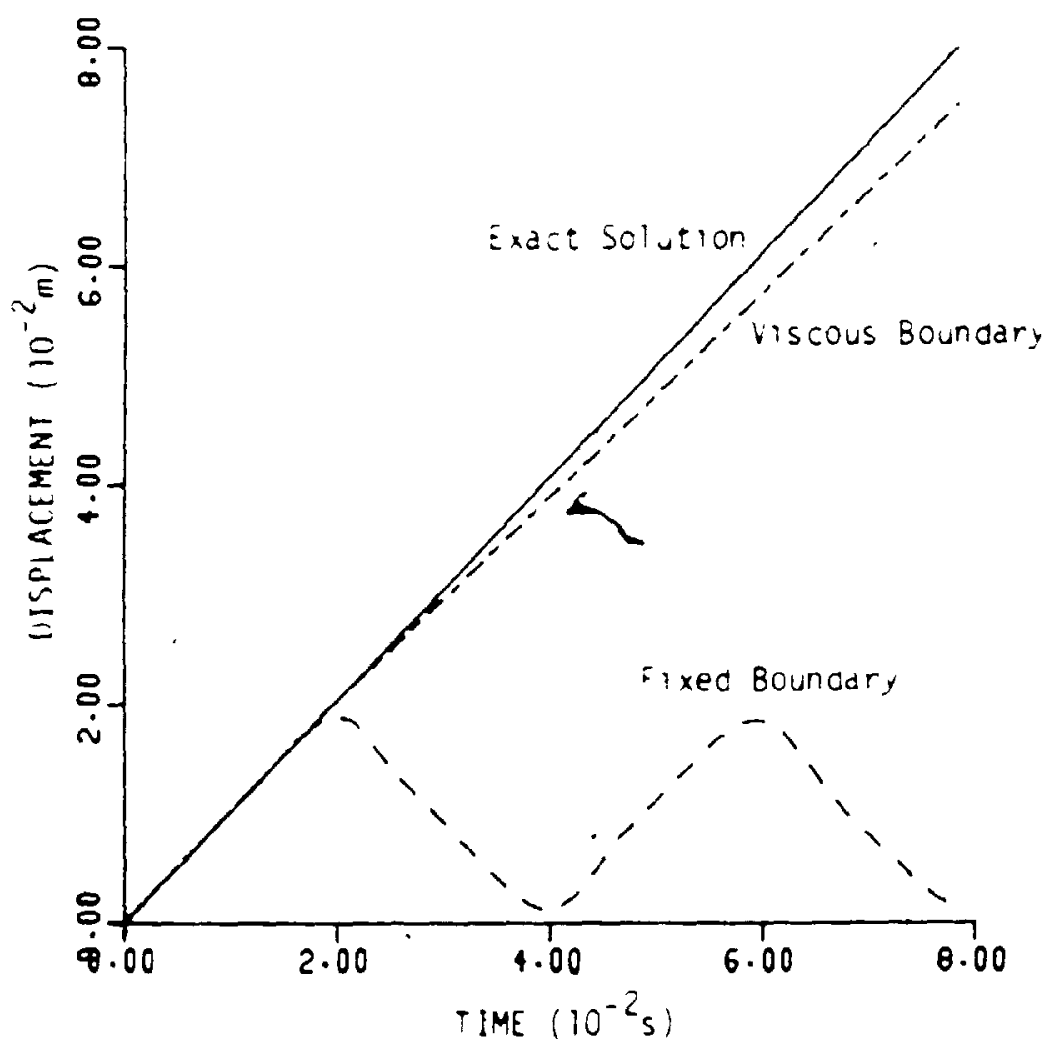

Figure 47: Displacement of a Seml Innnite Elastic Hat Subjected io a Constant Load $\left(P_{o} l_{p}, E A=1 \mathrm{~m} / \mathrm{s}\right)$ 
an osclllatory response wheress the appllcation of the viscous boundary glves a Ilnear displacement that increases with tlme and Is very close to the exact solution. Fig. 4.8 show's the axlal stresses Inslde the bar calculated at lime $t=3 L_{/ 2} l_{p}^{\circ}$ for both boundarles as well as the exact solution $\sigma=P_{o^{\prime}} \cdot A$. The values chosen for $P_{0}$ and $A$ are such that the resulting stress is unlty. At lime $t=3 L / 2 l_{p}^{\circ}$. the stress wave will have enough time to cover a distance of $3 L / 2$. Whlle the viscous boundary absorbs the outgoing stress wave leading to the correct results, the nxed boundary reflects the stress kave back Inside the modeled zone yielding distorted results. Flg. 4.8 show's the response of the bar to a harmonic excliatlon glven by $P(t)=P_{0} \cos$ i't. fo: both boundarles. For thls case. $P_{\sigma} / E .4$ is chosen to be equal to 0.002 and the perlod $T$ of the harmonlc load is $0.1 \mathrm{~s}$. The response evaluated using the vlscous boundary is osclllatory around a non zero constant value whlch is attributed to the absence of a real part or stifness in the viscous boundary. Uising a nxed boundary, however. ylelds a symmetrlc harmonlc osclllation.

\section{Vertical Vibration of an Embedded Pile}

The vertlcal vibration of a single plle is analysed in the frequency domain as well as the tlme domaln. Both, the statc and dynamlc stifrnesses in the vertlcal direction are evaluated and compared to other nnlte element and analytical solutions.

In the frequency domaln. the complex springs representing the boundarles. shown in Flg. 4.10, are evaluated at the excltation frequency and the resulting damping and stifrness boundary matrices are assembled in the global complex stiffness matrix $\left|K_{c}\right|$. Eq. 4.48 is used to evaluate the complex stiffness of a single plle by specifylng a unit vertlcal displacement at the plle top. The vertical complex stiffness of a single plle is wricten as 



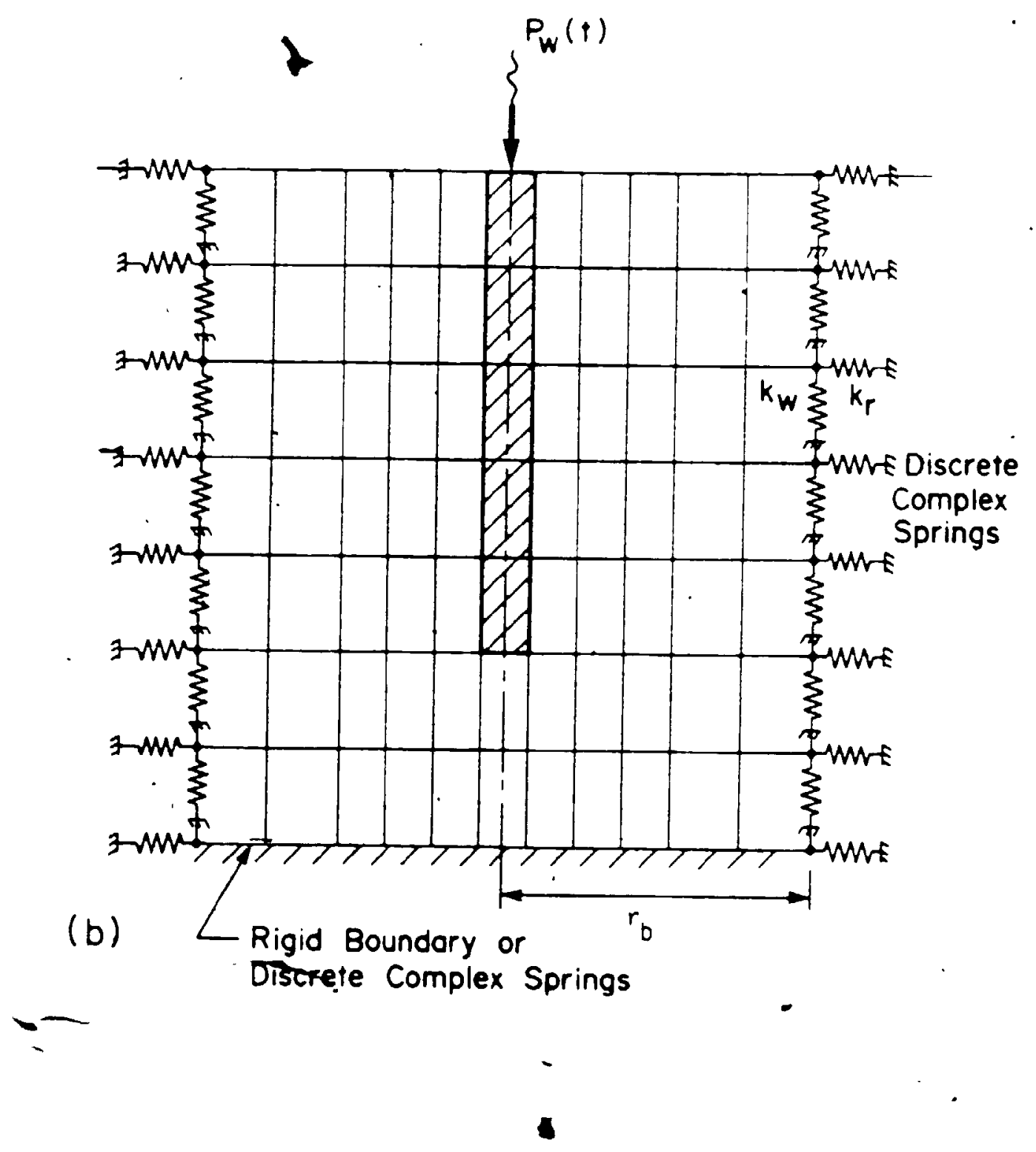

Figure 4-10: Finlte Element Mesh with Transmlting Boundary . 


$$
K=K_{1}+K_{2}
$$

The dimenslonless parameters $f_{11}$ and $f_{12}$ which represent the verital stiffness and damplng. respectlvely, of a single plle are eraluated in orter th compare the results with Novak's solution '48'. These parameters are denned as

and

$$
f_{, 1}=\frac{K_{1} r_{0}}{E_{p} A_{p}}
$$

$$
f_{\because}=\frac{h_{2} \tau_{0}}{a_{o} E_{p} A_{p}}
$$

where $E_{p}, A_{p}$ and $r_{0}$ are the plle Young's modulus, cross secilon area and rathus respectively.

First, the statlc stirrness is evaluated using the proposed boundary and the results are compared wilth Poulos solution i47: In Flg. 4.11 for 3 different stiffness ratlos $\left(E_{p} / E_{q}\right.$, where $E_{a}$ is the soll Young's modulus). Both solutions agree qulte well especlally at blether $E_{p} / E_{p}$ ratlos. The dimenslonless parameters $f_{1}$ and $f_{12}$ are evaluated for a vertlcal noating plle using the proposed boundary and are shown In Fle. 4.12. Also shown In Fig. 4.12 are $f_{11}$ and $f_{t: 2}$ evaluated using the viscous boundary as well as those obtalned by rovak. It can be seen that the results obtalned using the proposed boundary are closer to Xovak's solution than those obtalned using the viscous boundary. Flg. 4.13 shows the vertlcat stifrness and damplng of a hoating plle calculated using the proposed boundary compared to those obtalned by Ostadan $\mid 48$ i using a nnite element analysls. A good agreement between the two solutions.ls' observed except at lower dimenslonless

Vrequencles where the damplng calculated using the proposed boundary exceeds that obtained by Ostadan.

To check the proposed boundary in the time domaln, a vertical noating plle 


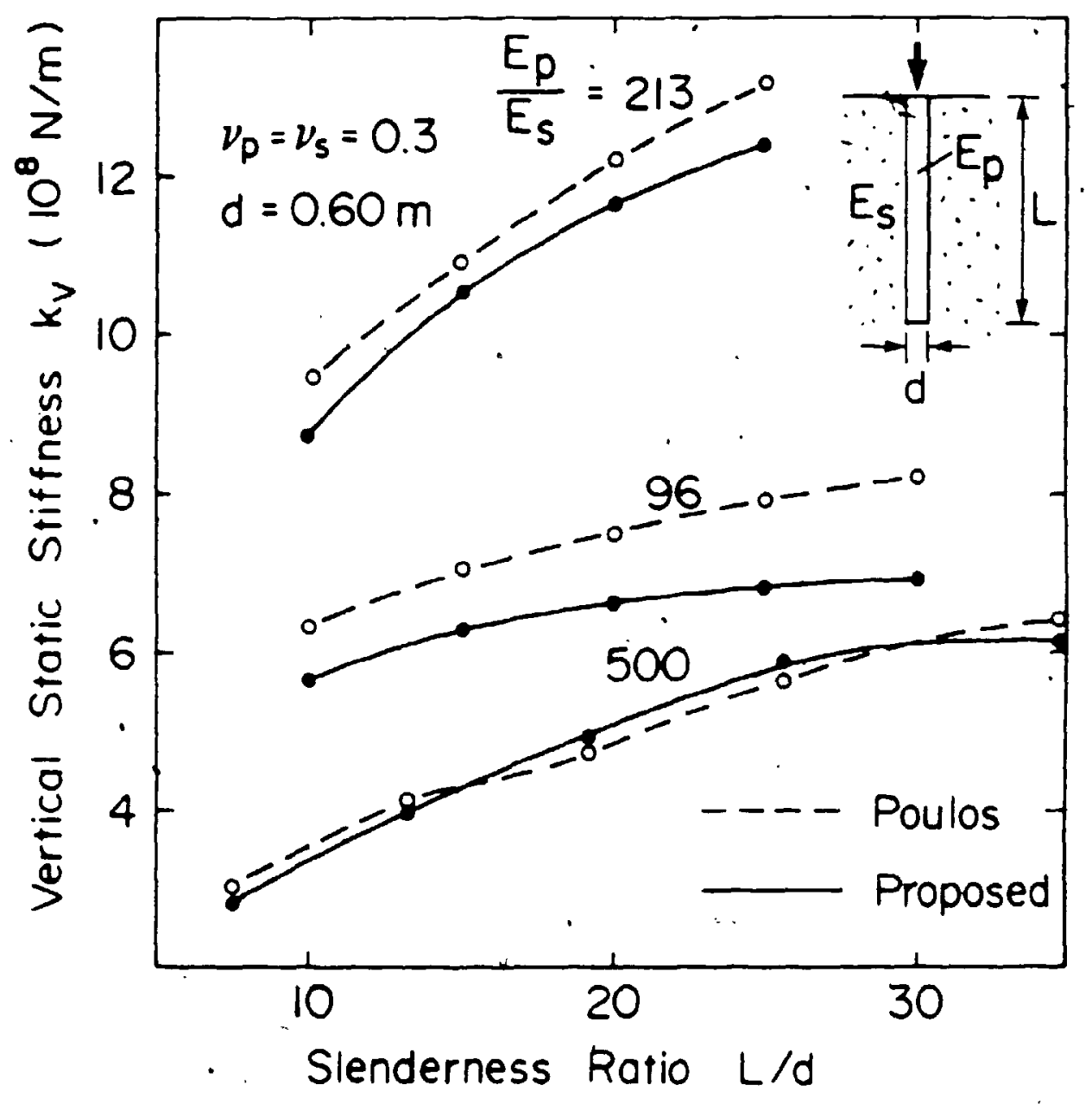

Figure 4-11: Vertical Statle Stiffness of a Single Plle (Poulos Solution Compared wilth Present Solution) 


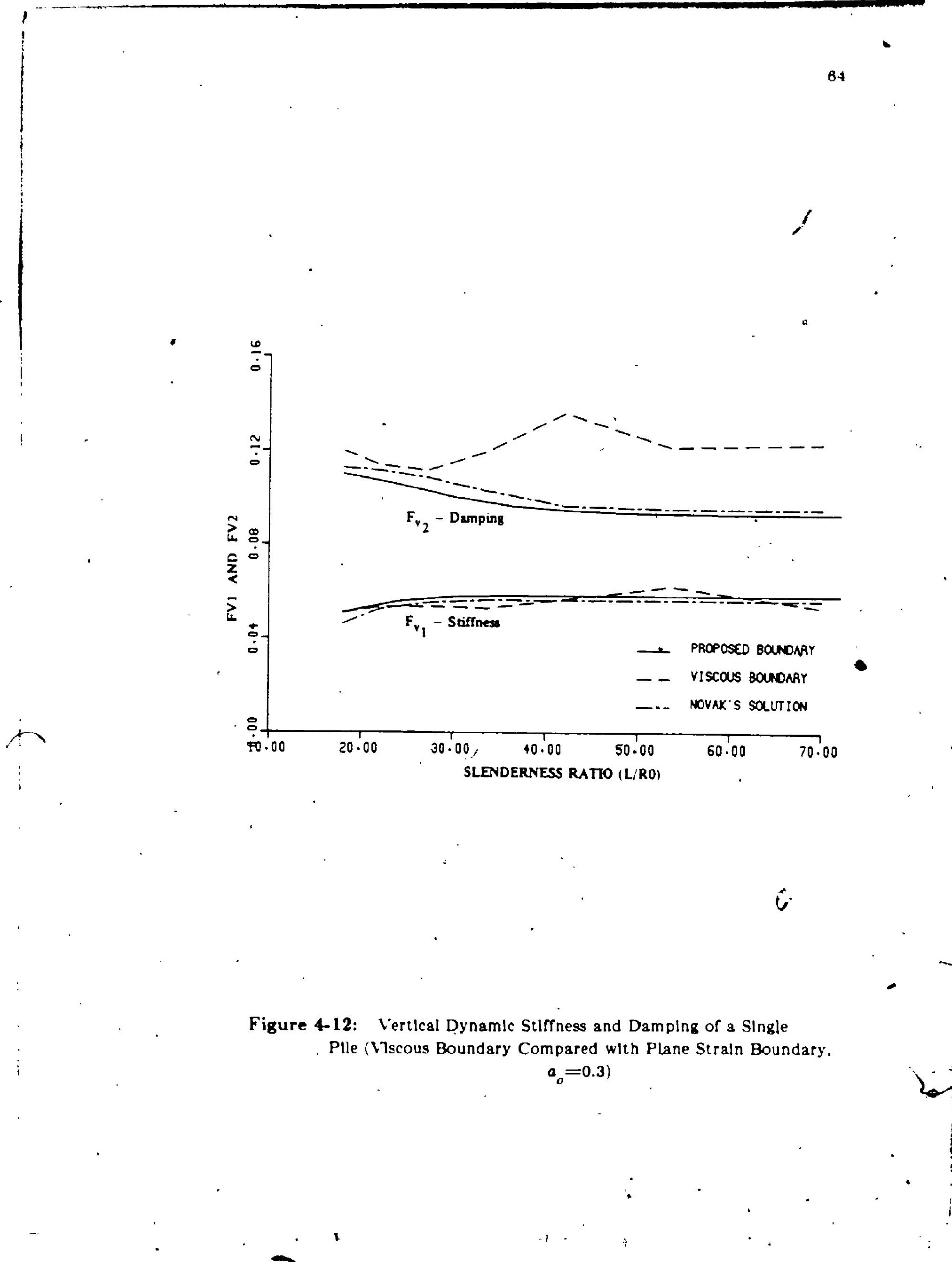



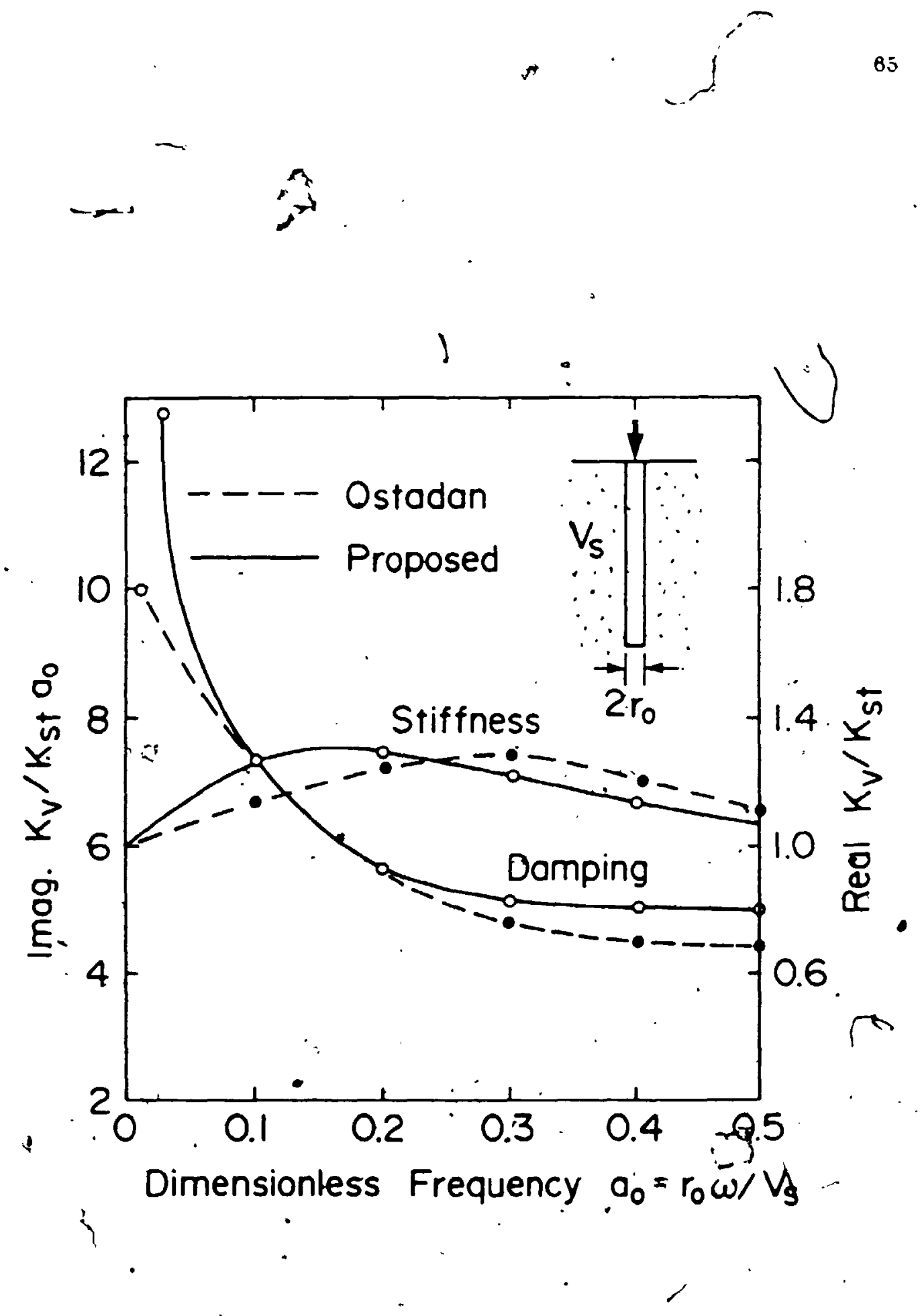

Figure 413: Vertical Stifrness and Damplng of a single Plle

(FInlte Element Solution by Ostadan Compared wilth Present Solution. $L / r_{0}=30$ ) 



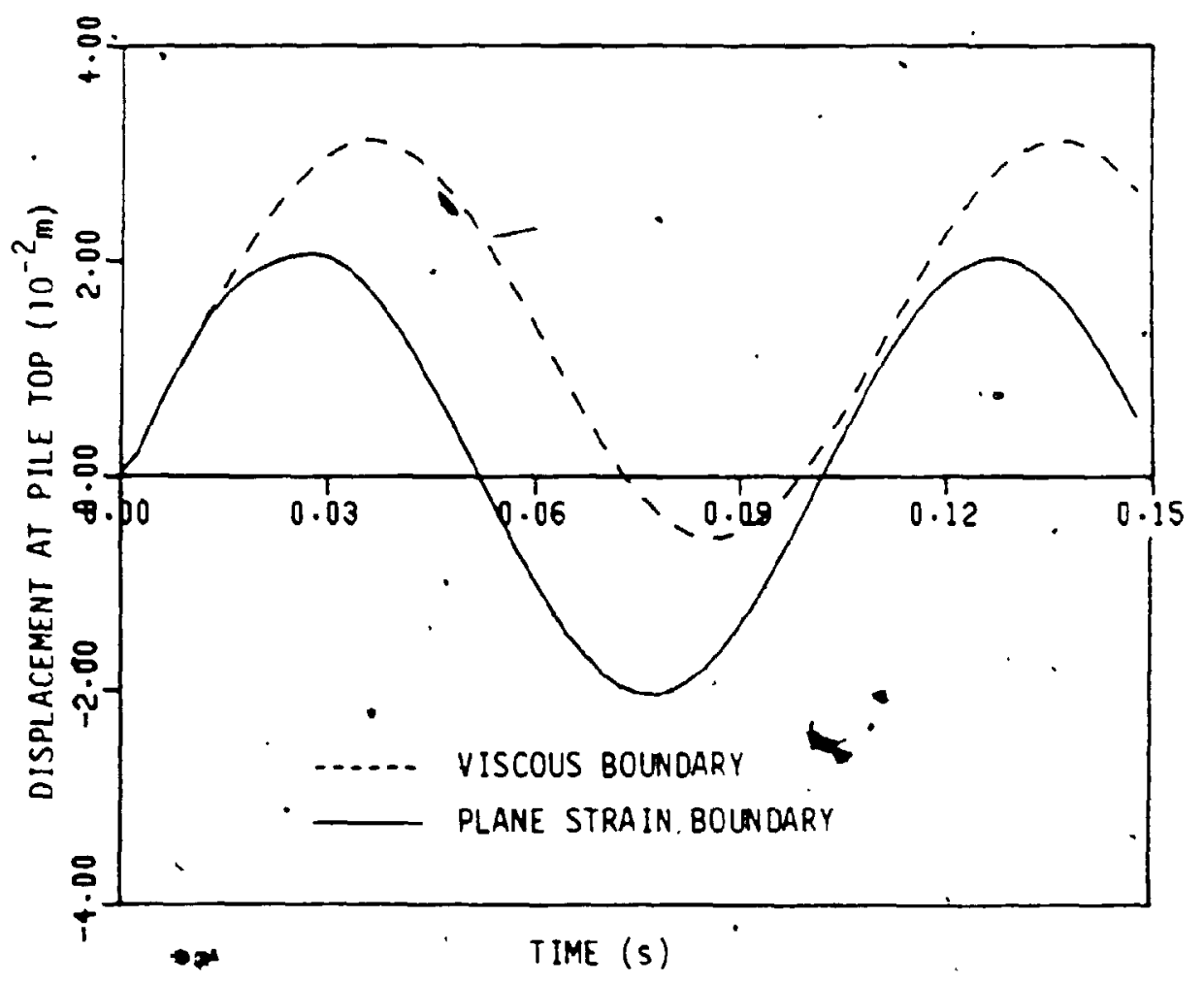

Figure 414: Displacement of Plle Tlp Subjected to a Harmonlc Load (Comparison Between Vlscous and Plane Straln Boundarles based on a tlme domaln analysls); $a_{0}=0.05$ and $L / r_{0}=24$ 
Bs

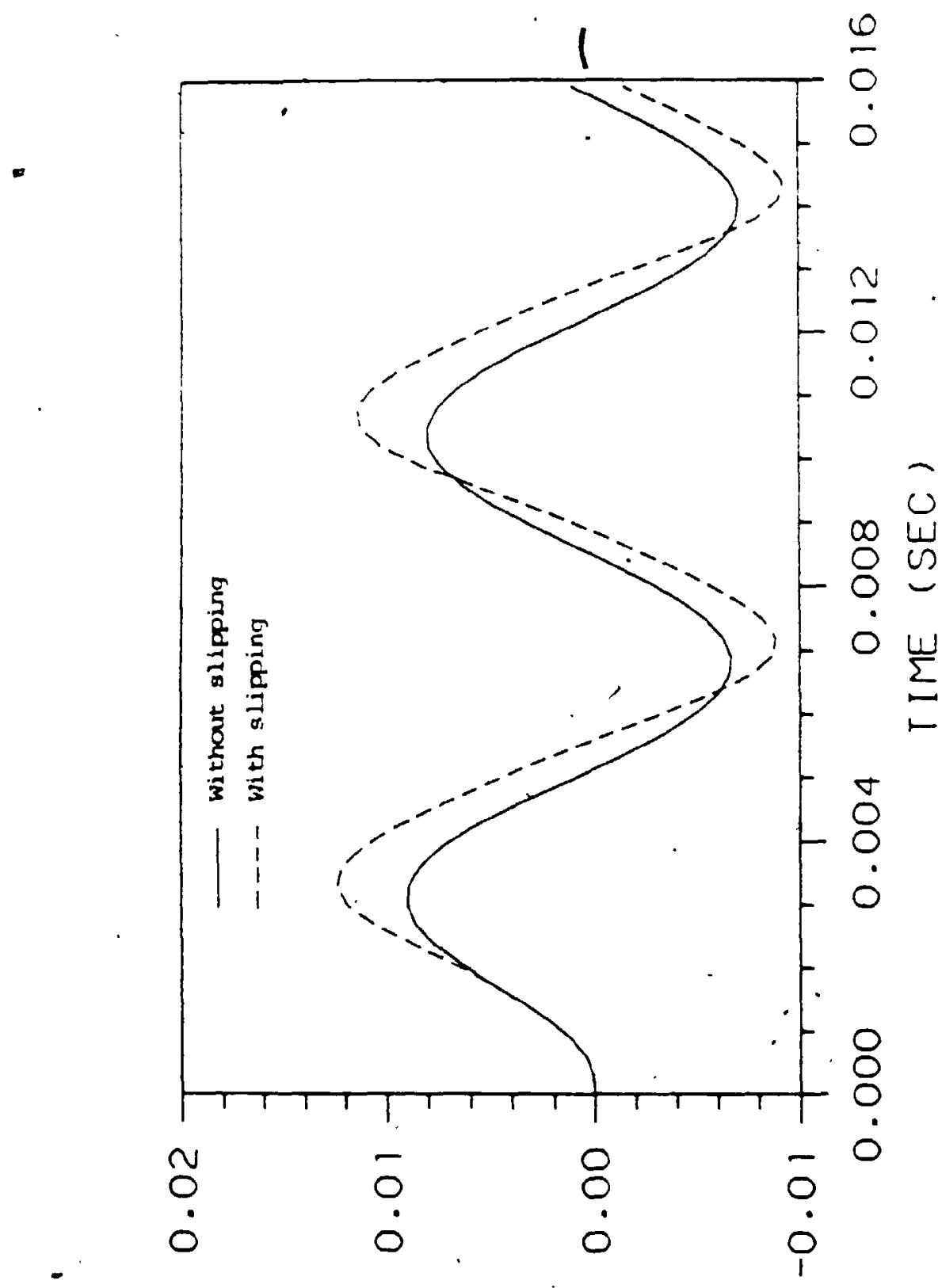

(W) $1 N \exists W \exists O \forall 7 d S I 0$

Figure 4-15: Displacement of a Plle Segment Subjected to a Harmonlc 

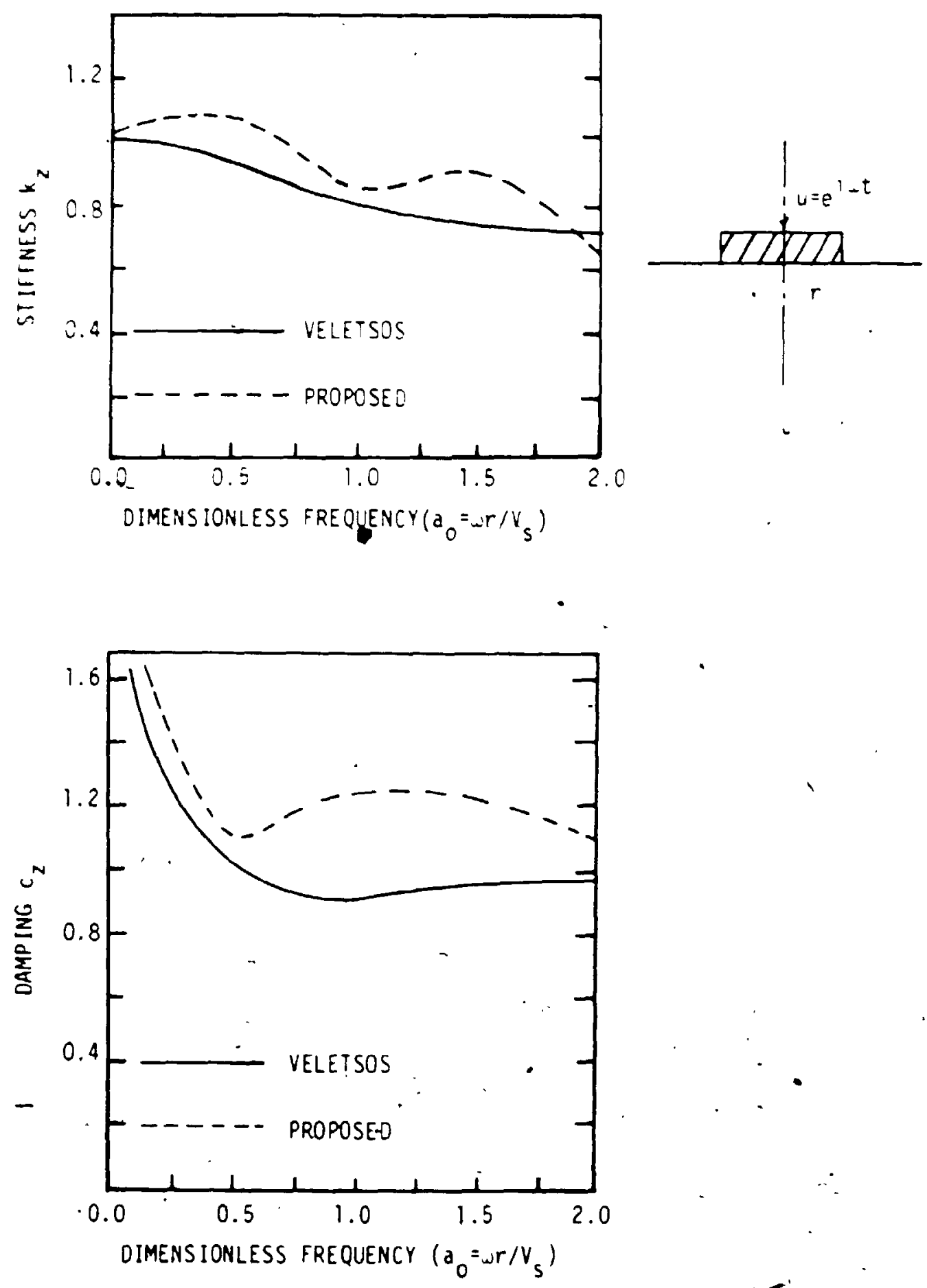

Figure 4-16: Vertica Dynamlc StIfrness and Damping of a Rigld Massless Dlsc on Halfspace 
Interface behavlour is found in 151: Goodman el al i52; developid a tho dimenstonal zero thlckness rectangular element for use in the statle analysts of rock Jolnts. In their formulation, the element stiffness is expresied In terms of the normal and shear stifrness of the Jolnt. Clough and Duncan 53 . used the same element for the analysls of retainlng walls. Zlenkleulcz et al. 54 used a simllar jolnt element in an Isoparametrle formulation Ghabouk! el a! is developed an element simllar to that of Goodman where the elomeni was considered to have non zero "thln" thlckness and used the pelathe displacempits at the inferface as independent degrees of freedom.

The effect of Interface behavlour on dynamic response of structures was studled by Tokl et 81 . $556_{i}$ who used the element developed by Goodman and considered the separation and sllding modes during strong earthquakes Desal 57.58 , and Drumm and Desal $159.60 ;$ conducted experiments to derelop constltutive models for Interface behavlour during cycllc loading. These constltutlve models were Implemented in stallc and dynamls analyses by Zaman et al. who used a thin Interface element and consldered varlous deformatton modes such as no sllp. sllp. debonding and rebonding $61 \mid$. In the present study. the thin Interface element developed by Ghaboussl et al. 155 ; is used.

\subsubsection{Formulation}

The Interface element used In this study is vertical cyllndrlcal axisymmetrlc, with elght degrees of freedom. Fig. 4.17. The following assumptlons are adopted for:derlvation of the stiffness matrix

1. Only the normal stress In the radlal directlon $\sigma$, and longltudinal shear stress $r_{r z}$ are considered in the analysis logether with the . corresponding stralns $\epsilon_{r}$ and $\gamma_{r z}$.

2. Stralns are constant along the radial directlon and vary linearly in the vertical direction. 


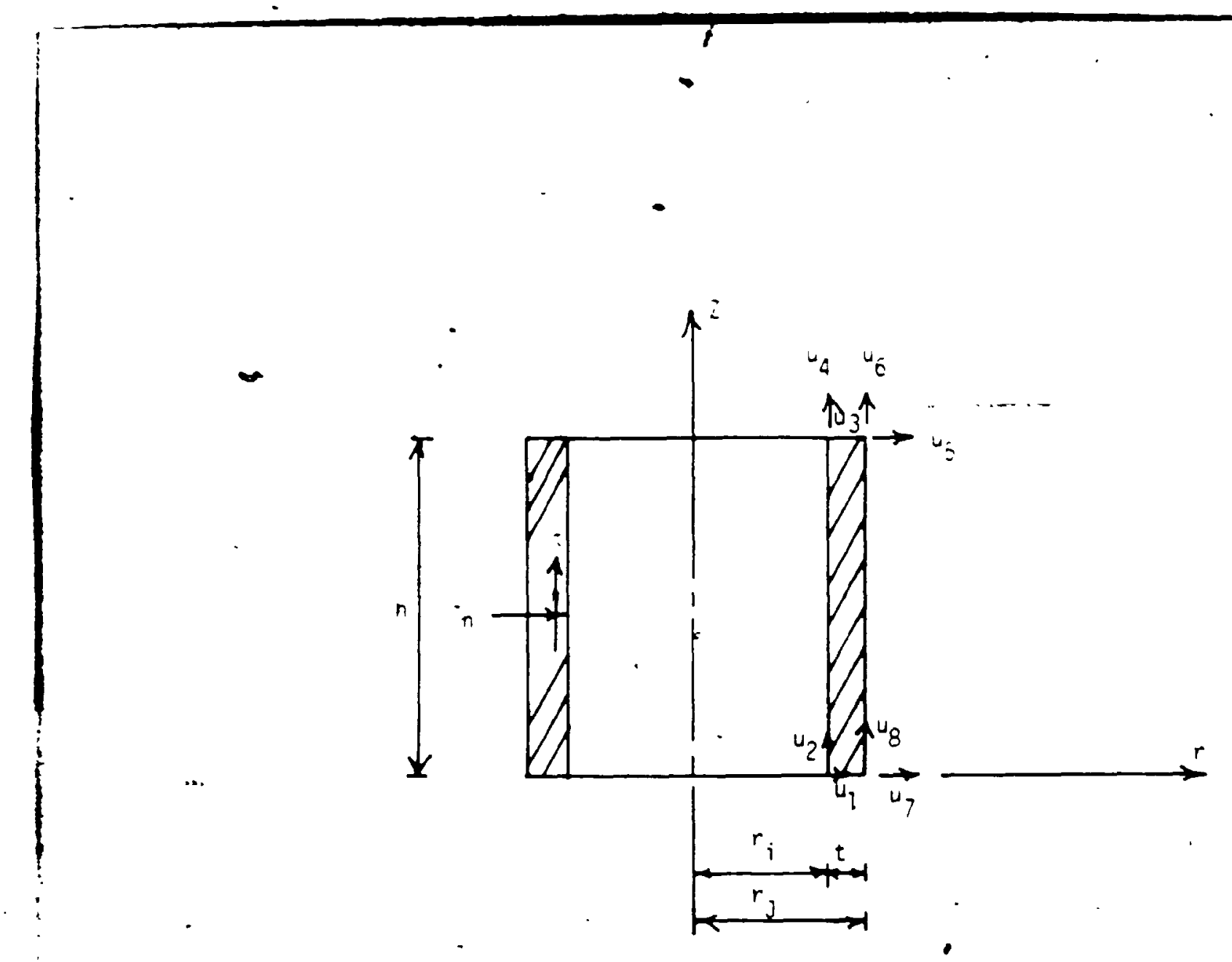

:! 
3. Shear and normal displacements are uncoupled. l.e. non dilatant behavlour of the interface is assumed.

Because the element Is very thin, the contribution to the internal virtua! work durlng deformation from the vertical and clrcumferential stresses, $\sigma$ : and $\sigma_{\theta}$. respectlvely. can be neglected which justines the nrst assumption. Although the regulat axtsymmetrlc element is assumed to have llnear stralns in both directlons. due to the small thickness of the element. It can be assumed that $\frac{d t}{d t} \approx \frac{d t}{J_{r}}$ ulthout loss of accuracy.

A Mobr-Coulomb yleld crlterton is assumed where the shear stress increases Inearly untll it is equal to the yleld stress where the element offers constant reslstance durlng further deformation untll the shear stress is reduced agaln due to negative stress Increments. Fig. 4.18. The yleld stress is glven by

$$
\tau_{y}=\alpha C_{u}+\sigma_{n} \tan 0
$$

where $C_{u}$ and $\phi$ are the undralned cohesive strength of the soll and the angle of friction between the plle materlal and soll, respectlvely and $\alpha$ is a reduction factor for driving conditions. In Eq. 4.55, $\sigma_{n}$ is the radlal norman stress at the plte soll interface. glven by

$$
\sigma_{n}=\mid \sigma-\sigma \cdot K_{0}
$$

where $\sigma$ is the radial normal stress inside the interface element that results from the driving process and $\sigma_{v}^{\prime}$ and $K_{0}$ are the effectlve overburden pressure and the coefnclent of lateral earth pressure at rest. respectlvely. Three modes of deformation are considered

A)Stick Mode: Identinèd by

$$
\sigma_{n}<0 \text { and } r<r_{y} \text {. }
$$

During thls mode, the Interface behaves elastlcally and the soll remalns in contact with the plle.

B)Slip or Sliding Mode: IdentIned by 

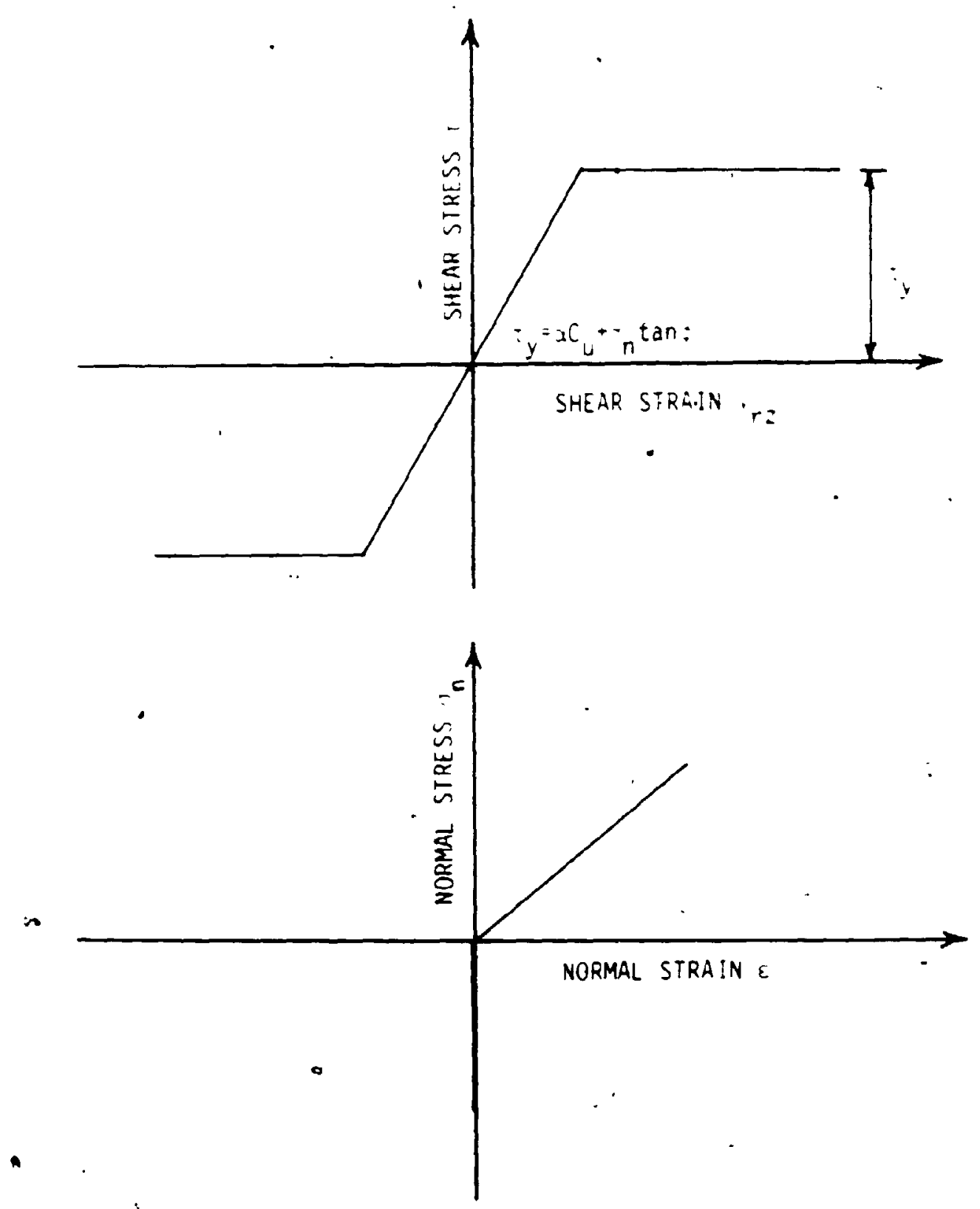

Figure 4-18: _ Stress Straln Relationshlp for Interface Behavlour 


$$
\sigma_{n}<0 \text { and } i=i_{y}
$$

In thls mode. the shear stress exceeds the yleld shear stress and the excess stresses are redistributed lieratively unill the shear stress is adjusted to be equal to the yeld stress.

Separation Mode: Identined by

$$
\sigma_{n}>0
$$

When $\sigma_{n}$ tends to exceed zero (tenslle stresses). separation between the soll and plle Is assumed and in thls mode, both the normal stresses and shear stresses have to be lteratively adjusted to zero. Tht means that the element offers no reslstance and is assumed to be non existent.

In some of the prevlous studles, the Young's modulus of the Interface element was assigned arbltrarlly high values $[55.62]$ to prevent interpenetration betheen the soll and the plle. However. the experlments conducted by Desal et al. i5l: Indlcate that the normal propertles of the Interface should be based sin the normal propertles of the soll. In the present study. the elastlc propertles of the Interface are assumed to te the same as those of the soll. A parametrlc study by. Desal et al. Indicated that the best results are obtalned when the thlckness of the Interface element is beetween 0.1 and 0.01 of that of the nelghbouring elements [51].

The Newmark $\beta$ method for time Integration is used In this-study together with the Inltlal stress method for nonllnear nnite element problęms [63]. In this method, the global stiffness matrix is assembled only once, at the beginning of calculations, assuming elastlc propertles for all the elements. Durlng the solution process, the nonlinear behavlour of the Interface elements is represented by thelr Internat reslstance. At any time $t$, the solution quantltles are known and so are the Internal reslstance forces. From the incremental equations of equllibrlum at 
time $t-\Delta t$, the Incremental displacements are evaluated and $s$ are the :ita! stresses Inslde all the elasto plastlc elements.

If the yleld stress has been exceeded in any of the elasto plastle citments. the stress value is adjusted. to the yleld stress and an tteration h performed by applying the excess forces at the corresponding node's and solving for the Incremental displacements. This process is repegted within each time step unill convergence is achleved.

The Incremental equatlons of equllibrlum at ilme $t+\Delta t$ are uritten as 45 .

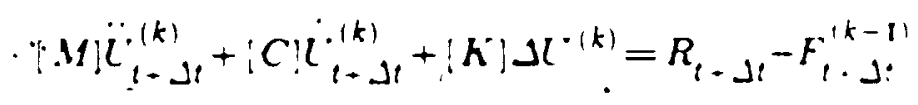

where $k$ denotes the lteration number. $t$ is time. $J t$ is the tline step and $J l^{\prime}$ is the vector of incremental displacements. $R_{t+}$, and $F_{t, j t}$ are the vectors of externa! and Internal forces, respectlvely. The following incremental relationship holds $i 45_{\mathrm{i}}$

$$
l_{t-j t}^{(k)}=l_{t-j t}^{.(t-1)}+l^{\cdot(k)}
$$

with the inltial conditions

$$
l_{t j t}^{(0)}=l_{t}
$$

and

$$
F_{t+1 t}^{(0)}=F_{t}
$$

By using the linear acceleration assumption and after some manlpulation. Eq.

- 4.57 is written as

$$
\begin{gathered}
\left(|K|+\frac{4}{\Delta t^{2}}(M)+\frac{2}{\Delta t}(C \mid) \Delta l^{(k)}=R_{t+\Delta t}-F_{t-\Delta t}^{(k-1)}\right. \\
\left.+(M) \mid \frac{4}{\Delta t^{2}}\left(U_{t}-U_{t+\Delta t}^{(k-1)}\right)+\frac{4}{\Delta t} \dot{U}_{t}+\ddot{C}_{t}\right) \\
\left.+|C| \mid \frac{2}{\Delta t}\left(U_{t}-U_{t+\Delta t}^{(k-1)}\right)+\dot{C}_{t}\right)
\end{gathered}
$$

where the unbracketed variables are understood to be vectors. Iterations ares repeated untll convergence is achleved according to the following criterion 




$$
f^{(k)}=t^{(k-1)}+\Delta t^{-1 k)}
$$

The stress increments are glven by

$$
\left.\Delta \sigma^{(k)}=\frac{E}{2 t} \Delta l_{i}^{*}+\Delta l_{5}-\Delta l_{3}^{*}-\Delta l_{1}\right)^{(k)}
$$

and

$$
\Delta_{i}^{(k)}=\frac{G}{2 t}\left(\Delta l_{8}+\Delta l_{6}-\Delta l_{4}-\Delta l_{2}\right)^{(k)}
$$

\section{3)Forces in the Plastic Elements}

$$
\left\{F_{p}^{(k)}\right\}=\int_{1}[B]^{T}\left\{\sigma_{o}^{(k)}\right\} d V
$$

where $\left\{B !^{T}\right.$ is the straln displacement matrix and $\left\{\sigma_{o}^{(k)}\right\}$ is the vector of average stresses inslde the plastlc element, i.e.

$$
\left\{\sigma_{o}^{(k)}\right\}^{T}=\left\{\sigma_{r_{0}} \quad \sigma_{\Sigma_{0}} \quad \sigma_{\theta_{o}} \tau_{o}\right\}^{(k)}
$$

The vector of average stresses is evaluated from

$$
\left\{\sigma_{o}^{(k)}\right\}=\left\{\sigma_{o}^{(k-1)}\right\}+\left\{\Delta \sigma_{0}^{(k)}\right\}
$$

and the vector of average stress Increments is given by

$$
\left.\left\{\Delta \sigma_{o}^{(k)}\right\}=\left(\frac{1}{v} \int_{l}[D] \mid B\right] d l\right)\left\{\Delta l^{(k)} \cdot\right\}
$$

The following constralnt is applled for the vertlcal stress so that It is always less than or equal to the yleld stress underneath the plle

$$
\sigma_{z_{0}}^{(k)}= \begin{cases}\sigma_{z_{0}}^{(k)} & \left|\sigma_{z_{0}}^{(k)}\right|<\sigma_{y} \\ \sigma_{y}\left|\sigma_{z_{0}}^{(k)}\right| / \sigma_{z_{0}}^{(k)} & \left|\sigma_{z_{0}}^{(k)}\right|>\sigma_{y}\end{cases}
$$

In Eq. 4.80, $\sigma_{y}$ is the vertical yleld stress underneat h the plle. The value of $\sigma_{y}$ is taken to be $N_{d} C_{u}$ where $N_{d}$ is the bearing capaclty factor for the plle tlp and is assigned a value of 9 which is the common practice In soll mechanlcs.

To check the performance of the Interface element, the response of a - vertically loaded plle subjected to harmonic load is evaluated in the time domain 
with and without the interface element. The plane strain transmitting boundary Is used in thls example and the thickness of the Interface element is taken as 0.1 of that of the nelghbouring elements. The yleld shear stress ; is assumed to be half the undralned coheslve strength of the soll. Young's modulus of the soll is evaluated as $500 \dot{C}_{u}$. Fig. 4.18 shows the plle top response for both cases. It is seen that the presence of the Interfate element increases the response of the plle.

\subsection{Example}

Due to the high computing costs or the ninite elẹment analysls, a shorter plle than that of Chapter 2 is used in thls example. The following propertles are assumed

Hammer and Capblock

Hammer mass

Cushlon stiffness

Impact Veloclty of the hammer

Plle

$\begin{array}{ll}\text { Outer dlameter } & 0.4 \mathrm{~m} \\ \text { Wall thlckness } & 0.04 \mathrm{~m} \\ \text { Denslty } & 7700 \mathrm{Kg} / \mathrm{m}^{3} \\ \text { Total length=penetraiton length } & 12.0 \mathrm{~m} . \\ \text { Young's modulus } & 2 \times 10^{11} \mathrm{~Pa} \\ \text { Polsson ratlo } & 0.2 \\ \text { Materlal damplng ratlo } & 0.01\end{array}$

Soll

Undralned coheslve strength

Density

$2 \times 10^{3} \mathrm{~Pa}$

Polsson ratlo

$1700 \mathrm{~kg} / \mathrm{m}^{3}$

$\sigma_{y} \cdot$

0.25

$8 \times 10^{4} \mathrm{~Pa}$

$8 \times 10^{\circ} \mathrm{Pa}$

The Impact of the hammer on the plle is expressed as a pulse force evaluated as . explatrod $\mathrm{n}_{f}[64]$ and is glven by..

$$
F(t)=k \frac{v_{h}}{\omega_{d}} e^{-\xi t} \sin \omega_{d} t
$$

where $k$ is the cushion stifrness. $l_{h}$ is the hammer Impact velocity, $i_{d}$ is the damped natural frequency glven by 


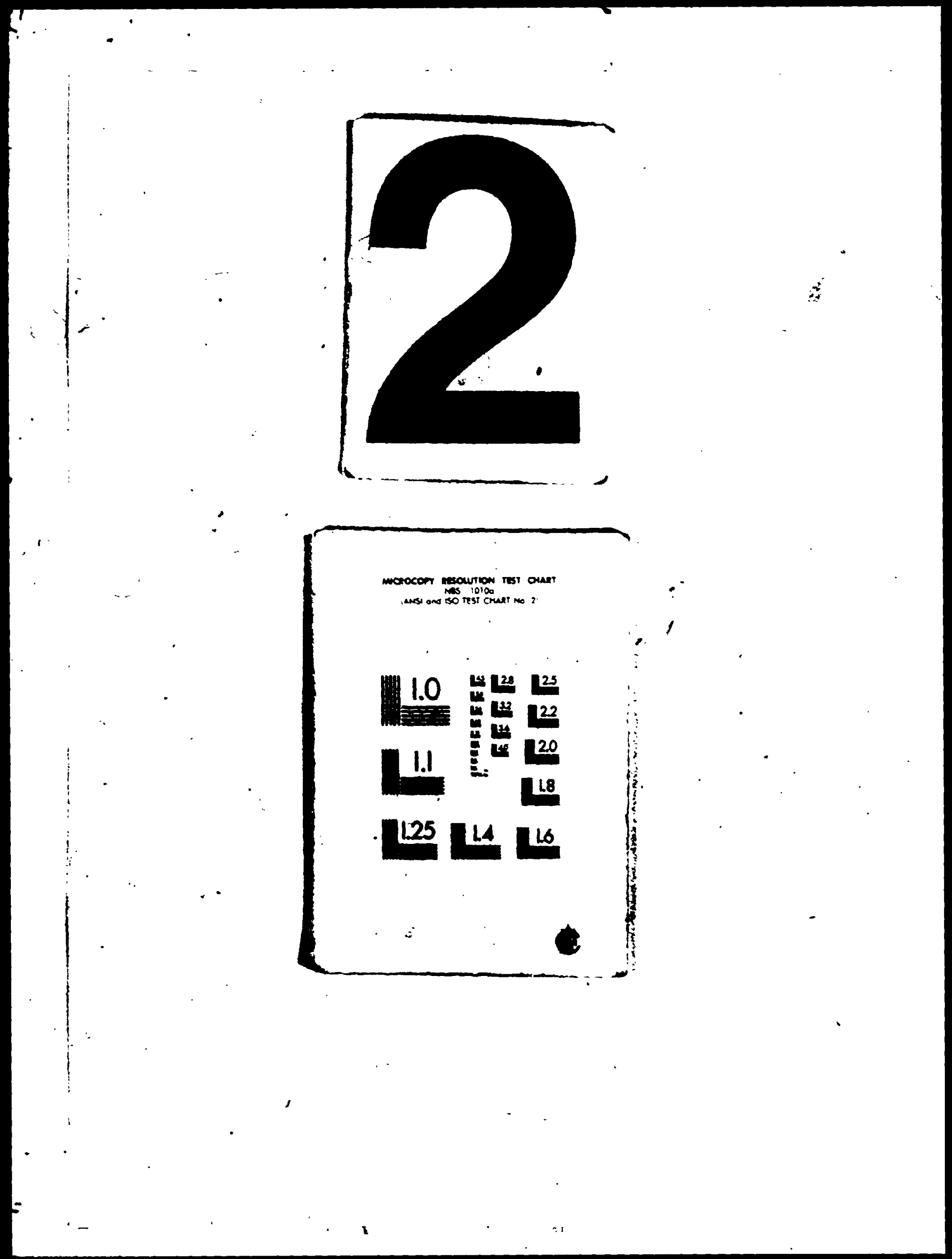


80

Y

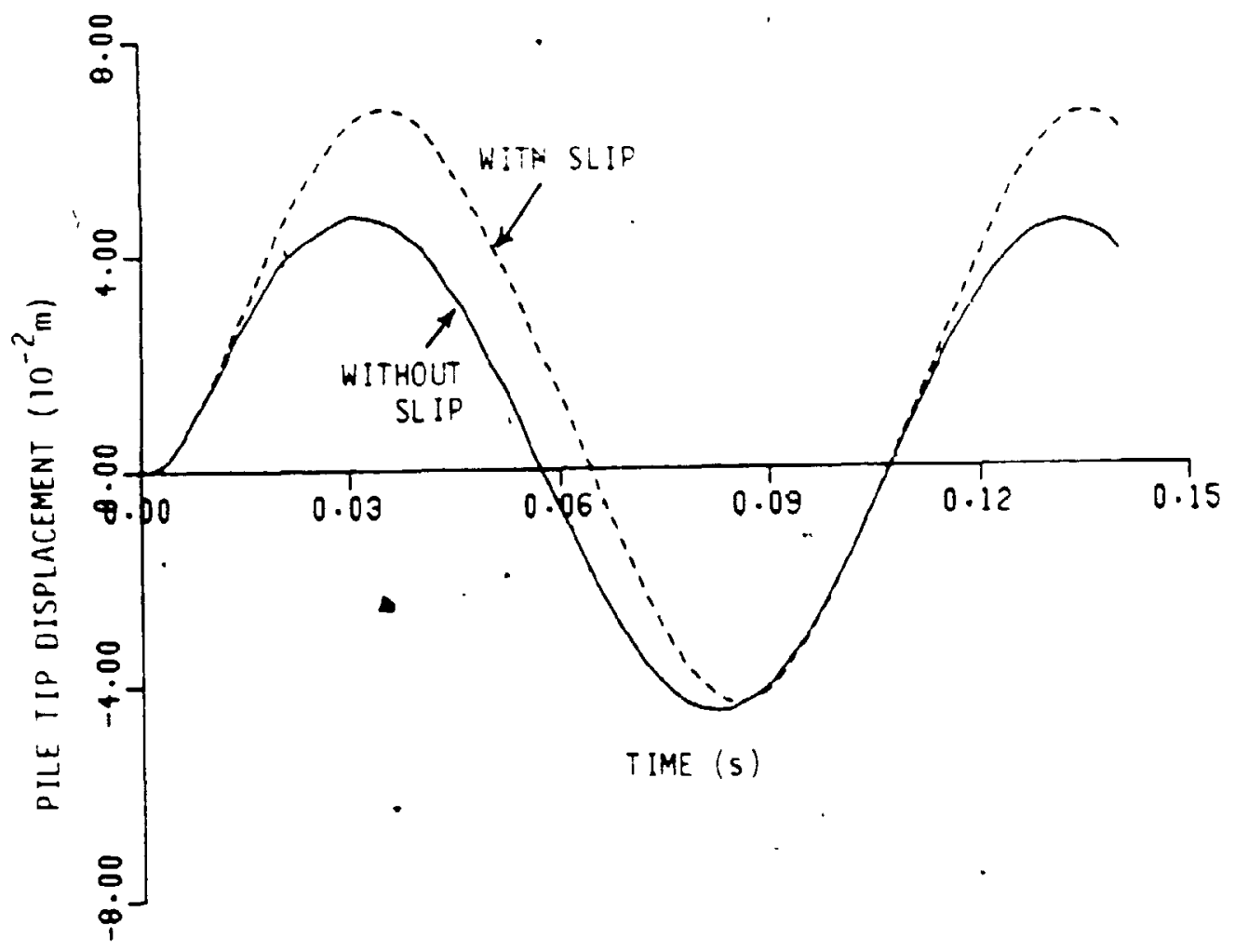

Figure 4-19: PIle Top Displacement With and Without PIle Bol Slip $\left(a_{0}=0.06\right.$ and $\left.L / r_{0}=24\right)$. 


linearly elastle. The appllcabllty of the plane strain and the vlsortis houndartem to the plle driving problem are examtned and the following conclusions emerge

1. The transmltting boundary developed in thls study which ls basid on the plane strain soll reactions can be used for statl as weil as dynamic analyses. Due to the relative Insensitivity of lts parameters io requency, It can also be used for time demaln analyol thiboundary appears superlor to the standard Iscous boundar!

2: Plle response to a harmonle load obtalned using the brow hountar! experlences a shift in the equllibrlum position whlch mishi affe: the value of the plle set if such a boundary ls usad for file drivlng analys!s.

3. The soll model used in this chapter is not sultable for pile diling

- analysls and a more reallstle model should include the soll plastlelty in the analysis.

4. Finlte element analysis of plle driving is very cosily and at least 2 orders of magnltude morexpensive than'a one dimensional analysls. A true time domaln analysls for large orrshore plles that would take the plastlc behavlour of the soll into account would Indeed be prohlbltively expenslve. Glven the physicsl uncertalntles involved. thls cost can hardly be justifled. If such analysls were to be conducted, the transmltting boundary formulated hereln-is adequate. 


\section{Chapter Five Foundation Model For Fixed. Offshore Towers}

\subsection{Introduction}

Soll-structure Interaction occurs when the foundation Is Mevible. under earthquake excltation tt occurs when the footing displacements differ from those of the far neld. This interaction is more signincant for soft soll Incluston of soll-structure interaction in the dynamlc analysts of offshore towers is escentia! as It affects the free vibration characteristics whlch have a direct bearing on the response prediction. Typlcally, considering the roundation Mexiblity in the analysls modines the natural frequencles and mode shapes and accounts for radiation damplng $[05.88 .67 ;$. These modincations are extremely Important. speclally for narrow band processes such as wave loads. since a shift in the fundamental frequency may bring lt closer to the peak frequency of the load spectrum. Furthermore. In a selsmlc event, the lower ulth-lts foundatlon wlll Interact with the surrounding soll leading to $\mathbf{a}^{\circ}$ modincation in the input selsmic signal at the base of the structure $188 j$ known as kinematlc Interaction.

- For plle supported towers, the nexlbllity of single plles is routinely accounted for in both static $\{69,70 ; 71\}$ and dynamic $[66.72 .73$; analyses. The Inclusion of Interaction betweeen Individual plles. known as plle-soll-plle interaction. is standard practlce in statle analysls $|74-77|$. Plle-soll-plle Interaction In statlc analysls may algnificantly inerease the settlement and lateral deflectlon of the superstructure [76] and reduce the bearing capaçly of a plle group. On the other hand. the infuence of dynamlc plle-soll-plle Interaction on the tower response has not been fully appreclated. 



For vertical plles with clrcular cross sectlons. the horizonial. rocking and cross stimnesses in both directions are equal. l.e.

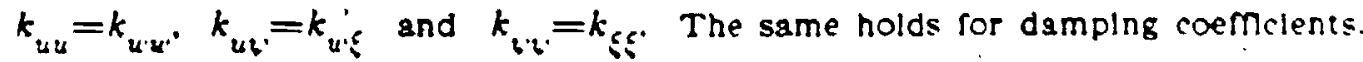
Also. the vertlcat translation and torsigral rotation are uncoupled from the other displacements.

\subsubsection{Review of Existing Solutions for Impedance Functions}

For plles with two planes of symmetry, such as clrcular plles avallable solutions for evalyating the dynamle stiffness constants of a single. plle can be categorlzed into lumped mass models $[82-85]$. contlnuum models $\left[86-90^{\circ}\right.$. Unlte element models $[48,91-94]$ and boundary element models $[95$;.

Lumped Maso Models: the plle mass is lumped into a set of discrete stations and the soll resistance is prescribed to these statlons in the form of springs and dashpots. The main advantage of thls model is lts abllity to handle nonllnearlty because the springs and dashpots can be made nonlinear as deslred. This method encounters some dimculty in choosing the approprlate nonlinear springs and dashpots propertles. However, some success bas been achleved in modeling the nonlinear spring characteristics from full scale tests by Matlock et al. [85]. The lumped mass model was employed by Penzlen et al. [82,84] who used the statlc displacement neld resulting from a single force applled at an Interlor polht of a homogeneous half space (MIIndlin's equatlon) to obtaln the soll resistance at a polnt along the plle shaft. The basje disadvantage or this fhodel is Its uabllity to account for Interaction between Indlvidual plles in its present form.

Continuum Models: these models bastcally employ the equations of motion of a llnear visccoelastlc medlum to obtaln the soll reslstance to the plle motion. Tajlml [86] consldered a frequency dependent vlscous damplng (Kelvin-lolgt model) and solved the horizontal response of a nxed head plle with a pinned tip. 


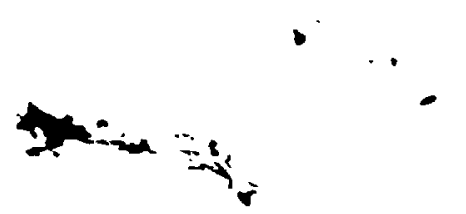

Vogaml and Norak i87.88. studied an elastic end bearing plle injergoing harmonle verstion in both the vertical and horlzontal directlons. The soll 1 assumed to be a viscolastle homogeneous medium wlih frequeni Indergentem: materlal damplng. For the tertlcal response. horlzonial displacements are assumed to be negllglbly small and so are the vertlal displarments for ino horlzonial response. Displacements and local soll reslstance are expresied as a! sum of contrlbutlons from an innnlte number of wave modes. "Below the resonant frequency (or a specinc mode) the stifrness depends hearlly on the mode number. no progresslve wave propagates in the layer and damping is all derlued from materlal damplng.

This solution agrees well with the atatic stirfness by Poulos and with the dynamlc plane straln solution 189 j for slender plles, sort solls and frequencles above the nrst natural frequency of the soll layer. It also agrees well wilth Tajlmis solution for the horizontal case, If the difference in the defintion of materlal damping is accounted for. The main drawback of this solution is the assumption of soll homogenelty and lis limitation to end bearing plles.

Kobort et al. [90] studled the vibration of an elastlc plle in a viscoelastic soll stratum overlying a bedrock subjected to a concentrated external excltatlon and to uniformly distributed bed rock motion. A simpler approach than that of Nogaml and Novak, based on soll reactlons calculated under the assumption of plane straln, was Introduced by Novak [89] who derlved the dypamic soll springs - from Baranov's equations [96].

The assumption of plane strain is accurate for an innnitely long rigld plle undergolng unlform harmonle vibration in an infnite homogeneous lajer. The soll layer is assumed to be composed of Independent in Inltesimally thin lajers extending hortzontally to Innnity. In horlzontal response no straln occurs in the vertical direction and waves propagate only In the horlzontal directlon. 
The solution was nrat formulated in terms of llnear elasilet? for an int

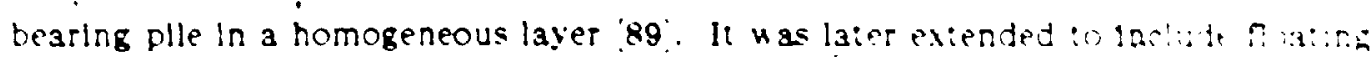

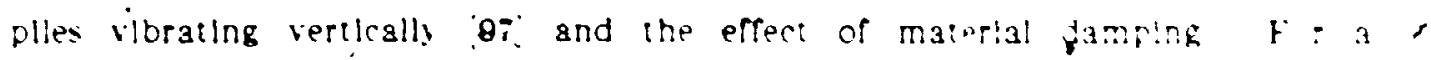

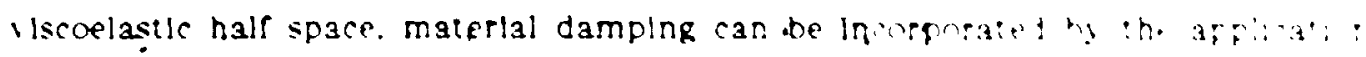

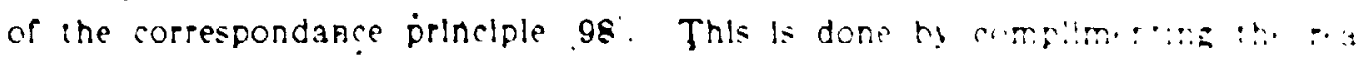
. shear modulus $G$ whit its Imaginary counierpart $G^{\prime}$ surh in.

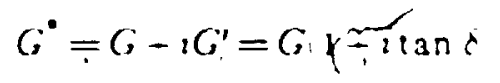

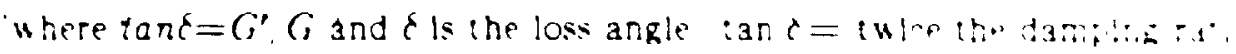

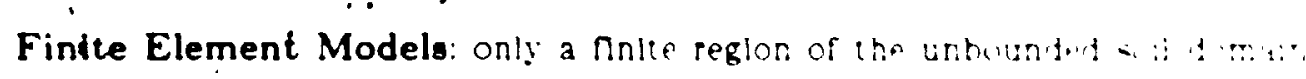
Is modeled by nnlte elements and a sultable boundary ls afplict io acomat i: energy radiation and prevent wave reflectlon Inside the modeled zon The mail: - advantage of this model is lts abilly to handle nonhomogenelty and nonilnemity. It has been successfully employed by Kuhlemeyer who used a rectangular axisymmetrlc element and a ilscous poundary to analyze vertical and lateral vibration of a single plle [91.82;. The results obiained by kuhlemeyes compare well with Poulos' results for the statlc case and with Novak's plane strain solution for the dynamlc case.

Blaney at al. $[93 \mid$ used a toroldal element with 3 degrees of freedom per node. The rar neld is represented by a seml analytle energy transmltting boundary. which is an extenslon of tho work done by Kausel et al. [40,89:. The transmitting boundary comprlses a fonslstent boundary matrlx which relates the displacements of the boundary to the corresponding reactlons and unllke a Winkler's medium. couples all the boundary nodes. Lise of nnlte elements can be avolded by modellng the plle by beam elements and moving the transmltung boundary to the plle. The method is general and varlation of the soll propertles in the horizontal direction can be accounted for by extending the modeled zone for a few elements 





\subsection{Interaction Factors}

An Interaction factor is the dimensionless (normallzed) dispiacement of one plle due to the load on a melghbouring plle. For tho Identlca! and equally loaded plles. 1 and J. F18. 5.2. the static Interaction factor $a_{i j}$ is usually defined as

$$
a_{i j}=\frac{\text { displacement of plle } i \text { due } 10 \text { load on plle } J}{\text { displacement of plle } i \text { due to its own load }}
$$

and the dynamlc Interaction factor is defined as

$$
a_{i j}=\frac{\text { dynamle displacement of plle } i \text { due to load on plle }]}{\text { statlc displacement of plle } i \text { due to lis own load }}
$$

For a vertical plle, the vertical translation is assumed to be Independent of the horlzontal translation and rotation in a vertical plane and only four different types of interaction factors need be considered. These are $\alpha_{i v}$ and $\alpha_{u u}$ for the vertical and horlzontal translations, respectively, $\alpha_{2 z}$, for rotation in a vertical plane and $\alpha_{u \psi}$ for the coupling between the horlzontal translation and rotation.

\subsection{Dynamic Interaction Factors}

To account for the effects of both stirfness and damplng. dynamlc interaction. factors are employed. The dynamlc Interaction factors are frequency dependent complex numbers, l.e.

$$
\alpha_{i j}=\alpha_{i j}(1)+i \alpha_{1 j}(2)
$$

and depend on $L / d, \rho_{p} / \rho_{s}, E_{p} / E_{s}, A_{o}$ and $S / d$ where $E_{p}, \rho_{p}, L$ and $d$ are the plle Young's modulus, density, length and diameter, respectively. $\rho_{a}$ and $E_{s}$ are thersoll density and Young's modulus, respectlvely, and $A_{0}$ is dimensionless frequency defined as

$$
A_{0}=\omega d / V
$$

where $V_{\text {g }}$ is the soll shear wave veloclty. The horlzontal and rotational Interaction factors depend also on the angle $\beta$. Fig. 5.2. between the direction of the horlzontal displacement and the line Jolning the two plles. Interaction factors are usually evaluated for the 2 llmiting cases, $\beta=0^{\circ}$ ind $\beta=90^{\circ}$. For Intermedlate angles, Randolph and Poulos [11), suggested the following relationshlp 





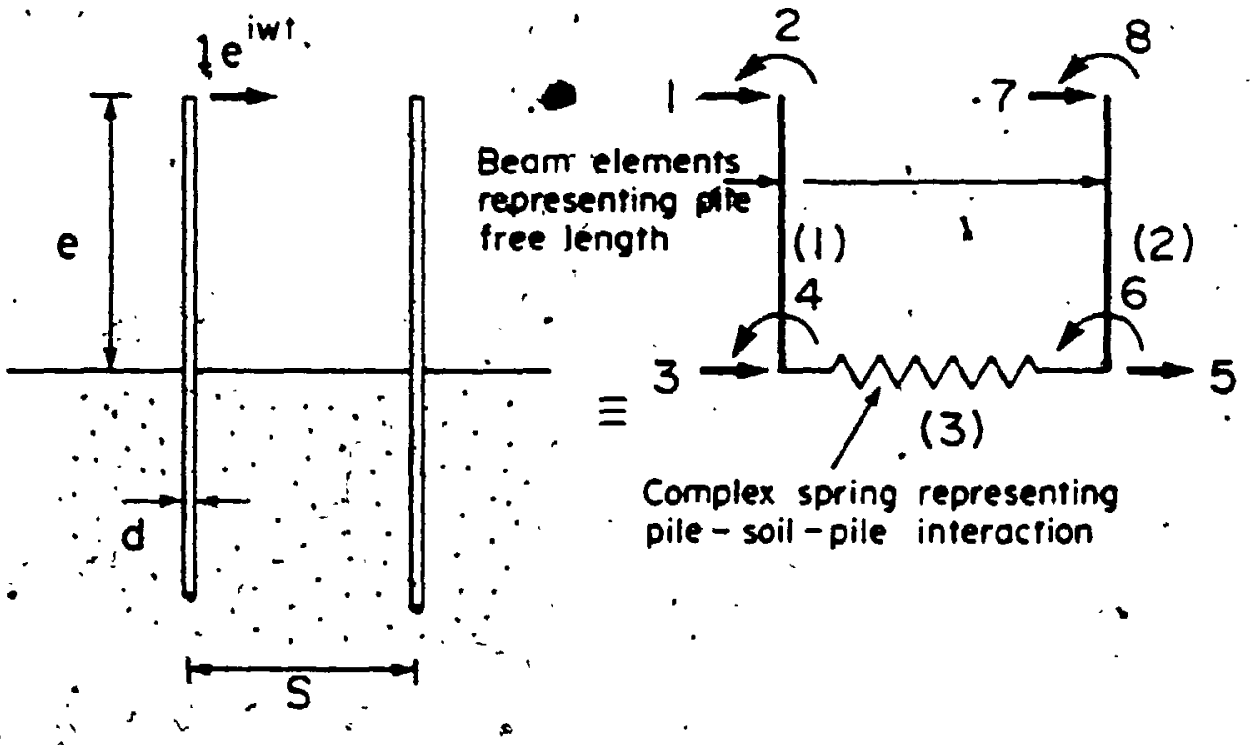

(of) Bile with free length

(b) Model of system.

Figure 5-3: Model Used to Account for Efrect of Plle Separation on Interaction Factors 
the two plles and are expressed in terms of statlc nexibllity coefnclents $T_{2}$ and - complex dynamle Interaction factors

$$
f_{11}=T_{11} \alpha_{11}
$$

Once the global stirtness matrlx $(8 \times 8)$ is assembled. a unit harmonic horizontal load and moment are applled, at different frequencles. at d.o.f. 1 and 2. The corresponding displacements at d.o.f. 7 and 8 . normalized by the statle nexibllity of the plle with free length, are the Interactlon factors. The dyamic Interaction factors of Kaynla and Kausel [103] are substltuted for $\alpha_{i j}$ In Eq. 5.17. An Interpolation scheme slmilap to the one described earller is employed to evaluate the Interaction factors for $\&$ free length at intermedlate values of $A_{0}$ and $S / d$.

Figs. 5.4 and 5.5 show the variation in the Interaction factors $\alpha_{u}{ }^{\circ} \alpha_{u t}$ and $\alpha_{i,}$ with trequency for $\beta=0^{\circ}$ and $90^{\circ}, ' S / d=2$ and three different values of $e / d$. The varlations in the same Interaction factors with the spacing ratlo $S / d$ is shown in Flgs. 5.6 and 5.7. It can be seen from Figs. 5.4 to $5.7^{\circ}$ that the absolute values of both the real and imaginary partsoof the Interaction factors are reduced by the presence of a free length. This reductlon increases with the Increase in the plle separation ratlo $\mathrm{e} / \mathrm{d}$. For the real part. the reductlon is largest at $A_{\nu}=0$. and for the Imaglnary part, the reduction Increases with dimensionless frequency $A_{a}:$. In Figs. 5.6 and 5.7. the varlations in the Interaction factors with the spacing ? ratlo show a drooplng trend; however, for higher frequencles these varlations may show an oscllatory trend (112). Whlle the presithce of a free length increases the single plle nexibllity, It decreages the interaction factors. These two effects counteract and the net effect of pile separation on the plle gronp may be smaller than Its efrect on a single plle. 


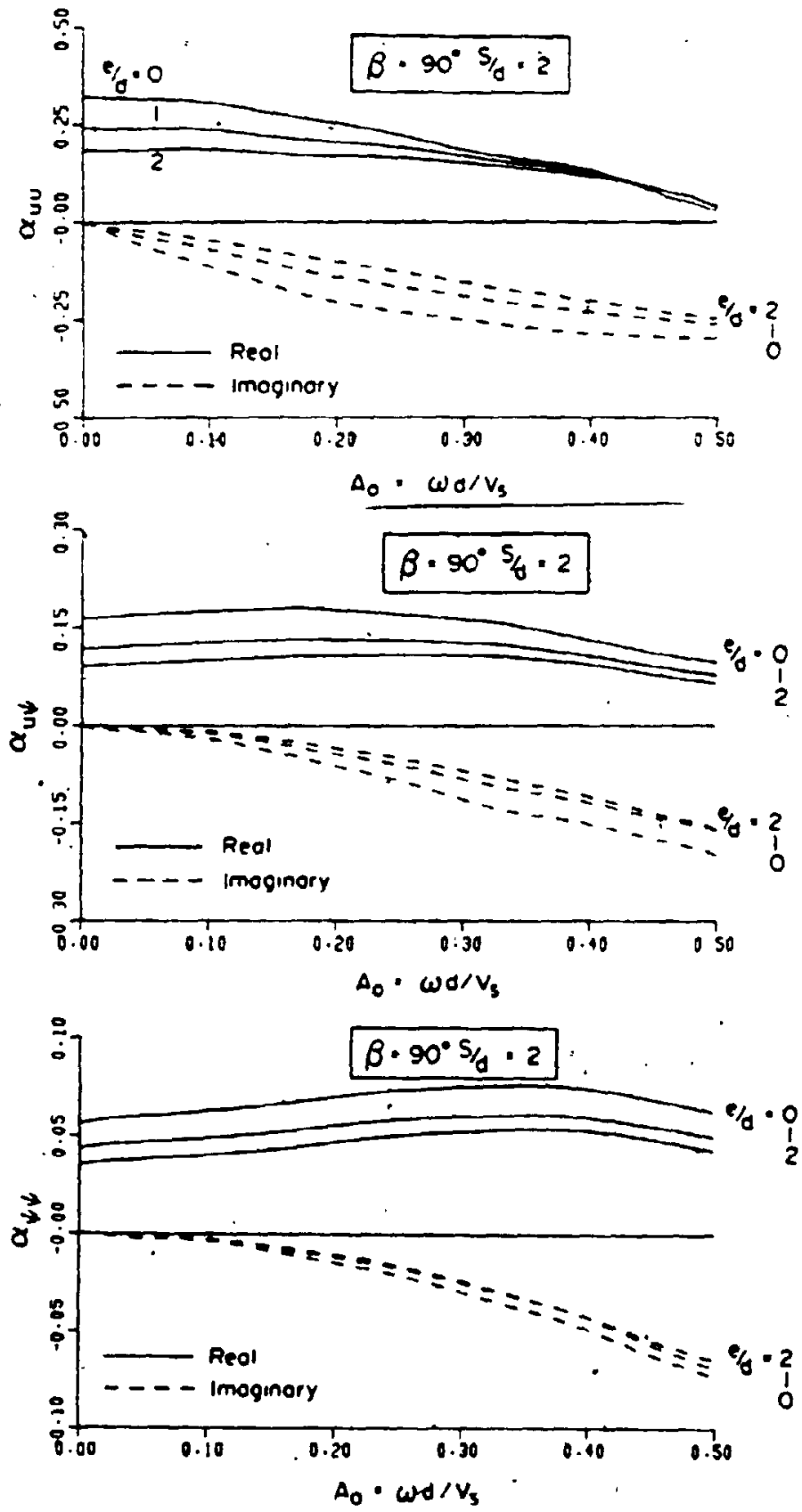

Figure 6-6: Varlation In Interaction Factors $\alpha_{u u}, \alpha_{u v}$ and $\alpha_{\text {in. }}$ with Plle Separation Ratlo $(e / d)$ and Dimensionless Frequency $\left(A_{1}\right)$ for

$$
S / d=2 \text { and } \beta=90^{\circ}
$$


$-1$
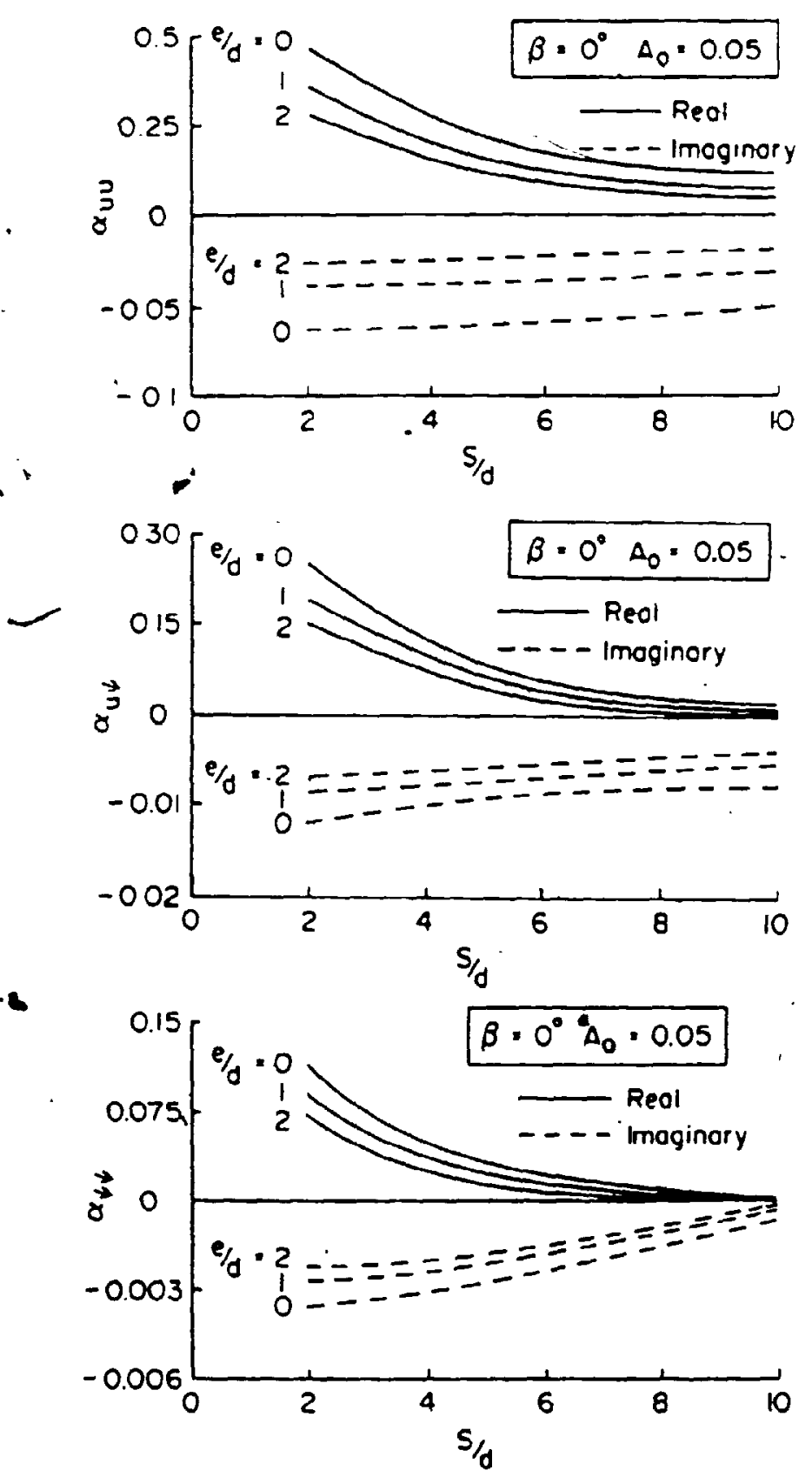

Figure 5-6: Variation In Interaction Factors $\alpha_{u u^{\cdot}} \alpha_{u t}$ and $\alpha_{u, .}$ with Plle Spacing Ratlo $(S / d)$ and Separation Ratlo $(e / d)$ for $\beta=0^{\circ}$ and $A_{0}=0.05$ 



\subsection{Foundation Stiffness Matrix}

The complex foundation silmness matrlx $k_{b}$ is obialned as ihn invere if the complex foundation Mexibllity matti $F_{b}$; l.e.

$$
K_{b}: F_{0}^{-1}
$$

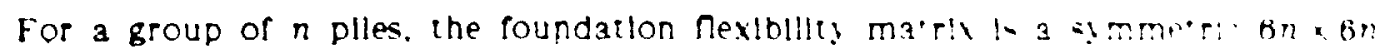
mattix

$$
F_{h}=\left(\begin{array}{ccc}
f_{11} & f_{11} & f_{1} \\
f_{n 1} & f_{n} & f_{n} \\
f_{n 1} & f_{n:} & f_{n .}
\end{array}\right)
$$

where each of the dlagonal submatrices: $\int_{i z}$ is the inverse of the single plle $6 \times 6$ complex stiffness matrix. Eq. 5.3. The off diagonal submatrlces if $i j$ represent the Interaction between the degrees of freedom at the heads of plles $z$ and . 1.e.

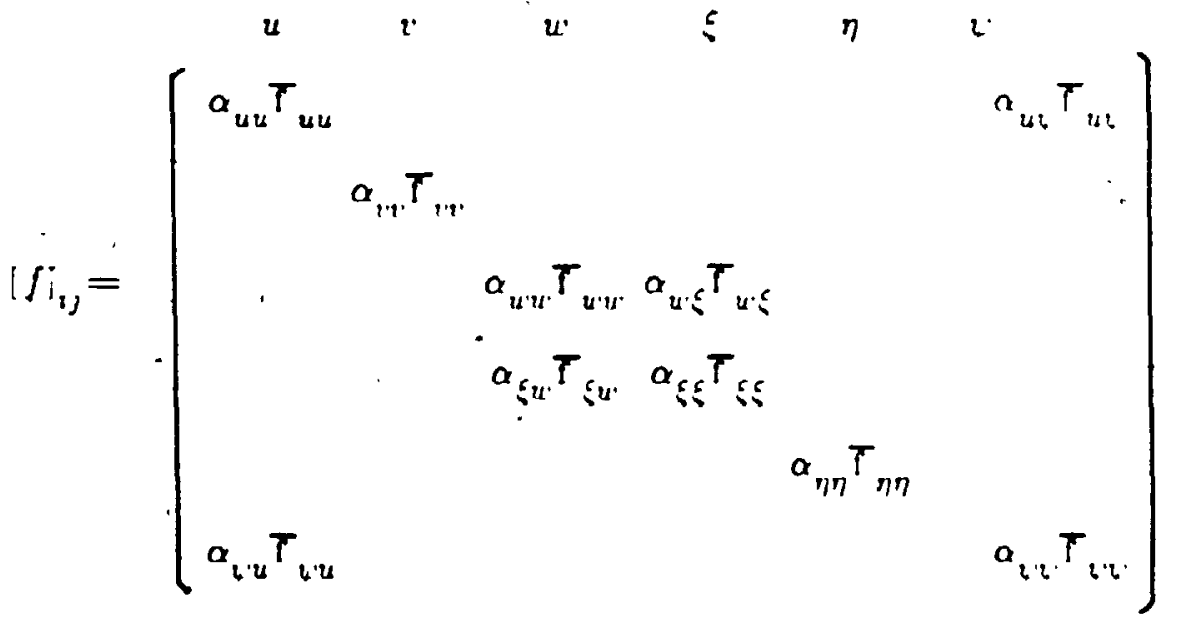

In Eq. 5.20, $\alpha_{i},-s$ are the complex dynamlc interactlon factors and $T_{i j}$, $s$ are the statlc nexibllity coefnclents. The interaction factor $\alpha_{\eta \eta}$ which accounts for plle twisting is usually very small and is neglected. In standard solutlons. pille-soll-plle Interaction is neglected and consequently the off diagonal submatrices glven by Eq. 5.20 are absent from Eq. 5.18. 
Each of the tower maln legs is supported elther by a large dlameing single plle. Flg. 5.8. or by a plle cluster, Flg. 5.9. When each of the main legs is supported by a single plle. the foundation system is a nexlble one where the displacements of plle heads vary from one plle to another. On the other hand. when each of the $r$. legs is supporied by a plle cluster. piles of the same clusier are connected by a rigld cap which controls the displacements of all plle heads. In thls ease. each plle cluster is represented as one node in the space frame modei and the stiffness constants of such a cluster are evaluated by imposing the proper boundary conditlons. In both cases, after evaluating the stiffness constants of the supporting foundation for each maln leg. the Interaction between these supporting foundatlons should be accounted for.

\subsection{Pile Group Impedance Functions}

With the foundation Nexlbllity matrix established. Eq. 5.19. the group Impedance functions for $n$ piles connected by a rigld cap can be formulated by Imposing the propef boundary condltions for each displacement mode.

\section{- 5.6.1. Vertical Group Stiffness}

For vertlcal clrcular plles, vertical dlsplacements are uncoupled. from horizontal displacements and rotations in a vertical plane. Thus it is computationally more efnclent to assemble the group vertical nexlbllity matrix separately from that of the horlzontal displacements and rotations. The compatlbllity equations are written as

$$
T_{i v}\left[\int\right\}_{1}\{P\}_{l}=\{v\}
$$

where $\{P\}_{V}$ and $\{v\}$ are the vectors or vertlcal forces and displacements at Indlvldual plle heads, respectively. $|f|_{I}$. Is the Interaction matrlx of the vertical displacements, written as 


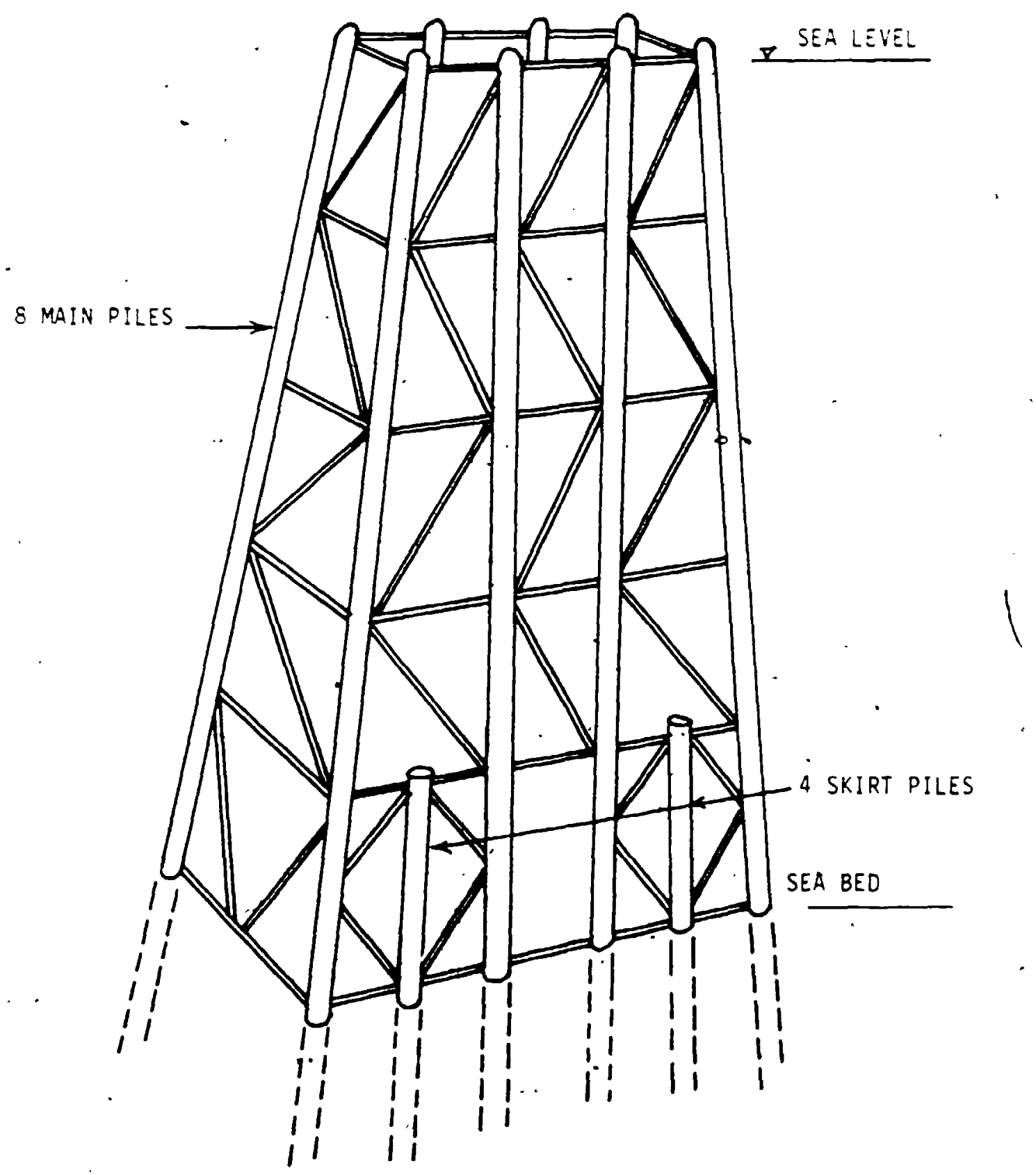

Figure 5-8: Offshore Tower Supported by a Group of Widely Spaced PIles 


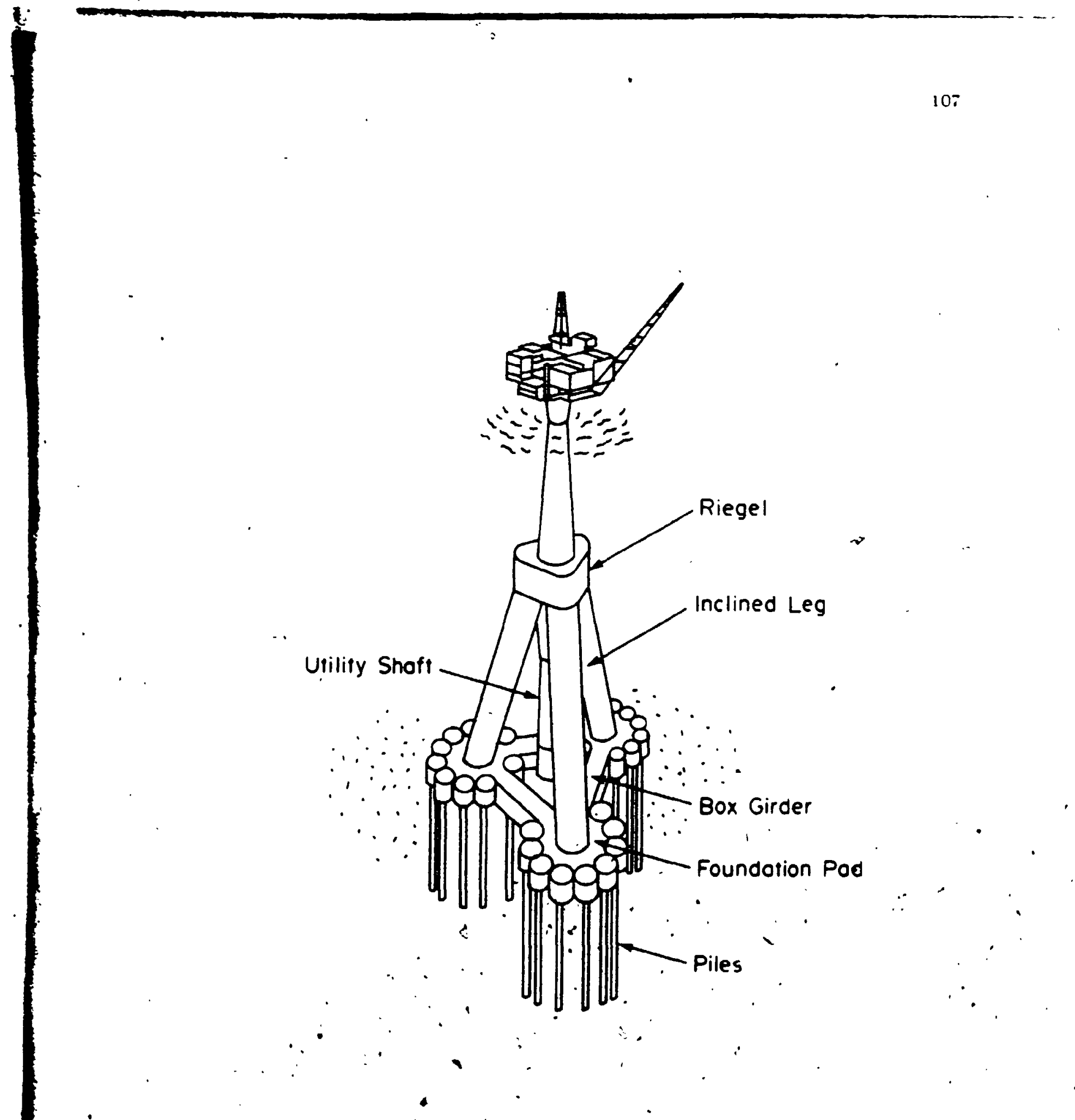

.Figure 5-9: Schematlc of Gravlty Tower Supported by a Group of.Plle Clusters 




$$
i_{i z j}=\left(\begin{array}{ll}
3_{i j u}^{u u} & 3_{j i}^{u \cdot} \\
3_{i j}^{i u} & 3_{i j}^{i z j}
\end{array}\right)
$$

where

$$
f_{r}=f_{r} / T_{u u}
$$

and

$$
\beta_{i j}^{T}=\left(T_{r} / T_{u u}\right) \alpha_{i j}^{r}
$$

In Eqs. 5.33 and 5.34. $f$, are the dynamlc nexlblllty coefnclents and $r$ stands for $u u, v$ or $u v$ indlcating the horlzontal translation. rocking or coupling, directions. respectlvely.

Horizontal Stiffness: The boundary condilions are. Flg. 5.10. $u_{1}=1$ and $\psi_{i}=0$ for $i=1 \cdots n$. The horlzontal force on plle $i$ is

$$
H_{i}=\mathrm{k}_{u u} \sum_{j=1}^{n}{\stackrel{H}{i_{2 i-1.2 j-1}}}_{!}^{H}
$$

where $\bar{k}_{u u}=1 / T_{u u}$ is the horlzontal stalic stimness coemclent for a plnned head plle and $e^{H}$ are the complex elements of $|f|_{\|}^{-1}$; hence the horlzontal group stiffness becomes

$$
K_{u u}^{G}=\overline{\mathrm{k}}_{u u} \sum_{i=1}^{n} \sum_{j=1}^{n} c_{2 i-1.2 j-1}^{\prime \prime}
$$

In Eq. 5.36, the summation extends over those elements of $|f|_{\|}^{-1}$ corresponding to the horlzontal forces assoclated with horizontal displacements. l.e. elements at positlons $2 i-1.2-1$.

Rocking Stiffness: the boundary condltions are. Fig. 5.10, $v_{1}=1, v_{1}=1 \times x_{1}$ 


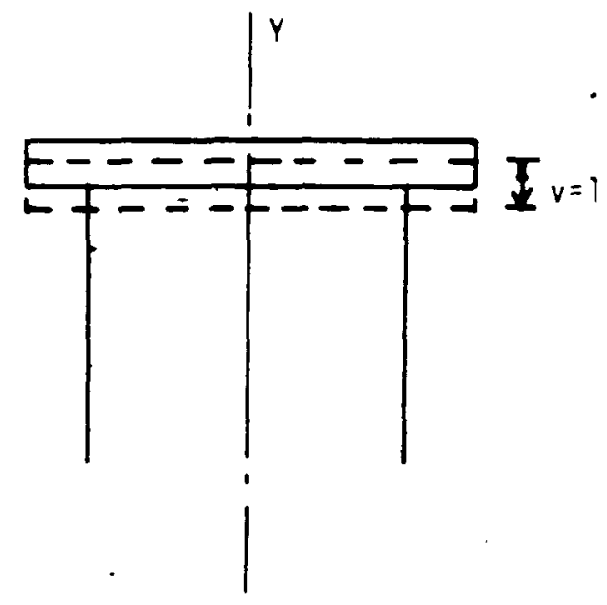

A) VERTICAL

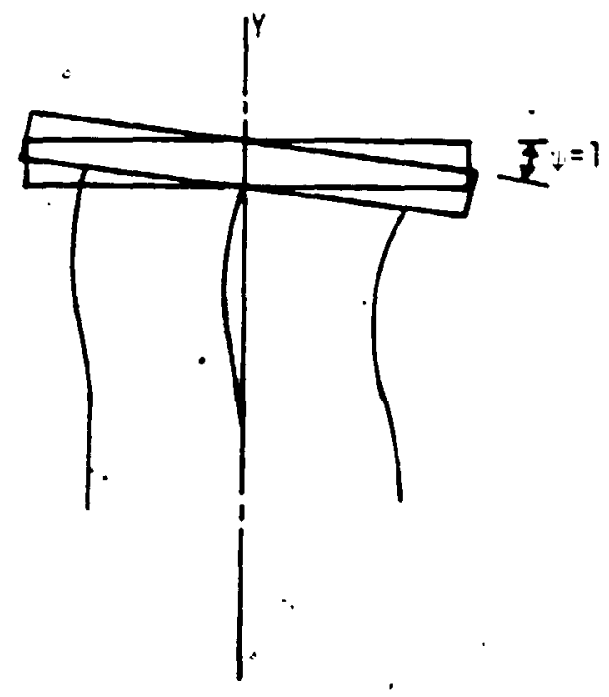

C) ROCKING

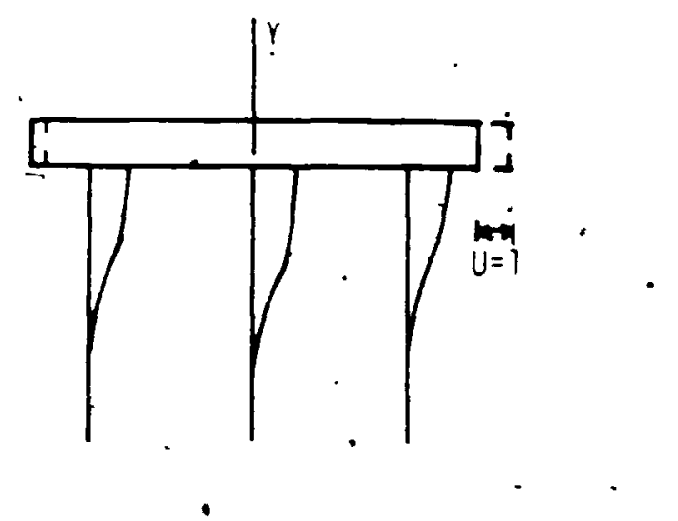

B) HORIZONTAL

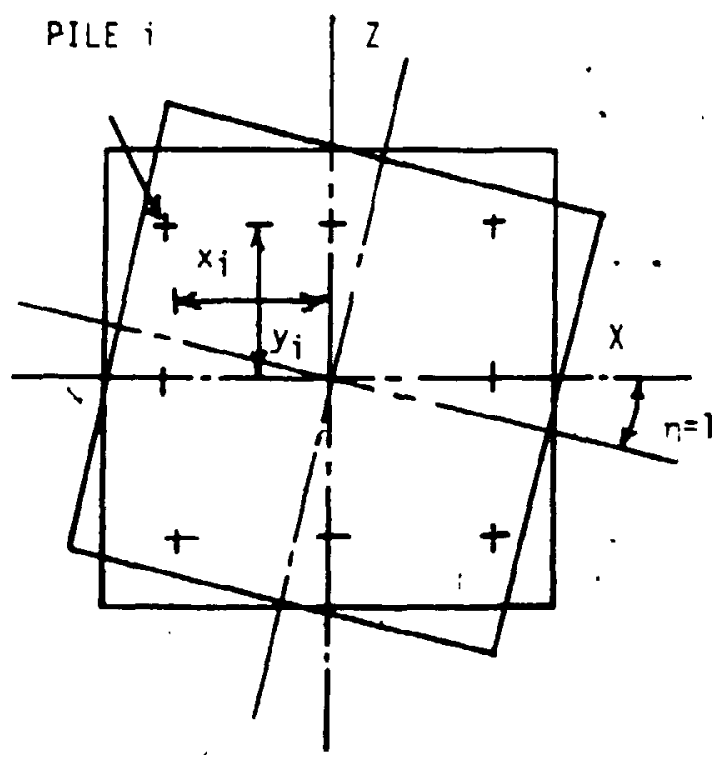

D) TORSION

Figure 5-10: Boundapy Condltions for Evaluating Plle Group Surrness Constants 

The group cross stimness is the sum of all horizontal forces on the plle heads and thus is

$$
K_{u i^{*}}^{c}=\bar{k}_{i u} \sum_{j=1}^{n} \sum_{c_{2 i-1,2 j}^{\prime \prime}}^{H}
$$

\subsubsection{Torsional Stiffness}

The torque required to iw/st indlvidual plles is small compared to that resulting from horizontal forces assoclated with a unlt rotation. A unit rotation $\eta=1$ is Imposed on the whole plle cap. Fig. 5.10. resulting in the folkowing boundary condlitions

$$
u_{i}^{s}=r_{i} \sin \theta=z_{i} \quad ; \quad \psi_{i}=0 \text { for } i=1 \cdots n
$$

and

$$
\dot{u_{i}}=r_{i} \cos \theta=x_{1} \quad: \quad \xi_{i}=0 \text { for } i=1 \cdots n
$$

where the superscrlpts $x$ and $z$ Indrate the directions of the superscripted varlables. Applying these boundary conditions to Eq. 5.27 for each of the $\mathrm{X}$ and $\mathrm{Z}$ directlons glves the horizontal forces at plle $i$ as

and

$$
H_{i}^{2}=\mathrm{k}_{u \otimes} \sum_{j=1}^{n}\left(\epsilon_{2 t-1.2 \jmath-1}^{H}\right)_{x} z_{j}
$$

$$
H_{i}^{2}=\mathrm{k}_{u u} \sum_{i=1}^{n}\left(\epsilon_{2 i-1,2 j-1}^{H}\right)_{i} x_{j}
$$

where $\left(\epsilon_{i j}^{\prime \prime}\right)_{x}$ and $\left.\left(e_{i j}^{\prime \prime}\right)^{\prime}\right)$ refer to the complex elements of $\left[\int\right]^{-1}$ for the $\mathrm{x}$ and $\mathrm{z}$ directlons respectlvely. These two horlzontal forces produce the moments

and

$$
M_{i}^{I}=\overline{\mathrm{k}}_{u u_{i}} \sum_{j=1}^{n}\left(c_{2 i-1.2 j-1}^{\prime \prime}\right)_{s} z_{j}
$$

$$
M_{i}^{i}=\mathrm{k}_{u u} x_{i} \sum_{j=1}^{n}\left(e_{2 i-1,2 j-1}^{\prime \prime}\right)_{z}{ }^{\prime},
$$



Fig. 5.11 shows the connguration of the three groups where a rigld massless cap and nxed head plles are assumed. The complex group stiffness is calculated. at different frequencles. using Eq. 5.26 for the vertlcal direction and Eq. 5.36 for the horizontal direction. :

Figs. 5.12 to 5.14 show the varlation in group emclency ratlo for both stifrness and damplng with frequency for the three groups. The GER for stlffness Is mostly less than one except for the smaller groups for which the vertlcal stifrness can be seen to exceed unlty at higher frequencles. GER equal to one Indicates no Interaction effects whlle GER less than one indlcates reduction in group stifness or damping. The reduction in group stifrness is partlcularly large for the group of 10 plles for which it decreases with frequency up to about $A_{0}=0.35$. For damping. the GER may exceed unlty Indicating amplincation of energy disslpation through plle Interaction.

\subsection{Conclusions}

Dynamlc Interaction factors for plle-soll separation are evaluated using the dynamic Interaction factors produced for fully embedded plles by Kaynla and Kausel. PHe group stirtness constants are formulated for' all vibration modes and the group emclency ratlos for the vertlcal and. horizontal vibration of 3 plle groups are calculated at different frequencles. The following concluslons emerge:

1. The effeci of plle-soll separation (gapplng) on dynamlc Interaction is to decrease the absolute values of both the real and Imaginary parts of the interaction factors.

2. The reduction in Interaction factors Increase with the plle separation ratlo $e / d$.

3. Dynamic plle-soll-plle Interactlon reduces the stiffness and Increases the damping of plle groups whlch may have a profound effect on tower response to dynamic loads.

4. Plle group propertles vary, with frequency more strongly than those of a single plle. 


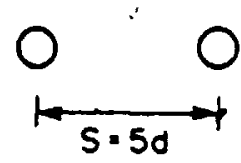

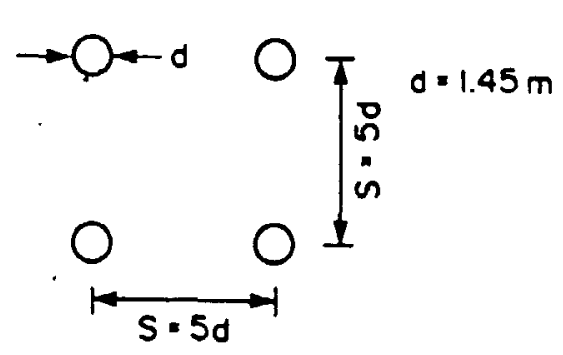

(b) 4 PILES

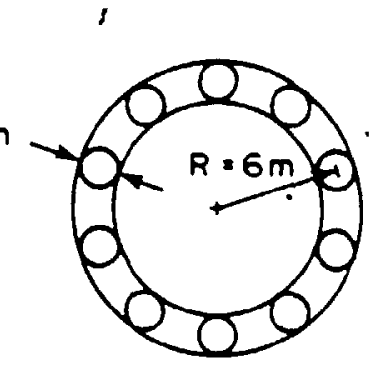

(c) 10 PILES

Figure 5-11: Connguration of the Three Plle Groups Consldered in the Example

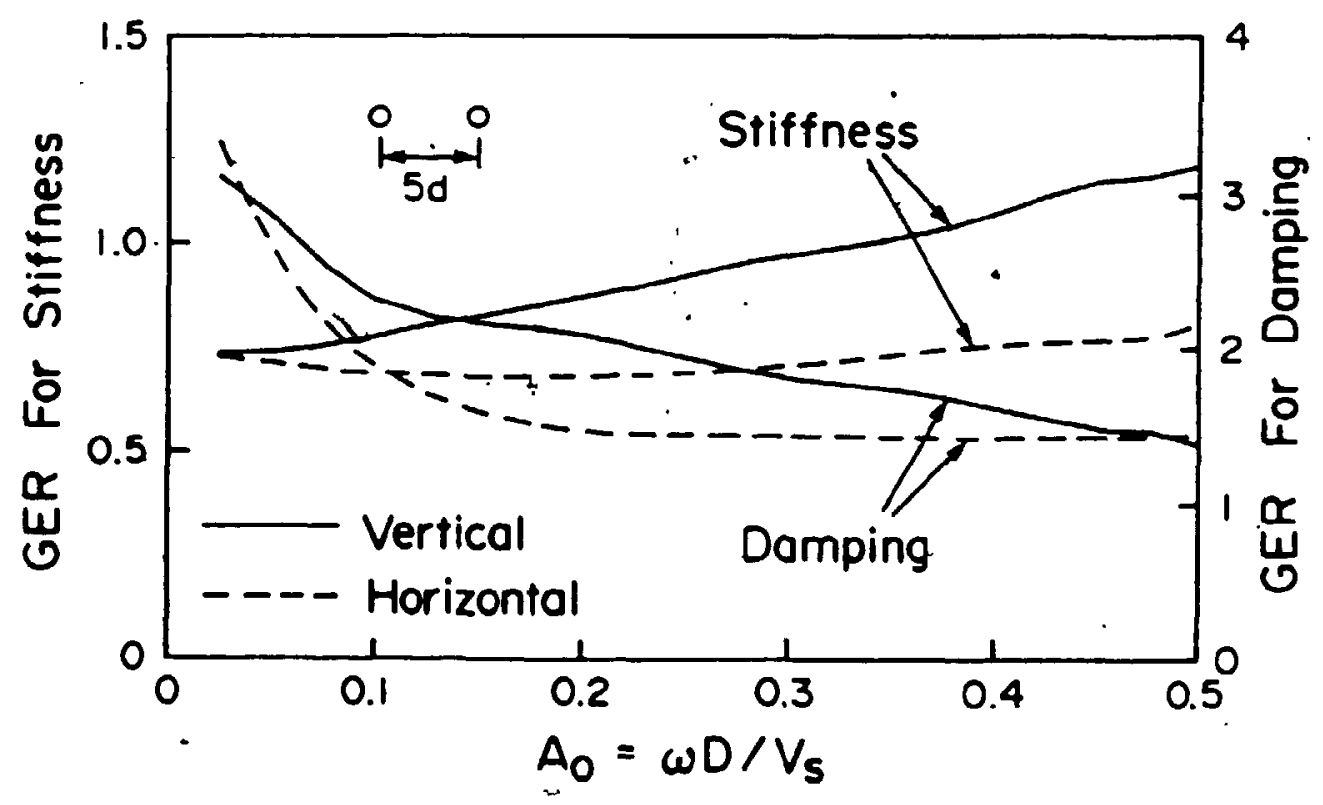

Figure 65-12: Efnclency Ratlo for Stlffness and Damplng for a Group of Two Plles 


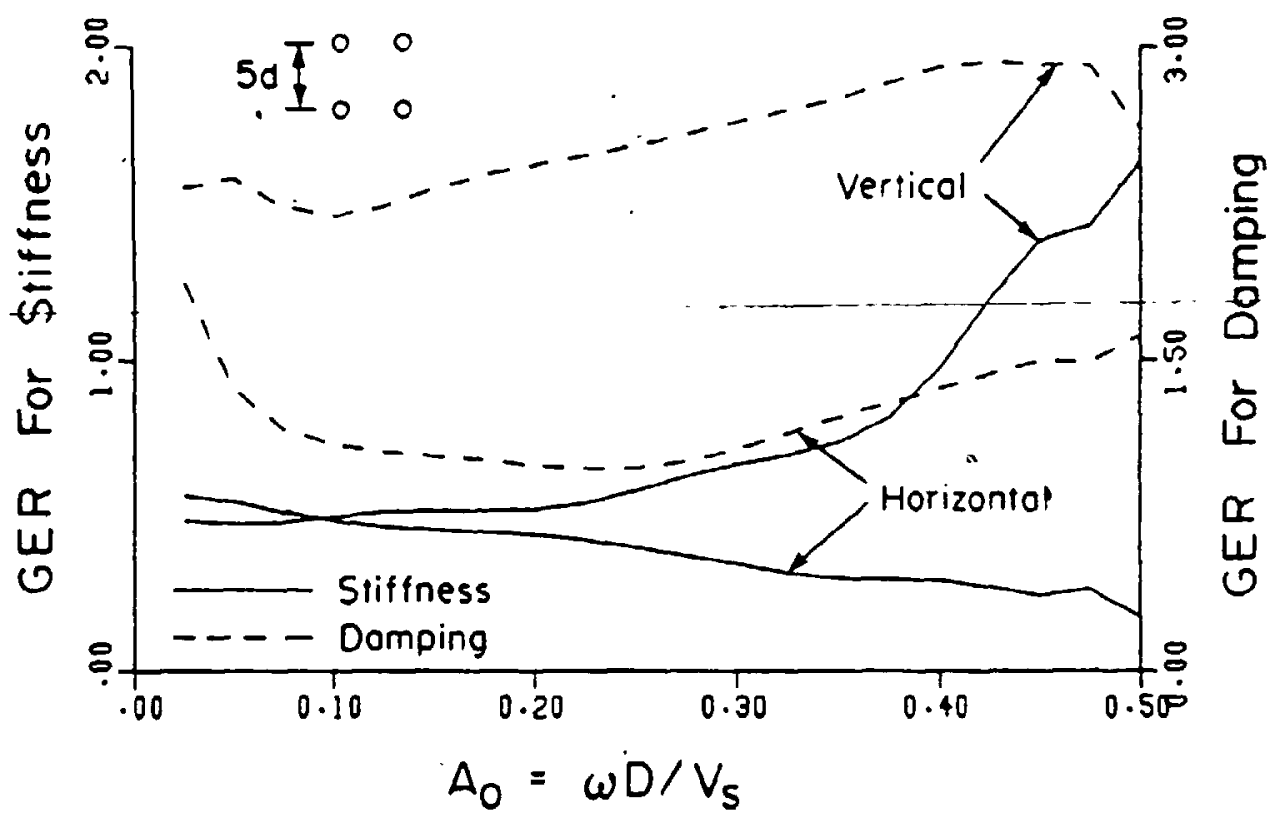

Figure 5-13: Emclency Ratlo for Stinness and Damping for a Group of Four Plles

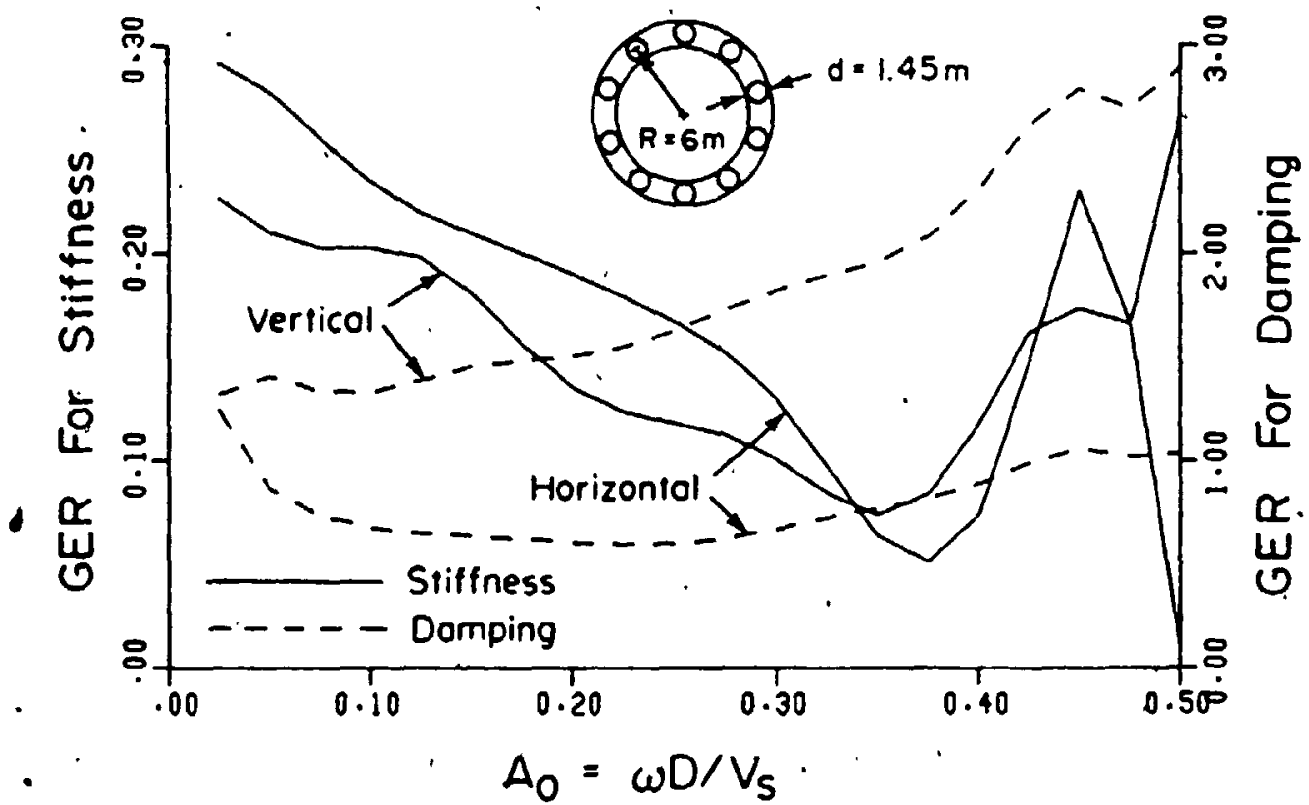

Figure 5-14: Ernclency Ratlo for Stiffness and Damping for a Group of Ten Plles 


\section{Chapter Six Wave Forces on Offshore Structures}

\subsection{Introduction}

Estmation of nuld loading on offshore structures due to waves and currents Is performed in two main steps. First, the water particle kinematics are evaluated and then using a force theory. Wave loads on the specific structure are evaluated.

Early attempts to calculate wave kinematics were based entirely on a regular wave concept. In this approach, the now kinematles is completely specined. for a glven water depth. by the wave helght and perlod. However. real ocean waves are far too Irregular to be adequately described by a single progresslve wave and a cholce is made elther to employ a time varying, complex deterministlc model with many boundary specincations or to introduce statlstlcal propertles Into the model. The later approach is more feaslble and is implemented by treating the sea surface elevation as a random varlable. Wave directlonallty due to elther uind veerlng or superposition of several storm sýstems propagating in different directlons is accounted for by specirying a directlonal spectrum for the sea surface elevation.

Methods of estlmating wave forces on Immersed bodles depend on the slze of the body In the Incident wave direction (taken as the dlameter for cylindrical bodtes) relative to the wave length. For small dlameter to wave length ratlos. Morison's Equation is used to calculate the wave loads. whlle for large ratlos. diffraction effects are important and wave loads have to be calculated using a diffraction theory.

In this chapter. a revlew of wave loading on offshore structures and the 



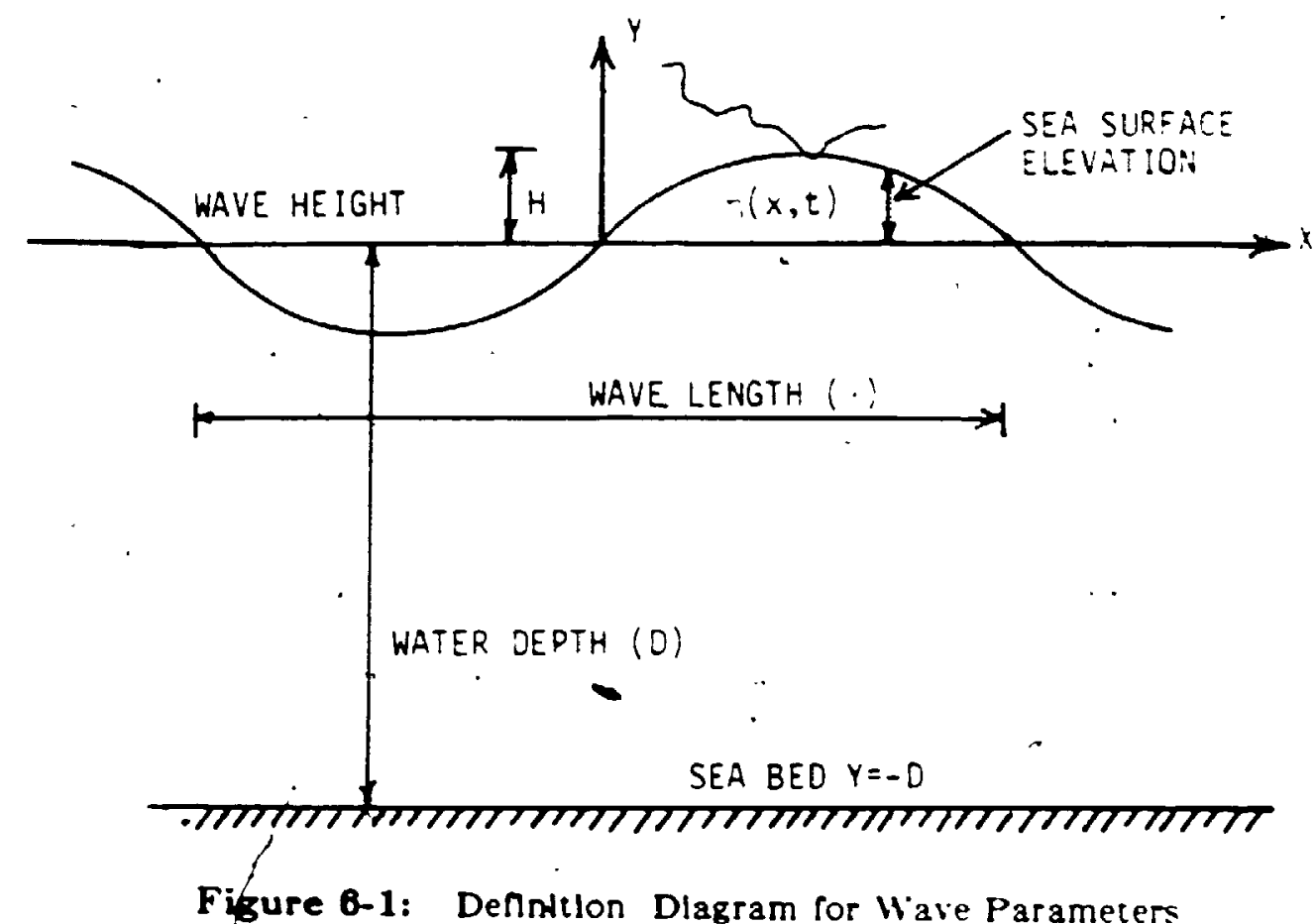

Figure 6-1: Defnntion Dlagram for Wave Parameters

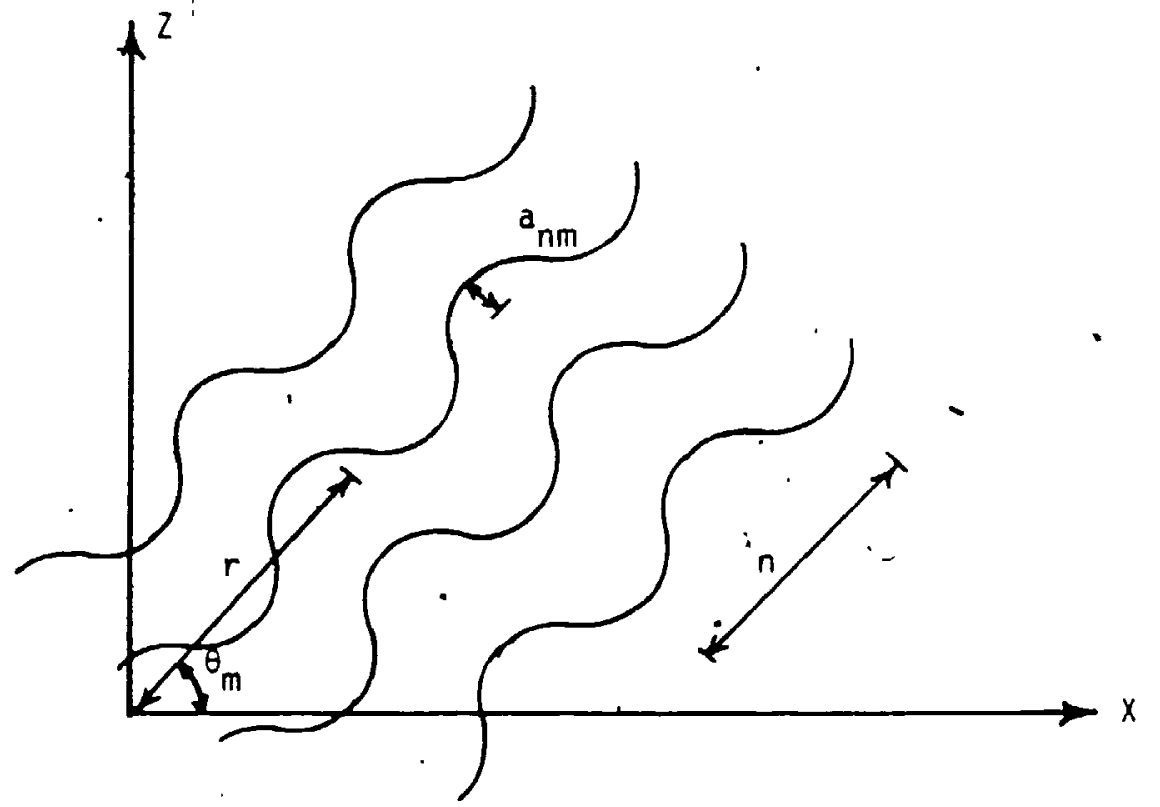

Figure 0-2: Directlonal Wave System 

$\left(v_{R}=\rho i d / \mu\right.$ with $\rho$ and $\mu$ being the nuld density and viscoslty respectively and Keulegan-Carpenter number $\left(\nu_{h}=i_{m} T / d\right.$ where $i_{m}$ Is the mean veloclty-or the nuld and $T$ is the perlod of osclliation). Numerous experiments were conducted to estlmate the values of $C_{11}$ and $C_{D}: 12 i-130 ;$. however, a wide scatter has been reported by most investigators. A survey of publlshed data for the values of $C_{D}$, and $C_{14}$ and thelr ranges of valldity is glven in $i 126_{i}$. At high heuleganCarpenter numbers, drag forces are more importar. and the now is drag dominated whlle at lower values of $\nu_{h}$. Inertla effects are more important and the now is Inertla dominated. The dependency of $C_{l}$, and $C_{h}$, on $x_{h}$, and $x_{R}$ make them vary wilh depth and frequency.

For $d / \lambda>0.2$ the veloclty and acceleration of the now are not constant over a distance equal to the member dlameter and the presence of the cyllnder causes wave scattering aRd, disturbance of the now neld. Diffraction analysis in this case is important were the total force is determined by Integrating the pressure evaluated from fthe) superposition of the undisturbed pressure neld (Froude-kirjlov component) and the pulsating pressure resulting rom the disturbance of the now neld \{126\}.

The drag term in Morison's Equation is nonlinear and has to be linearized if the statistical representation of the random wave forces is to be employed. Borgman $[131\}$ derived a serles representation of the covarlance function of the nonlinear drag term. He showed that the serles converges quite rapldly and that the error Introduced by conslderlne the nist term only. Which is linear. Is quite small [132]. Malhotra and Penzlen [133] used the equivalent llnearlzation technlque to linearize the drag term and obtalned the sage expression whlch results from the nrst term approximation of Borgman.

Short crested. Waves observed in ocean wave systems are modeled using the 
directlonal spectrum of sea. surface elevation. Recent advances in measuring technlques enabled more data to be gathered and analyzed wilh the alm of establishing a rellable modet for the directlonal specirum -234-136:. To of directional spectrum results in the reduction of along wave forces and allows the prediction of lateral forces [137,138;. For structures comprising a fin vertlcal cyllnders. the spectra of wave forces can be obtained by Integratine the wave. loads over the cyllnders [139.' nowever: for structures with severa! member of different orlentations. the member areas and volumes are lumped at thr nodes. $140^{\circ}$.

Vortex exclted oscllations. which are partlcularly important when currents are anticlpated, recelved relatlvely less attention partly because of the difnculty assoclated with developing rellable models to estimate such forces. However. studles deallng with this problem indicate that vortex shedding ocurs at a frequency double the wave frequency and. that under lock-In conditions. substantial dynamic amplincations in both, the transverse and the longltudinal directlons are produced [141].

In the current study, the llnear wave theory is employed to enable the statistical representation of random waves. Wave forces on members of the tower are evalpated using the modined Morlson's Equation whlch accounts for the motion of the cylinder [142]

$$
F=\frac{1}{2} \rho C_{D} d|\dot{v}-\dot{u}|(\dot{v}-\dot{u})+\rho \pi \frac{d^{2}}{4}\left|C_{M} \ddot{v}-\left(C_{M}-1\right) \ddot{u}\right|
$$

where $u$ and $u$ are the acceleration and velocity of the cyllnder, respectlvely. The IInearlzed form of the drag force based on the equivalent llnearlzation tectinlque and employed by many researchers, e.g. $(143-145)$. is used in inls study. For a nexible cyllnder. the llnearlzed drag force is given by

$$
(i-i)|\dot{v}-\dot{u}|=\sqrt{8 / \pi} \sigma_{\dot{r}}(\dot{v}-\dot{u})
$$






\subsubsection{Unidirectional Spectrum (Frequency Spectrum)}

These are specined for elther fully or partlally developed seas. Spectra of the Mrst category are expressed In terms of a reference mean $\mathrm{w} / \mathrm{nd}$ speed at $18.5 \mathrm{~m}$ above the mean sea level. $C$, as the only parameter [153-155;. Spectral forms of the second category account for fetch or fetch and duration!156-158:

- Rerson-Moskourt: Spectrum |155): relates to fully developed seas and is wirltien as

$$
S_{h h^{\prime}}(-)=\frac{\alpha g^{2}}{\dot{s}^{5}} e^{-0: 11 \Sigma^{\prime}-^{\prime}}
$$

where $\alpha=8.1 \times 10^{-3}$ and is termed the Phillips constant, $g$ is the gravilly acceleration and $\bar{a}=g / C$.

- Bretschnezder Spectrum (156) Is glven In terms of the slgnincant wave helght $H$, and the spectral peak frequency $\dot{*}_{0}$ which are in turn obtalned from hindcasting relations in terms of the wind speed $\mathrm{C}$ and fetch and duration of the storm.

- JO.VSWAP Spectrum [157]: provides a modification to the PiersonMoskowitz spectrum to account for the fetch llmited waves and gives a more sharply peaked spectrum.

Other proposed frequency spectra include the slx parameter wave spectrum by Ochl and Hubble [158] which is Intended to represent almost all stages of development of a sea during a storm.

In thls Investigation, the Plerson-ifloskowitz sea surface elevation spectrum. shown in Fig. 6.3. Is used.

\subsubsection{Directional Spectrum}

It is convinlent to express the directlonal spectrum in the form

$$
S_{h h}(\omega, \theta)=S_{h h}(\omega) G(\omega, \theta)
$$

where $G(\omega, \theta)$ is a directional spread function which represents the distribution of wave energy among, waves progressing in different directlons. It satisnes the following relatlonshlp 


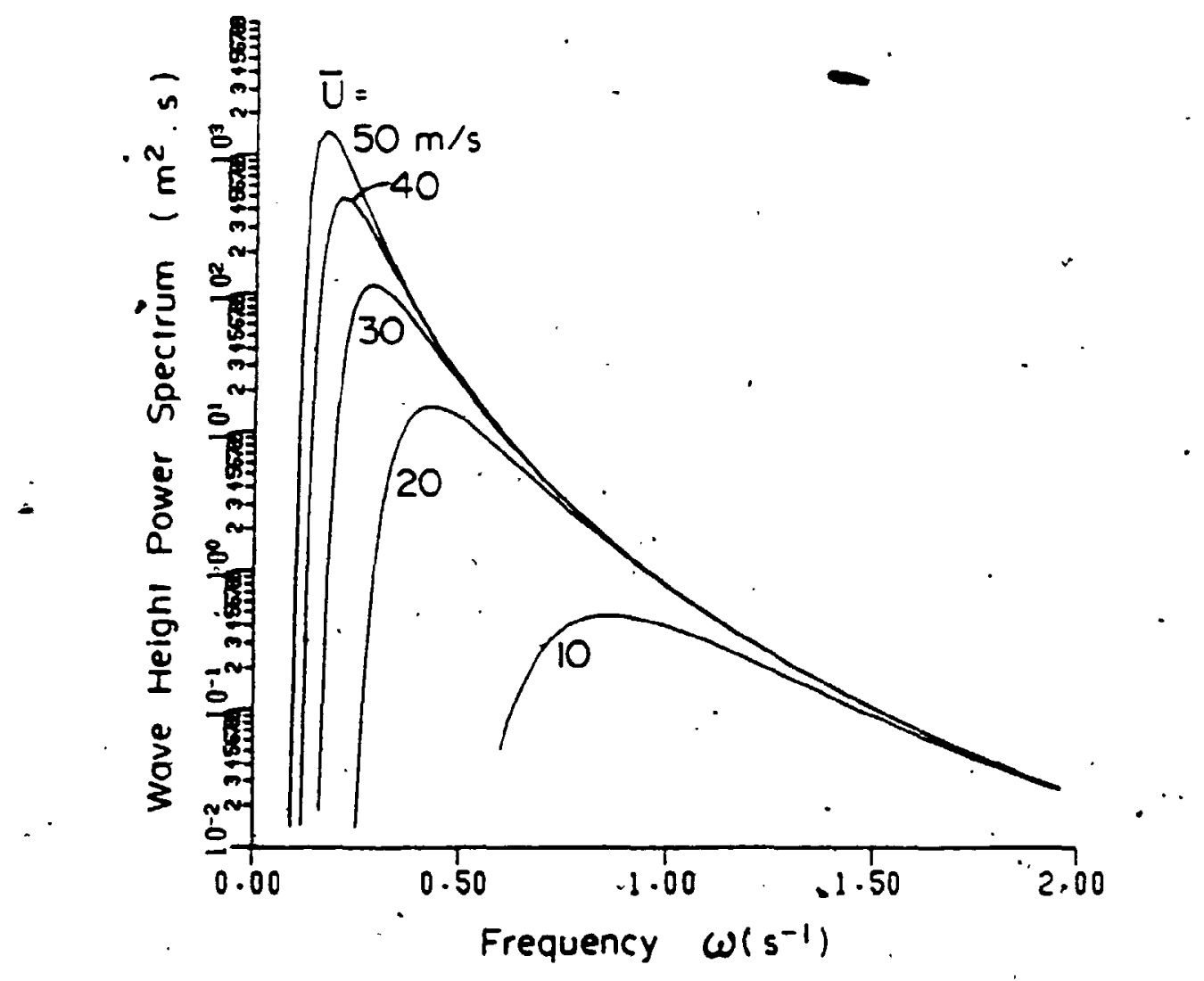

Figure 6-3: Plerson-Moskowliz Spectrum of Sea Surface Elevation<smiles>[Y][14C](=[14CH]C)[14CH2]C</smiles> 

where $W_{n}$ are weighting coemclents to enable the use of a limited number of Fourler coemclents instead of the Innnite serles.

The angular. spread is not constant for all frequencles: it is very narrow around the spectral peak frequencles and widens rapldly towards hlgher and lower. frequencles [134]. The spreading functions mentloned abose could be made frequency dependent by chosing the parameters $S$ or a to be so. A rrequency dependent directlonal spreading function was proposed by Cote et al. ¿162!.

In thls study, the circular normal spread function. Eq. 6.18. Is used. The directional spread parameter $a$ is arbltrárlly made frequency dependent using the relationship

$$
a=\left\{\begin{array}{l}
\bar{a} \mid 1-0.25(\bar{\omega}-\omega) / \bar{\omega} \text { for } 0<\omega<\bar{\omega} \\
\bar{a}\left[1-0.5(\omega-\bar{\omega}) /\left(\omega_{\max }-\bar{\omega}\right)\right] \text { for } \bar{\omega}<\omega<\omega_{\max }
\end{array}\right.
$$

In Eq. 6.20. $\bar{w}$ is the spectral peak frequency. $\omega_{\text {mar }}$ is arbltrarlly set to a high value at the low energy content of the spectrum. For $\dot{C}=20 \mathrm{~m} / \mathrm{sec}, \omega_{\text {maz }}$ is chosen as $5 \mathrm{rad} / \mathrm{sec}$ and $\bar{a}$ is the value of $a$ at $\omega=\bar{\omega}$. The higher the value or $\bar{a}$. the more concentrated the spectrum is around the mean direction of wave advance, $\sigma$. Shown in Fig. 6.4 is the Circular Normal Dyéctlonal Distribution function plotted for different values of $\bar{a}$ and $a t \omega=\bar{w}$.

\subsubsection{Water Particle Kinematics Spectra}

In the following. spectra of water partlcles kInematles are derlved based on the statlonary Gaussian model of random waves discussed in Subsection 0.3.1. Cross spectrum of water partlcle velocltles in the $X$ direction at any 2 polnts in a directlonal wave system is derlved in detall. A general expression that can be adapted to the cross spectra of other veloclty components is then glven. Cross 


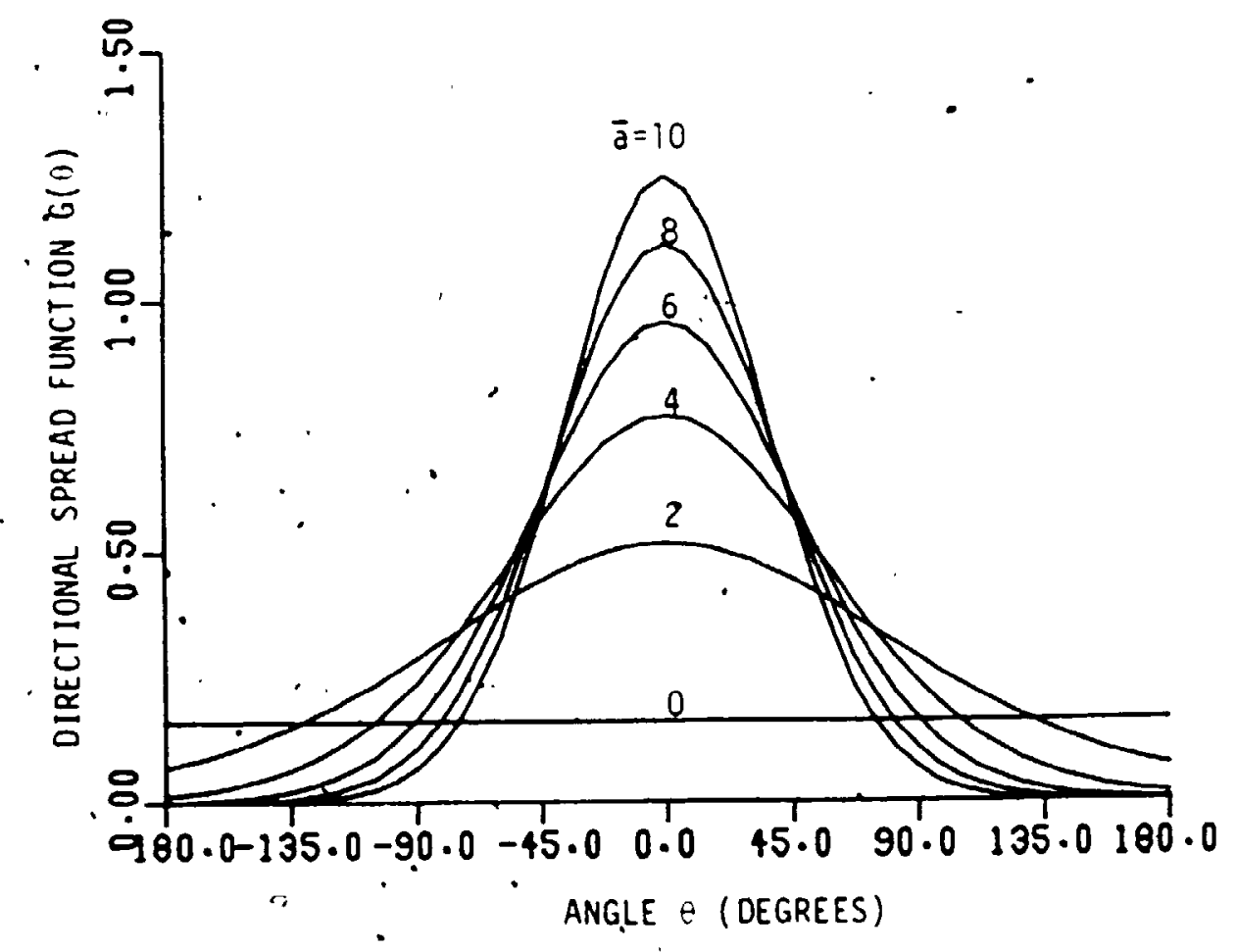

Figure 6-4: Clrcular Nórmal.Dlrectlonal Spread Functlon 
spectra for a unldirectional wave system can be simllarly derlied and only the nnal expression Is glven.

An alternative representation of the water particle kinemattes based on the use of a coherence function is then introduced. This alternative anproach. which Is termed the conerence function model. Is employed in Section 6.6 to evaluate wave forces on cyllndrical mèmbers of ofrshore towers.

\subsubsection{Directional Spectrum Model}

The contribution sea surface elevation from waves advancing in direction $\theta_{m}$ with frequency $\dot{\alpha}_{n}$ and amplltude $a_{n m}$. Flg. 6.2. Is glven by

$$
h_{n m}=a_{n m} \cos \left(\kappa_{n} r-\dot{H}_{n} t+c_{n m}\right)
$$

where $r$ is measured in reference to a nxed origin in the direction of wave adrance. The mean square value of the sea surface elevation $h_{n m}$ during one cycle Is

$$
\sigma_{h_{n m}}^{2}=\frac{a_{n m}^{2}}{2}=S_{h h}\left(\alpha_{n}, \theta_{m}\right) \Delta \nu \Delta \theta
$$

therefore $a_{n m}$ is

$$
a_{n m}=\sqrt{2 S_{h h}\left(\omega_{n} \cdot \theta_{m}\right) \Delta \omega \Delta \theta}
$$

The polar coordinate $r$ is expressed in terms of carteslan coordlnates as

$$
r=x \cos \theta_{m}+z \sin \theta_{m}
$$

From Alry wave theory, the contribution to the horlzontal veloclty at depth $y$ from such waves is

$$
\dot{v}_{n m}=\omega_{n} \frac{\cosh \kappa_{n}(y+D)}{\sinh \kappa_{n} D} h_{n m}
$$

and the horlzontal veloclty component in directlon $x$ is written as

$$
i_{n m(r)}=\dot{v}_{n m} \cos \theta_{m}
$$

From Eqs. 6.21 and 6.23 to 6.25, Eq. 6.26 is written as

$$
\begin{aligned}
i_{n m(s)}= & \omega_{n} \frac{\cosh \kappa_{n}(y+D)}{\sinh \kappa_{n} D} \sqrt{2 S_{h h}\left(\omega_{n} \cdot \theta_{m}\right) \Delta \omega \Delta \theta} . \\
& \cdot \cos \left(\kappa_{n}\left(x \cos \theta_{m}+2 \sin \theta_{m}\right)-\omega_{n} t+c_{n m}\right) \cos \theta_{m}
\end{aligned}
$$


and the total horlzontal veloclty assoclated with waves progressing with $N$ dirferent frequencles and from 11 different directions, at each discrete frequency. is glven by

$$
\begin{aligned}
i_{z}(t)= & \sum_{n=1}^{N} \sum_{m=1}^{M} \omega_{n} \frac{\cosh \kappa_{n}(y+D)}{\sinh \kappa_{n} D} \sqrt{2 S_{h h}\left(\omega_{n} \cdot \theta_{m}\right) \Delta_{m} \Delta \theta} \\
& \cdot \cos \left[\kappa_{n}\left(x \cos \theta_{m}+z \sin \theta_{m}\right)-\alpha_{n} t+c_{n n_{i}} \cos \theta_{m}\right.
\end{aligned}
$$

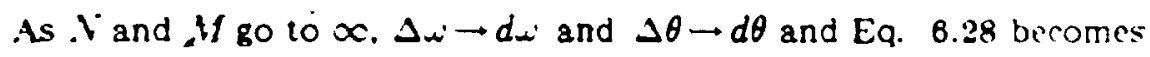

$$
\begin{aligned}
& -i_{r}(t)=\int_{0}^{\infty} \int_{0}^{2 \pi} u^{2} \frac{\cosh \kappa(y+D)}{\sinh \kappa D} \sqrt{2 S_{h h}(x ; \theta) d i d \theta} \\
& . \cos [\kappa(x \cos \theta+z \sin \theta)-\alpha t+\epsilon \cos \theta
\end{aligned}
$$

To obtain the cross spectrum of water particle veloctules at any 2 polnts. thelr cross correlation funcilon is nrst evaluated and then Fourler transformed. The cross correlation function of horizontal velocltes in the $\mathrm{X}$ direction at any 2 polnts in the now neld is written as

$$
R_{v_{x 1}{ }^{\prime}{ }_{22}}(\tau)=\left\langle\dot{v}_{x 1}(t) \dot{v}_{x 2}(t+\tau)\right\rangle
$$

where $<>$ Indiçates the mean value and $t$ ls the llme lag for whlch the cross correlation function is evaluated. 1.e.

$$
\begin{aligned}
R_{i_{x 1}{ }^{2} x 2}(\tau)= & \int_{0}^{\infty} \int_{0}^{2 \pi} \omega^{2} \frac{\cosh \kappa(y 1+D) \cosh \kappa(y 2+D)}{\sinh ^{2} \kappa D} \\
& \left..2 S_{h h}(\omega \cdot \theta)<\cos \mid \kappa(x 1 \cos \theta+z 1 \sin \theta)-\omega t+\epsilon\right] \\
& . \cos |\kappa(x 2 \cos \theta+z 2 \sin \theta)-\omega t-\omega \tau+\epsilon|>\cos ^{2} \theta d \theta d \omega
\end{aligned}
$$

where $x 1, y 1, z 1$ and $x 2, y 2$ and $z 2$ are the cartestan coordlnates of points $z$ and 2. respectlvely. Using trigonometrlc Identltles, and after some manipulations, it can be shown that

$$
\begin{aligned}
& <\cos |\kappa(x 1 \cos \theta+z \sin \theta)-\omega t+\epsilon| \\
& \cos (\kappa(x 2 \cos \theta+z 2 \sin \theta)-\omega t-\omega \tau+\epsilon)>= \\
& \left.\frac{1}{2} \cos \mid \kappa(x 1-x 2) \cos \theta+\kappa(z 1-z 2) \sin \theta+\omega \tau\right)
\end{aligned}
$$

In Eq. 6.31, $S_{h h}(\omega, \theta)$ is the one slged spectrum (extending from 0 to $x$ ) and is related to the two sided spectrum $\mathbf{S}_{h h}(x, \theta)$ by 



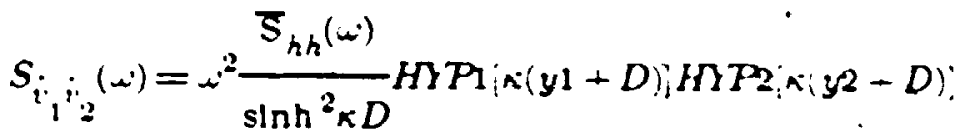

$$
\begin{aligned}
& \int_{-\pi}^{\pi} G(\omega, \theta) C 1(\theta) C 2(\theta) \\
& e^{2 \times(21-r 2) \cos \theta+(z 1-2=2 \ln \theta} d \theta
\end{aligned}
$$

where

$$
C 1(\theta)=\begin{array}{ll}
\cos \theta & \text { for } 1 / / 1 \\
\sin \theta & \text { for } 1 / / Z \\
1 & \text { for } 1 / / \gamma
\end{array}
$$

In which $1 / / X$ indlcates veloclty component at polnt it to be in the $X^{-}$direction. with simllar dennitlons for $1 / / Y$ and $1 / / Z$. $C 2(\theta)$ is simllarly denned for velocity component at point 2. Finally,

and

$$
H \gamma \operatorname{P} \mid \kappa(y)+D)\}= \begin{cases}\cosh [\kappa(y)+D)] & \text { for } 1 / / x \text { or } 1 / ; \\ -2 \sinh [\kappa(y)+D) ; & \text { for } 1 / / \gamma\end{cases}
$$

$$
H_{2} P_{2} \kappa(y 2+D) \mid \doteq \begin{cases}\cosh [\kappa(y 2+D)\}^{\prime} & \text { for } 2 / / x \text { or } 2 / / Z \\ 2 \sinh \mid \kappa(y 2+D) ; & \text { for } 2 / / \gamma^{\circ}\end{cases}
$$

Cross spectral densltes of water partlcle acceleratlons can be obtained from those of the velocitles, l.e.

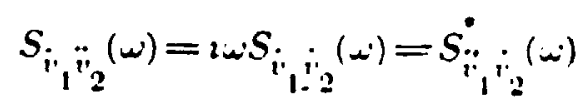

and

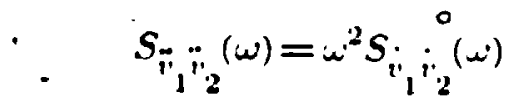

Iniwhlch the asterlsk means the complex conjugate. The general expression in Eq. 6.40 is the samē as that derlved'by Berge[161].

Cross spectra of water partlcle kinematles of unidlrectlonal wave systems can be derlved simllarly and the formulae are glven $\mid a\{133\}$ and $\{151\}$. The general expresslon for cross spectra of water particle velocltles of a unidirectional fully - correlated wave system progressing in a mean direction that makes an angle $\mathbb{\sigma}$ with the $X$ axis is

$$
\because
$$




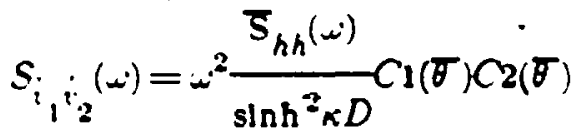

$$
\begin{aligned}
& \left.. H Y P_{1} \mid \kappa(y 1+D)\right] H \Pi P_{2}[\kappa(y 2+D) \text {. } \\
& . e^{2 \times 1}(21-22 \cos \bar{\theta}-1: 1-22 \sin \bar{\theta}
\end{aligned}
$$

where $C l(\bar{\theta})$ and $C 2(\bar{\theta})$ are given by Eq. 6.41. If $\theta$ ls substliuted by $\bar{\theta}$. and $H Y P_{1} \kappa(y 1+D) ;$ and $H P_{2} ; \kappa(y 2+D) ;$ are glven by" Eqs. 6.42 and 6.43 . respectively.

\subsubsection{Coherence Function Model}

In the preceding distusston, a confused sea with short crested waves was modeled as a three dimensional stationary. Gausslan random process. One of the maln features. of this model is that the totad in-Hne (along wave) force on any member of the tower is less than that of a unidirectlonal wave system having the same total energy as pari of thls total energy produces lateral forces. Another reason for the reduction in the along wave forces is that the wave forces are not In phase glong the entire length of the member. This second factor is termed the lack of spatlal correlation and has been brieny discussed by Malhotra and Penzlen [133) who introduced the spatlal cross correlation factor. However, the spatlal - cross correlation factor of Maltiotra and Penzlen was derived for a tributary area and not for line members.

The cross spectra of water particle velocity of the unldirectional fully correlated model, employed by several Investigators is expfessed by Eq. 6.45. For example, in the $\mathrm{X}$ direction, Eq. 6.43 takes on the form

$$
\begin{aligned}
& S_{i_{x 1} i_{z 2}}(\omega)=\omega^{2} \frac{\cosh \kappa(y 1+D) \cosh \kappa(y 2+D)}{\sinh ^{2} \kappa D} S_{h h}\left(\omega^{\prime}\right) \\
& \because e^{2 \times(2) i-32) \cos \theta-(z 1-z 2) \sin \theta} \cos ^{2} \theta \text {. }
\end{aligned}
$$

As can be seen from Eq. 6.47 , the cross spearua of water particle velority at tho 
polnts separated by a distance $J$ varles harmonlcally with a constant amplltude. l.e. With no attenuation. This sltuation is unrealistle singe for short crested waves, the ampllude of the cross spectrum of wave forces attenuates with increased separation. To account for thls factor in the present study. lack of spatial correlation is accounted for through a coherence function and the cross speetrum of water particle veloclty is glven by

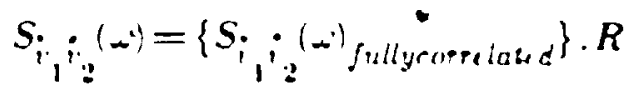

where $R$ is the square root of the coherence function. Several empirical expressions can be used for the coherence function. In thls sudy, the form analogous to that used for atmospherle turbulence lo applierd, l.e.

$$
R=e^{-r \frac{\Delta-}{\lambda}}
$$

where $c$ is an exponentlal decay factor. $J r$ is the absolute value of the distance between the 2 polnts and $\lambda$ is the wave length. The exponentlal decay factor $c$ is to be determined frum laboratory experiments or. peeferably. from full scale measurements.

Physically, a wave system whose cross spectrum of water particle velocity is defned by Eq. 6.48 comprises an Infnnlte number of waves each having a different frequency and a random phase angle. All the propertles of the unidirectional model are retalned except that each wave front is not fully correlated along a line perperidicular to the direction of wave adiance.

\subsection{Wave Forces on Members of Offshore Towers}

With the cross spectral densities of water particle velocitins and accelerations defnned. the spectra of wave forçes on a typlcal Jolnt of an offohore touer can be formulated.

Consider an offshore tower ldeallzed as a spare rame whose cordfliate systerm, is shown in Flg. 6.5, whepe $X$. Y and. $Z$ are the global axwe and $r$, $y$ and $=$ $\div$ 
137

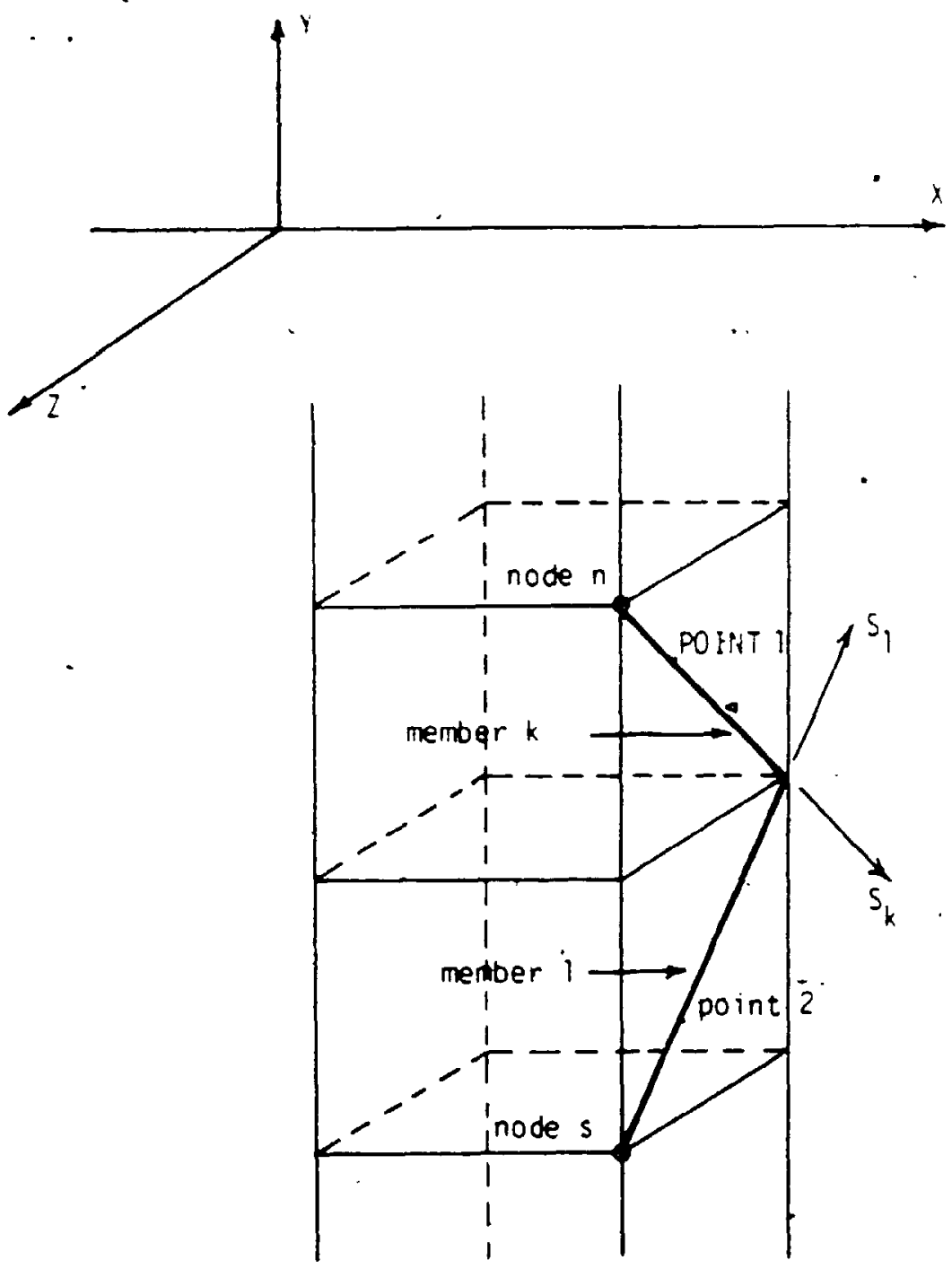

Figure 6-6: Coordinate System for Offshore Tower 
are the global coordinates. Arter statle condensation. each folni has 3 iranslational d.o.f. Let d.o.f. I be poslitoned at node $n$ at which $x_{\text {" mimbers }}$ meet. Also let $p_{k} \cdot q_{k}$ and $r_{k}$ be the direction cosines of the $k^{\text {th }}$ member. Which is attached to Joint $n$, wilh axes $\lambda, \dot{i}$ and $z$, respectwely, and $S_{k}$ be lis element coordinate such that

$$
\begin{aligned}
& p_{k}=\frac{x-I_{n}}{S_{k}} \\
& q_{k}=\frac{y-y_{n}}{S_{k}} \\
& r_{k}=\frac{z-z_{n}}{S_{k}}
\end{aligned}
$$

where $I_{n}, y_{n}$ and $z_{n}$ are the global coordlnates of node $n$. Notlce that $S_{k}$ is alway's positlve and lts value for any polnt on the member represents the distance between that polnt and the Jolnt. Using the modined Morison's Equation. Eq. 6.4. the wave force $W_{i}(t)$ acting on the structure, corresponding to d.o.f. I Is

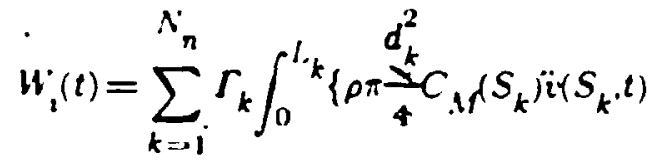

$$
\begin{aligned}
& -\rho \pi \frac{d_{k}^{2}}{4} \mid C_{\lambda}\left(S_{k}\right)-1 ; \ddot{u}\left(S_{k} \cdot l\right) \\
& \left.+\frac{1}{2}-\rho d_{k} C_{l}\left(S_{k}\right) \dot{i} i\left(S_{k}, l\right)-\dot{u}\left(S_{k}, t\right) \| \dot{u}\left(S_{k}, t\right)-\dot{u}\left(S_{k}, t\right)\right\} d d S_{k}
\end{aligned}
$$

where $d_{k}$ and $L_{k}$ are the diameter and trlbutary length of member $k$. respectively. Finally.

$$
\begin{aligned}
& F_{k}= \frac{\sqrt{q_{k}^{2}+r_{k}^{2}}}{} \text { for } 1 / / X \\
& \frac{\sqrt{p_{k}^{2}+r_{k}^{2}}}{\sqrt{p_{k}^{2}+q_{k}^{2}}} \text { for } 2 / / Y \\
& \text { for } 2 / / Z
\end{aligned}
$$

Since d.o.f. I may be In the $X, Y$ or $Z$ direction $, i, \ddot{u}, i$ and $\ddot{i}$ are understood to be the veloclty and acceleration components in the same direction as d.o.f. 2. 
Eq. 6.51 is the general form for wave forces on a typical jolnt and can be greatly simplined if $C_{1}$ and $C_{11}$ are assumed to be constant. To faclliate the evaluation of wave forces, $i$ and $\ddot{u}$ are taken to be constant along the tributary length and equal to thelr values at the nodes. $\dot{u}_{i}$ and $\ddot{u}_{i}$, respectively. For a very long element. additional nodes on the element may be introdured to justify the assumption. For the purpose of evaluating the hydrodyamis damplng the water particle veloclty in the third term is taken as constant with the above assumptions. Eq. 8.51 simplines to

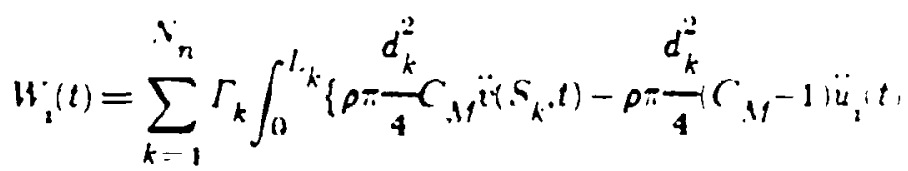

$$
\begin{aligned}
& \left.+\frac{1}{2} \rho d_{k} C_{D} \mid \dot{v}_{1}(t)-\dot{u}_{i}(t)_{1}\left(i_{i}(t)-\dot{u}_{i}(t)\right)\right\} d . S_{k}
\end{aligned}
$$

The drag term Is llnearlzed using Eq. 6.5 and Eq. 6.53 becomes

$$
\begin{aligned}
W_{i}(t)= & \sum_{k=1}^{x_{n}} \Gamma_{k} l \int_{0}^{l_{k}}\left\{\rho \pi \frac{d_{k}^{2}}{4} C_{k} \ddot{i}^{2}\left(S_{k}, t\right)\right. \\
& \left.+\frac{1}{2} \rho d_{k} C_{D} \sqrt{8 / \pi} \sigma_{r_{i}} i\left(S_{k}, t\right)\right\} d S_{k} \\
& -\rho \pi \frac{d_{k}^{2}}{4}\left(C_{M}-1\right) L_{k} \ddot{u}_{i}(t) \\
& \left.-\frac{1}{2} \rho d_{k} C_{D} \sqrt{8 / \pi} \sigma_{r_{1}} L_{k} \dot{u}_{i}(t)\right\}
\end{aligned}
$$

where $\sigma_{r_{1}}$ ls the standard devlation of the relative velocky. assoclated with d.o.f. 1 , between the water partlcle and the structure. The thlrd and fourth terms are the added mass and hydrodynamlc damplng. respectlvely, and to be transfered to the other side of the equation of motion. Hence, the effectlve force assoclated with d.o.f. i. $P_{1}(t)$. is

$$
P_{i}(t)=\sum_{k=1}^{N_{n}} \Gamma_{k} \int_{0}^{l}{ }^{l}\left\{\alpha_{k} \ddot{i}\left(S_{k}, l\right)+\beta_{k} \sigma_{r_{i}} i\left(S_{k}, t\right)\right\} d S_{k}
$$


- $\quad \alpha_{k}=\rho \pi \frac{d_{k}^{2}}{4} C_{M}$

and

$$
3_{k}=\frac{1}{2} \rho_{h}\left({ }_{1}, \sqrt{8 / \pi}\right.
$$

The cross spectrum of the nodal loads assoclated with d.o.f 1 and $m$.

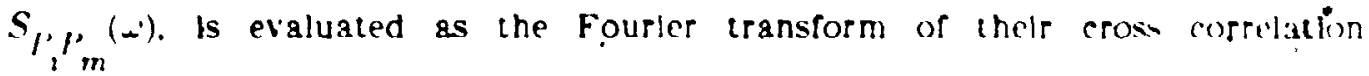
function. This process ylelds

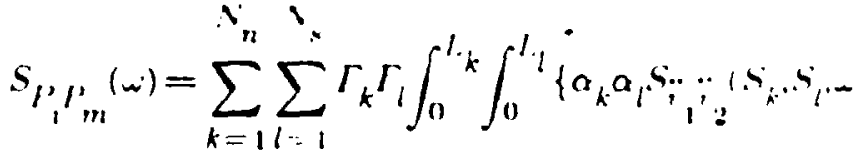

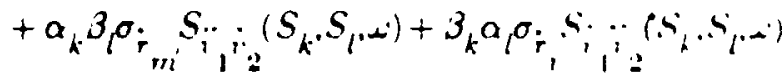

$$
\begin{aligned}
& \left.+3_{k} 3_{\gamma} \sigma_{r_{1}} \sigma_{i} S_{i_{i} ;}\left(S_{k} . S_{l} \cdot \omega\right)\right\} d S_{l} d S_{k}
\end{aligned}
$$

where the subscripts 1 and 2 refer to any $\imath$ wo points falling on members $k$ and $l$. respectlvely. $L_{l}$ and $S_{l}$ are the trlbutary length and element coordinate. respectlvely, of the $l^{\text {th }}$ member attached to jolnt $s$, at whlch $V^{*}$ members meet. $I_{i}$ is given by

$$
\begin{aligned}
& \Gamma_{l}=v^{\prime} q_{1}^{2}+r_{l}^{2} \quad \text { for } m / / X^{-} \\
& \sqrt{p_{1}^{2}+r_{1}^{2}} \quad \text { for } \mathrm{m} / / \mathrm{l} \\
& \sqrt{p_{l}^{2}+q_{i}^{2}} \quad \text { for } m / / Z
\end{aligned}
$$

where $p_{l}, q_{l}$ and $r_{l}$ are the directlon cosines of member $l$ with axes $x, r$ and $Z$. respectively, and are glven by

$$
\begin{aligned}
& p_{l}=\left(x-x_{s}\right) / S_{l} \\
& q_{l}=\left(y-y_{s}\right) / S_{l} \\
& r_{l}=\left(z-z_{s}\right) / S_{l}
\end{aligned}
$$

On substltuting by Eqs. 6.44 and 6.45. Eq. 6.58 ylelds 


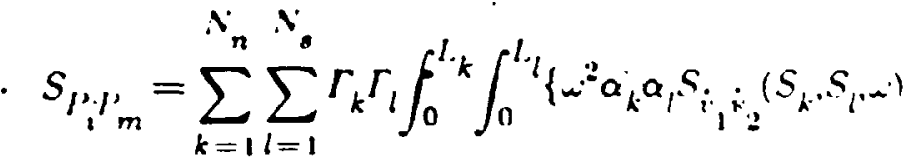

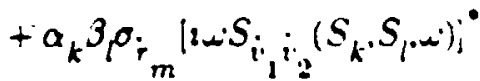

$$
\begin{aligned}
& +2 \omega \cdot 3_{k} \alpha \sigma_{r_{2}} S_{i, i_{i}}\left(S_{k}, S_{l, \mu}\right) \\
& \left.+\beta_{k} \beta_{i} \sigma_{r_{3}} \sigma_{r_{m}} S_{\dot{r}_{1} \dot{*}_{2}}\left(S_{k}, S_{l}, \omega\right)\right\} d S_{l} d S_{k}
\end{aligned}
$$

Arter rearranging the terms in Eq. 6.61. the cross spectrum of nodal loads can be wrltten as

where

$$
S_{Y^{\prime} \prime_{m}^{\prime}}=\sum_{k=1}^{N_{n}} \sum_{l=1}^{\lambda_{k}} \Gamma_{k} \Gamma_{l}\left\{G_{k l}\left(\omega^{\prime}\right) I_{k l}+\alpha_{k} 3_{l} \rho_{r_{m}}\left[2 I_{k i} i^{\bullet}\right\}\right.
$$

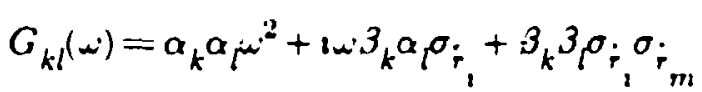

and

$$
I_{k l}=\int_{0}^{l} \int_{0}^{l^{\prime} l} \int_{0} S_{i_{1} i_{2}}\left(S_{k} \cdot S_{l} \cdot \dot{\cdot}\right) d S_{l} d S_{k}
$$

The standard devlations of the relative veloclties, $\sigma_{r}$ and $\sigma_{r}$ can not be obtalned untll the response is evaluated, hence they are evaluated in an lteratte procedure. In the nrst lteration. the structural velocltles are assumed to be $20 r o$,

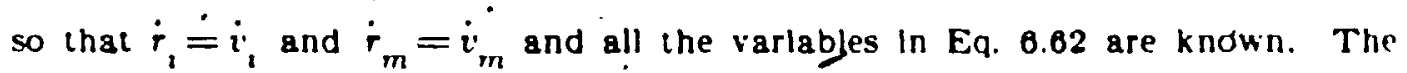
cross spectra of nodal loads, for glven values of $\alpha-s$ and $3-s$ thus depend on the Integrals of the cross spectra of water partlcle velocltles along the members. $I_{k l}$.

\subsection{Directional Spectrum Model}

\subsubsection{Formulation of Wave Forces}

In this model, the spectra of water particle. velocitles are obiained from the general expression of Eq. 6.40. To evaluate the Integrals $I_{k l}$ In Fq. 6.64. the

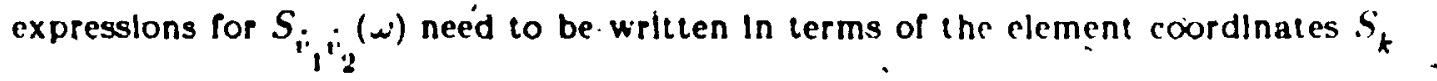
and $S_{l}$. The coordlnates $x 1, y 1,21$ and $22, y 2,22$ are related to $S_{k}$ and $S_{1}$ by 


$$
\begin{array}{ll}
x 1=x_{n}+p_{k} S_{k} & x 2=x_{*}+p_{l} S_{l} \\
y 1=y_{n}+q_{k} S_{k} & y 2=y_{k}+q_{l} S_{l} \\
z 1=z_{n}+r_{k} S_{k} & z 2=z_{k}+r_{l} S_{l}
\end{array}
$$

In thls section, the expression for $I_{k l}$ Is given only for the case when both veloclty components are in the $X$ direction and is termed $I_{k} l_{j}$, l.e.

$$
I_{k^{\prime} l_{x}}=I_{k l} \text { for } i / / X \text { and } m / / X
$$

The expresslons for all other cases are glyen In Appendlx B. On substitution by: Eqs. 6.85 and 6.40 . Eq. 6.64 ylelds

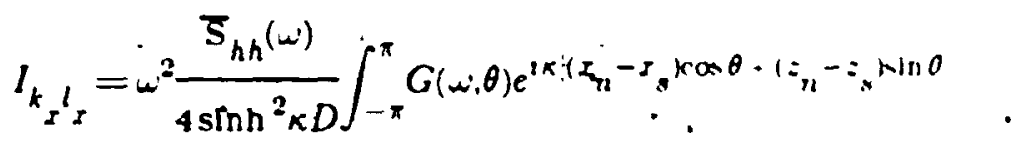

$$
\begin{aligned}
& \cdot\left\{\int _ { 0 } ^ { l } { } _ { k } \left(e^{A_{n}}-\kappa \cdot s_{k}\left(q_{k}+1 p_{k} \cos \theta+i r_{k} \sin \theta\right)\right.\right. \\
& \left.\left.+e^{-.1_{n}+x \cdot S_{k}\left(-q_{k}+i p_{k} \operatorname{ros} \theta+i r_{k} \operatorname{tn} \theta\right)}\right) d S_{k}\right\}
\end{aligned}
$$

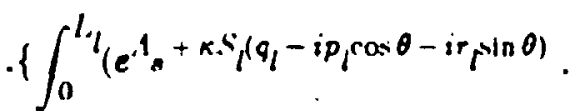

$$
\begin{aligned}
& \left.\left.+e^{-. I_{s}+\kappa . S_{l}\left(-q_{l}-2 p \cos \theta-v l_{l} \ln \theta\right)}\right) d S_{l}\right\} \cos ^{2} \theta d \theta
\end{aligned}
$$

where

$$
A_{n}=\kappa\left(y_{n}+D\right)
$$

and

$$
A_{n}=\kappa\left(y_{n}+D\right)
$$

Denote

$$
\begin{aligned}
& \varsigma=\omega^{2} \frac{\bar{S}_{h h}(\omega)}{\sinh ^{2} \kappa D} \\
& R_{a k}=\left|q_{k}+2\left(p_{k} \cos \theta+r_{k} \sin \theta\right)\right| \\
& R_{b k}=\left\{-q_{k}+i\left(p_{k} \cos \theta+r_{k} \sin \theta\right) \mid\right. \\
& R_{a l}=\left[q_{l}-r\left(p_{l} \cos \theta+r_{l} \sin \theta\right)\right] \\
& R_{b l}=\left|-q_{l}-i\left(p_{l} \cos \theta+r_{l} \sin \theta\right)\right|
\end{aligned}
$$

On sarrying out the Integrations with respect to $S_{k}$ and $S_{l}$. Eq. 6.07 becomes 


$$
\begin{aligned}
& I_{k_{z} l_{z}}=\frac{\varsigma}{4 x^{2}} \int_{-\pi}^{\pi} G(\nu, \theta) \cos ^{2} \theta .1_{n ;} \\
& \cdot i \frac{1}{R_{a k}} e^{\cdot 1} n\left(e^{R_{a k} \bar{\kappa}}-1\right)+\frac{1}{R_{b k}} e^{\left.-. R_{n\left(e^{k} k_{b k} \bar{k}\right.}-1\right) !}
\end{aligned}
$$

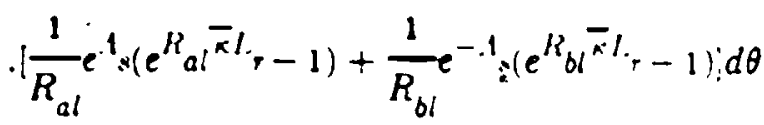

where

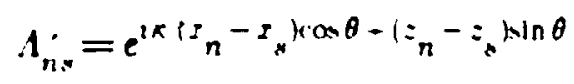

The dimensionless' wave number $\bar{\kappa}$ is defned as

$$
\bar{\kappa}=\kappa L_{k}=2 \pi\left(L_{k} / \lambda\right)
$$

and

$$
L_{r}=L_{l} / L_{k}
$$

A more general expression for the integrals $I_{k l}$ in all other directlons is glven in Appendix B.

\subsubsection{Parametric Study}

A typlcal cross spectrum of wave forces on two members $k$ and $l$ as glven by Eqs. 6.62 and 6.72 depends on $C_{D}$ and $G_{M}$ as well as two groups of parameters:

1. Geometric Parameters and Wind Speed: $\left(y_{n}+D\right) / L_{k}$. $\left(y_{s}+D\right) / L_{k^{\prime}}\left(x_{n}-I_{s}\right) / L_{k^{\cdot}}\left(z_{n}-z_{s}\right) / L_{k}, D / L_{k}, L_{r}$ direction cosines of both members, the tributary length $L_{k} d_{k}$ and $d_{l}$ and the mean $k$ ind speed $\mathrm{C}$.

2. Wave System Parameters: dimenslonless wave number $\bar{\kappa}$, directlonal . sp̀read parameter $\bar{a}$ and mean direction of wave advance $\bar{\nabla}$.

The more Important parameters are those of the second group and a parametrle study is conducted to lllustrate the varlation of the spectra of wave forces with these parameters for a given set of values for the parameters of the nrst group. 
Spectra of wave forces evaluated using the directlonal spectrum differ from those evaluated using a unidirectional spectrum in two main aspects:

1. The lateral component of wave force spectrum (normal to the mean directlon of wave advance) is present in the case of a directlonal spectrum.

2. The resultant wave force spectrum on a member is reduced when using a directlonal spectrum.

These two factors are closely examined together with the approximation Involved by considering a constant value-of the water particle veloclty, which is : Its value at the node, rather than a varying one along the member. For the parametric study, only one member is assumed to be connected at each of the 2 Jolnts, l.e. $\Lambda_{n}=N_{n}=1$. The following values are used for the parameters of the nrst group, unless otherwlse stated:

$$
\begin{aligned}
& \left(y_{n}+D\right) / L_{k}=\left(y_{s}+D\right) / L_{k}=8 . \quad\left(x_{n}-I_{s}\right) / L_{k}=\left(z_{n}-z_{s}\right) / L_{k}=0 . \\
& D / L_{k}=10 ., \quad \mathrm{C}=20 \mathrm{~m} / \mathrm{sec} \quad L_{r}=1, L_{k}=10 \mathrm{~m}, \quad d_{k}=d_{l}=1 \mathrm{~m} \\
& \text { and } p_{k}=p_{l}=q_{k}=q_{l}=0 . C_{D} \text { and } C_{M} \text { take on the values of } \\
& 2 \text { and 1.4. respectlvely. }
\end{aligned}
$$

The orlentation of the two members In each case is shown on the plot presenting the resuits of this cage. The spectral peak dimenslonless wave number corresponding to a charaterlstlc wind speed of $20 \mathrm{~m} / \mathrm{s}$ is $\bar{\kappa}=0.245$.

\subsubsection{Variation in The Lateral Forces With the Wave Syatem}

\section{Parametera}

The ratto between the spectra of the hoklzombal force components in directlons $Z$ and $X, R_{2 z}(\bar{k})$, denned by

$$
R_{i x}(\bar{\kappa})=\left|S_{P_{z}^{\prime} P_{z}}(\bar{\kappa}) / S_{P_{x}^{\prime} P_{x}}(\bar{\kappa})\right|
$$

measures the relative Importance of the two force components. In Eq. 6.76. $S_{P_{:},:}(\bar{x})$ Is ine cross spectrum of the nodal loads, evaluated using the directlonal. spectrum model, when both degrees of freedom $i$ and $m$ are in the $Z$ directlon, l.e. 


$$
S_{1, l}(\bar{\kappa})=S_{1 ! m}(\bar{k}) \quad \text { for } z / / Z \text { and } m ! ! Z
$$

similarly.

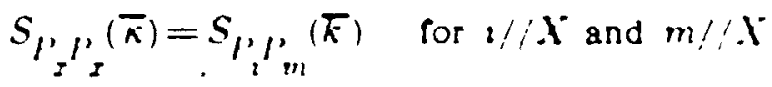

The ratlo $R_{z z}(\bar{k})$ depends on, among other parameters, the mean direction of wave advance. When evaluated at $\bar{\theta}=0, R_{z I}(\bar{k})$ gtres the ratlo of the spectrum of across vive forces to that of along wave forces.

Flg. 6.6 shows the varlation in $R_{i \dot{j}}(\bar{k})$ with $\bar{\theta}$ for 3 different values of $\bar{a}$ at $\bar{k}=0.3$. The rano $R_{i s}(\bar{K})$ decreases with the increase in $\bar{a}$ (notlce that higher values of $\bar{a}$ Indlcate a narrower angular spread) for $\bar{\theta}<45^{\circ}$. For such angles. the $X$ component is larger than the $Z$ component for any one Indlvidual wave and a narrower angular distribution means that a larger percentage of wave energy is contalned In waves advancing in directlons close to angle $\bar{\theta}$. Conversely. $R_{z x}(\bar{k})$ Increases with $\bar{a}$ for $\bar{a}>45^{\circ} . R_{2 x}(\bar{k})$ reaches a maximum value at $\bar{\forall}=90^{\circ}$, as the mean direction of wave advance lles along the $Z$ axls. It could be seen that at $\bar{\theta}=0^{\circ}, R_{i x}(\bar{k}) \cdot$ is small for the narrower angular spreads.

Shown in Fig. 6.7 is the varlation in $R_{z x}(\bar{k})$ evaluated at $\bar{\theta}=0^{\circ}$ with the dimenslonless wave number $\bar{k}$ for 3 different values of $\bar{a}$. The ratlo of across wave forces to alond wave forces Increases with the Increase in $\bar{k}$, l.e. for shorter wave lengths, due to the broader angular spread assoclated with shorter wave lengths, Eq. 6.20. It can also be notlced that $R_{z x}(\bar{k})$ evaluated at $\bar{F}=0^{\circ}$ decreases for narrower angular dlstrlbutlons (higher values of $\bar{a}$ ) as expected.

The varlation in $R_{z x}(\bar{k})^{\prime}$ wlth the angular spread parameter $\bar{a}$, for $\bar{\theta}=0^{\circ}$ and 3 values of $\bar{k}$, is shown in $F$ I\&. 6.8. It is notlced that at $\bar{a}=0$, both force 


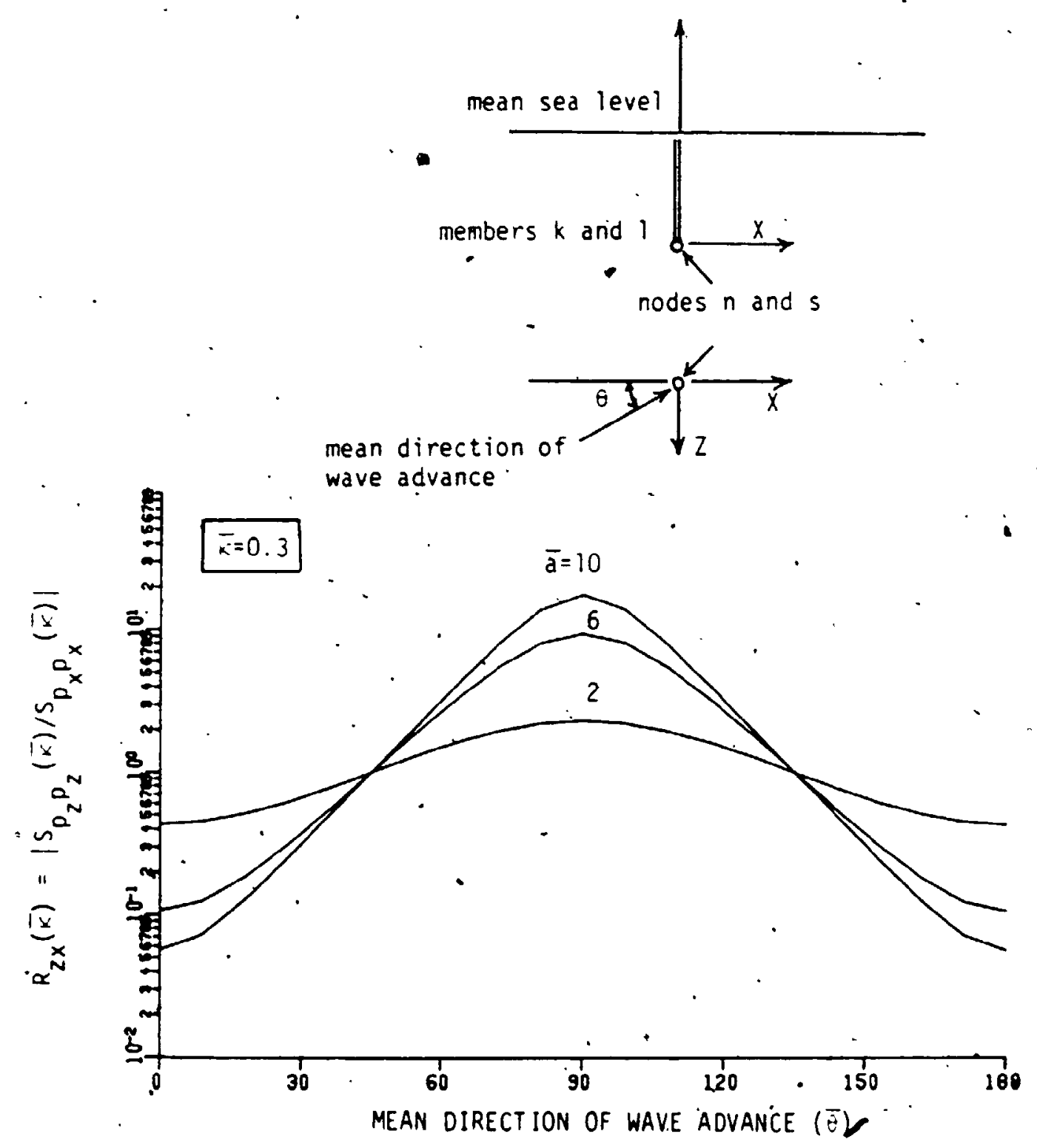

Figure 6-6: Vartátion In the Ratlo of the Spectra of Lateral Force Components with Mean Directlon or Wave Advance (Directlonal Spectrum Model) 
$-247$ 
components are equal as the wave energy is distributed equally among all frequencles. The ratlo $R_{i x}(k)$ decreases with the Increase in $\bar{a}$. Estimates for the values of $\bar{a}$ based on experimental results of full scale measurements have not yet been rellably establlshed. Berge [181] used values of $\bar{a}$ ranging from $a=4$, to $\dot{a}=100$ to evaluate the response of an offshore wower io three dimenstonal waves.

Fig. 6.9 shows the varlation in $R_{z i}(\bar{k})$ with $\bar{\theta}$, for 3 different values of $\bar{a}$. $\bar{K}=0.3$ and $\overline{x^{\circ}} 4^{\circ}$. It is notlced that the narrower the angular spread is (hlgher values of $\bar{a}$ ). the tess the reduction in wave forces thigher values of $\left.\bar{R}_{I}(\bar{k})\right)$. The largest reduction occurs at $\bar{\theta}=45^{\circ}$ for all values of $\bar{a}$. This is because at $\bar{\delta}=45^{\circ}$. the spectrum of the force component in the $X$ direction at a certaln frequency. for both models. contalns half the total energy of the wave system at that frequency.

\subsubsection{Reduction in Along Wave Forces Due to Directional Spread}

Spectra of wave forces exerted by a fully correlated unldirectional wave system are formulated simllar to those of a directlonal one and the nnal general expression is glven in Appendix $C$. The reduction in the wave force spectrum due to directional spread can be measured by the reduction factor $\mathbf{R}_{f}(\bar{k})$ denined as

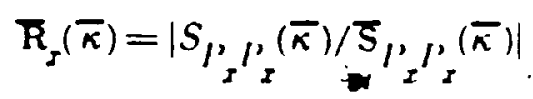

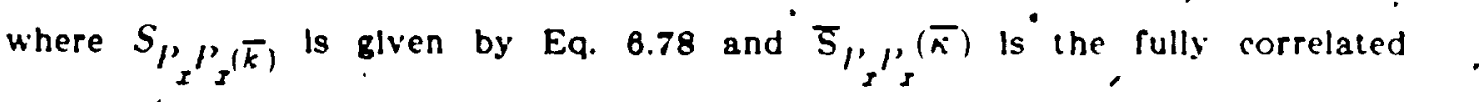
unidirectional model, Eq. C-1. The reduation factor $\mathbf{R}_{I}(\hbar)$ enaluated at $\bar{\theta}=0^{\circ}$ represents the reduction in along wave forces.

In Flg. 6.10, the variation in the reduction factor for along wave forces $\left(\mathbf{R}_{s}(\bar{k})\right.$ at $\left.\bar{\theta}=0^{\circ}\right)$ with dimensionless wave number $\bar{k}$ is plotted for 3 different values of $\vec{a}$. The reduction factor'decreases with the increase in angular opread and lis varlation with the dimensionless frequency is mild. 


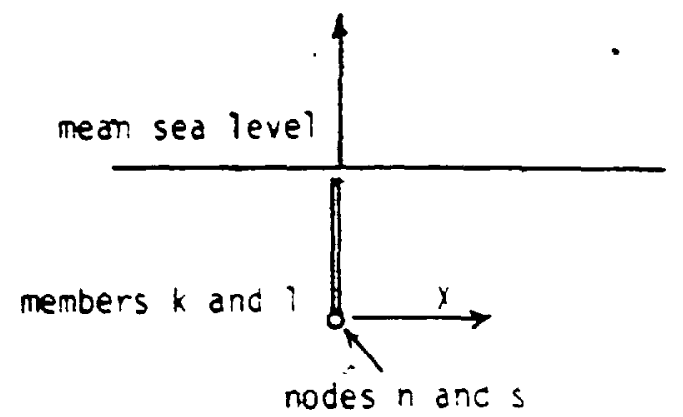

mean direction of

wave advance
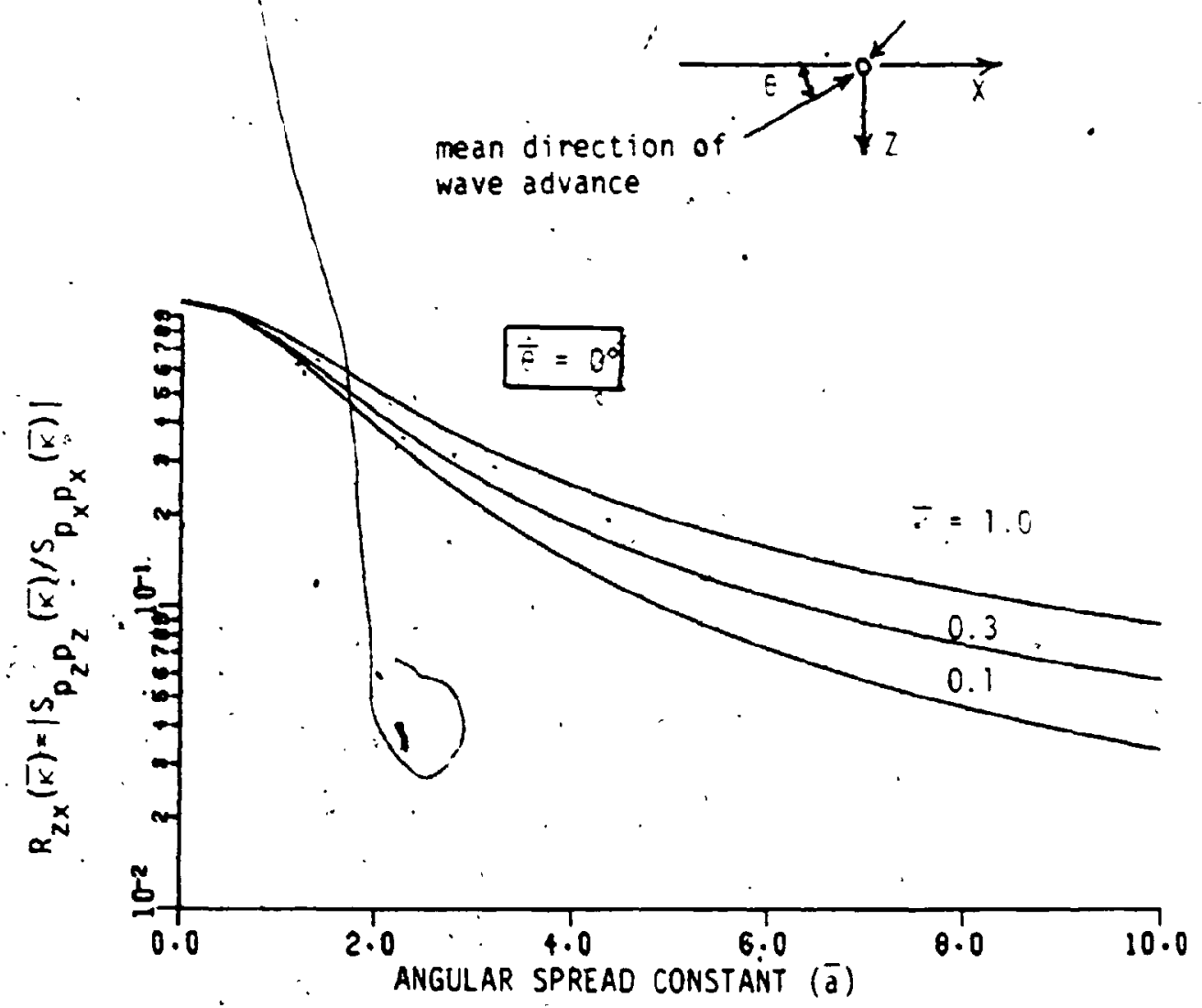

Figure 6-8:. Varlation In the Ratlo of the Spectra of Across Wave to Along Wave Force Components with Angular Spread (Directional Spéctrum Model) 


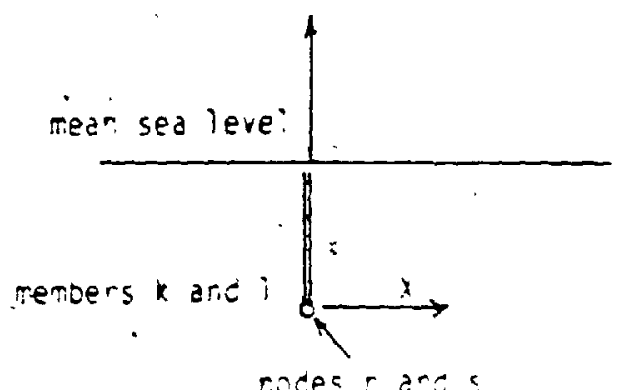

mean cirection $0^{*} \rightarrow$

wave aovance

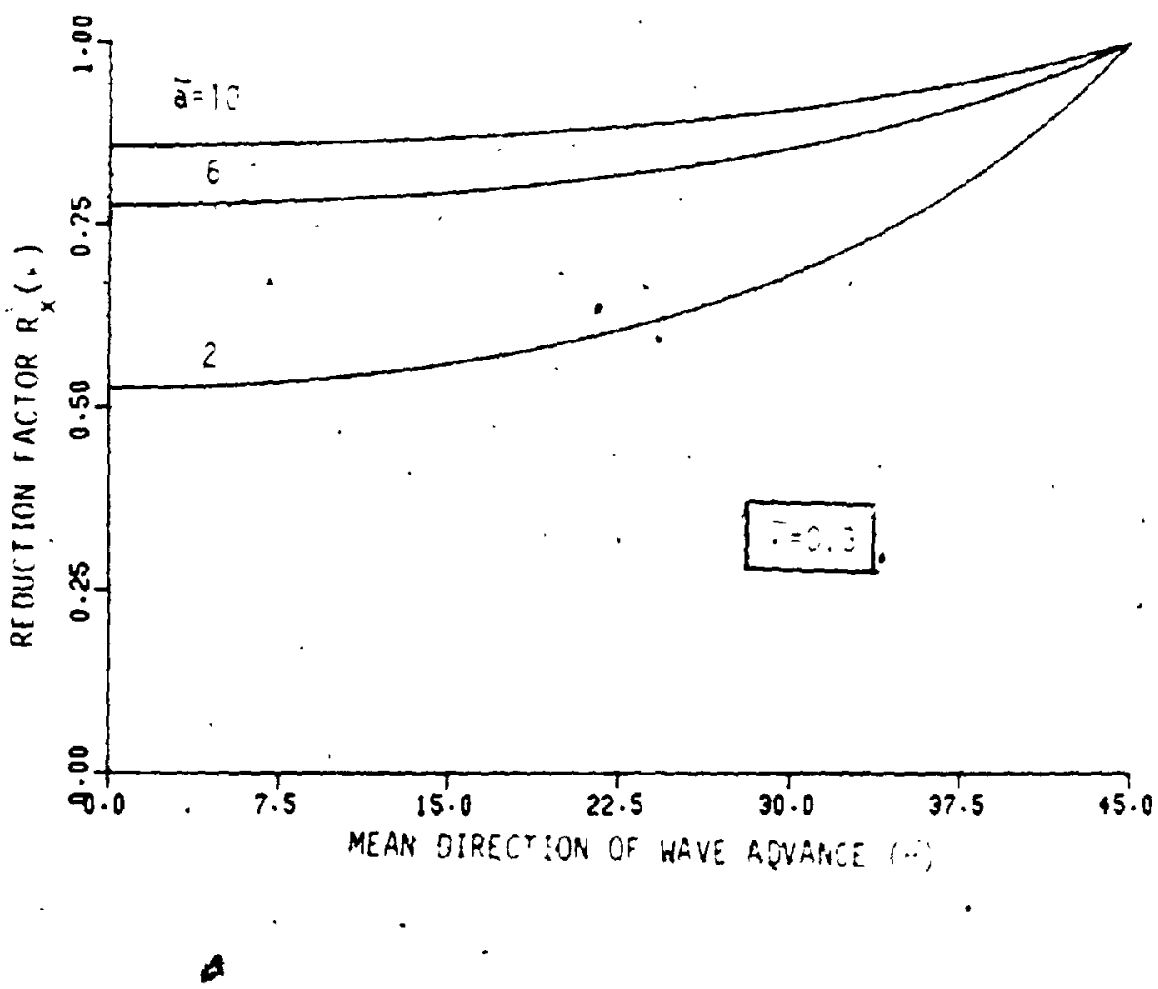

Figure 6-8: V'arlation in the Reduction of the Spectrum of Force Component in the $X$ Direction with Mean Dlrection of War. Adrance (Directlonal Spectrum Mode! 


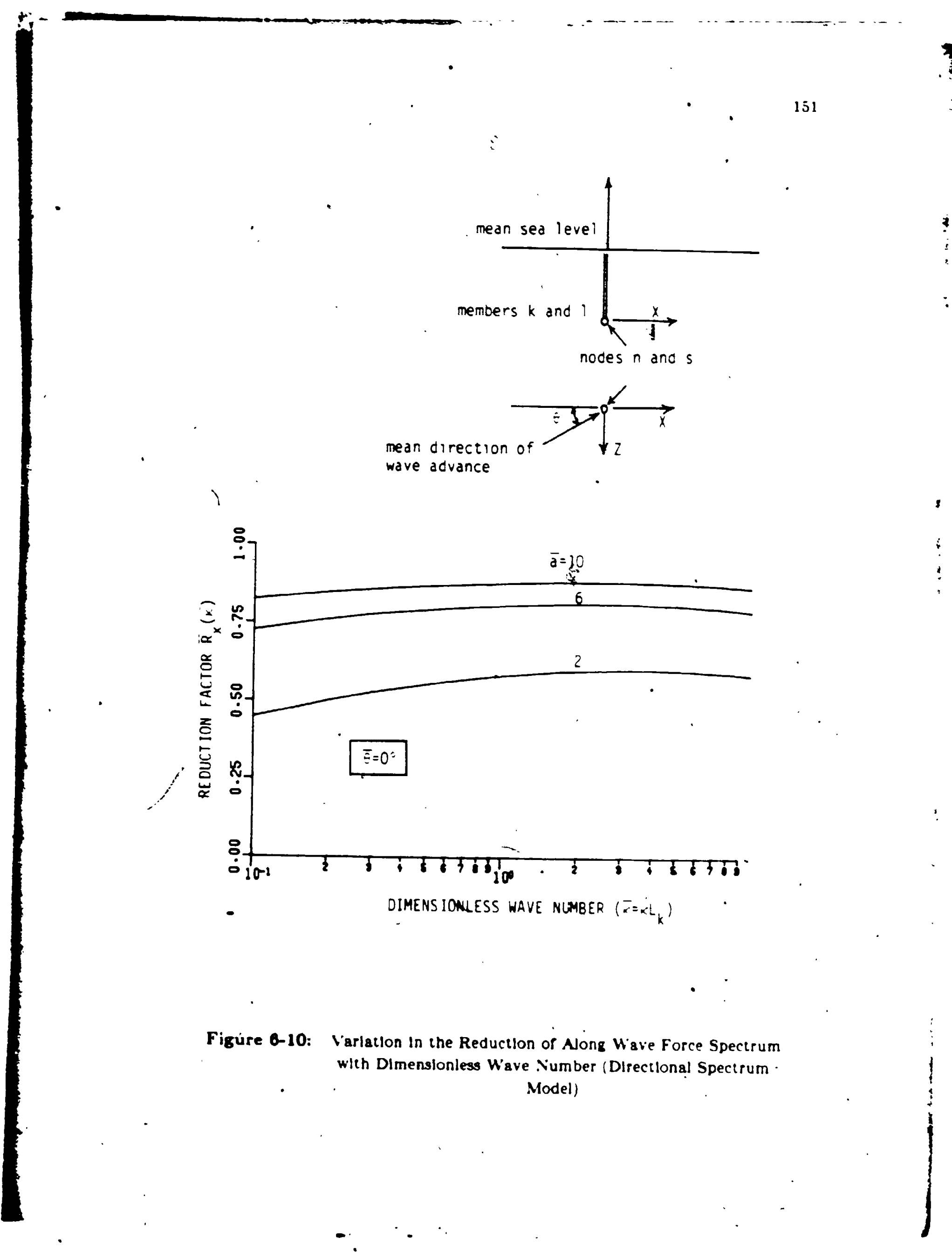




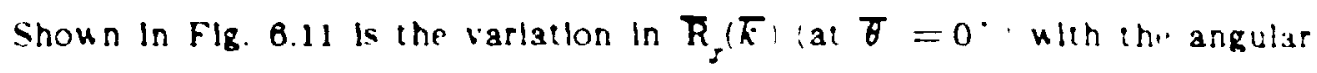
spread parameter $\bar{a}$. for 3 values of $\bar{E} \bar{R}_{s}(\bar{k})$ Increases ulth the lncrease in $\bar{a}$ and would reach the upper llmil of 1 for $\bar{a} \rightarrow x$ Indicating that all the wate energy is concentrated at $\theta=\bar{\theta}$. For $\bar{k}=0.3 . \mathbf{R}_{f}, \bar{F}$, has the highest values because the narrowest angular distribution among the three curves Is atworlated wlth the one for $R_{s}(\bar{k})=0.3$.

\subsubsection{Effect of Lumping the Members at the Noded}

For offshore structures with many members of general ortentation. such as the Jacket type structures. cross spectra of water particle velocltles are usually approximated by thelr values at the nodes $S_{i_{1}}{ }_{2}\left(\omega_{0}\right)_{0}$ and the areas and volumes of members connected to a Jolnt are lumped at thls jolnt. In thls case. the Integrations In Eq. 6.84 are replaced by simple multiplications 1.e.

$$
I_{k l}=S_{i_{1} i_{2}}(-)_{0} L_{k} L_{l}
$$

The expresslons for $I_{k l}$ for thls case are given in Appepdix D for different representations of the waive system. The accuracy of such approxlmatlon can be measured by the ratlo $R_{z_{0}}$ given by

$$
R_{s_{0}}=S_{r_{z} r_{z}}(\bar{\alpha})_{0} / S_{r_{z} r_{z}}(\bar{k})_{\text {. }}
$$

In Eq. 6.81. $S_{P_{x} P_{x}}(E)$ is the cross spectrum of wave forces In the $x$ direction for a directional wave system and $S_{P_{z} P_{Z}}(\bar{k})_{0}$ is the cross spectrum of the same quantlles calculated for a directlonal uave system obtalned by approximating the veloclty along the member by its value at the node.

The ratlo $R_{z}$ is examined for a vectical member located above nodes $n$ and s. It can be shown that the ratlo $R_{s_{o}}$ for vertical members does not depend on the angular distribution parameier and depends solely on $\bar{k}$. This dependency is shown in F!g. 6.12. For small dimenslonless wave numbers (longer wave lengihs) 

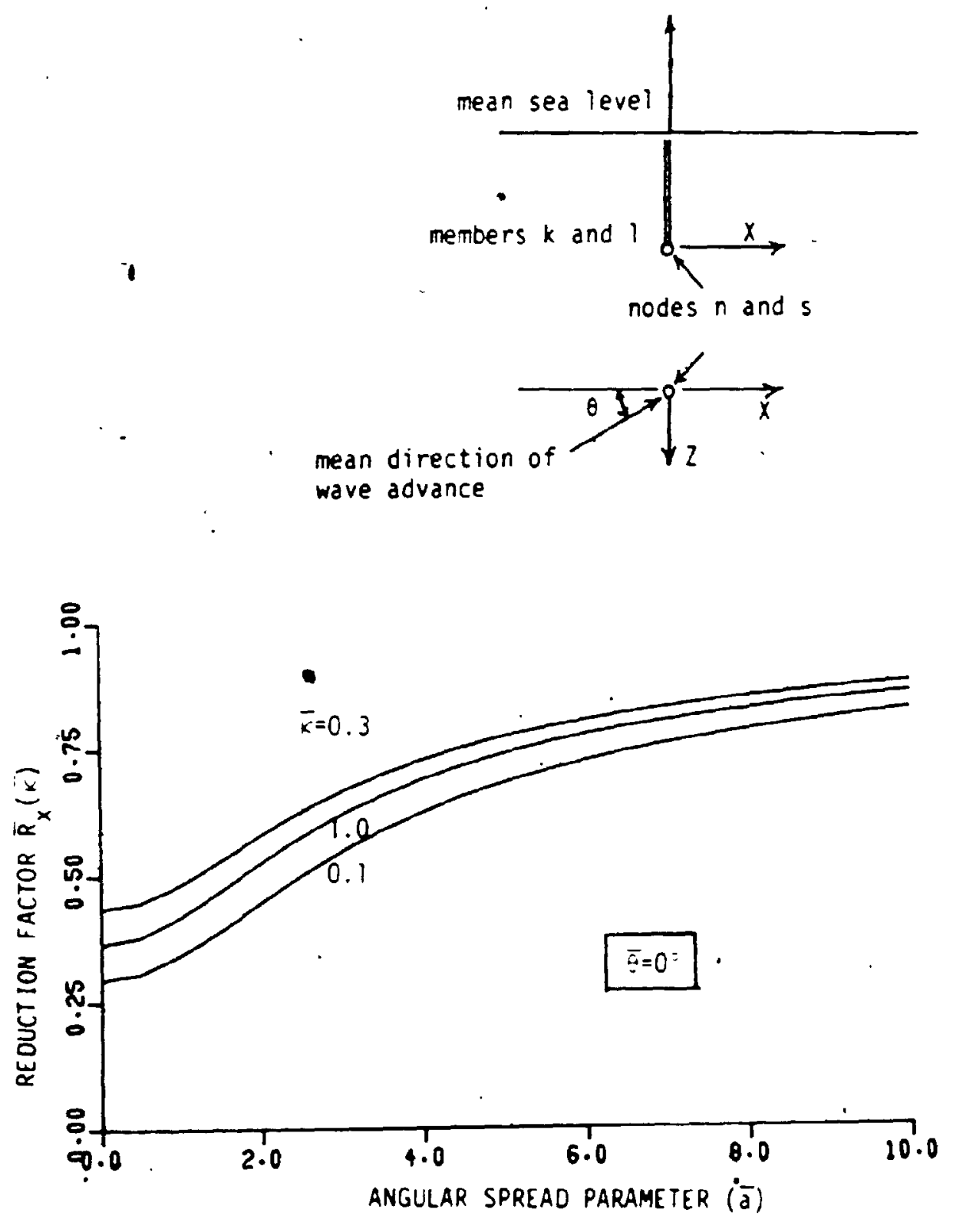

Figure 6-11: Varlation in the Reduction of Along Wave Force Spectrum with Directlonal Spread (Directlonal Spectrum Model) 


$R_{x_{0}}$ approaches folty. It decreajes moderately with the increase in $\bar{k}$ reaching a decreases rapldly with $\bar{k}$ to reach several orders of magnitude less than unlty at $\bar{k}=10.0$. The sharp decrease is explained by the fact that for higher $\bar{k}$ (shorter wave lengths), the deep water approximations hold and the veloclty pronle varles almost exponentlally with depth.

\subsection{Coherence Function Model}

\subsubsection{Formulation}

In Section 6.3.2.2, the lack of spatlal correlation observed in short crested seas is accounted for by the use of a coherence function and the water partcle kInematlcs spectra are glven. by Eq. 6.48. The coherence function expressed by Eq. 6.48 is plotted in Fig. 6.A. for dirferent values of the exponential decay - parameter $c$. It can be seen that the coherence decays faster for higher values of c. The value of $c$ may vary with types of waves or direction of separation but it Is assumed constant in thls study to simplity the analysis.

When polnts (1) and (2) are in general postitons, the coherence function is given by

$$
R=e \frac{-r}{\lambda} \sqrt{\Delta x^{2}+\Delta y^{2}+\Delta z^{2}}
$$

where

$$
\begin{aligned}
& \Delta x=|x 1-x 2| \\
& \Delta y=|y 1-y 2| \\
& \Delta z=|z|-z 2 \mid
\end{aligned}
$$

However, If the coherence function glven by Eq. 6.82 is used to evaluate the Integrals $I_{k l}$ of Eq. 6.64. they do not decouple. A llnearized form of the square root In Eq. 6.82 was suggested that allows the Integrations to decouple [163]

$$
R=e^{-\frac{r}{\lambda}(\Delta x+\Delta y+\Delta z)}
$$




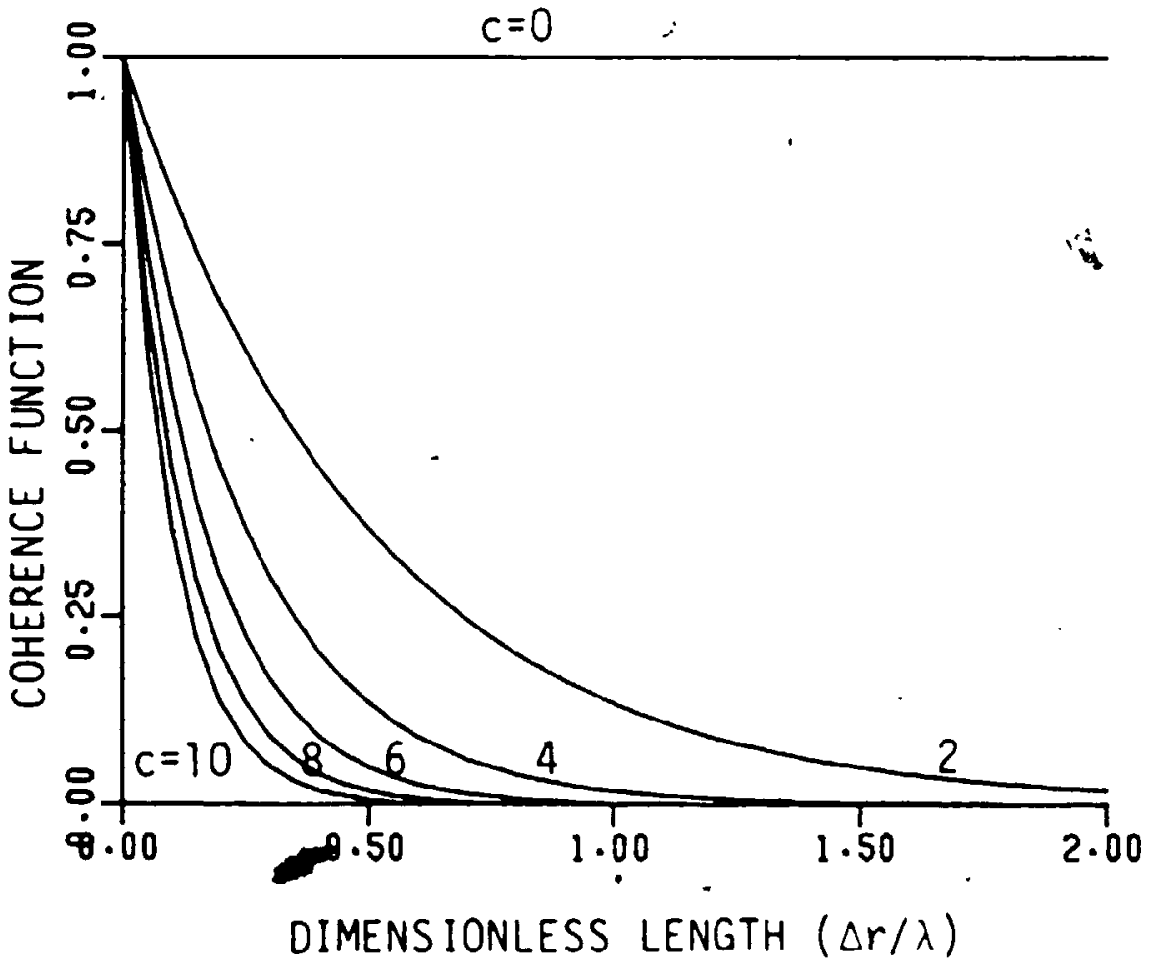

Figure 6-13: Fxponentlal Decay' Coherence Function 
where $\gamma$ is a correction factor that depends on the orlentation of the llne Joining the 2 polnts. If $\Delta x=\Delta y=\Delta z$ then $\gamma=0.5772$ whlle if the line Jolning the 2 polnts is parallel to any of the three global axes then $?=1$. For all other orlentatlons 7 takes on a value between 0.5772 and 1 .

Evaluation of the Integrals $I_{k l}$ for the coherence function model is lengthy and only an outline of how the integrations are carrled out is given below. The general nnal expressions for the integrals is given in Appendix E.

Conslder a wave system advancing in a mean directlon that makes an angle $\nabla$ with the $X$ axts. From Eqs. 6.46, 6.48 and 6.84 , the cross spectral density of water particle velocitles follows as

$$
\begin{aligned}
& S_{i_{1} i_{2}}(\omega)=\omega^{2} \frac{\bar{S}_{h h}(\omega)}{\sinh ^{2} \kappa D} C l(\delta) C 2(\bar{\theta}) \\
& . H Y P_{1}|\kappa(y 1+D)| H Y P_{2}[\kappa(y 2+D) \mid \\
& . e^{i x \mid(x)-x 2) \cos \bar{\theta}+(z 1-z 2) \sin \bar{\theta}:} \\
& e^{\left.-\frac{\gamma}{\lambda}|x 1-x 2|+|y|-y 2|+| z 1-z 2 \mid\right)}
\end{aligned}
$$

where $C_{1}(\bar{\theta})$ and $C_{2}(\bar{\theta})$ are given by Eq. 0.11 if $\theta$ is substltuted by $\bar{\theta}$ and $\left.H Y P_{1} \mid \kappa(y 1+D)\right]$ and $H Y P_{2}|\kappa(y 2+D)|$ are given by Eqs. 6.42 and 6.43 . respectlvely. Noting that $\lambda=2 \pi / \kappa$ and substltuting by Eq. 6.65. Eq. 6.85 becomes 


$$
\begin{aligned}
& s_{i_{1} i_{2}}(\omega)=\frac{5}{4} C_{1}(\delta) C_{2}(\delta) A_{n s} \\
& . \exp \left\{i \kappa i\left(p_{k} \cos \theta+r_{k} \sin \theta\right) S_{k}-\left(p_{l} \cos \theta+r r_{i} \ln \theta\right) S_{l}\right\} \\
& \left.. H Y P_{1} \mid A_{n}+\kappa q_{k} S_{k}\right] H Y P_{2}\left[1_{k}+\kappa q_{l} S_{l} !\right. \\
& \exp \left\{-\underset{2 \pi}{\kappa i} \mid p_{k} S_{k}-p_{l} S_{l}+x_{n}-I_{n}\right\} \\
& . \exp \left\{-\frac{\kappa \Upsilon}{2 \pi}\left|q_{k} S_{k}-q_{l} S_{l}+y_{n}-y_{k}\right|\right\} \\
& \exp \left\{-\frac{\kappa \gamma}{2 \pi}\left|r_{k} S_{k}-r_{l} S_{l}+z_{n}-z_{i}\right|\right\}
\end{aligned}
$$

where $\zeta_{,} A_{n}$ and $A_{s}$ are glven by Eqs. $6.70,6.68$ and 6.69 , respectlvely. $A_{n .}$ Is glven by Eq. 6.73 if $\theta$ is substltuted by $\bar{\theta}$. When carrying out the. Integrations in Eq. 6.64. the dimculty lles in the exponentlal terms with the absolute values. The treatment of the absolute value terms is sllghty different when the nodes $n$ and $s$ colnclde than when they do not and each case will be demonstrated separately.

A) Nodes $n$ and : coincide: A dimculty arlses if one or more of the three palrs of direction cosines ( $p_{k}$ and $p_{l}, q_{k}$ and $q_{l}$ and $r_{k}$ and $r_{l}$ ) have the same slgn. In this investigation, the-integrations are carrled out for the case of only one palr having the same slen. Nithough it is posslble to carry out the Integrations for the cage of two or three palrs having Identlcal signs, the resulting expressions become extremely lengthy and a reasonable approximation is necessary. For the case of one palr of direction cosines having Identical signs, the integrations have, to be pentormed on two Intervals for one of the Independent varlables.

On the other hand. If each of the three palrs of the directlon cosines have different signs, the integrations are carrled out on one Interival for each of the Independent varlables. 
1) One palr of the direction cosines have the same sign: In this case, the expanston of the absolute value terms is given by

$$
\left|b_{k} S_{k}-b_{l} S_{l}\right|=\left\{\begin{array}{l}
\left|b_{k}\right| S_{k}-\left|b_{l}\right| S_{l} \text { for } 0<S_{l}<b_{l} S_{k} \\
\left|b_{l}\right| S_{l}-\left|b_{k}\right| S_{k} \text { for } b_{l} S_{k}<S_{l}<L_{l}
\end{array}\right.
$$

where $b_{k}$ and $b_{t}$ refer to the palr of direction cosines with the Identical signs and $b$, Is given by

$$
b_{r}=b_{k} / b_{1}
$$

Eq. 6.87 glves the expansion for the palr with Identical signs, whereas those of the palrs with opposite slgns are glven by

$$
\left|b_{k} S_{k}-b_{l} S_{l}\right|=\left|b_{k}\right| S_{k}+\left|b_{l}\right| S_{l}
$$

By using Eqs. 6.87 and 6.88 , the double Integral in Eq. 6.64 is nist carrled out with respect to $S_{l}$ on two Intervals; $0 \rightarrow b_{r} S_{k}$ and $b_{r} S_{k} \rightarrow L_{l}$ and then Integrated with respect to $S_{k}$ from $0 \rightarrow L_{k}$ : Closed form solutions are obtalned and no numerical Integration is required.

2)Two or three palrs of direction cosines have the same sign: thls case arises only when evaluating $I_{k k}$ for a member which is not parallel to any of the global axes. In such case, the Integration is approximated by that of an equlvalent member that has the same propertles but lles parallel to one of the global axes. The direction of the equivalent member is chosen so as $10^{\circ}$ minimize the error Introduced by the approximation.

3)Each of the three palrs of alrection cosines has opposite signs: the expanston of the absolute value terms is glvén by Eq. 6.89 and the double Integration in Eq. 6.64 ts cafrled out ion one interval for each of the independent varlables.

B)Nodea n and - Do Not Coincide: two dirterent sltuatlons can be dlstingulshed 
1) $l_{k l}$ !s eyaluated on one Interval for each variable: this situation arlses when each or the three absolute value terms salisnes elther of the following conditions:

A) $\left|\Psi_{n}-\Psi_{g}\right|>0$ : where $\Psi$ refers to any of the global coordinates $x y$ or $z$. In this case, the expansion of the absolute value terms is glventy

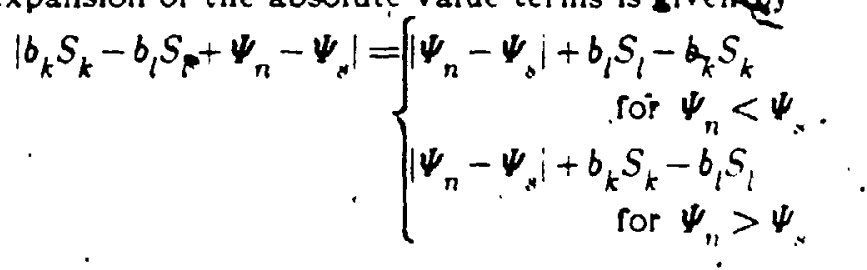

where $b_{k}$ and $b_{1}$ are the direction cosines assoclated with the global coordinate $\psi$. l.e if $\Psi \equiv x$ then $b_{k} \equiv p_{k}$ and $b_{l} \equiv p_{l}$.

B) $\left|\boldsymbol{\Psi}_{n}-\boldsymbol{\Psi}_{\boldsymbol{z}}\right|=0$ and $b_{k}$ and $b_{l}$ have opposite signs. The expansion of the absolute value terms is glven by Eq. 6.89 .

2) $I_{k l}$ is evaluated on two Intervals for one of the Independent varlables; thls sltuation arises if any of the three absolute value terms satisnes the following condliton:

$\left|\Psi_{n}-\Psi_{j}\right|=0$ and $b_{k}$ and $b_{p}$ have Ideacteal slgns

- The expanslon of the absolute value terms is glven by Eq. 6.87.

\subsubsection{Parametric Study}

The spectra of wave forces evaluated by the coherence function model depend on $C_{D}$ and $C_{M}$ as well as two groups of parameters:

1. Geometerlc Parameters and Wind Speed: these are the same as for the directional spectrum Section 6.5.2.

2. Wave Sygtem Parameters: these are the dimensionless wave number $\bar{K}$. exponentlal decay parameter $c$ and mean directlon of wave advance 7 . 
A parametric study is carried out to examine the varlation of the spectra of wave forces estlmated using the coherence function model with each of the parameters of the second group. As in the directlonal spectruff model. three quantltles are examlned:

1. The ratlo between the two horlzontal force components.

2. The reduction of atong wave forces due to lack of spatlal correlation.

3. The error introduced by assuming the cross spectrum of water partlcle veloclty to be constant and equal to that at the nodes.

Orlentation of the members for whlch the wave forces are evaluated is Illustrated on the corresponding ngures showing the results of the calculation. The values of the parameters of the nrst group that are used In the parametric study are the same as those used In Section 6.5.2, unless otherwlse stated.

\subsubsection{Variation in the Ratio Between the Horizontal Force Componento With The Wave. System Parametero}

SInce the coherence function model is essentlally a unldirectional model, it may fall to represent the force component normal to the mean direction of wave advance. However, it properly represents the ratlo between the 2 horizontal force components. Thls is lllustrated by Fig. 6.14 where the ratlo between the horlzontal force components, $R_{z x}(\bar{k})$, defned by Eq. 6.76 and evaluated using the coherence function model is plotted for $\bar{\delta}=0^{\circ}$ to $180^{\circ}$. (For a vertical member, $R_{z x}(\bar{k})$ is independent of the exponentlal decay payameter $\left.c\right)$. As $\therefore$ $\bar{\nabla} \rightarrow 0^{\circ}, F_{z} \rightarrow 0$ and $R_{z z}(\bar{k}) \rightarrow 0$, whlle as $\bar{\sigma} \rightarrow \infty 0^{\circ}, F_{z} \rightarrow 0$ and $R_{z z}(\bar{k}) \rightarrow \infty$. Nevertheless, for $\$ \rightarrow 0$, the $F_{z}$ force component evaluated by the directlonal spectrum is already small compared to $F_{x}$ and as $\dot{\forall}$ increases, $R_{z x}(\bar{k})$ Increases show!ng an Increased relatlve Importance of $F_{z}$ in comparlson to $F_{2}$, Fig. B.6.2. Thus, the ratlo $R_{z x}(\bar{k})$ evaluated -using the coherence function model, is 


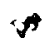<smiles>CCCCCCCCCCC</smiles>

162
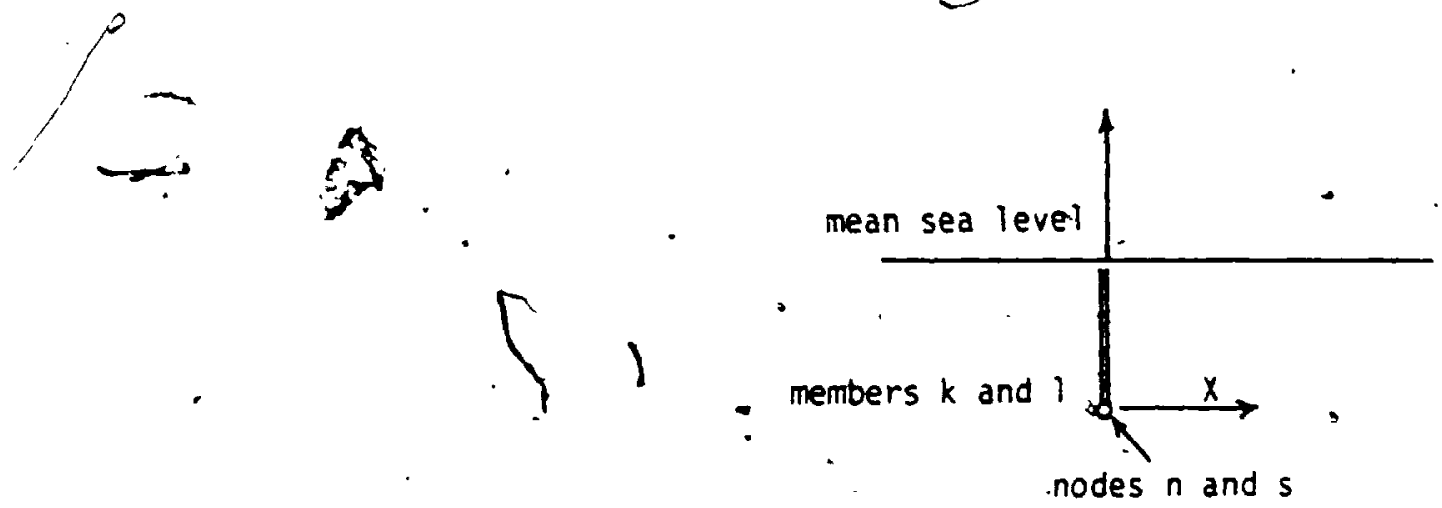

mean direction of

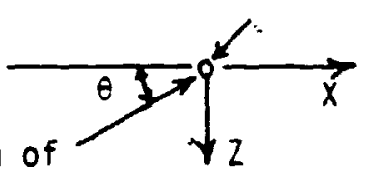
wave advance

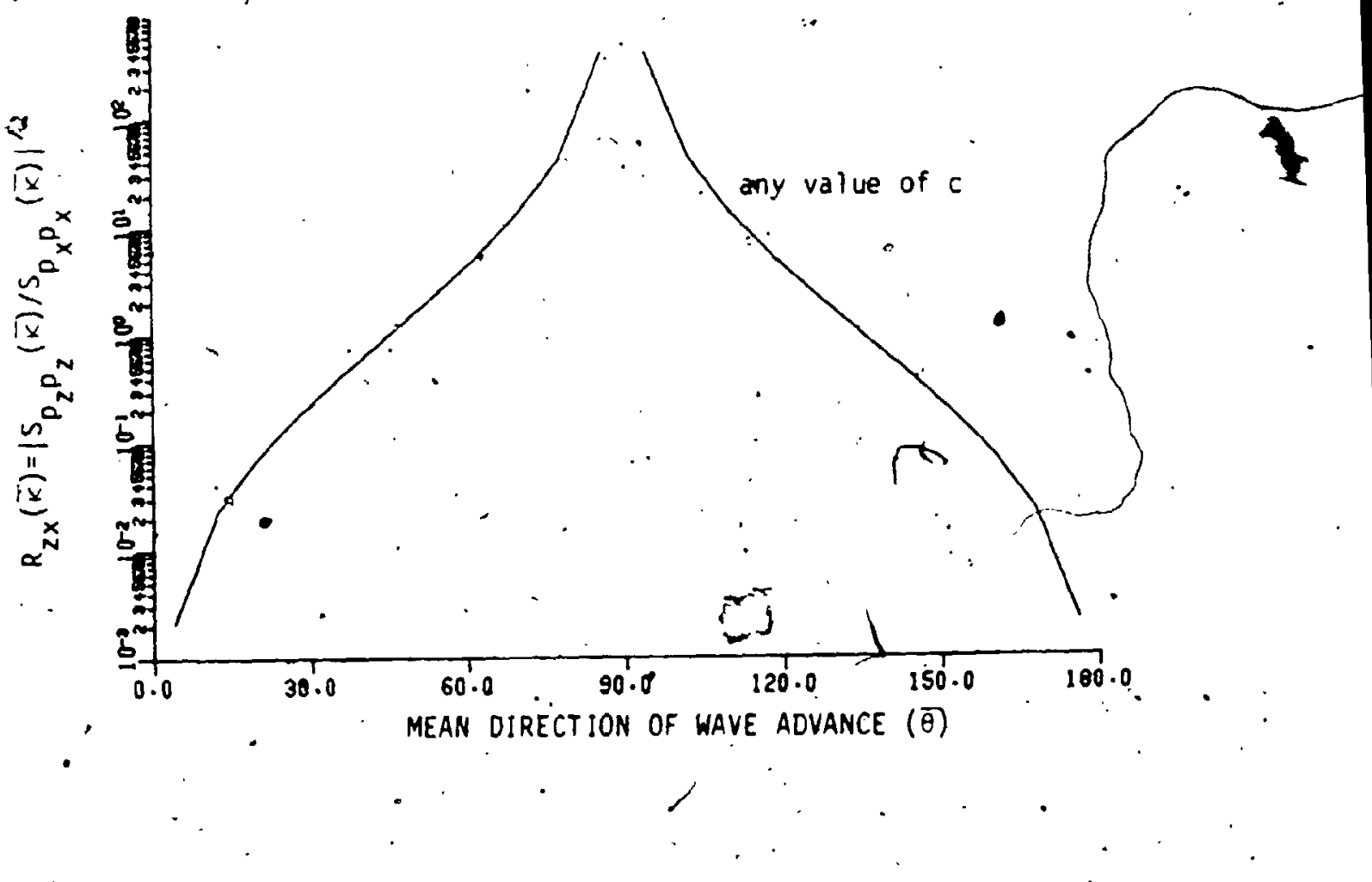

Figure 6-14: Variation id the Ray fo of Spectra of the Lateral Force - Components with MeaniDirection of Wave Advance (Coherence Function Model) 
Improperly represented only at angles where one of the two horizonital force components is small and could be neglected. Fig. 6.15 shows $R_{z z}(\bar{k})$ for both models $(\bar{a}=10$ for the directlonal spectrum model and any value of $c$ for the coherence function model). It can be notlced that for the range of $\bar{\theta}$ between $15^{\circ}$ and $75^{\circ}$, where both components are Important both models glve close values for $R_{z x}(\bar{k})$.

- For vertical members, the ratto $R_{z z}(\bar{k})$ is independent of the parameter c as shown in Fig. 8.16 where $R_{z x}(\bar{k})$ is plotted for 3 different velues of $\bar{k}$. It can alse. be seen that $R_{z z}(\bar{k})$ is smaller for longer wave lengths. In Fig. 6.17. $R_{z z}(\bar{k})$ is plotted for $\bar{\theta}=22.5^{\circ}$, agalnst the dimensionless wave number $\bar{k}$. The increase in $R_{z z}(\bar{k})$ with $\bar{k}$ is solely due to the Incresse in the ratlo $G_{k !}^{\prime} / G_{k_{z}}$. Eq. 6.62 . since $I_{k_{z} l_{z}} / I_{k_{x} l_{x}}$ for vertlcal members depend entirely on the angle $\bar{\nabla}$.

\subsubsection{Reduction in Along Wave Forces Due to Lack of Spatial}

\section{- Correlation}

As the distance between any 2 points in the wave neld Increases, the correlatlon between water particle klnematles at these polnts decreases and this is characterized by a decrease in their coherency. Consequently, the resultant wave rórces decrease and thls is represented. for wave forces in the ' $X$ direction, by the reduction factor $\mathbf{R}_{x}(\bar{k})$ deflned by Eq. 6.78 .

Flg. 6.18 shows the varlation in $R_{I}(\bar{k})$ with the constant $c$ for 2 members extending ang the vertical axls calculated for $\bar{Z}=0^{\circ}$ and 3 different values of $\mathbb{R}$. The results shown in.Fig 6.18 are for 2 colncldent nodes. For smaller values of $c$. the correlation length is large and even for shorter wave lengths $(\bar{k}=1.0)$ is stlll larger than the member lenith and the wave forces are well correlated glving values of $\boldsymbol{R}_{2}(\bar{k})$ approaching unity. As $c$ increases, the correlation between forces 

165

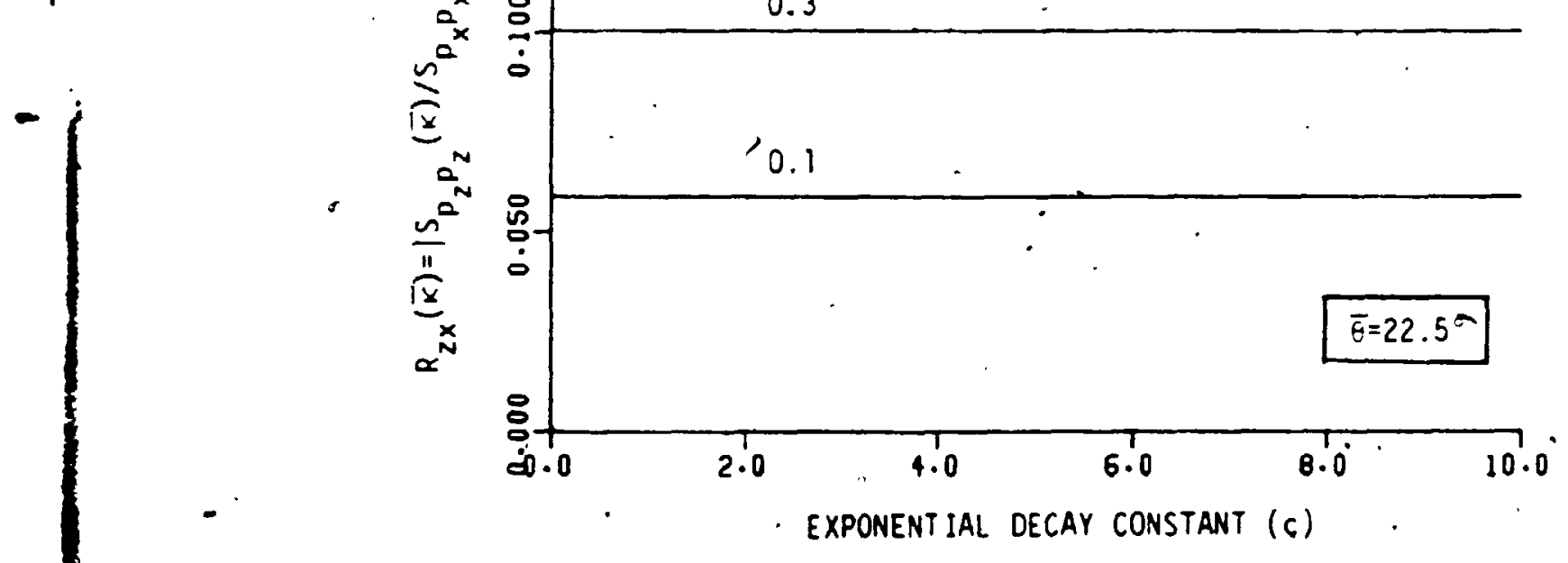

Figure 6-16: Variation in the Ratio of Spectra of the Lateral Force Components with Exponential Decay Constant (Coherence Function Model) 


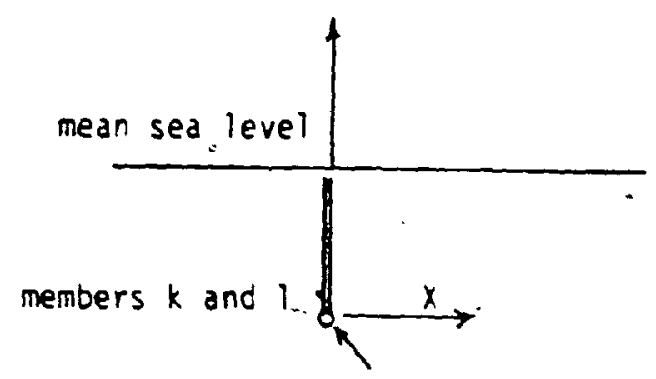

nodes $n$ and $s$

wave advance

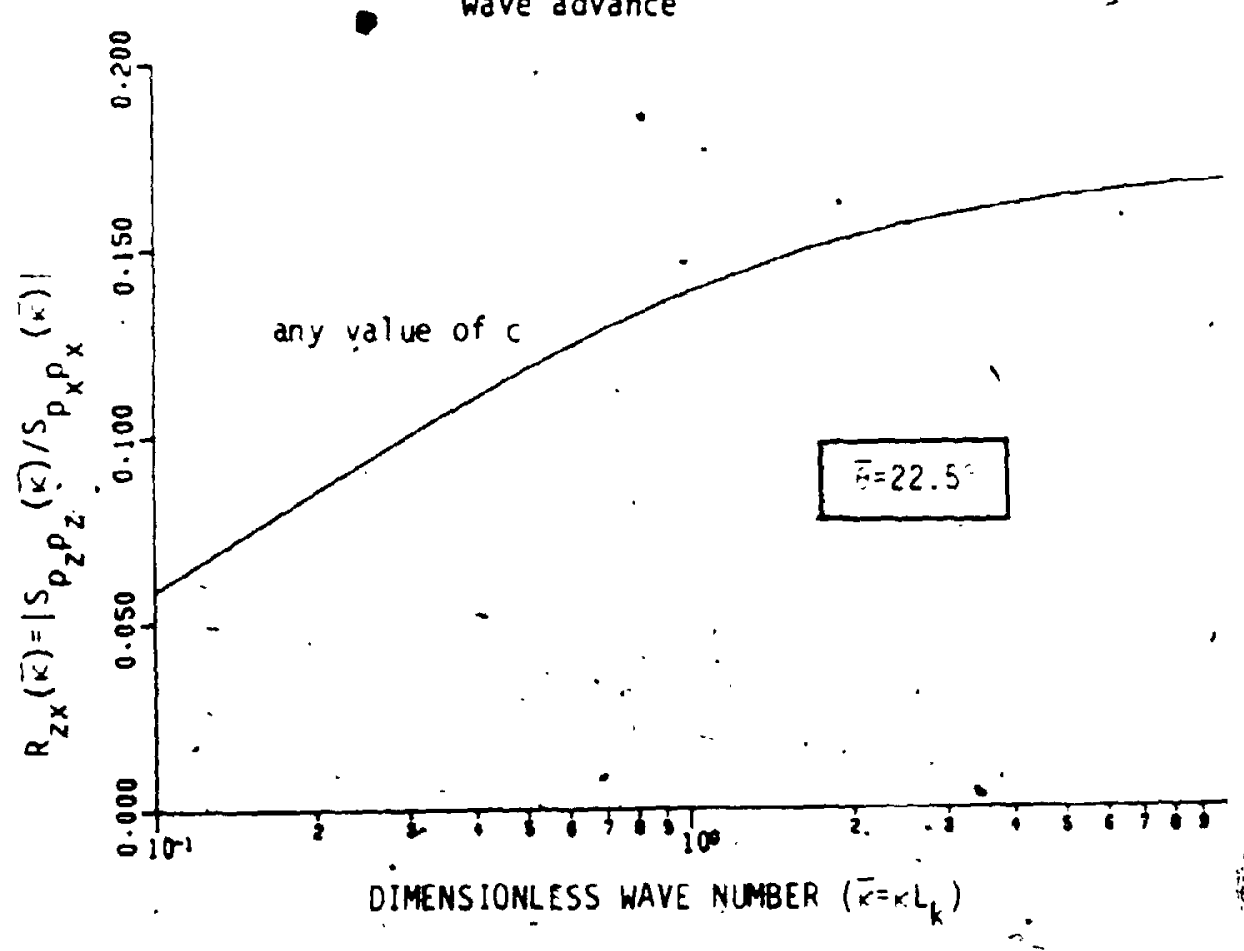

Figure 6-17: Varlation. In the Ratlo of the Spectra of Lateral Force Components with Dimensionless Wave Number (Coherence Function Model) 

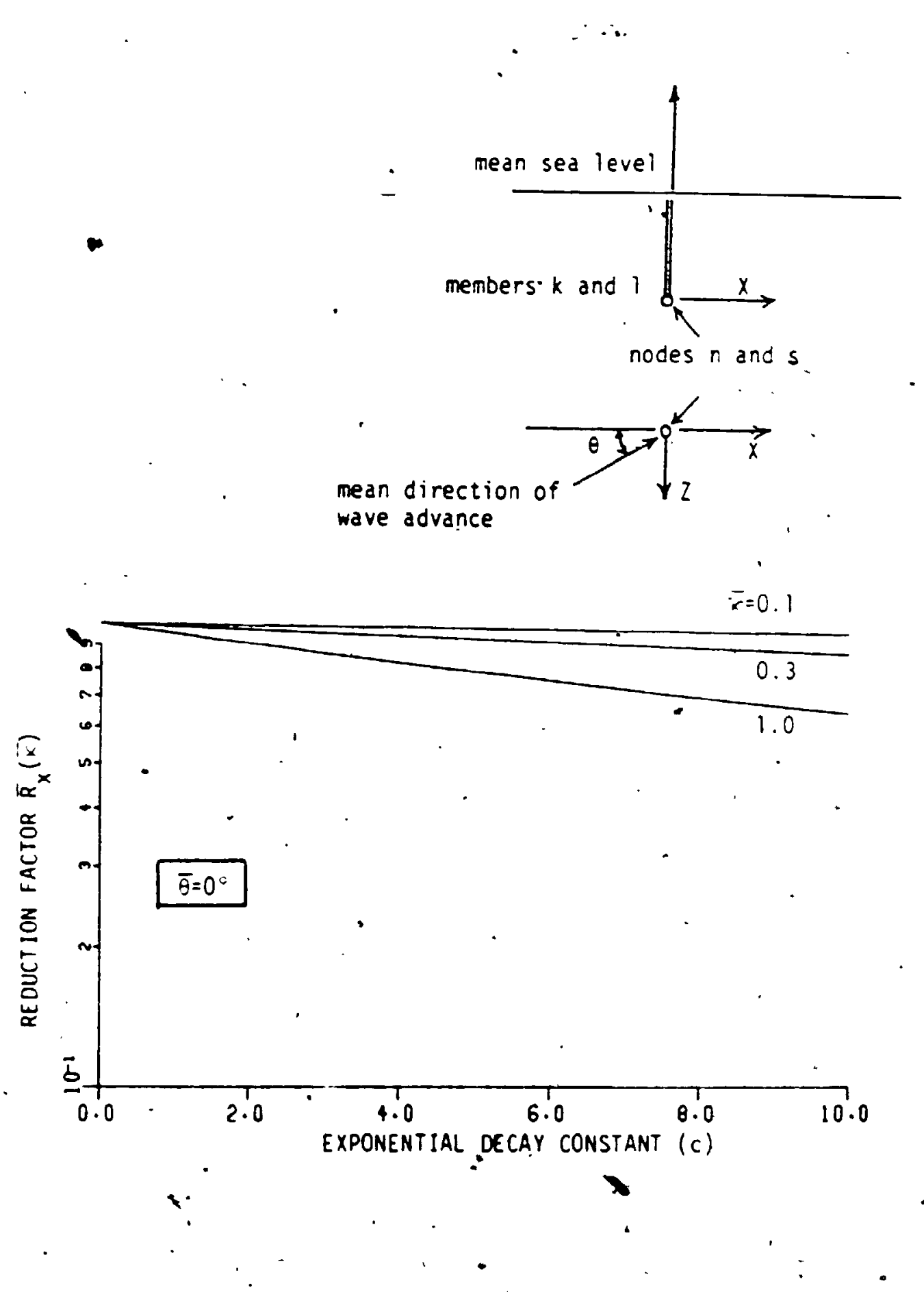

Figure 8-18: Varlation In the Reduction of Alone Wave Force Spectrum with Exponentlal Decay Constant.(Coherence Function Model)

4 
at any two polnts on the two members decreases. The shorter the wavelength. the less the correlation length and consequently $\bar{R}_{s}(\bar{k})$ decreases for shorter havelengths (higher values of $\bar{k}$ ).

For the same 2 members. Flg. 6.19 shows the varlation in $R_{f}(\bar{k})$ with $\bar{k}$ for 3 different values of $c$. The reduction factor shows the same trends mentloned above. In Flg. 6.20. $R_{z}(\bar{k})$ is plotted for the case of $n$ and s are ditterent nodes and are some distance apart. Besldes the above mentloned trends, one tan notlce the substantial decrease in $\mathrm{R}_{I}(\bar{k})$ In thls case due to the separating distance.

The wave force spectrum on two vertlcal members separated by a distance $\Delta x$ is evaluated for different $\Delta x / \lambda$ ratlos. Flg. 6.21 shows the varlation in the redi part of $S_{f_{z} p_{I}}(\bar{k})$ for the coherence functlon model for 3 different values of $c$. The varlation with $\Delta x / \lambda$ is perlodlc with a spatlal perlod of $\Delta x=\lambda$ whlch renects the perlodic nature of the unldirectlonal waves. However, the lack of spatlal correlation, represented by the coherence functlon model, leads to the attenuation of the spectral amplltudes as $\Delta r / \lambda$ Increases. This atlenuation is faster for larger values of $c$. A shift in the peak of the spectrum is also notlced. 1.e. the peaks do not occur exactly at $\Delta I / \lambda=0,1,2$. This is attributed to the particlpation of both the velocity and acceleration of water particle (which are not in phase) to the total nuld load.

Fig. 6.22 shows the varlation in the real part of $S_{f_{3}}(\bar{\kappa})$ for the directional spectrum model with $\Delta x / \lambda$ calculated for 3 different values of $\bar{a}$." It can be btlced that some attenuation ocçurs for the spectrat amplitudes $\Delta x / \lambda$ Increases. The varlation of the real parts and absolute values of $S_{J_{I}{ }_{I}}(\bar{\alpha})$. evaluated for the unldirectlonal as well as the directlonal spectrum model and the coherence functlon model is shown In Fleg. 6.23 and 6.24 , respectlvely. It can be 





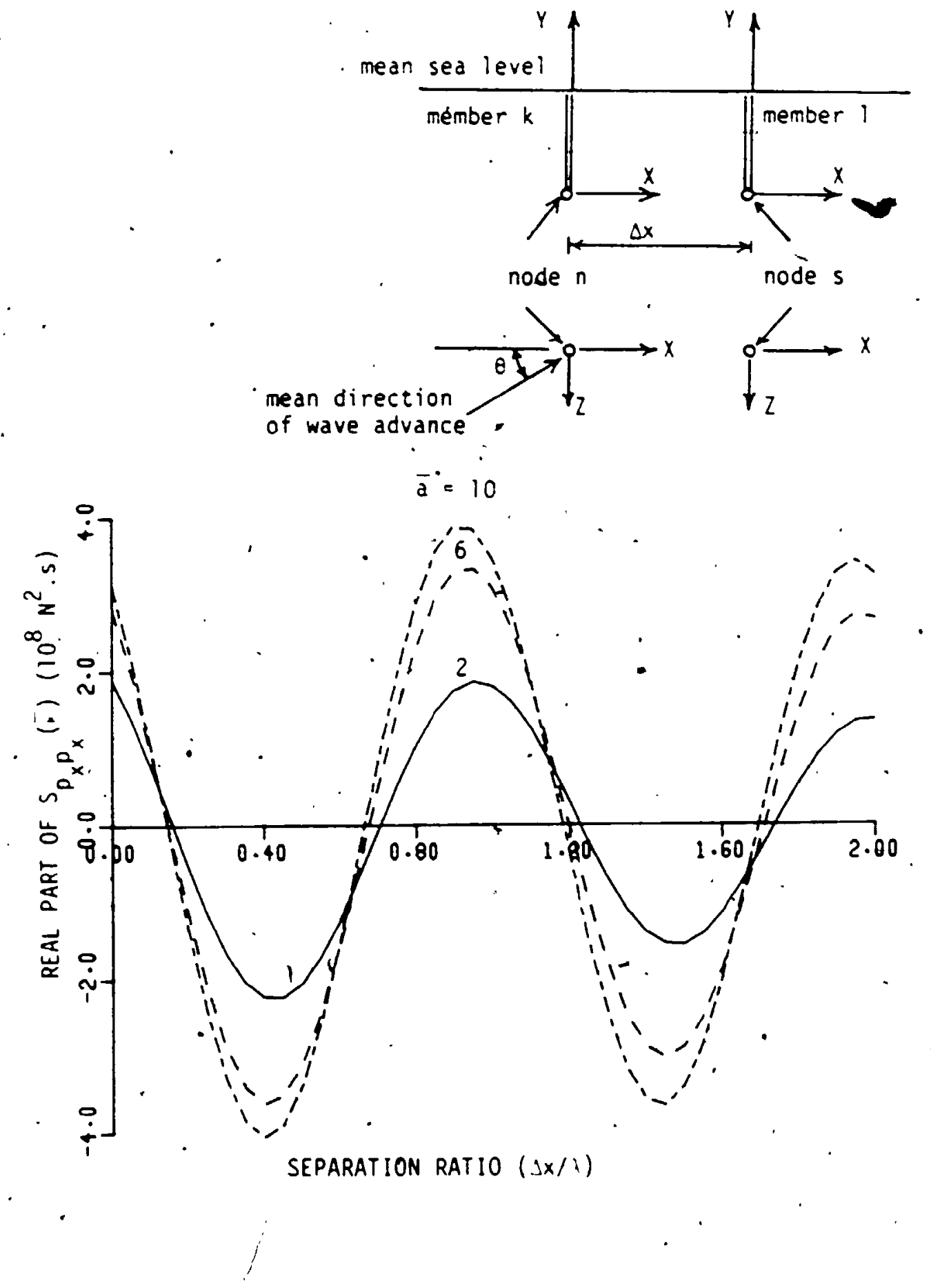

Figure 6-22: Varlation In the Real Part of Along Wave Force Spectrum with Separation to Wave Length Ratlo (Directlonal Spectrum Model)

F. 
notlced that no sttenuation of tbe spectral amplitudes occur for the fully correlated model. From Figs. 6.21 to 8.24 . It can be seen that the attenuation of the spectral ampitudes evaluated using the coherence function model is almost exponentlal and is sensltive to the value of the constame. On the other hand. the attenuation obtalned using the directlonal spectrum model is almost nnear. The parameters of both models can be chosen such that a simllar attenuation is obtalned by both models in a certaln range of $J x / \lambda$.

\subsubsection{Effect of Lumping the Members at the Nodes}

The redution factor $R_{z_{0}}$. defined by Eg. 6.81 . Is plotted versus, the exponentlad decay costant $c$ in Fig. 6.25 for 3 difrerent values of $\bar{k}$. Since the member is extendini vertically above the node, the ratlo $R_{z}$ is expected to be less than one for well correlated waves (large wavelengths and smaller.values of c). However. $R_{z_{0}}$ may exceed unlty for hlgher values of $c$ gince the-approximate veloclty values are not reduced by the lack of spatlal correlation when the two members colnclde. $R_{z_{0}}$ varles llnearly with the constant $c$ and has higher values, for longer wave lengths. Shown In Fig. 6.26 is the varlailon in $R_{I_{0}}$ with $\bar{k}$ for 3 different values of $c$ at $\bar{\theta}=0^{\circ} . . R_{s_{0}}$ decreases moderately wilth $\dot{k}$ for longer wave lengths $(\bar{k}, 0)$ and then drops'sharply with $\bar{k}$ at higher frequencles due to the exponentlal veloclty pronle at thesè frequencles.

Flg. 0.27 shows the varlation In $R_{z_{0}}$ calculated for the coherence function model $(c=5)$ as well as the duectional spectrum model (for any value of $\bar{a}$ ), with $\bar{k}$. Boith models give comparable results for $R_{x_{0}}$ in the range of $\bar{k}=0.1$ to 1.0 . 
174

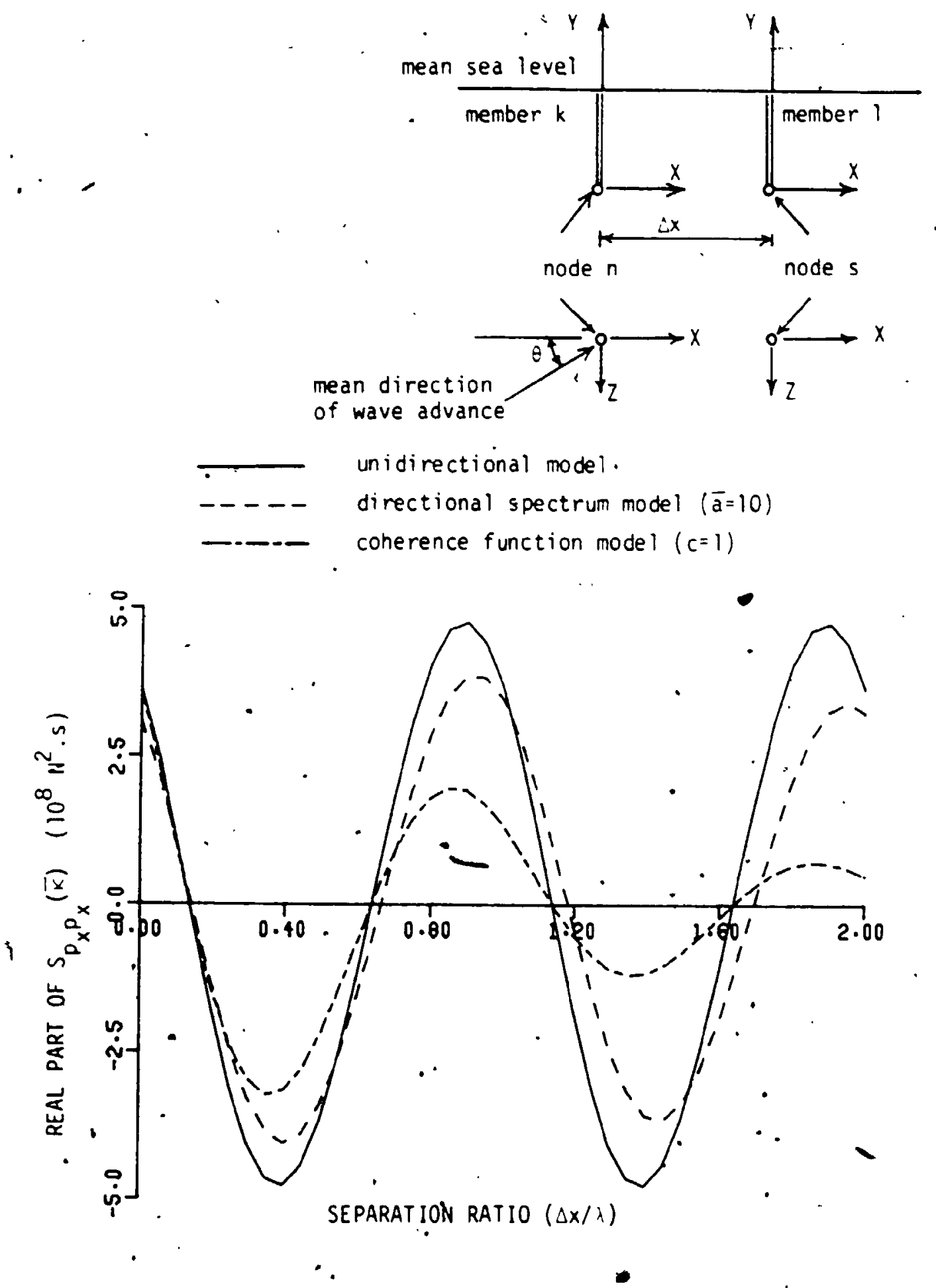

- Figure 6-28: Variation In the Real Part of Along Wave Force Spectrum with Separation to Wave Length Ratio (Comparison Between Three Models)

1 

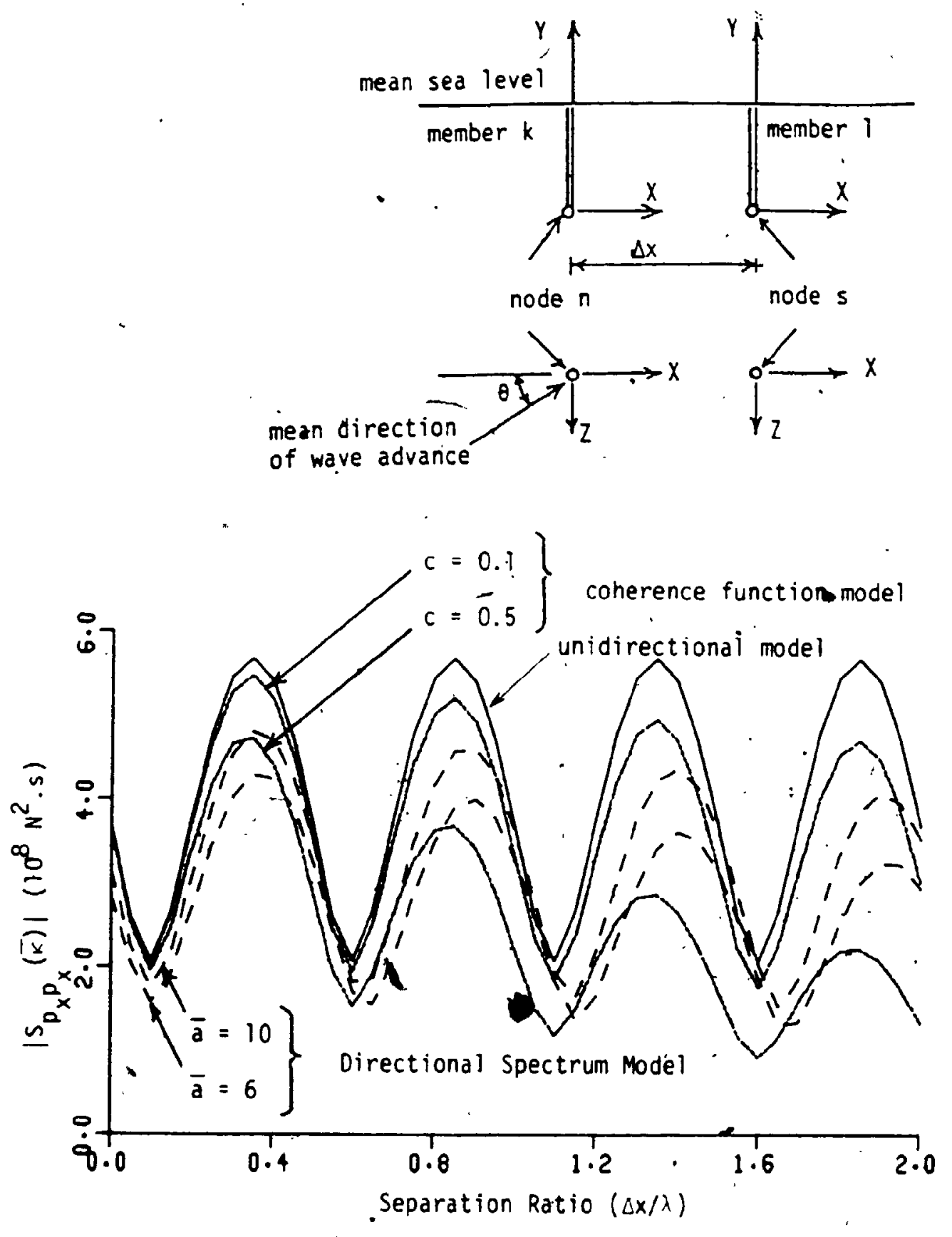

Figure 6-24: Varlation In the Absolute Value of Along Wave Force Spectrum with Separation to Wave Length Ratlo (Comparlson Between Three Models) 

184

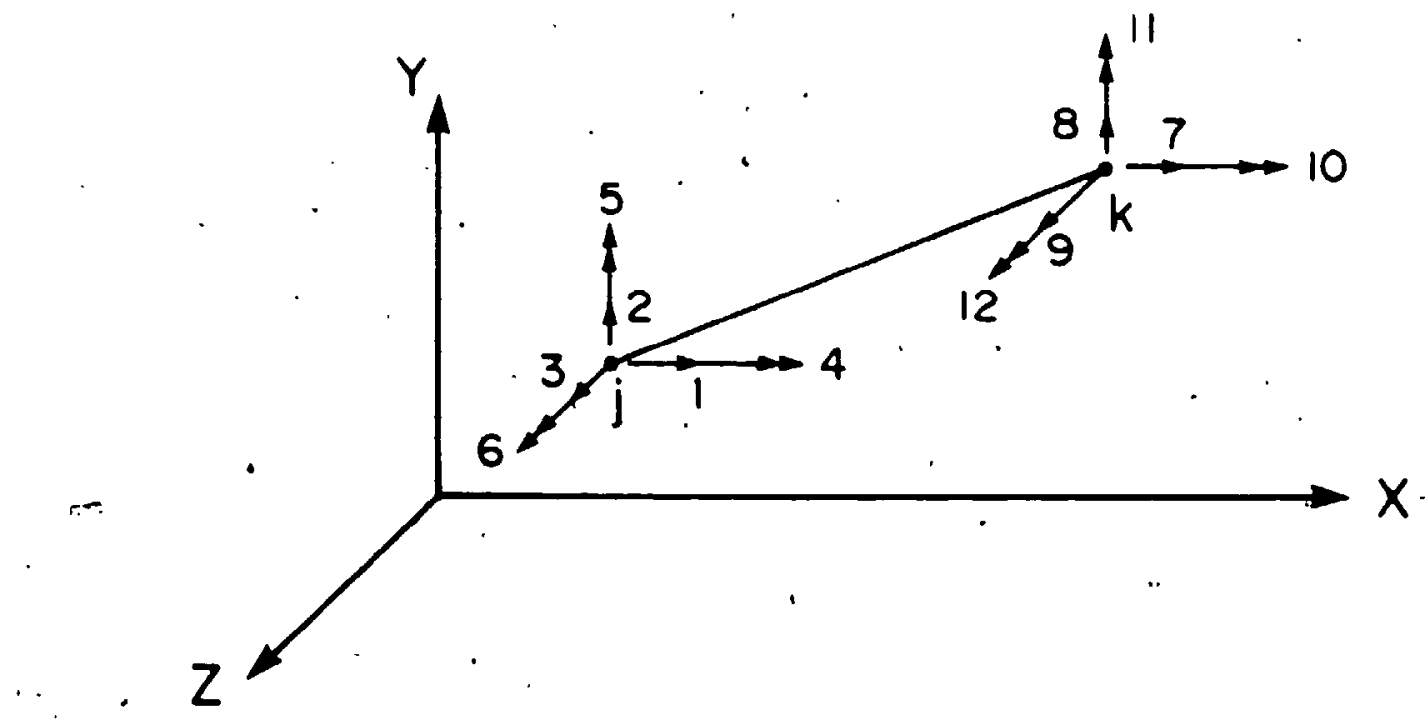

Figure 7-2: Cartesian Coordinate System 
177

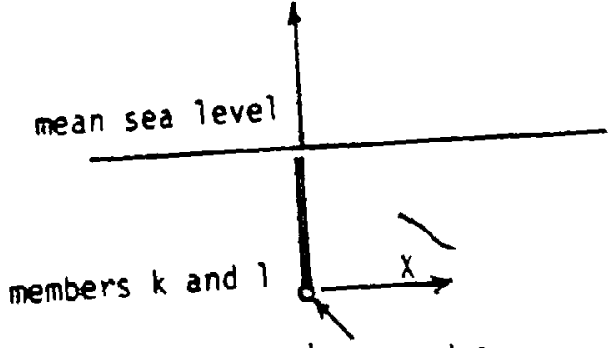

mean direction of

nodes $n$ and $s$ wave advance

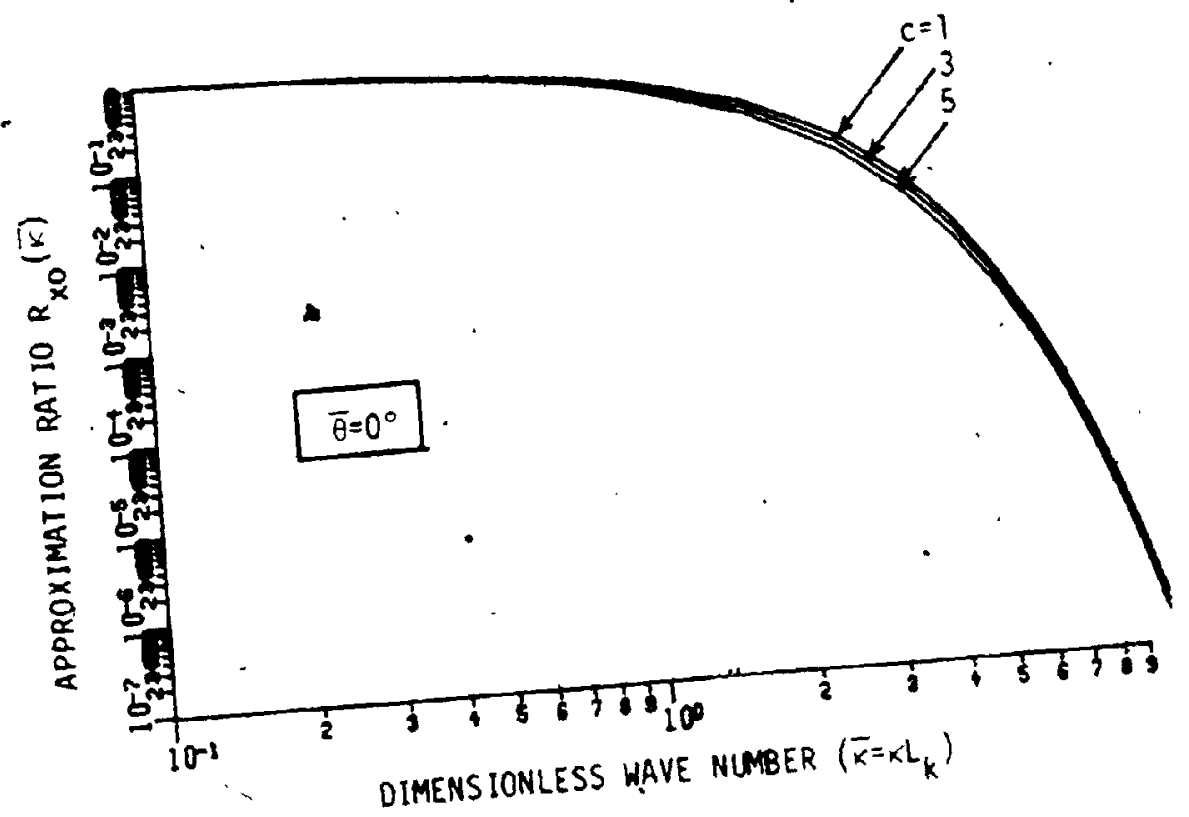

Figure 6-26: Variation in the Approximation Ratio $R_{z_{0}}$ with Dimensionless Wavenumber (Coherence Function Model) 



\subsection{Conclusions}

Spectra of wave forces on members of ortshore structures are derlied conslderlng the cross spectra of water particle kinematles to vary with position along the members. The standard directional spectrum is nrst utllized to represent the cross spectra of water partlcie kinematles and the resulting expresstons for the spectra of wave forces are hence termed the directional spectrum model. An alternatlve representation of the cross spectra of water particle kinematics. based on a coherence function, is suggested and the resulting expressions are termed the coherence function model. Three Important quantitles are evaluated using both models and the results are compared for vertleal members whlch are assoclated wilh the largest dlameters. A parametric study is carrled out to examine the variation of each of these quantitles ulth the Independent parameters and the following conclustons emerge:

1. The across wave force component evaluated from the directional I spectrum model is generally small. typlcally about $B C_{c}$ of the along, wave force component. The coherence function model. fails ' 10 ' represent this component.

2. When the mean direction of wave advance makes an angle in the range of $15^{\circ}$ to $75^{\circ}$ with the $X$ axis, where both force components are important. both models give close values for the ratio between the two horlzontal force components.

3. The error introduced in the results of both models by assuming a constant cross spectrum of water particle velocty along the members increases with the increase in dimenstonless frequency $\bar{F}$. K is mainly due to the rapld decay of the veloclty pronle with depth at high dimenslonless frequencles. This error tends to be cancelled when. evaluating the wave forces for the whole structure as some irlbutary" lengths are above the nodes and some are below the nodes.

4. The values of the exponentlal decay conshon may be establlshed io glve a reduction In the along wave forces comparable to that due 10 directlonal spread at a specinc value of the directional spread consiant.

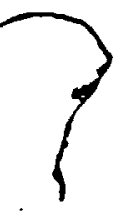




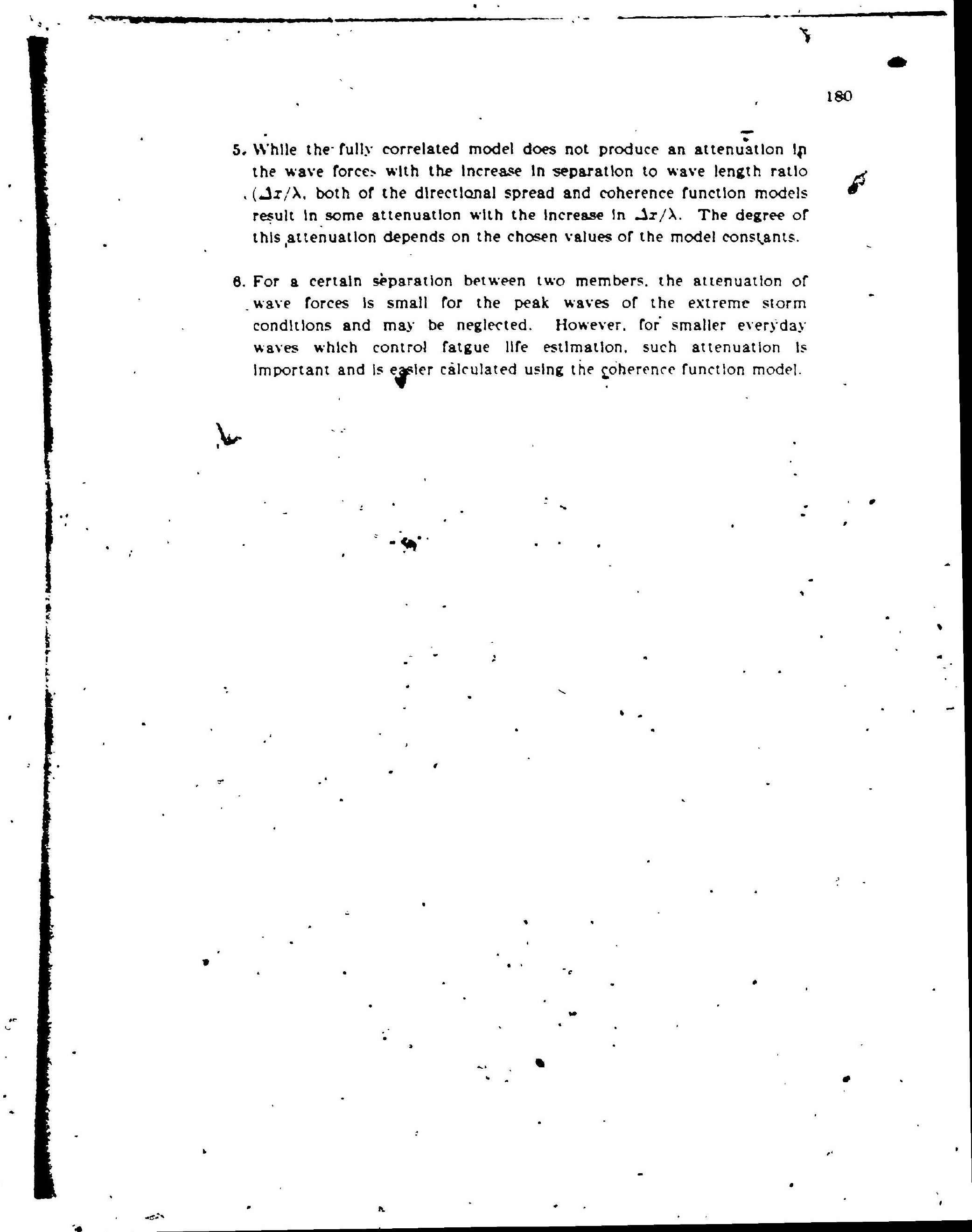




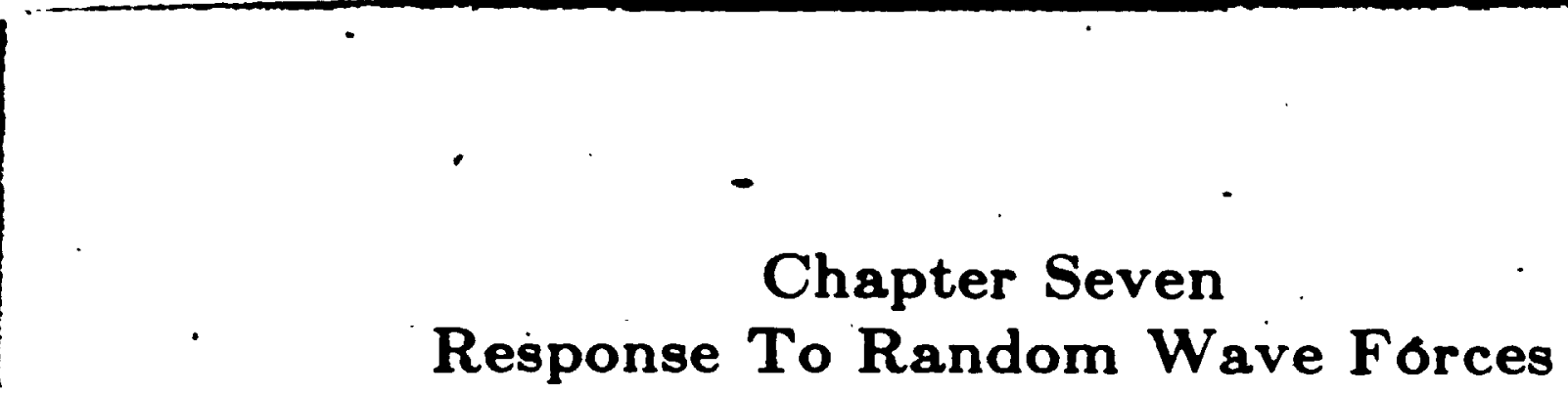

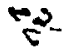

\subsection{Introduction}

Accurate prediction and measurement of natural frequencles. damplng ratlos and response amplitudes is of partlcular importance for ofrshore structures. Monltoring of natural frequencles of the structure allows the detectlon of damage of the structure and foundation that might. have occured. However, to be able to use the monitoring data in a meaningful sense, all the parameters affecting the natural frequencles should be known and their Infuence well understood. Mlodal damplne ratlos are also Important since they control the dynamlc magnincation at the natural frequencles.

Prediction of the above mentloned quantltles depends on the accuracy of the Input parameters, on the matbematical models used to represent the system and the method employed to solve the governing equations. Due to the large uncertalatles assoclated with many of the Input parameters (such as dynamle soll propertles. drag and Inertla coemclents and descriptlon of the sea states) more sophlstlcated models do not guarantee better results.

- In this chapter, the governing equations or motion are formulated and the solution procedure is described. The superstructure is ideallzed as a space frame. masses are lumped at the structural nodes and structural damplng is modeled by equlvalent viscous damplng. Niatural frequencles. damplng ratios and mode shapes are obtalned by solving the equations of free vibration using the complex elgen value analysls. Spectra of the structural response to wave fotces are evaluated using the modal superposition method. The response evaluation is carrled out in an Iteratlve procedure due to the dependence of the hydrodynamic damplng on the structural displacements. 


\subsection{Structural Idealization}

\subsubsection{General}

Structural members of an oftshore tower behave linearly within a certatr deformation range beyond whlch they behave nonlinearly. Popor et al. 164 examined the Inelastlc behavlour of nxed oftshore towers under severe earthquakr excitation and concluded that such an analysis is impartant $10^{\circ}$ avold unnecessarlly high safety factors. Within the linear elastic range. the strustural model has the least uncertalntles and using space frame elements, assemblage of ine stiffness matrlx is stralghtforward.

For shallow water structures. the number of Jolnts is small and the model nodes may colncide with the structural Jolnts Some simplincation can be brought about for large deep water structures by considering an equivalent beam - model where each vertlcal segment of the structure Is replaced by an equivalent beam element. For analysls purposes, such simplinjing Ideallzations have been used [165.166). Berge et al. [143) assumed a Higld dlaphragm at each horizontal level. thus $11 \mathrm{~m} l t \mathrm{ng}$ the number of nodes to one at each level. Penzlen et al. [167,168] used an equivalent one dimensional model and assigned stimness coemclents that are typlcal of real deslgn values. However, these models might fall to account for soll-structure Interaction In a reallstlc way. In paruçular, one dimeñslonal models require improvements in order to account, for plle-soll-plle Interaction of nexible foundations.

In this study, the structure is Ideajfed as a sipace frame as shown In Fig. 7.1. Each node has slix degrees of freedom, 3 tranglatlons and 3 rotations. The global cartesian axes are $X, Y$ and $Z$ with the positlve directlons shown in Fig. 7.2. 
183 


mass matrlx is readlly condensed by omltting the zero rous and columns corresponding to the rotational d.or and the stimness matrla is condensed using slatlc condensation.

Structural damplng (materlal damplng: is hysteretle in nature and can be Incorporated in the analysls using the complex struciura! silmness matrlx $h_{*} \cdot$ • denned by

$$
\left.K_{*}^{*}=h^{\prime}: 1+23\right)
$$

where $K_{\text {, }}$, Is the real condensed stiffness matrlx of the superstructure and 3 is the materlal damping ratlo. The Imaginary part of Eq. 7.1 represents the materla! damplng. In this study. structural damping is expressed as equivalent viscous damplng and the damplng matrix of the superstructure $C$. is glven by

$$
\left.i C_{A}\right)=\frac{23 K_{a}}{\dot{a}}
$$

\subsubsection{Symmetry}

Signincant reduction in the storage tequlrements and computation costs cart be achleved In the analysls of structures which possess a symmetric connguration with regard to one or more vertlcal planes. In these cases, only part of the structure is assembled. For example. If the structure is symmetric with regard to 2 vertical planes. only one quarter is assembled and 4 cases of this model yleld all the vibration modes. Two cases for the structure vibrating elther symmetrically or antlsymmetrically with respect to both planes and two cases for the structure vibrating symmetrlcally with regard to one plane and antlsymmetrically with regard to the other $\{174)$.

For the superstructure thls is achleved by Imposing the approprlate boundary conditions on the d.o.f falling on planes of symmetry or antlsymmetry. Symmetry is taken into account for the foundation stiffness matrlx by rewrliting the foundation Mexlbllty equation. Eq. 5.17, after equating the appropriato 
degrees of freedom according to the vibration mode under consideration. When one of the plles falls on one of the planes of symmetry. Its rigldlty ls halved slnce only one half of It is consldered with the assembled part of the structure in a nexlblilty formulatlon this corresponds to doubling its nexlbillty.

\subsection{Governing Equations of Motion}

With the foundation model denned in Chapter 5. the hydrodynamic forces formulated in Chapter $b$ and the structural Idealization Illustrated in Section $\mathbf{7 . 2}$. the equations of motion of an offshore tower subjected to wave forces are written as

$$
\left[M_{e}\right]\{\ddot{u}\}+\{\mathbf{C}\}\{\dot{u}\}+\{K i\{u\}=\{M(t)\}
$$

In Eq. $\mathbf{z . 3},|K| ;$ is the sum of the stiffness matrlces of the structure $\left.\mid K_{g}\right\}$ and the foundation $\left[K_{b}\right],\left[\bar{C} \mid\right.$ is the sum or the damplng matrices of the structure $\left[C_{s}\right.$ : and the foundation $\left|C_{b}\right|$ and $\left|M_{s}\right|$ is the structural lumped mass matrix. $\{u\} .\{\dot{u}\}$ and $\{\ddot{u}\}$ are the vectors of structural displacements, veloclties and accelerations, respectively. Finaliy, the vector $\{H(t)\}$ is the vector of wave forces whose Indivldual elements are defined by Eq. 6.49. I.e.

$$
\begin{aligned}
& W_{2}(t)=\sum_{k=1}^{N_{n}} \Gamma_{k} \int_{0}^{L_{k}}\left\{\rho \pi \frac{d_{k}^{2}}{4} C_{, \lambda}\left(S_{k}\right) \ddot{i}\left(S_{k}, t\right)\right. \\
& -\rho \pi \frac{d_{k}^{2}}{A}\left(C_{A r}\left(S_{k}\right)-1\right) \ddot{u}\left(S_{k} \cdot t\right) \\
& \left.+\frac{1}{2} \rho d_{k} \dot{C}_{D}\left(S_{k}\right) \mid i\left\langle S_{k}, t\right)-\dot{u}\left(S_{k}, t\right) i\left(i \gamma S_{k}, t\right)-\dot{u}\left(S_{k}, t\right)^{\prime}\right\} d \dot{S}_{k}
\end{aligned}
$$

In Eq. 7.4, $\rho$ is the water density, $d_{k}, L_{k}$ and $\delta_{k}$ are the diameter . tributary length and element coordinate of member $k$. respectlvely. and $\nu_{n}$ is the number of members altached to Jolnt $n$ at whlch d.o.f. $i$ is statloned. $C_{11}$ and $C_{D}$ are the Inertia and drag coefnclents which may vary with depeh but in this study they are assumed to be constant with the respectlve values of 1.4 and 2 . The projected area factor $\Gamma_{k}$ is given by Eq. 6.50. 
The drag component of the tolal wave forces In Eq. 7.4 is nonlinear and has to be llnearlzed for the spectraj analysls to be possible. In inls study. the llnearlzed drag force is obtalned using the equilialent linearlzation iechnlque -discussed in Section 6.2. One method of solving. Eq. 7.3 in lts nonllnear form ts the numertcal Integration of the equations of motion in the tlme domain. This has been altempted by Godeau and Deleull $175:$. however. In addltion to the high: computational costs involved, there is some difnculty assoclated with interpreting the resulting response ilme historles.

Taylor and Rajagopalan i158; used a random vibration approach and a perturbation technique to examine the effects of the nonlinear drag term on the response spectra. The same authors utllized a narrow band approximation of the response logether with the Fokker-Plank equation to obtain estlmates of the effective hydrodynamic damplng and probabllity densltles of the response quantitles [177]. Due to nonlinearlty. subharmonlc resonances occur at frequencles three tlmes the frequency of the luading function. Most nxed offshore towers have thelr fundamental frequencles close to these secondary peaks in the force spectra whlch might lead to an Increase in the resonant response. This is partlcularly important for fatlgue life estimation. They also concluded that the hydrodynamlc damplng evaluated from a llnearlze analysls ls clóse to that evaluated considering the higher order approximatlons.

When the drag force is linearlzed using Eq. 6.5, the llnearlzed nodal load $W_{i}(t)$ ls glven by Eq. 6.52 and by transferlng the added mass and hydrodynamlc damplng to the left hand slde of the equations of motion. Eq. 7.3 is rewrltten as

$$
[K]\{u\}+|C|\{\dot{u}\}+[M]\{\ddot{u}\}=\{P(\ell)\}
$$

where $\left[K^{\prime}\right]$ is given by

$$
\left.\{K\}=\left[K_{s}\right\}+\mid K_{b}\right]
$$

and the foundation stiffness matrix is glven by Eq. 5.16. The total damplng matrix $|C|$ is 


$$
C:=i C_{s} i+i C_{b} j+C_{11}
$$

in whith ine structural damplng matrlx $C_{2}:$ is glven by Eq. 7.2 . the foundation dampingtmatrlx $C_{b}$. is the equivalent viscous damping of the roundation system. defined as

$$
\left.\bar{C}_{b}=\operatorname{Im}\left\{i F_{b}\right\}^{-1}\right\} /
$$

where the complex foundation flexibllity matrix $\left|F_{b}\right|$ is given by Eq. 5.17 and the hydrodynamlc dampling matrix $\left\{C_{n}\right\}$ is a diagonal matrix with elements

$$
\left(C_{H}\right)_{n}=\sum_{k=1}^{V_{n}} \frac{1}{2} \rho C_{D} d_{k} \sqrt{8 / \pi} \sigma_{i_{i}} \Gamma_{k} L_{k}
$$

In Eq. 7.8. $\sigma_{r_{i}}$ is the standard devlation of the relative veloclty $r_{i}$ between the structure and the water particles at the position and direction of d.o.f. $i . \mid M]$ is the tatal mass matrix whlch is the sum of the structural dlagonal mass matrix and the added mass matrix which is also diagonal, l.e.

$$
\left(M_{a}\right)_{3 i}=\sum_{k=1}^{N_{n}} \rho\left(C_{M}-1\right) \pi \frac{d_{k}^{2}}{4} \Gamma_{k} L_{k}
$$

In Eq. 7.5, the stiffness and damping matrices are frequency dependent as they Include the foundation propertles. One way of solving Eq. 7.5 is the frequency resporise method. e.8. [64]. In this method, the time dependent forrcing vector is Pourler transformed Into a set of discrete harmonlc components. The response to each of these components. which is also harmonlc. Is obtalned by solving the resulting set of llnear slmultaneous algebralc equations glving the frequency responses of different degrees of freedom. Time historles of the responses can be obtalned as the Inverse Fourler transforms of the frequency response amplitudes of each degree of freedom and the power spectral density of the response is obtalned from the gtandard relationshlp with the Fourler transform. The frequency response method, which has been employed by Penzlen 
[67] and by Angelldes [168), Is sultable for systems with frequency dependent propertles. However, when the number of degrees of freedom is large. this method becomes computatlonally expenslve and the modal superpositon method Is prefered speclally when the response is dominated by the nrst fen modes.

Solution of the equations of free vibration is the nrst step in modal analysls as It provides the natural frequencles. mode shapes and the modal damping ratlos. However, due to the non proportlonallty of damping. classical normal modes do not uncouple the damping matrix. This dirnculty has been surpased by Malhotra and Penzlen [133) who assumed a dlagonat damplng matrli (10 uncouple the modes) whose terms are evaluated by optlmizing the resulung error using the least square minimization technlque. Foster [144] used the nonclassical complex elgen valued modal superposition to uncouple the equations of motion. In thls study, the modal superposition method is used and the complex elgen" value approach is used to solve the equations of free vibration. Foundation stirfness and damplng malitces are evaluated at the nrst natural frequency whlch Is obtalned by Iteration starting with undamped system and classical analysis.

\subsection{Free Vibration Analysis}

Equations of motion for the free vibration are obtalned from Eq. 7.5 by setting $\{P(t)\}$ to zero, l.e.

$$
\mid K]\{u\}+|C|\{\dot{u}\}+|M|\{\ddot{u}\}=\{0\}
$$

- The complementary function of the reduced equation; Eq. 7.11. Is sought in the form

$$
\{u\}=\{\phi\} e^{\lambda t}
$$

where $\{\phi\}$ is a vector of constants and $\lambda$ sbould satisfy the characteristic - equation obtalned on substituting by Eq. 7.12 Into Eq. 7.11. 1.e.

$$
\left.\left(\lambda^{2} \mid M\right]+\lambda[C]+|K|\right)\{\phi\}=\{0\}
$$

Eq. 7.13 is a set of algebralc equations of order $\Lambda$ in $\lambda^{2}$ whose solution in this 
Torm is tedlous and not amenable to the algorithms developed for solving the standard and the geperallzed elgen value problems.

A method has been suggested whereby a set of $\lambda$ second order linear differentlal equations (L.D.E.) is transformed into a set of 2.1 nrst order L.D.F. $[178,179]$

$$
[A[\{\dot{q}\}+[B]\{q\}=\{0\}
$$

In which

$$
\{q\}=\left\{\begin{array}{l}
\{i\} \\
\{u\}
\end{array}\right\} \text {. }
$$

and the matrices $[A]$ and $[B]$ are given by

$$
[A]=\left[\begin{array}{ll}
|0| & \mid M_{i} \\
\mid M Y_{i} & \mid C_{j}
\end{array}\right]
$$

and

$$
\left\{i=\left[\begin{array}{ll}
-\{. M\} & \mid 0\} \\
\mid 0\} & \left\{K^{\prime}\right\}
\end{array}\right]\right.
$$

The solution to Eq. 7.14 is sought in the form

$$
\{q\}=\{\Phi\} e^{\mu t}
$$

Substltuting Eq. 7.18 in Eq. 7.14 ylelds

$$
\mu|A|\{\Phi\}+\{B \mid\{\Phi\}=\{0\}
$$

which is the generalized elgen value problem.

Solution or Eq. 7.19 ylelds $N$ palrs of complex conjugate elgen values and $N$ palrs of complex confugate elgen vectors. The complex elgen values can be expressed in the form

$$
(\mu)_{1,2}=-\zeta_{j} \omega_{j}^{\prime} \pm 8 \omega, \sqrt{1-\zeta_{j}^{2}}
$$

from which the modal damplng is easlly extracted [180]. Eq. 7.20 is formally Identical to the solution of the free damped vibration of a Ingte degree of freedom system. From Eq. 7.20. the damped frequency $\omega_{j}^{\prime}$ is glven by 


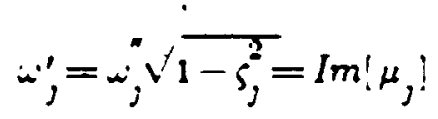

and the $j^{\text {th }}$ modal damplng ratlo is given by

$$
\varsigma_{j}=\frac{-\operatorname{Re}\left[\mu_{j} \mid\right.}{\mid \mu_{j} !}
$$

where Re and Im Indicate the real and imaginary parts, respectlely. This method has been used in soll-structure Interaction problems. e.g. $1181.182 ;$ and is also used in thls study as it establlshes the modal damping ratlos accurately. More detalls on thls method can be found in [181].

\subsection{Response to Wave Forces}

With the natural frequencles, modal damping ratlos and mode shapes evaluated, the solution proceeds by making a coordinate transformation from the kinematlc degrees of freedom to the generalized coordlnates.l.e.

$$
u_{i}(t)=\sum_{j=1}^{N} 0_{i j} \eta_{j}(t)
$$

Where $\phi_{i j}$ is the modal coordinate assoclated with d.o.f. i in mode $J$ and $\eta_{j}(t)$ is the generalized coordlnate of mode $j$. Expressed In matrix notation. Eq. 7.23 becomes

$$
\{u(t)\}=[\Phi \mid\{\eta(t)\}
$$

where $[\Phi]$ is the modal matrix contalning all the mode shapes. If undamped modes are used, In Eq. 7.24. $\{u(t)\}$ is a vector with $N$ elements where $N$ is the total number of unrestrained degrees of freedom. $N^{\prime}$ depends on the applled boundary conditions according to the specinc vibration mode. From the theory of random vibration. the spectral denslty of the response at d.o.f. $2 . S_{u_{i} u_{i}}($ is $)$ is

$$
S_{u_{j} u_{i}}(\omega)=\sum_{j=1}^{N} \sum_{r=1}^{N} \phi_{i j} \phi_{i r} S_{r_{j}, \eta_{r}}(\omega)
$$

where $S_{\eta_{j} \eta_{r}}(\omega)$ is the cross spectrum of the generallzed coordinates $\eta_{j}(t)$ and $\eta_{r}(l)$, and is glven by 


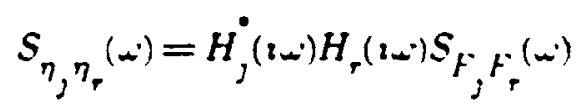

In Eq. 7.26. $H_{J}\left(2 \omega^{\prime}\right)$ and $H_{r}\left(2 \omega^{\prime}\right)$ are the mechanlcal admlttance functions of modes

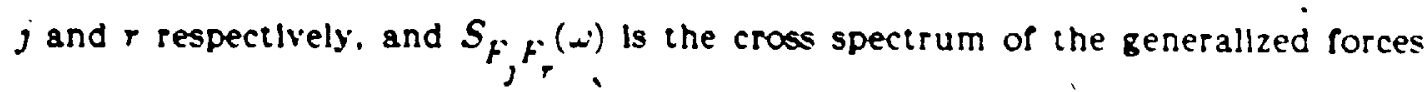
$F_{j}(t)$ and $F_{r}(t)$, respectively.

For a system with discretized nodal loads, such as the one under consideration. the generallzed force in mode J. $F_{j}(t)$. Is

$$
F_{j}(t)=\sum_{i=1}^{i} 0_{i}, P_{i}(t)
$$

Hence, the cross spectrum of the generallzed forces is

$$
s_{F_{j} F_{r}}(\omega)=\sum_{i=1}^{N} \sum_{m=1}^{N} \phi_{i j} \phi_{m r} S_{P_{i} P_{m}}(\omega)
$$

In which $S_{P_{1} P_{m}}(\omega)$ is the cross spectrum of nodal loads $P_{i}(t)$ and $P_{m}(t)$ given by Eq. 6.58. namely

$$
\begin{aligned}
& S_{P_{i} P_{m}}=\sum_{k=1}^{N_{n}} \sum_{l=1}^{N_{b}} \Gamma_{k} \Gamma_{l} \int_{0}^{l_{k}} \int_{0}^{l_{l} l}\left\{\omega^{2} \alpha_{k} \alpha_{l} S_{i_{1} i_{2}}\left(S_{k}, S_{l, \omega}\right)\right. \\
& +\alpha_{k} \beta \sigma_{r_{m}}\left[i \omega S_{i_{1} i_{2}}\left(\dot{S}_{k}, S_{l} \cdot \omega\right)\right]^{\circ} \\
& +2 \omega \beta_{k} \alpha_{l} \sigma_{\dot{r}_{i}} S_{i_{1} i_{2}}\left(S_{k}, S_{l}, \omega\right) \\
& \left.+\beta_{k} \beta_{j} \sigma_{i_{i}} \sigma_{\dot{r}_{m}} S_{\dot{r}_{1} i_{2}}\left\{S_{k}, S_{l}, \omega^{\prime}\right)\right\} d S_{l} d S_{k}
\end{aligned}
$$

In Sectlons 6.5.2.3 and 6.6.2.3. the effects of using a stepwise approximation to the veloclty neld and lumping the areas and volumes of the raembers at the nodes on the eyaluated force spectra were examined. It was shown, that these approximatlons have little effect for longer waves where most of the wave energy lles and that the cancellng efrect tends to reduce the error. Adoptling these approximations is computationally advantageous, therefore they are used in this study. Consequently. Eq. 6.53 reduces to 


$$
P_{i}(t)=\sum_{k=1}^{N_{n}} \Gamma_{k} L_{k}\left\{\alpha_{k} \ddot{L}_{i}\left(S_{k} \cdot t\right)+3_{k} \sigma_{i_{i}} \dot{i}_{i}\left(S_{k} \cdot t\right)\right\}
$$

and Eq. 7.29 reduces to

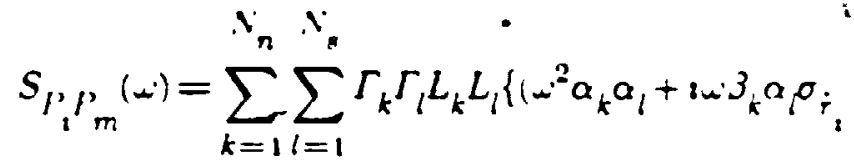

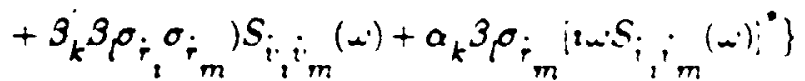

Denote:

$$
\begin{aligned}
A_{k} & =\sum_{k=1}^{Y_{n}} \Gamma_{k} L_{k} a_{k} . \\
B_{k} & =\sum_{k=1}^{N} \Gamma_{k} L_{k} O_{k} \\
\cdots A_{l=1}^{N} & \sum_{l=1}^{N} \Gamma_{l} L_{l} \alpha_{l} \\
B_{l} & =\sum_{l=1}^{N} \Gamma_{l} L_{l} B_{l}
\end{aligned}
$$

After rearranging the terms and substltutih by Eqs. 7.32 to 7.35 . Eq. 7.31 becomes

$$
\begin{aligned}
S_{P_{1} P_{m}}(\omega)= & S_{i_{i} i_{m}}(\omega)\left[\omega^{2} \dot{A}_{k} A_{l}+i \omega \sigma_{r_{l}} B_{k} A_{l}+\sigma_{r_{i} \sigma_{r}} B_{k} B_{l}\right] \\
& +\left[i \omega S_{i_{i} i_{m}}(\omega)\right]^{*} \omega \sigma_{r_{m}} A_{k} B_{l} .
\end{aligned}
$$

All the quantitles requlred to evgtuate the response spectrum. Eq. 7.25. are now deffned except for the stand fyd devlation of the relatlve velocltes. The yarlance of the relative yeloclty is obtalined from its power spectrum, l.e.

$$
\sigma_{i}^{2}=\int_{0}^{\infty} S_{r_{i} r_{i}}(\omega) d \omega
$$

As

$$
\dot{r}_{i}(t)=\dot{v}_{1}(t)-\dot{r}_{1}(t) \because \because:
$$

the power spectral density $S_{i_{i}}(\omega)$ Is expressed as 

foundation modal damplng ratlos $\varsigma_{\rho_{j}}$ and the structural modal damping ratlos ; are evaluated separately in the free vibration analysls. Thls is dope by considering only the pertinent damping matrlx for each case in Fa. 7.7. The structural modal damplng ratlos $S_{s}$ obtalned in thls manner are correct only for the nrst mode. For higher modes, the corrected structural damplng ratios ;, are obtalned from

$\cdot \varsigma_{n j}=\varsigma_{s j} \omega_{1} / \mu_{j}$

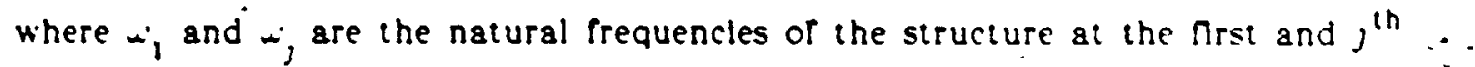
mode, respectlvely. Foundation damplng ratlos $s_{f}$ obtalned in this manner do not need this correction as the variation in stirfness and damping propertles at low frequencles is very mild. However, the response is usually dominated by the nirst mode for real structures.

The response analysis proceeds by specifylng the sea state (for fully developed seas. the sea state is completely speched by the characterlstic wind speed $C$ ) and is performed in an lterative procedure. In the nrst cycle, structural velocltles are assumed to be zero; then. $\sigma_{r_{i}}=\sigma_{i_{i}}$ and the hydrodynamle damping matrlx $\left\{C_{H} \mid\right.$ can be evaluated using Eq. 7.9. A free vibration analysis is carried out to detefm Ine the hydrodynamlc modal damplng ratlos $s_{h}$. This is done by settlng the foundation and structural dampling matrices to zero in Eq. 7.7. Durlng each cycle the system is linear and superposition holds, thus the total modal damplits ratlo $s_{j}$ is the sum of the foundation. structural and hydrodynamic damiplige ratlos. I.e.

$$
s_{j}=s_{s j}+s_{f j}+s_{h j}
$$

Because of the lierative nature of the solut!on and to avold excessive. computatlonal costs, the classlcal mode shapes are used in the evaluation of the response spectra. Eqs. 7.25, 7.27 and 7.45. Thls is a reasonable approximation 'becáuse 'the difference between classical and nonclasslcal modé shapes is 
slgnincant only for systems with high damplng ratlos and for higher modes. Afer the response spectra are evaluated. new values of the varlances of relative velocitles are evaluated and another cycie of lteration is carried out The lieration procedure is terminated when convergence is achleved according to the following criterion

Y

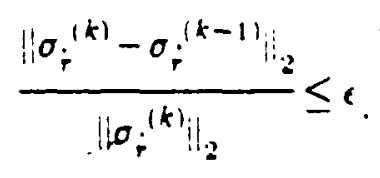

where $f$ is a specined tolerance. $k$ denotes the lteration number and the vector norm lio; is denned by

$$
\text { . }\left\|\sigma_{i}\right\|_{2}=\left(\sum_{i=1}^{i} \sigma_{i}^{2}\right)^{0.3}
$$

The results of thjs analysis are presented In detall in the next chapter for $a^{-}$ Jacket type ofrshore tower. 

199

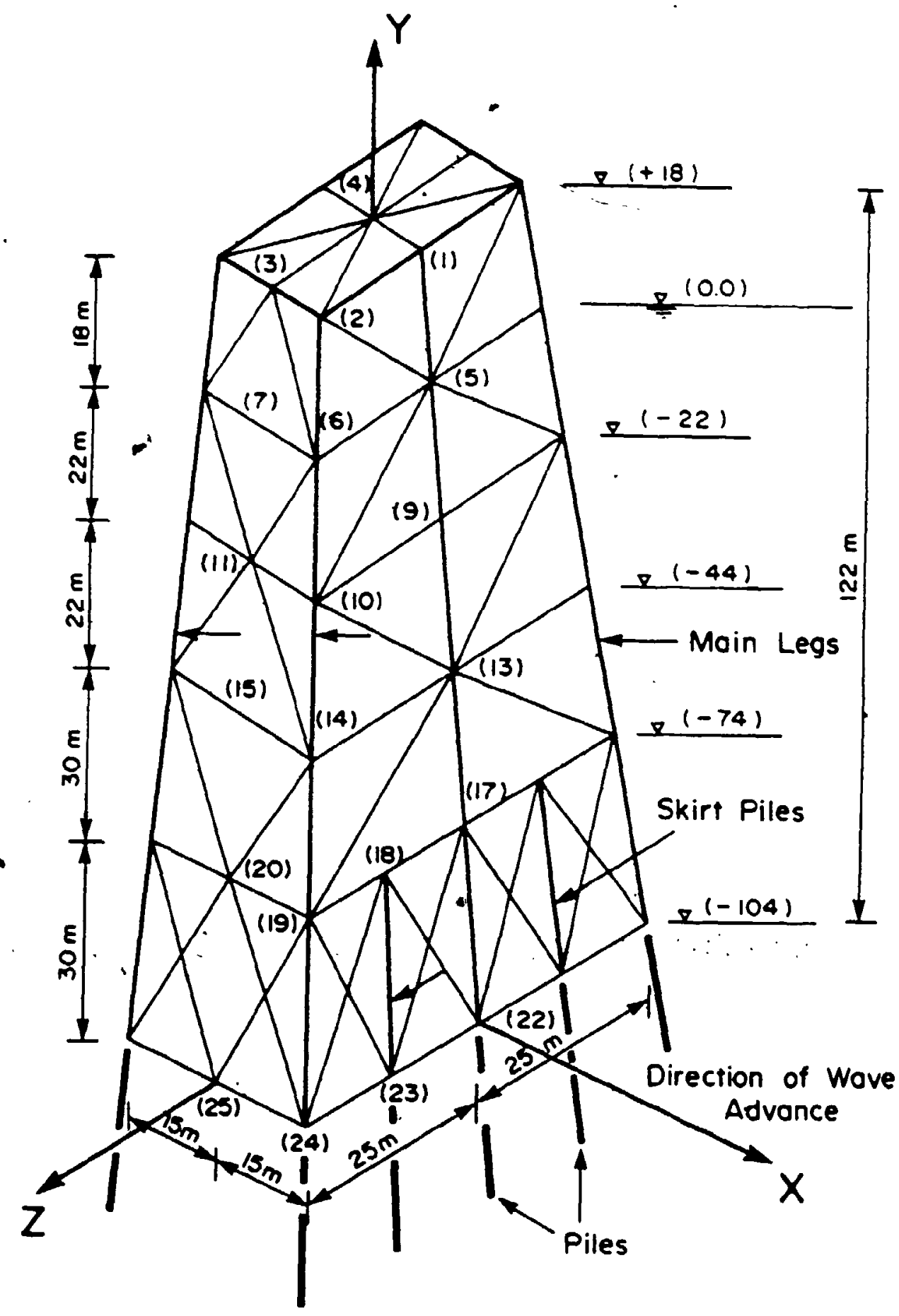

Figure 8-1: Fixed Offshore Tower Used In the Example 

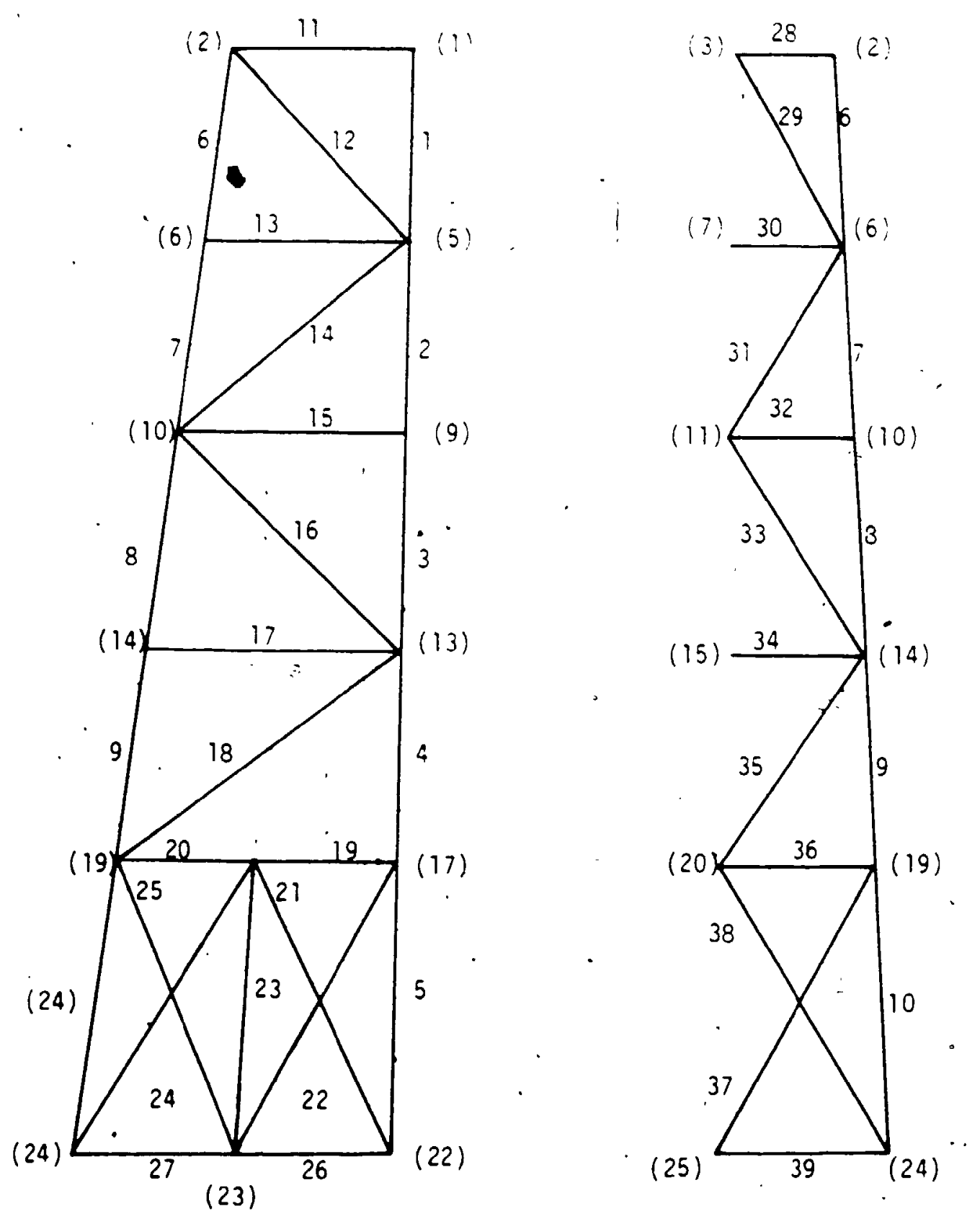

Figure 8-2: Member Numbering of the Tower

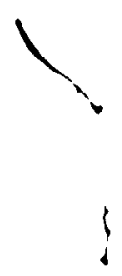



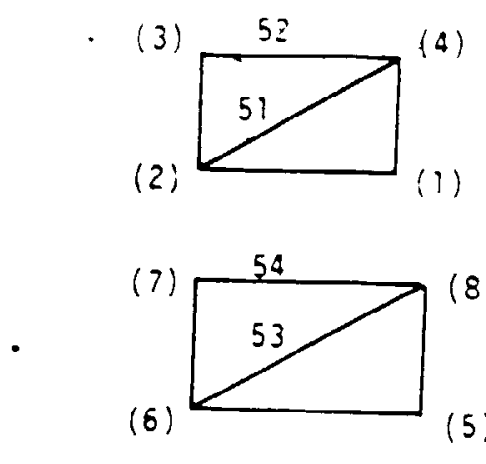

(8)
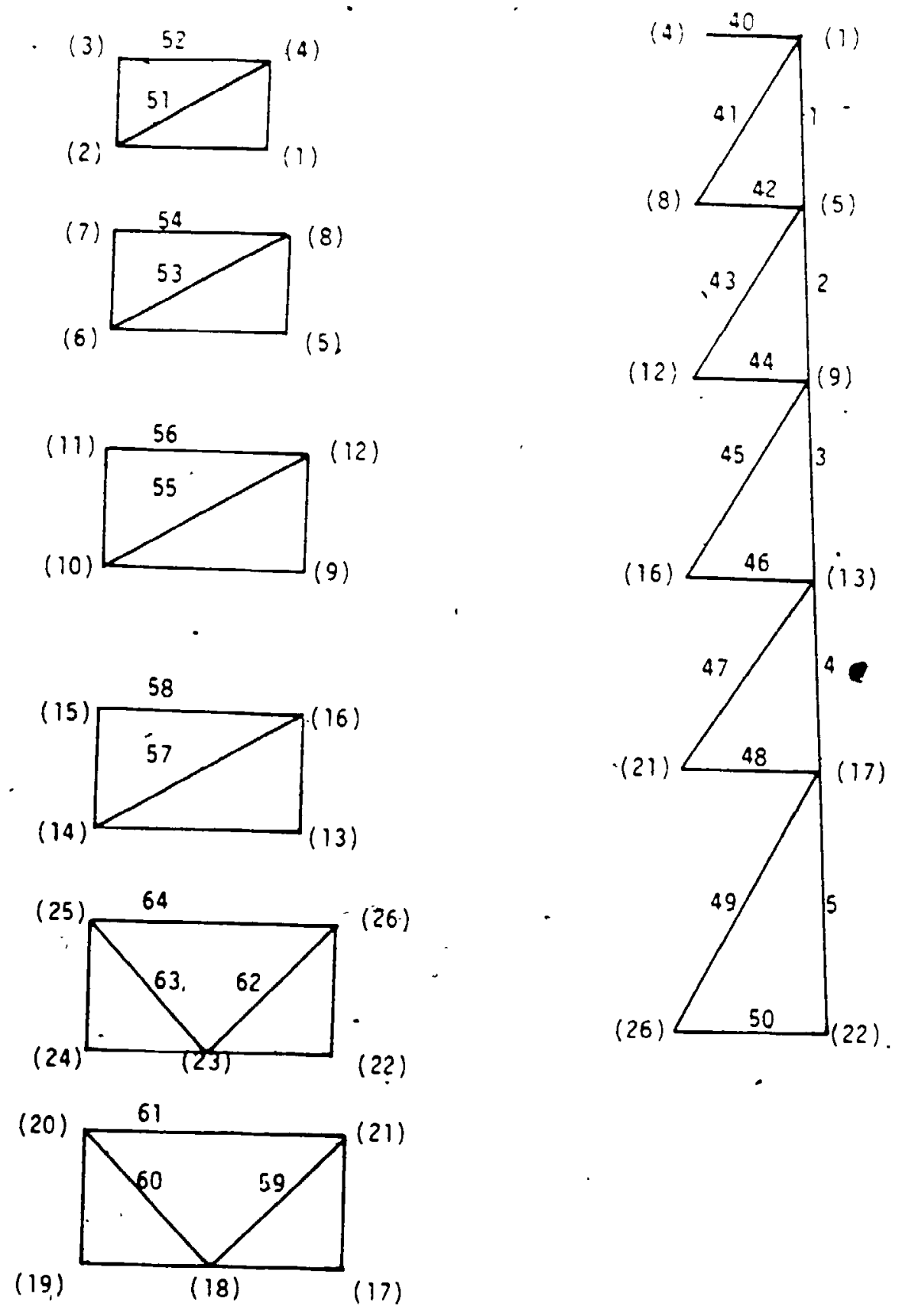

Figure 8-3: Member Numbering of the Tower (Coptlnued) 


\begin{tabular}{|c|c|c|c|}
\hline \multirow{2}{*}{ ( } & Member No. & $\begin{array}{c}\text { Thlckness } \\
\text {; }\end{array}$ & DIameter \\
\hline & $11-28-40-51-52$ & 0.10 & 3.0 \\
\hline \multirow{6}{*}{$c^{\circ}$} & $\begin{array}{l}2-3-4-5-7-8-9-10- \\
23\end{array}$ & 0.04 & $1: 6$ \\
\hline & $1-6$ & 0.04 & $1.6^{-}$ \\
\hline & $\begin{array}{l}16-18-34-49-50-58- \\
61-64\end{array}$ & 0.025 & 1.2 \\
\hline & $\begin{array}{l}12-13-14-15-17-19- \\
20-21-22-24-25-26- \\
27-30-35-37-38-39- \\
44-45-46-48-54-56- \\
59-60-62-63\end{array}$ & 0.02 & 1.0 \\
\hline & $\begin{array}{l}29-31-32-33-36-41- \\
42-43-47-53-55-57\end{array}$ & 0.02 & 0.8 \\
\hline & $p 11 e 8$ & 0.05 & 1.45 \\
\hline
\end{tabular}

Table 8-1: Structural Propertles of the Tower Members 



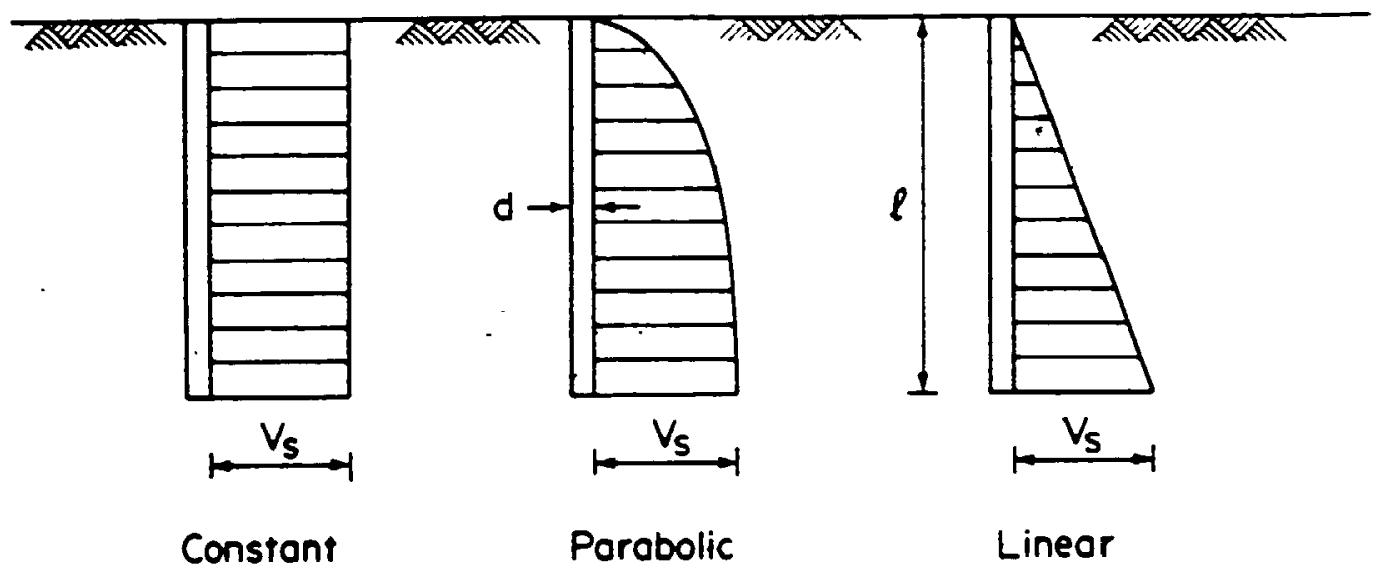

a) Soil profiles with no separation

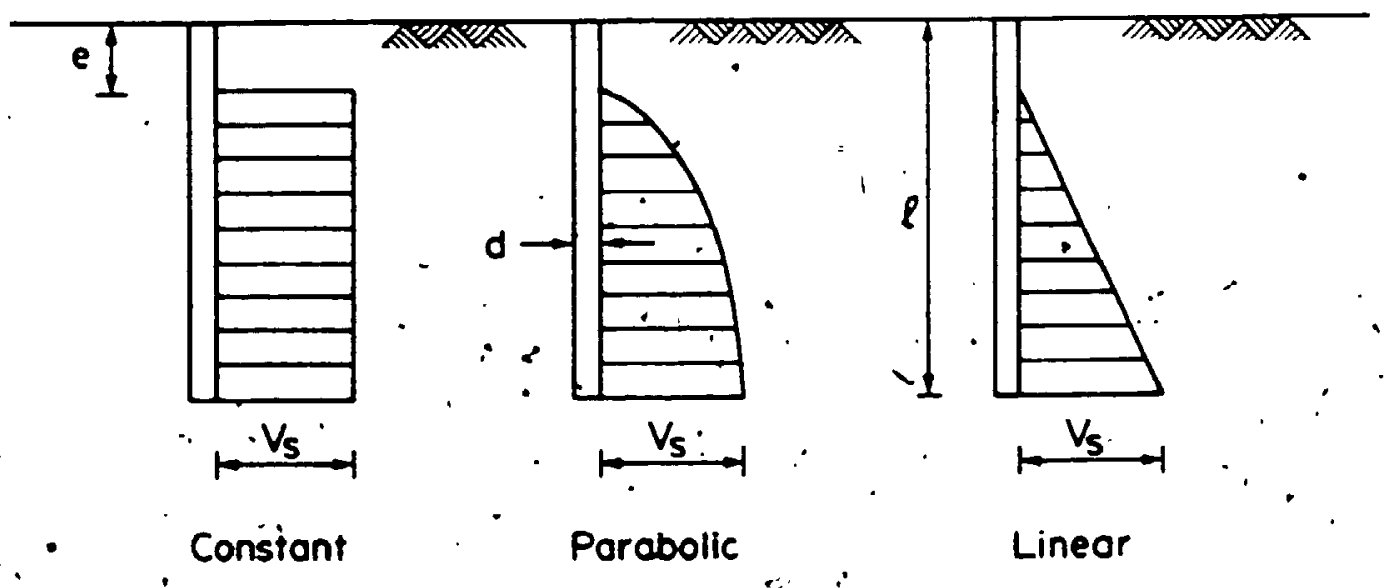

b) Soil Rrofiles with seporation

Figure 8-4: Soll Shear Wave Veloclty Pronles 

208
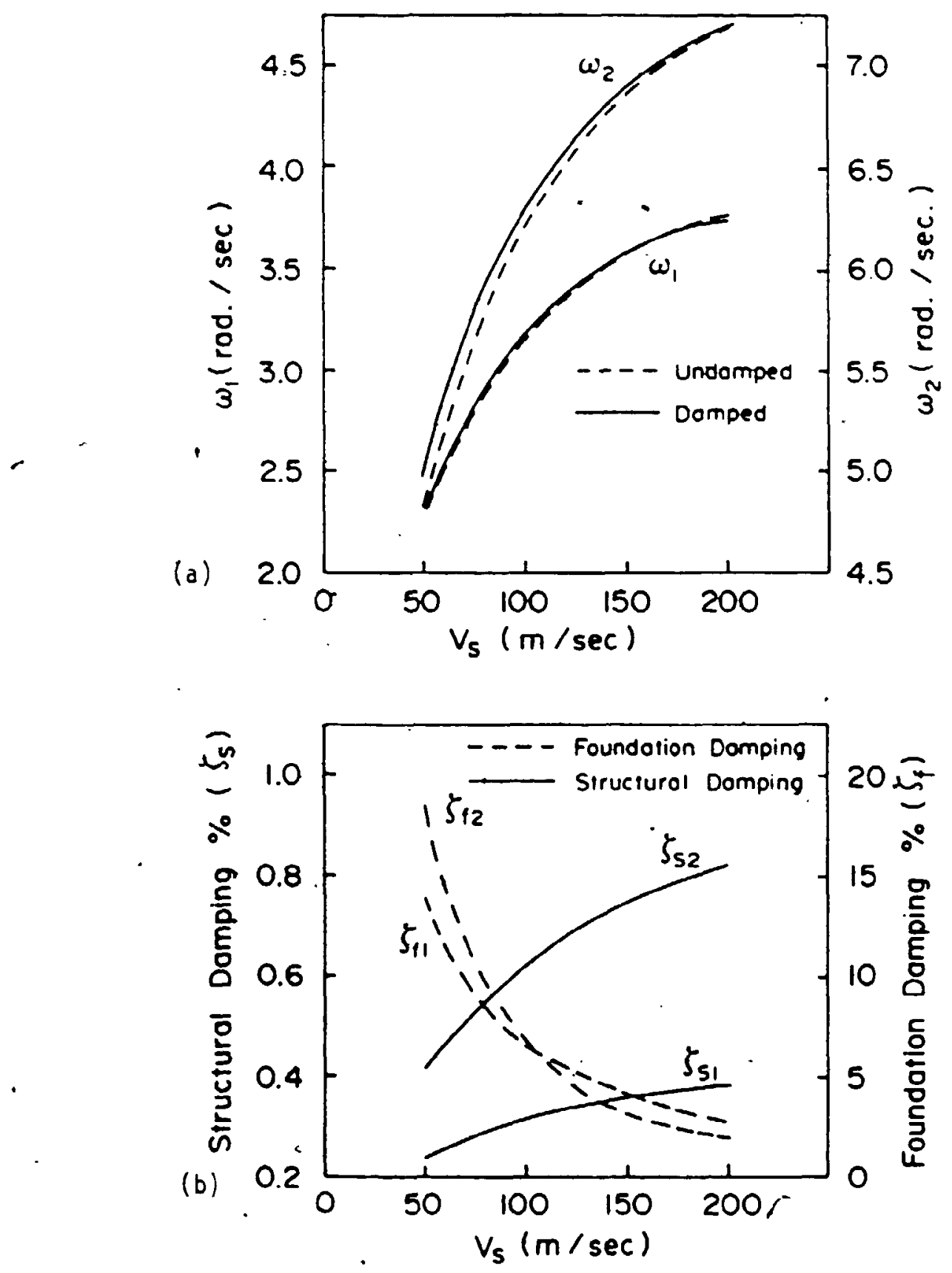

Figure 8-5: Varlation in Vatural Frequencles and Damplng Ratlos of the Tower with Soll Shear Wave Veloclty 
- Increase in foundation damplng rațlos with the increase in solt flexibllity. It can be noticed that the variation in foundation damplng ratlo with shear wave veloclty is greater for the torslonal mode $s_{f 2}$ than it is for the sway mode $s_{f 1}$.

\subsubsection{Effect of Soil Profile}

The decrease in soll shear modulus with the decrease in connning pressure - can be modeled by assuming a soll shear modulus which varles along the length of the plle in a sultable tashlon. Given in Table 8.28 are the nrst 4 damped and undamped frequencles for the 3 pronles calculated for the following soll conditlons: $V_{a}=100 \mathrm{~m} / \mathrm{sec}$ no plle separation considered and dynamle Interaction factors are applled. Table $8.2 b$ gives the Mrst 4 modal soll and structural damping ratlos for the 3 pronles. (It may, be mentloned that the soll shear wave velocities ate deliberately chosen to be low in order to identify the trends observed in a dist/net manner.)

Natural frequencles of the llnear and parabollc profles are lower than those of the constant pronle, with those of the linear pronie betng the lowest. A simllar trend is observed for structural damping ratlos. with the exceptlon of the fourth gode (second torslonal mode) where the structural damping ratlo for the linear. promle is the hlghest. Foundation damplng ratlos show an opposite trend where the damping ratlos for llnear and parabolle soll pronles are higher than the constant profle with the exception of the fourth mode where the foundation i damplng ratlo of the linear pronle is lower than that of the parabollc pronle. It can also be seen that the damped frequencles calculated considering structural damplng only are clooer to the undamped frequencles than those calculated considering foundation damplng only. This is because foundation damping ratios are higher than structural dampine ratlos In this case.

Table 8.3a shows the nrst 4 undamped and damped frequencles for the 3 

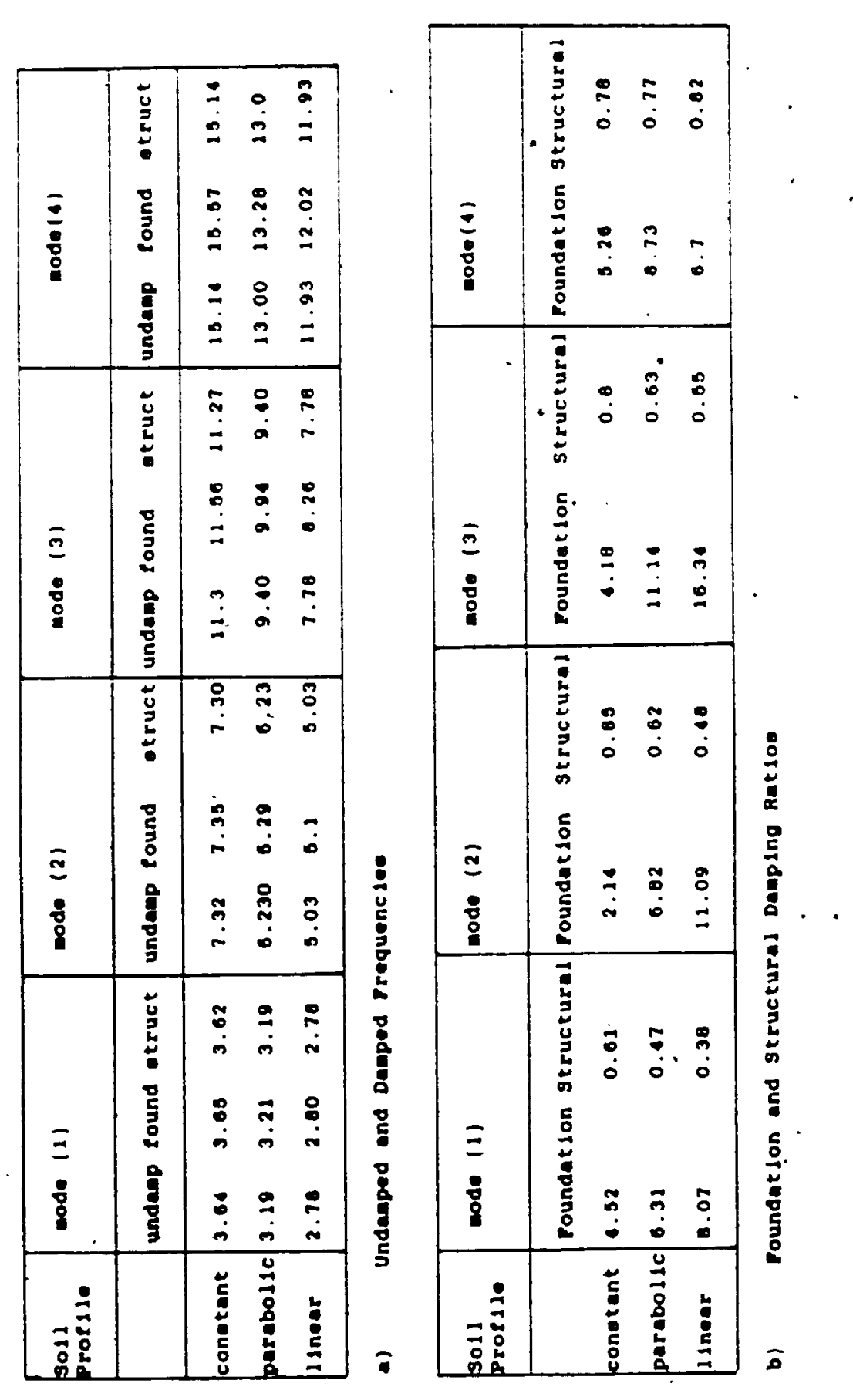

208

Table 8-2: Natural Frequencies and Damping Rat los of the Tower Calculated for Three SoIl Proles $\left(V_{s}=100 \mathrm{~m} / \mathrm{s}\right.$, Dynamic Interaction Considered, PIle Separation Neglected) 



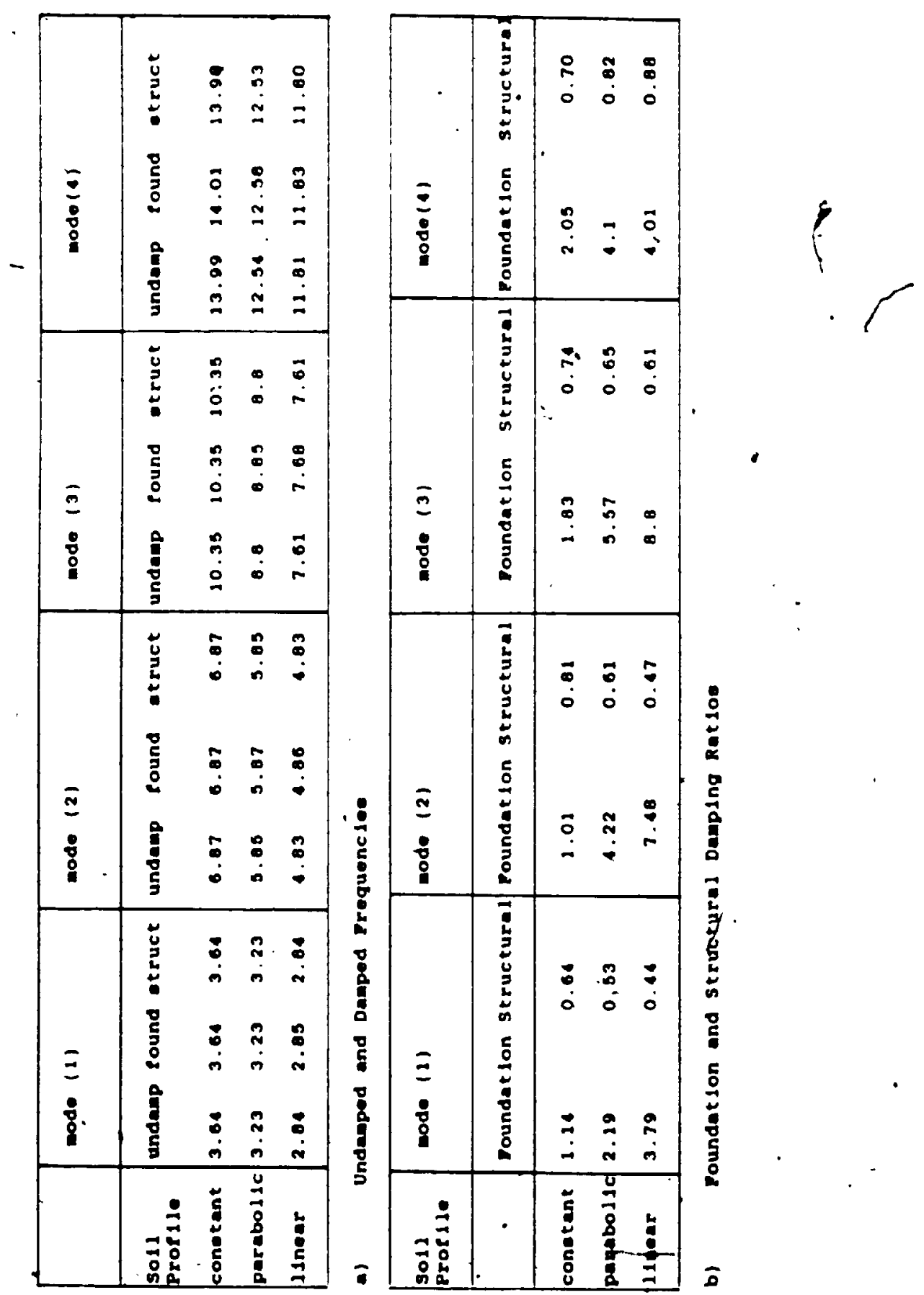

Table 8-3: Natural Frequencles and Damplng Ratlos of the Tower Calculated for Three Soll Pronles $\left(V_{s}=100 \mathrm{~m} / \mathrm{s}\right.$. $e / d=2.0$. Plle-Soll-Plle Interaction Neglected) 

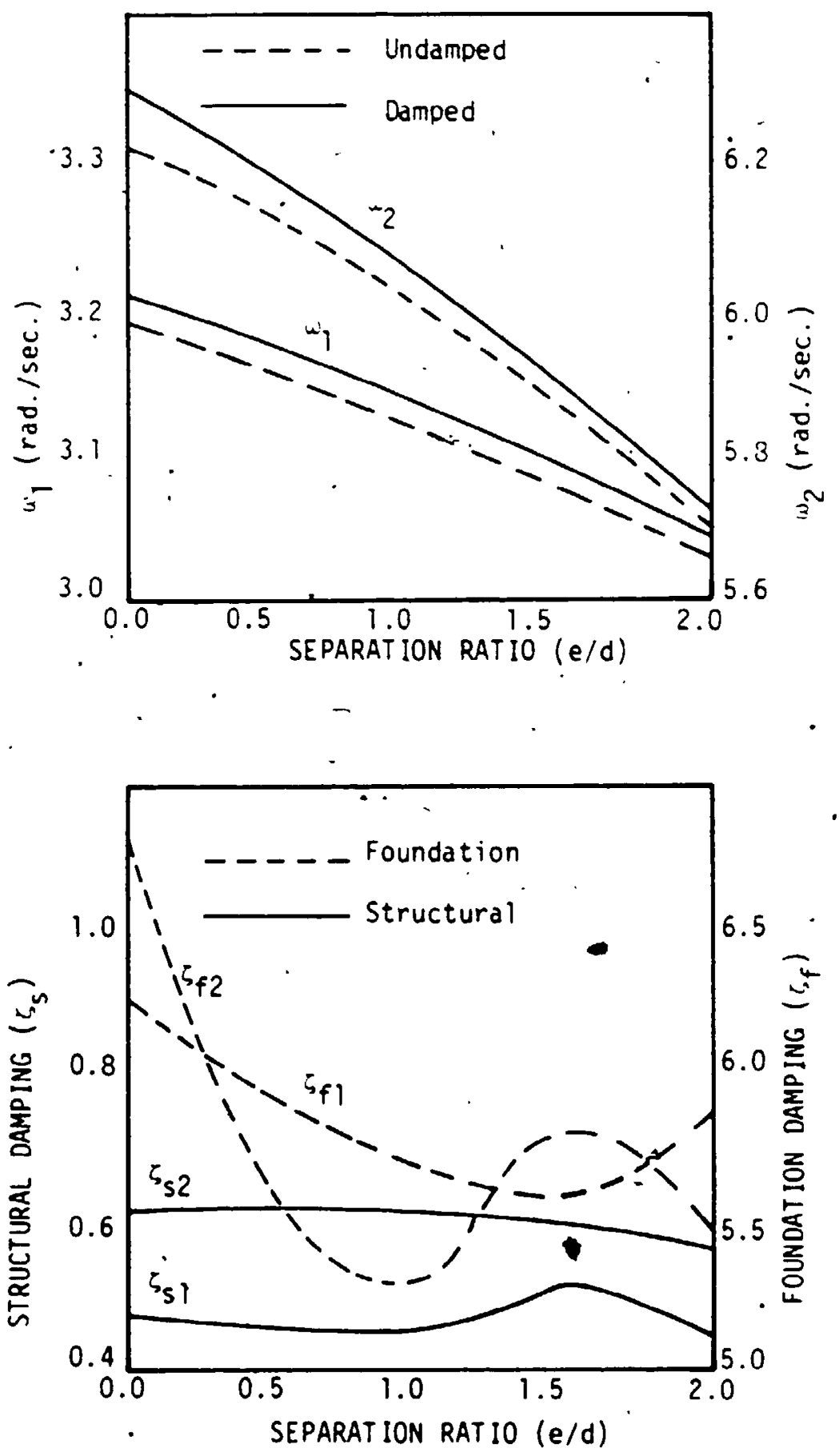

Figure 8-6: Varlation in Natural Frequencles and Damplng Ratlos of the Tower with Plle Separation Ratlo e/d

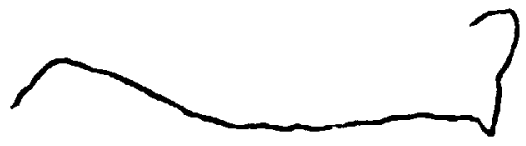



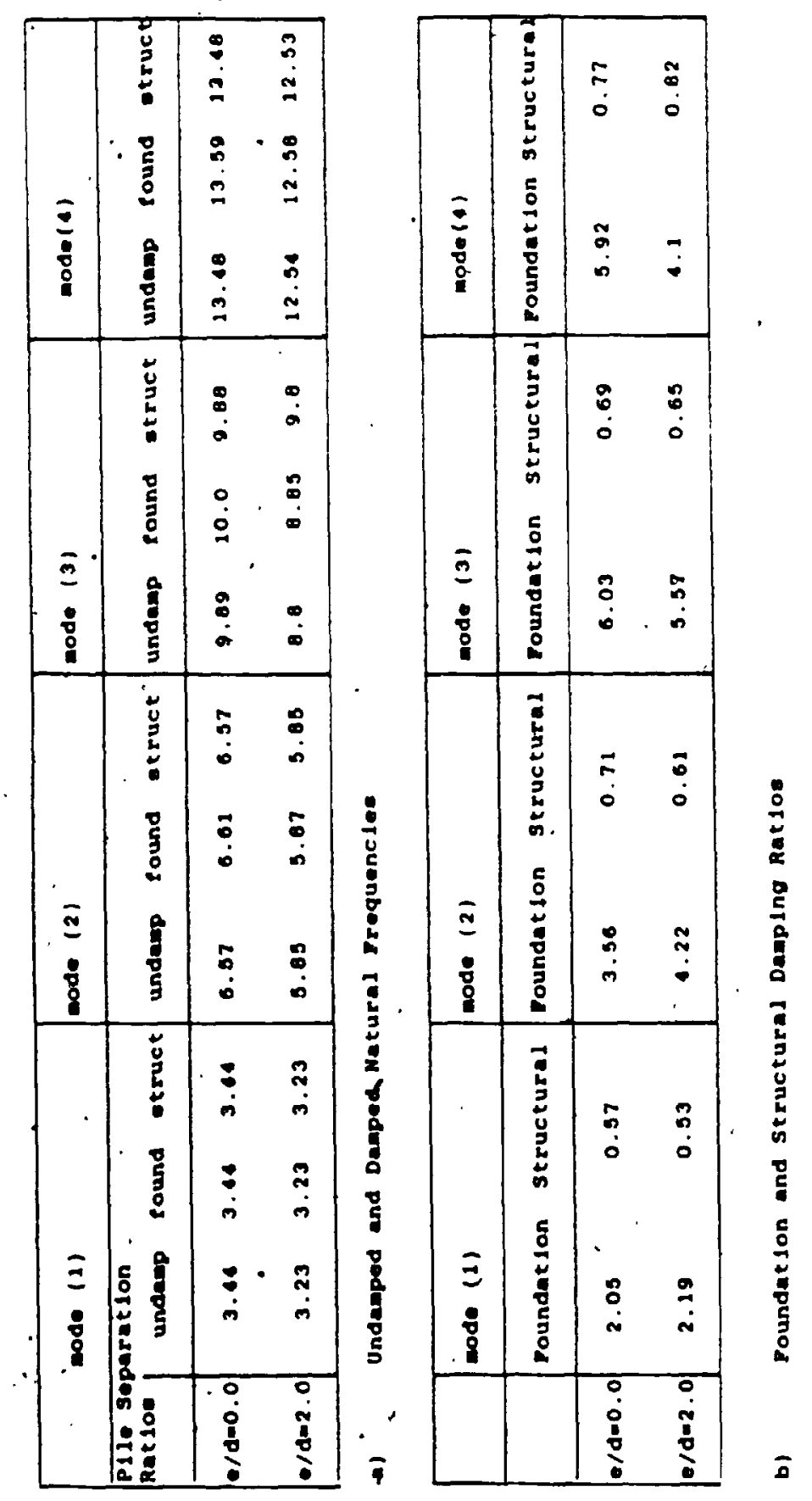

Table 8-4: Natural Frequencles and Damplng Ratlos of the Tower Calculated for Twa Plle Separation Ratios $\left(V_{s}=100 \mathrm{~m} / \mathrm{s}\right.$, Parabolic Soll Pronle. Plle-Soll-Plie Interaction Neglected) 


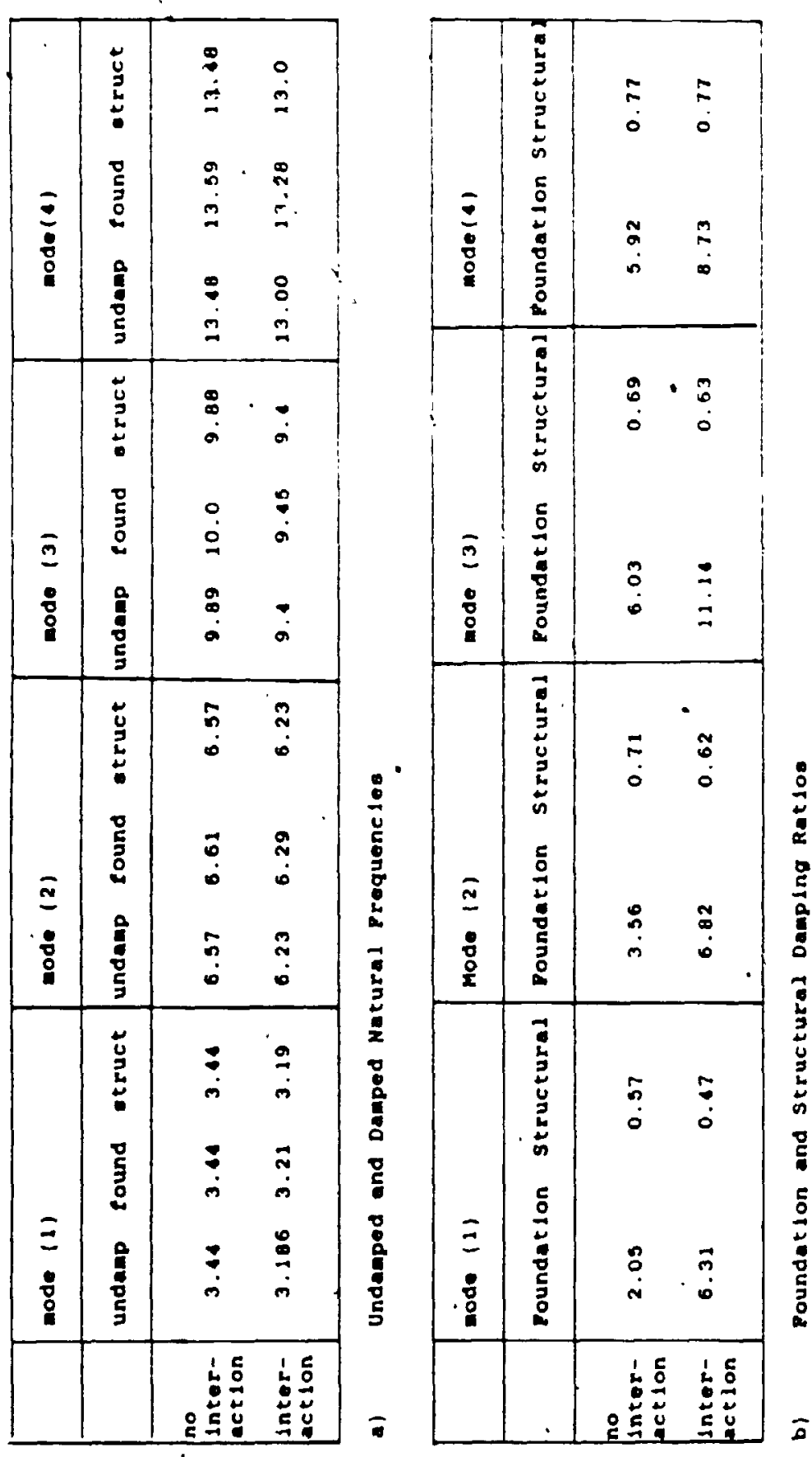

Table 8-5: Natural Frequencles and Damplng Ratlos of the Tower Calculated with and without Interaction $(V=100 \mathrm{~m} / \mathrm{s}$, No Separation,

Parabollc Soll Pronle) 




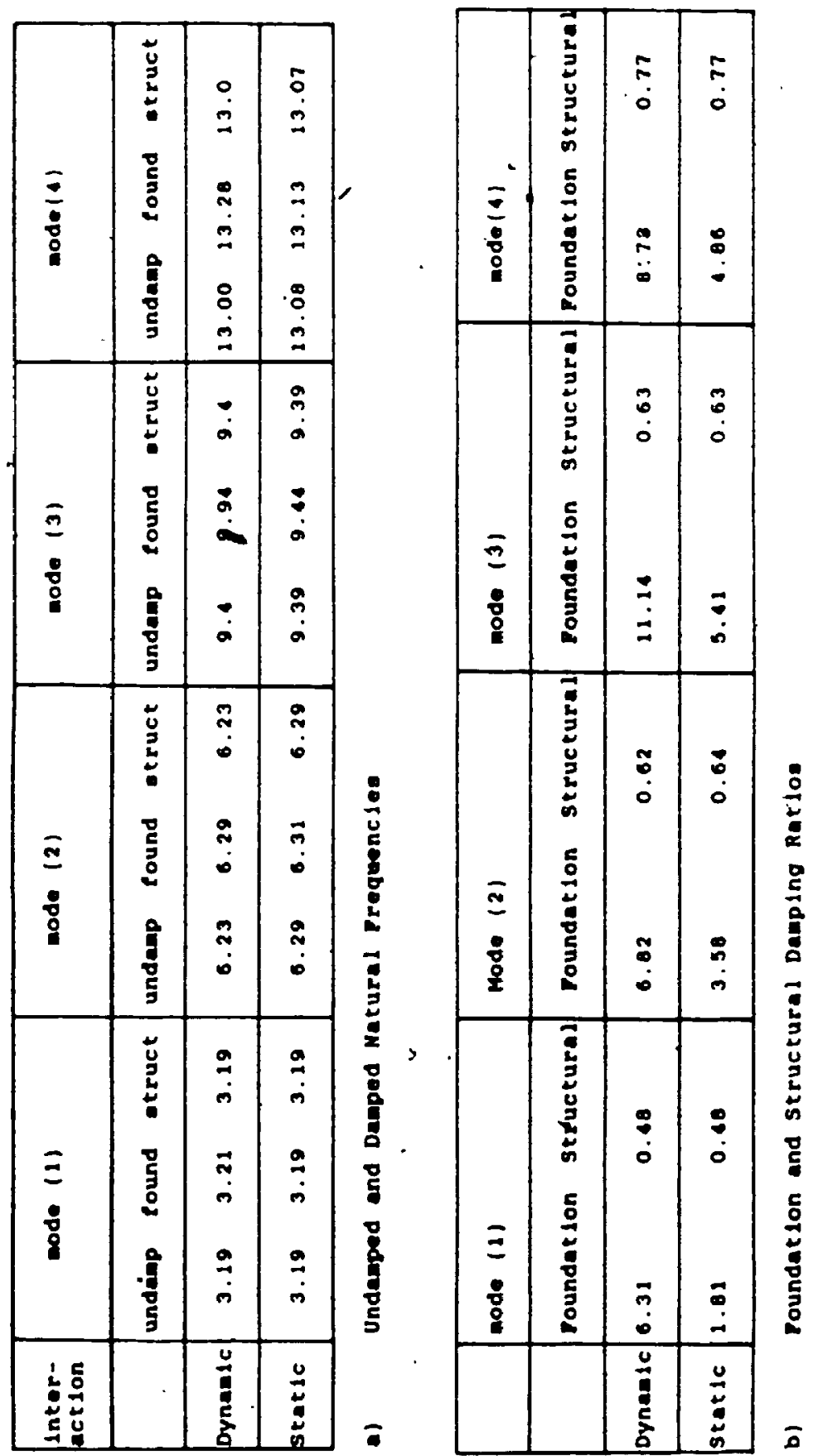

Table 8-7: Natural Frequencles and Damping Ratlos of the Tower Calculated for Static and Dynamic Interaction $\left(V_{s}=100 \mathrm{~m} / \mathrm{s}\right.$.

- No Plle Separation. Parabollc Soll Pronle) 

undamped natural frequency of the tower versus the deck mass. For each value of the deck mass, there is a crltical wind speed at which resonance occurs. For this tower, the critlcal wind speeds corresponding to practical values of the deck mass are very low. However, due to thelr low values they have a high probabllity of occurence and consequently are important in fatigue analysis. Total damping ratlos of the nrst 2 modes are plotted versus deck mass in F/g. 8.9 and it can be noticed that modal damplng as percentage of the critlca! damping drops with the Increase in mass.

\subsection{Variation in Hydrodynamic Damping and Tower Response to Wave Forces With the Different Parameters.}

For all the results presented in thls Section, the dec. mass is assumed to be $63.86 \%$ of the total miss and the exponential decay parameter $c$ is assumed to have a value of 1 unlesilotherulse stated.

\subsubsection{Effect of Soil Stiffness}

Response of tie tower is evaluated for 7 different soll shear wave velocities ranging from 50 to $200 \mathrm{~m} / \mathrm{sec}$ and 2 different wind speeds. 10 and $40 \mathrm{~m} / \mathrm{sec}$. For all cases, a parabollc soll pronle is assumed. plle separation is neglected and dynamle plle-soll-plle Interaction is consldered. Hydrodynamle damping ratlos for the different soll shear wave velocltles are shown in Fig. 8.10 for $C=10$ and 40 $\mathrm{m} / \mathrm{sec}$. As soll shear wave velocity increases. natural frequencies increase. the critical damplng increases and damplng ratlos decrease. This follows the same trend for foundation damping ratlos. The varlation in standard devlation of the top node deflection in direction $X$. for the 2 wind speeds, wilh soll shear uave velocity is shown In Fig. 8.11. At lower wind speeds. the contribution from the resonant part of the response to the total varlance is larger than that of the background part. The magnitude of thls resonant response is controlled by ino 


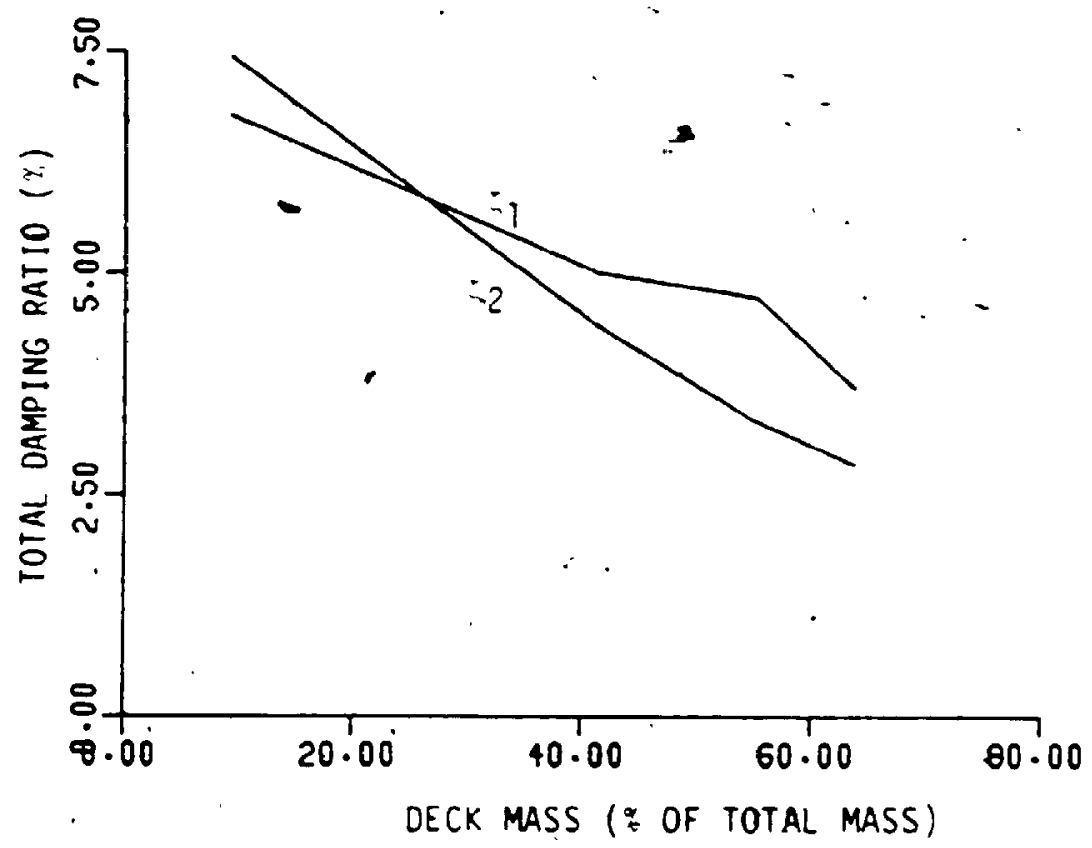

Figure 8-8: Variation In the First Modal Damping Ratlo of the Tower with DeckeMass

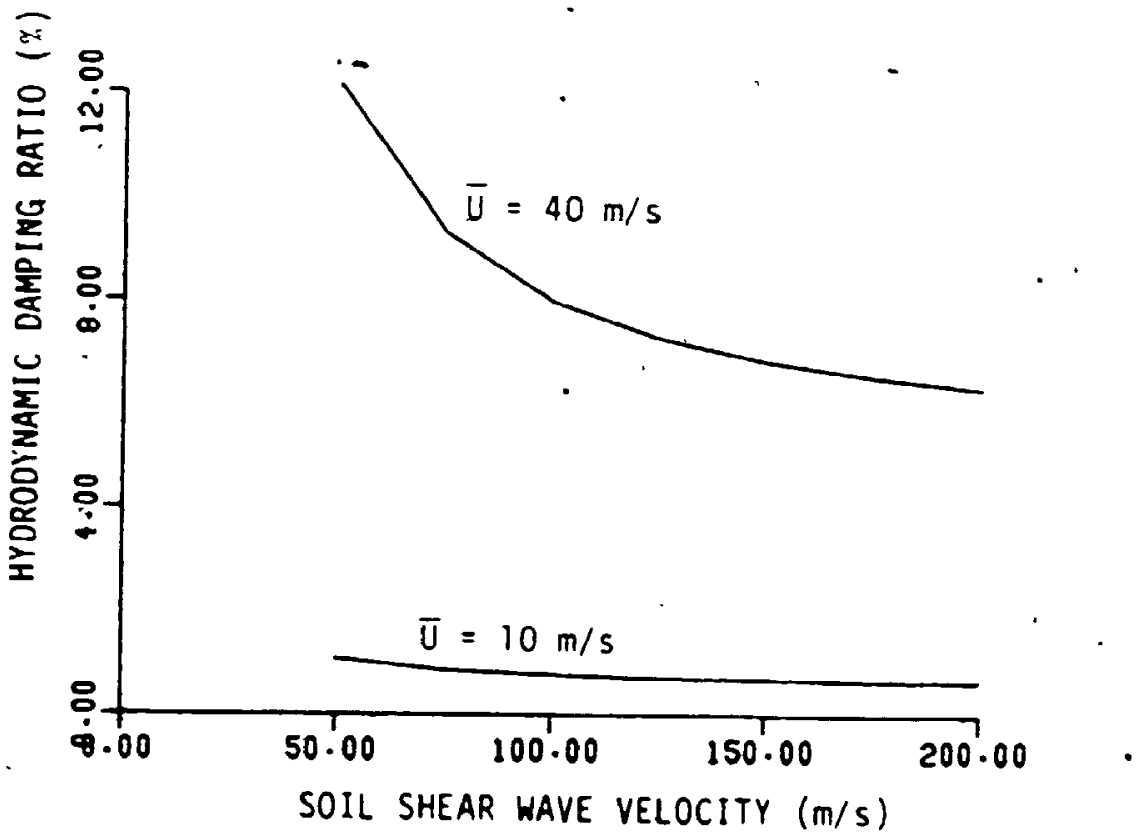

Figure 8-10: Hydrodynamle Damplng Ratlo for Dirferent Soll Shear Wave Velocitles 
-

factors, the proximity of the natural frequencles to the wave energy spectral peak frequency $\bar{a}$ and the damping present in the system as fraction of the critlcal damplng. As soll shear wave velocliy increases, the natural frequency increases moving away from $F$ and the damping ratlo decreases. These 2 factors have opposite effects on the response spectral amplitudes in the viccinity of the resonance frequency. The net effect of these 2 factors is elther to increase or decrease the total response amplltude (standard devlation).

For higher wind speeds, the contribution to the total response from the background component is much hlgher than that of the resonance component. The background response is quast-statlc with llttle or no dynamic amplincation. Thus the magnltude of the background response is controlled by the stiftness of the system. As soll shear wave velocity increases, stirfness of the tower Increases, and the tower response decreases.

This is further lllustrated by Flgs. 8.12 and 8.13 whlch show the spectra of the top node deflectlon for two shear wave velocltes, 50 and $200 \mathrm{~m} / \mathrm{sec}$ calculated at $C=10$ and $40 \mathrm{~m} / \mathrm{sec}$, respectlvely. For $C=10 \mathrm{~m} / \mathrm{sec}, \bar{w}=0.881 \mathrm{rad} / \mathrm{sec}$ and as can be seen, the tower response with the stiffer soll has little energy at thls frequency whereas the tower with $V_{t}=50 \mathrm{~m} / \mathrm{sec}$ has a pronounced peak. However, due to the closeness of $\bar{\omega}$ and $\omega_{0}$ for $V_{a}=50 \mathrm{~m} / \mathrm{sec}$, the response spectrum is somewhat broad banded and the two peaks of the response spectrum can not be distingulshed. The resonant peak for $l=200 \mathrm{~m} / \mathrm{sec}$ is more pronounced than that for $V_{s}=50 \mathrm{~m} / \mathrm{sec}$ desplte $\mathrm{its}$ belng further from $\bar{\omega}$ due to the smallet damplng ratlo assoclated with the former. For $\mathrm{C}=40 \mathrm{~m} / \mathrm{sec}$. Fig. 8.13. the background response dominates the total varlance which is much smaller for $V_{s}=200 \mathrm{~m} / \mathrm{sec}$ than for $I_{s}^{\circ}=50 \mathrm{~m} / \mathrm{sec}$ 


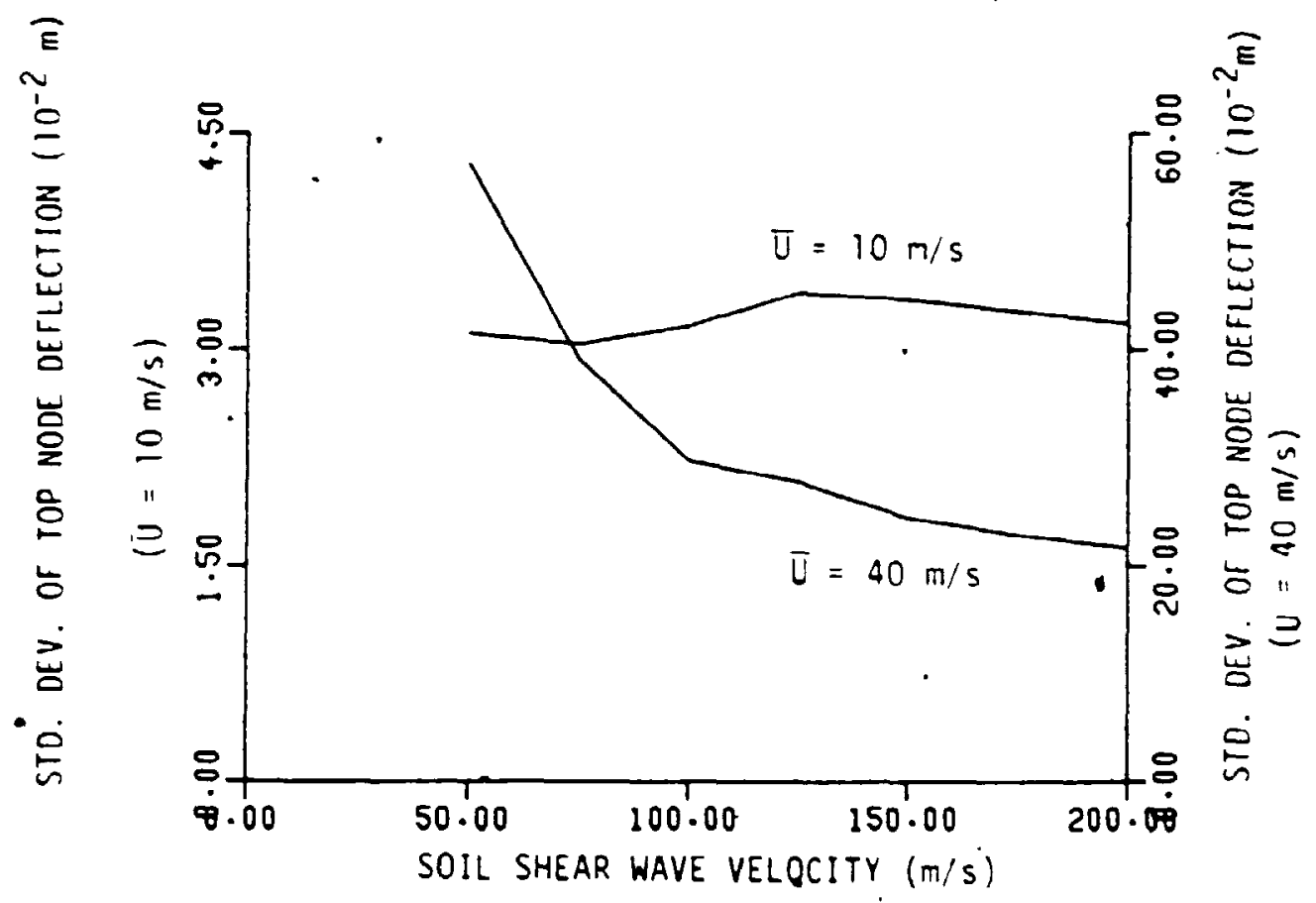

Figure 8-11: Effect of Soll Shear Wave Veloclty on Tower Response to Waves'

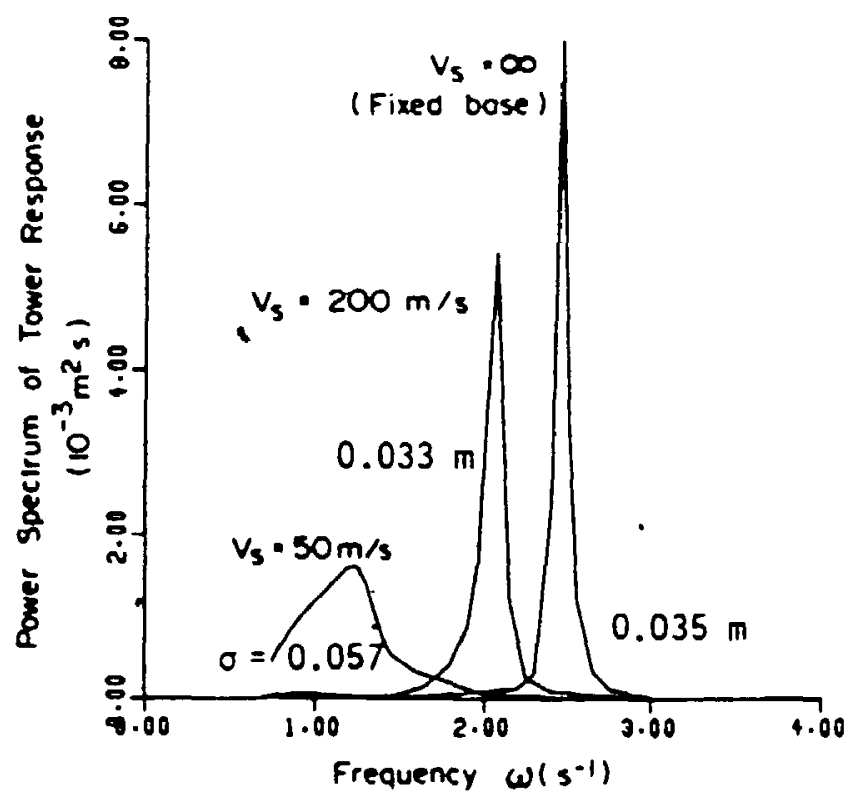

Figure 8-12: Top Node Response Spectra for Three Shear Wave
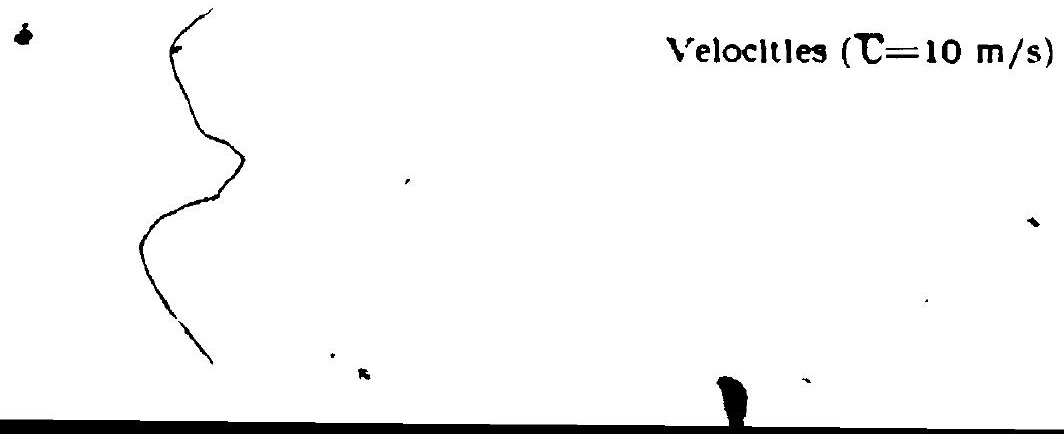


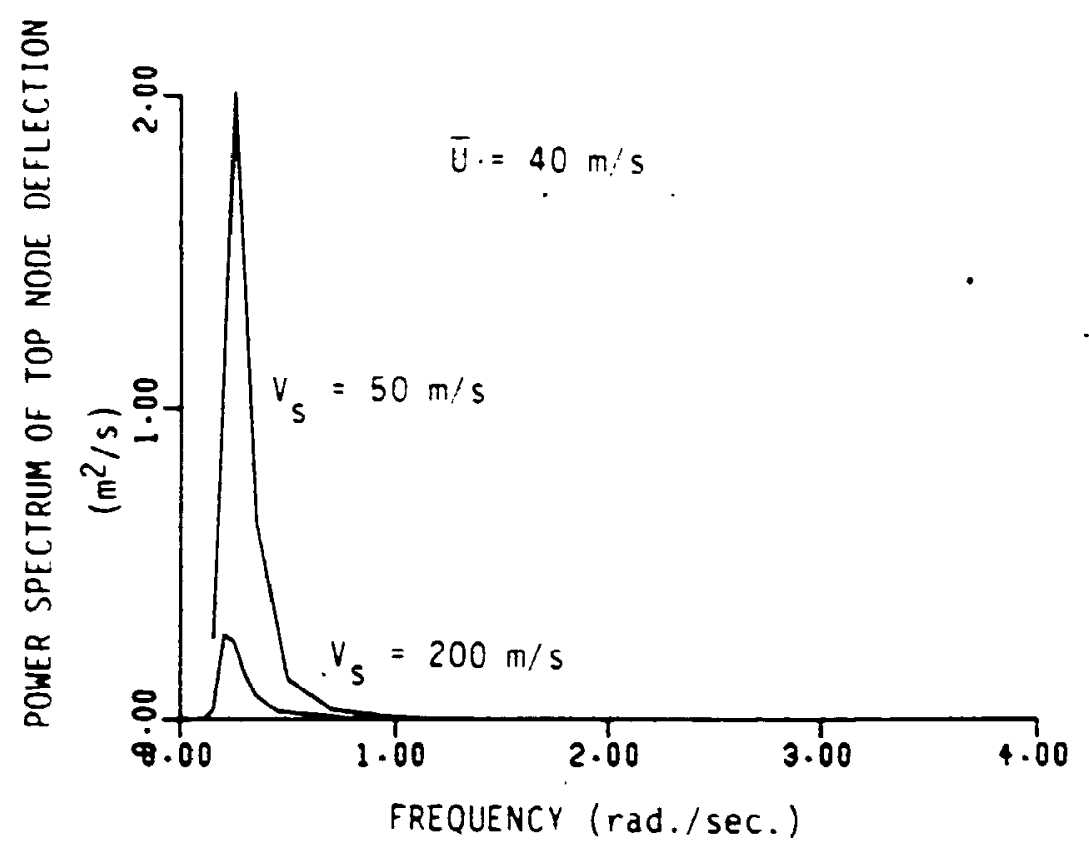

Figure 8-13: Top Tode Response Spectra for Two Different Shear

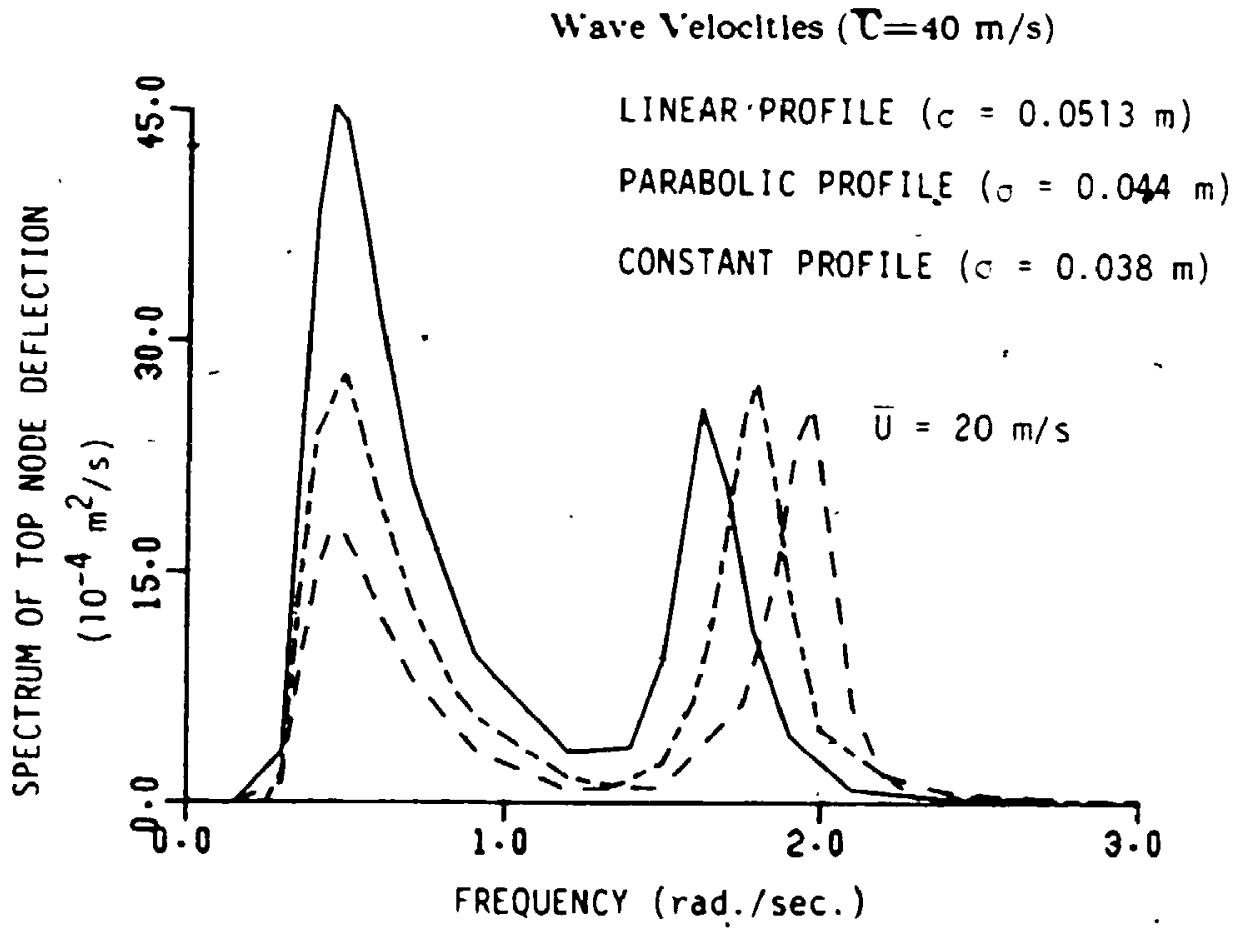

Figure 8-14: Tower Respohse Spectra for Three Soll Pronles 


\subsubsection{Effect of Soil Proffie}

Fig. 8.14 Illustrates the effect of soll pronle on the tower response. In thls ngure, the power spectrum of the top node deflection is plotied for the 3 shear wave velocity pronles and $\mathrm{C}=20 \mathrm{~m} / \mathrm{sec}$. At such an Intermediate wind speed. contributlons from the background and resonant components to the total varlance are both of equal importance. The tower with the llnear soll profile has the least stimness and consequently, the highes response spectral amplitudes in - the vicinlty of $\Xi$. The nrst undamped natural frequencles and the nrst modal damplng ratlos of the tower corresponding to the 3 pronles are glven in Table 8.8. Although the towers with the llnear and parabollc pronles have a higher damplng ratlos than that with the constant pronle. the resonant peaks for the 3 cases are almost equal because the nrst natural frequencles of the former towers are closer to $\bar{w}$ than that of the latter. For thls wind speed, the tower with the linear pronle has the highest standard devlation and is $35 \%$ larger than that of the tower wlth the constant pronle.

\subsubsection{Effect of Pile-Soil-Pile Interaction}

The tower response is evaluated for three different wind speeds 10, 22 and 30 $\mathrm{m} / \mathrm{sec}$ with plle-soll-plle interaction neglected and considered. Fig. 8.15 shows the power spectrum or top node deflectlon for both cases for the 3 wind speeds, respectively. For lower wind speeds, the resonant peak is dominant and when plle-soll-plle interaction is consldered. foundation. and hydrodynamlc damping ratlos Increase and the resonant peak is suppressed. This leads to a total varlance which is less than that when the plle-soll-plle interaction is neglected. At hlgher wind speeds. the background response peak is dominant and considering plle-soll-plle Interaction Increases the nexlbllyy of the tower. Consequently. plle-soll-pile Interaction Increases the total varlanse of the tower response at hlgher wind speeds. For Intermediate wind speeds, both peaks might 


\begin{tabular}{|c|c|c|}
\hline Soll Profile & Natural Frequency & $\begin{array}{c}\text { Damping Ratio } \\
\omega_{2}\end{array}$ \\
\hline Linear. & 1.62 & 0.049 \\
\hline Paraboljc & 1.79 & 0.047 \\
\hline Constant & 1.97 & 0.034 \\
\hline
\end{tabular}

Table 8-8: Flrst Natural Frequencles and Modal Damping Ratlos Calculated for Three Soll Pronles $\left(l_{s}=100 \mathrm{~m} / \mathrm{s}\right.$. No Plle Separation.

Dynamic Plle-Soil-Plle Interaction)

\begin{tabular}{|c|c|c|c|c|c|}
\hline $\begin{array}{l}\text { Wind } \\
\text { Speed } \\
m / 8\end{array}$ & $\begin{array}{l}\text { Plle } \\
\text { Inter- } \\
\text { action }\end{array}$ & $r_{h}$ & $\frac{a_{b}^{2}}{0}$ & $\frac{0^{2}}{0^{2}}$ & 0 \\
\hline 20 & $\begin{array}{l}\text { No } \\
\text { Yes }\end{array}$ & $\begin{array}{l}0.72 \\
0.72\end{array}$ & $\begin{array}{l}0.03 \\
0.09\end{array}$ & $\begin{array}{l}0.97 \\
0.91\end{array}$ & $\begin{array}{l}0.047 \\
0.032\end{array}$ \\
\hline 22 & $\begin{array}{l}\text { No } \\
\text { Yea }\end{array}$ & $\begin{array}{l}2.46 \\
2.69\end{array}$ & $\begin{array}{l}0.50 \\
0.68\end{array}$ & $\begin{array}{l}0.50 \\
0.32\end{array}$ & $\begin{array}{l}0.050 \\
0.050\end{array}$ \\
\hline 30 & $\begin{array}{l}\text { No } \\
\text { Yee }\end{array}$ & $\begin{array}{l}4.24 \\
4.62\end{array}$ & $\begin{array}{l}0.88 \\
0.95\end{array}$ & $\begin{array}{l}0.12 \\
0.05\end{array}$ & $\begin{array}{l}0.095 \\
0.108\end{array}$ \\
\hline 10 & $\begin{array}{l}\text { No } \\
\text { Yes }\end{array}$ & $\begin{array}{l}7.22 \\
7.98\end{array}$ & $\begin{array}{l}0.99 \\
0.99\end{array}$ & $\begin{array}{l}0.01 \\
0.01\end{array}$ & $\begin{array}{l}0.269 \\
0.316\end{array}$ \\
\hline
\end{tabular}

Table 8-9: Tower Response to Wave Forces and Hydrodynamlc Damping Ratlos for Different Wind Speeds Calculated Elther Neglecting or Considering Plle-Soll-Plle Interaction $\left(V_{s}=100 \mathrm{~m} / \mathrm{s}\right.$. Parabollc Soll Pronle) 

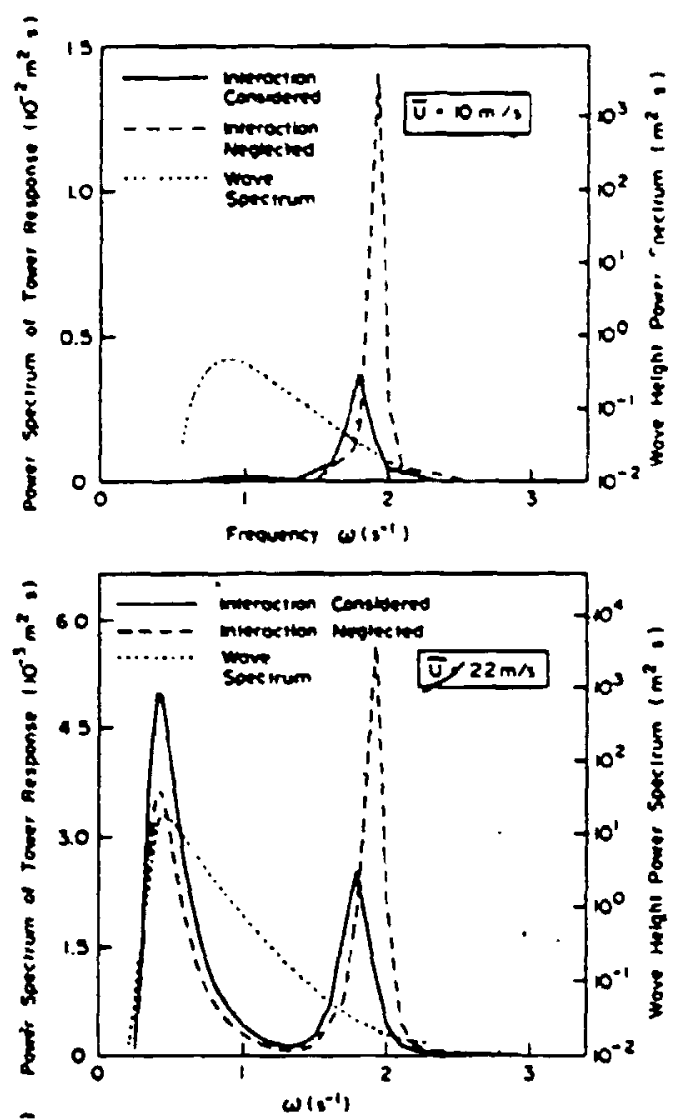

$\because$

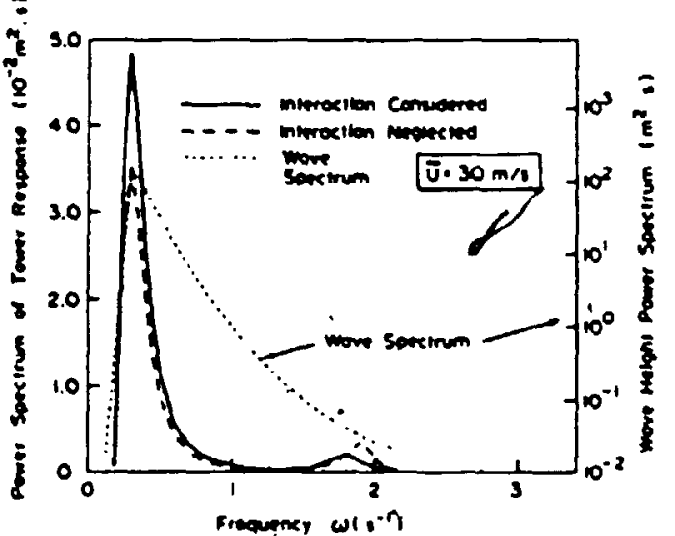

Figure 8-15: Effect of Plle Soll Plle Interaction on Touer Response Spectrum for Three Different Wind Speeds 
be of equal Importance and consldering plle-soll-plle Interaction may increase or decrease the total varlance.

To illustrate the variation in the contribution to the total varlance from the background and resonant components. the total varlance $\sigma^{2}$ is spllt into 8 background varlance $\sigma_{b}^{2}$ and a resonant varlance $\sigma_{r}^{2}$ and both are expressed as ratlos from the total varlance. Table 8.9 glves the foundation dampling ratlos, the hydrodynamic damplng ratlos, $\sigma_{b}^{2} / \sigma^{2}, \sigma_{r}^{2} / \sigma^{2}$. the total varlance and the standard deviation of the top node deflection for 4 different wind speeds all elther considering or neglecting plle-soll-plle interactlon. At $\mathrm{C}=22 \mathrm{~m} / \mathrm{sec}$ the increase In background response when considering plle-soll-ptle interaction is compensated for by the decrease in the resonant response and the standard devlation of both cases is the same.

Fig. 8.16 shows the, varlation in hydrodynamlc damping ratlos with wind speed for $V_{s}=100 \mathrm{~m} / \mathrm{sec}$, parabolic soll pronle and plle separation neglected, wilh and without plle-soll-plle Interactlon. The hydrodynamlc damplng ratlos increase substantlally with wind speed and they are greater when considering plle-soll-plle 10 raction. Fig. 8.17 shows the varlation in standard devlation of the tower top node deflection with the charactertstic wind speed $\boldsymbol{C}$ considering and negtecting pile-soll-plle interaction. The reduction In the response at lower wind speeds and the Increase in the response at higher wind speeds due to plle-soll-plle Interaction is clearly lllustrated in this ngure.

\subsubsection{Effect of Exponential Decay Parameter}

Fig. 8.18 shows the varlation in standard devlation of top node deflection with values of $c$ ranging from 1 to 10 for $T=30 \mathrm{~m} / \mathrm{sec}$. The soll promle considered is parabollc with $l_{n}=100 \mathrm{~m} / \mathrm{sec}$, plle separatlon neglected and pllesoll-plle Interaction is considered. Btandard devlation of the response decreases 



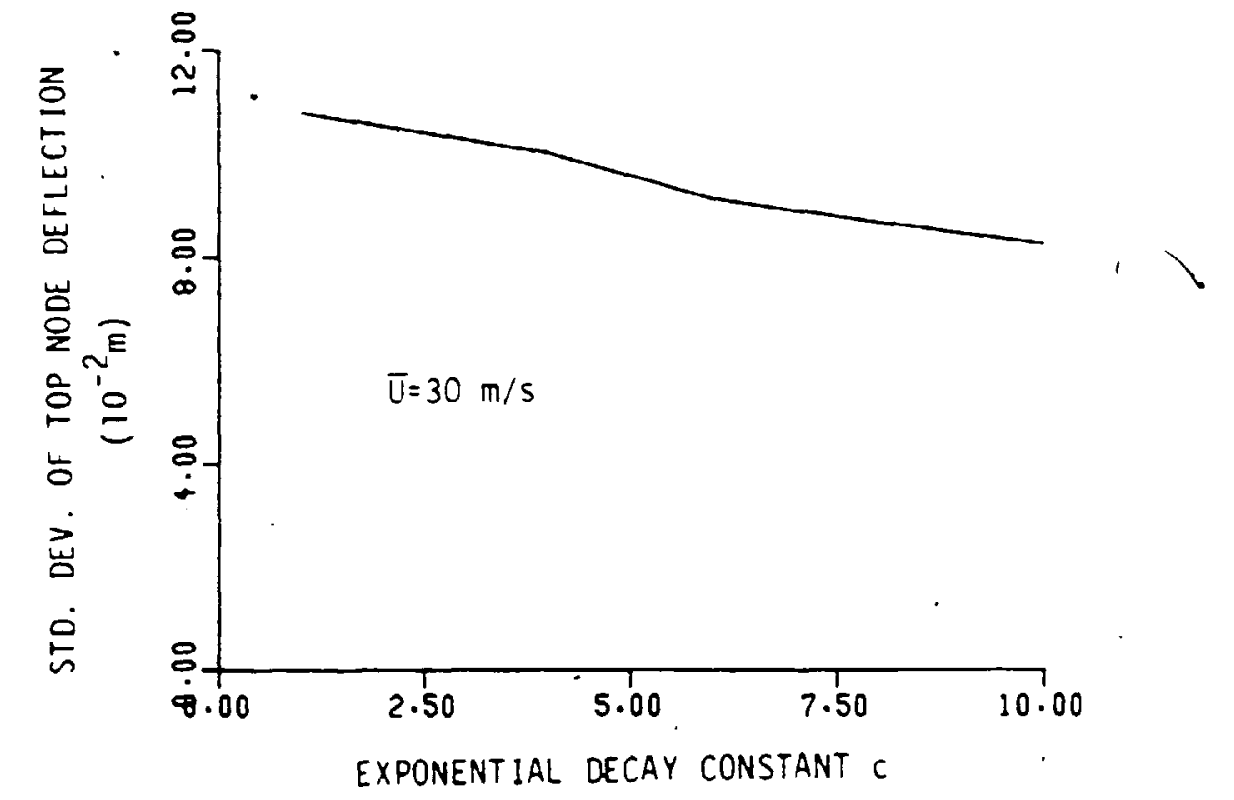

Figure 8-18: Efrect of Exponential Decay Parameter on Tower Response

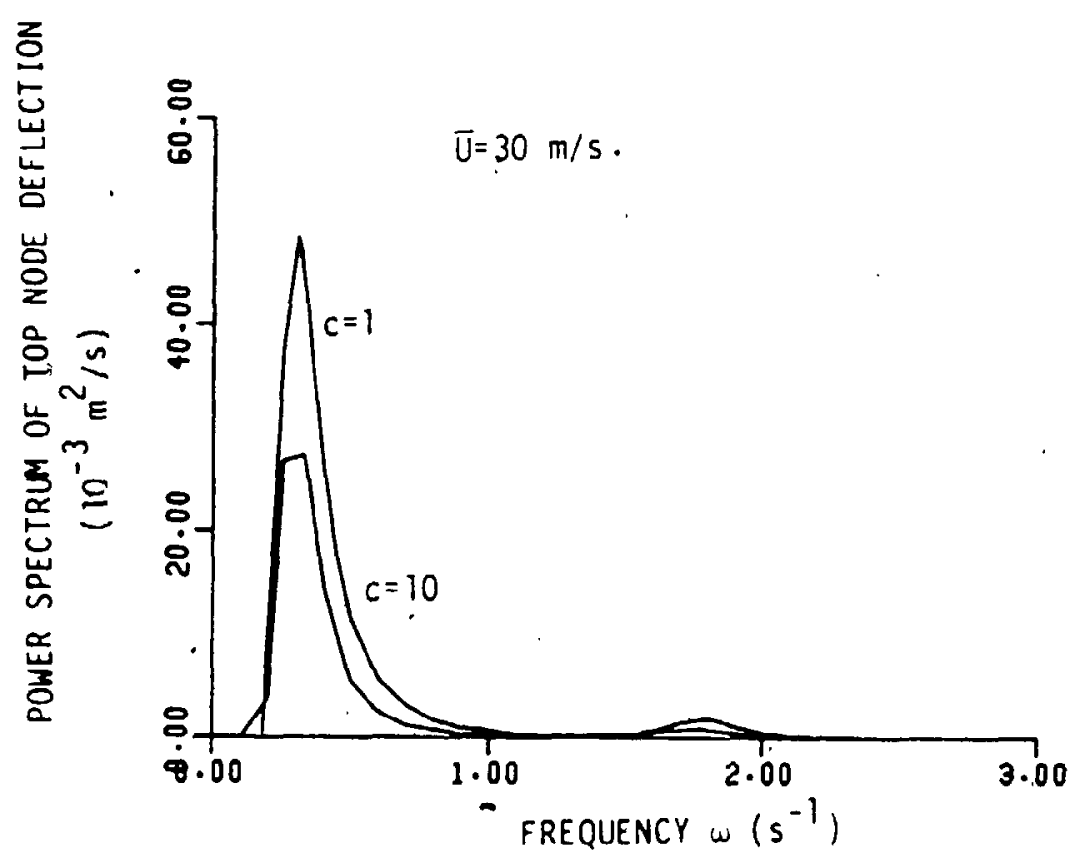

Figure 8-18: Top Node Response Spectra for Two Values of the Exponentlal Decay Parameter 
by $23 \%$ when Increasing the value of $c$ from 1 to 10. Shoun In Fig. 8.19 are the response spectra evaluated at $T=30 \mathrm{~m} / \mathrm{sec}, t=100 \mathrm{~m}$ 'sec. parabollc soll pronle. plle separation neglected and plle-soll-plle Interaction consldered for $c=1$ and 10 . The decrease in the exponential decay parameter decreases the magnltude of wave forces throughout the whole frequency range ulth a slmilar effect on the response spectrum.

\subsubsection{Effect of Deck Mass}

The varlation in the response standard deviation with the deck mass is shown for $\mathrm{C}=22 \mathrm{~m} / \mathrm{sec}$ in Fig. 8.20. As the deck mass increases, the natural frequencles decrease and get closer to the wave energy spectral peak and the foundation damplng ratlos also decrease. Thus increasing the mass of the tower Increases both the background and resonant responses. An Increase in the total mass of the tower by a factor of 2.48 leads to an increase in the standard devlation of the top node deflectlon by $17 \%$.

\subsubsection{Conclusions}

A parametrlc study is carrled out to lllustrate the effect of the foundation system propertles and the wave system parameters on the free vibration characteristics as well as the response of a typical nxed offshore tower. The following concluslons are drawn:

1. Natural irequencles drop dramatlcally with the Increase in soll nexlbllity.

2. Whlle structural damping ratlos drop signincantly with the Increase in soll nexlbllity. tower damping derived from soll Increases with soll nexiblitity.

3. Foundation damplng ratlos are much higher than structural damplng ratlos in the practlcal range of soll propertles encountered in offshore towers and can not be excluded in any reallstlc analysis.

4. The drop in structural damping ratlos due to soll nexibllity is more than compensated for by the Increase in foundation damplng ratlos. 


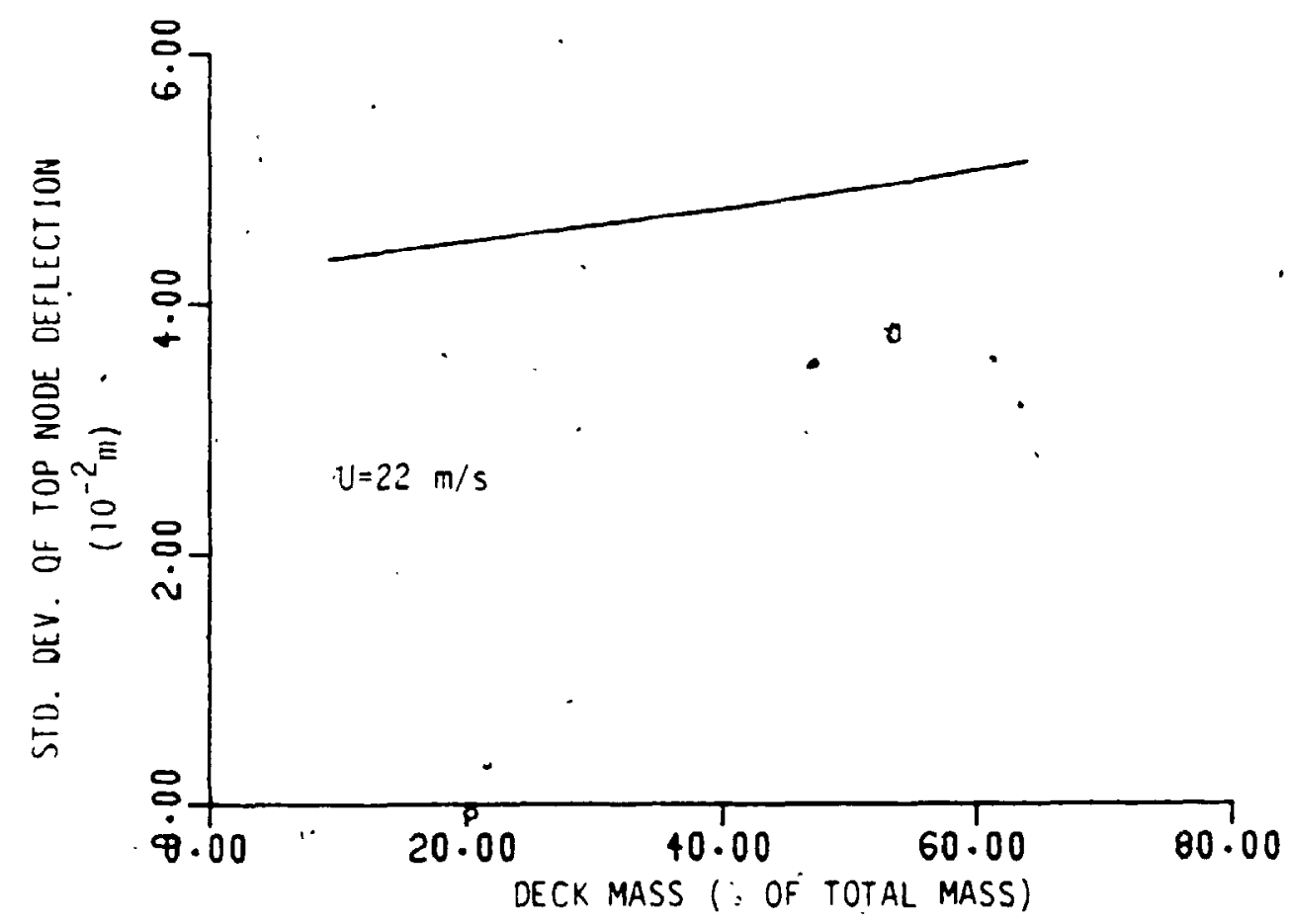

Figure 8-20: Effect of Deck Mass on Tower Response

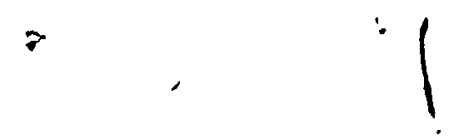


5. Natural frequencles and structural damplng ratlos for llnear and parabolle soll proflles are lower than those of the constant pronle with those of the llnear pronle belng the lowest. Soll damping ratlos follow an opposite trend where those of the linear and parabollc soll pronles are higher than those of the constant pronle with those of the linear pronle belng the highest.

6. Plle separation slightly afrects natural frequencles and damplng ratlos If considered simultaneously with plle-soll-plle Interaction since the two parameters have opposite effects on' the results. Natural frequencles and structural daming ratlos decrease slightly with pile separation while foundation damping increases slightly with the separation.

7. When plle separation is considered in absence of mle-soll-plle Interaction. the drop in natural frequencles and siructural damping ratlos Increases while the increase in foundation damping ratlos is still moderate.

8. Dynamle plle-soll-plle interaction moderately decreases the natural frequencles and structural damplng ratlos but dramatlcally increases foundation damping raclos.

8. The use of statle Interaction factors adequately predicts the natural frequencles and structural damplng but grossly underestimates foundarlon damplng ratios.

10. Dynamlc plle-soll-plle Interaction, usually neglected if design, has a slgnincant effect even with large spacing and should be considered.

11. Hydrodynamlc damping ratlos decrease with the Increase in soll shear wave veloclty.

12. The Increase in soll shear wave veloclty may decrease or Increase the tower response at low wind speeds, but it decreases the tower response at hlgh wind speeds.

13. Soll shear wave veloclty pronle has a signincant effect on the tower response. Pllesioll-plle Interaction Increases the hydrodynamlc damplng ratlos for all wlod speeds.

14. The background part of the response Increases while the resonant response decreases when consldaring plle-soll-plle Interaction. 
15. The total response of the tower to wave forces decreases due to pllesoll-plle Interaction at low wind speeds but increases at high wind speeds.

ib. For the partlcular tower analysed. the total response decreases by 23 $\%$ when the value of the exponentlal decay parameter increases from 1 to 10.

17. Increasing the deck mass (and consequently the tota! mass) or the tower, Increases the response of the tower to wave forces. 


\section{Chapter Nine Summary and Conclusions}

Three main prablem areas are investigated in this study:

1. The analysls of plle diling and prediction of bearing capacliy.

2. Evaluating uave force spectrum on members of offshofe structures accounting for lack of spatlal correlation of random uaves.

3. The dynamic response of nxed offshore structures accounting for pilesoll-plle interaction.

\subsection{Pile Driving}

An Improved one dimenslonal wave equation analysls is developed which accounts for wave propagation in the soll mass. Also a three dimensional nnite element analysls of the problem is formulated and lis results are compared with the one dimenslonal model to lllustrate the advantages and llmitatlons of both models. The following concluslons emerge:

i. The new soll model for the one dimenslonal analysts has the advantage of accounting for wave propagation in soll in a way related to fundamental soll propertles and maj glve more'reallstlc results for plle tlp dispiacements and face and veloclty time records than the conventlonal one dimenslonal model does.

2. The transmitting boundary developed for the nnlte element analysts can be used for both statlc and dynamic problems and as lis parameters are relatlvely frequency independent; it can also be used for a Ulme domain analysis.

3. Ling a viscous boundary in the plle driving problem creates an artinclal offset of the response which may distort the calculated permanent plle set.

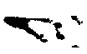

4. The Inlte element analysls is at least two orders of magnitude more expenslve than the one dfrienstonal analysts and does not guarantee better results because it also is very sensitlve to the input parameters.

5. The extent of the reakened zone ground the plle shaft has to be evaluated from comparison with extensive neld data. 


\subsection{Wave Force Spectrum}

A model for evaluating spectra of uave forces on members of the jache: is pe. structure is developed whlch takes into account the lack of spatial correlition

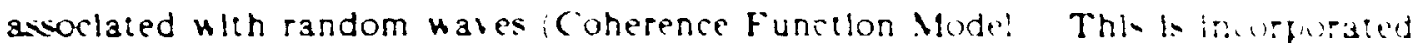

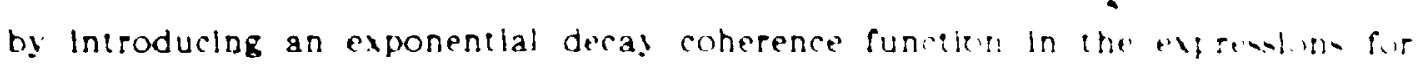
wave kinematles spertra. Wate forces calculated using thi nide are cumbard

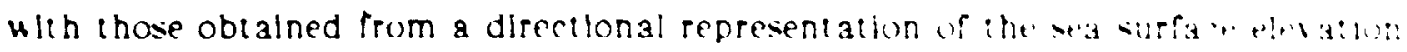

The following conclusions are drawn:

1. Both. the directlonal spectrum and coherence function m it. is priture modincations of the same general nature to the wabe forcen ibtitivid from a one dimensional fully correlated have model. Then art the reduction in the along wave forces and the attenuation of wave forite on two members as the separation increases.

2. The wave forces calculated from boih models mas be in giod agreement ir the parameters of both models are properly chosen

3. The coherence function model falls to represent the ratlo bet uetn the two horizontal force components only when the mean diretion of wave advance is such that one of the ixin force components is small.

4. The coherence function model appears 10 be a better model for evaluation of the along wave force component as it incorporates the lack of spailal correlation lyplcal of short crested waves and offer substantlal computatlonal advantages.

\subsection{Response of Fixed Offshore Towers}

The coherence function model and plle-soll-plle Interaction are incorporated In the general model for solving the response of the touer to random waves. Pilesoll separation is accounted for. Drag forces are llnearlzed and the analyst is carrled out in terms of the theory of random vibration. The effects of both the foundation and wave loading parameters on the dynamis propertles an well as the response of the tower are Investlgated and the following concluslons are draun:

1. Fuundation damplng is the major source of dampling at lou uind speeds whlle the hydrodynamle damplng is the maln source at high ulnd speeds. 
2. Dynamic plle-soll-plle Interaction. usually neglected in design, has a signincant effect even with large plle spacing. It markedly increases the damplng derlved from the foundation.

3. Dynamle plte-soll-plle interaction Increases the bachground retpony of the tower but decreases the resonant response.

4. Whtle the total response of the tower increave's due in plle-sill-plin interaction at higher $\mathrm{w}$ ind speeds. It decreases at lower $\mathrm{H}$ ind speed

\subsection{Recommendations for Further Research}

The nature of pile-soll force transfer mechanism during plle drung is not fully understood and lts modelling is basic to the understanding of the driting process. The proposed model parameters should be evaluated in a stathilcal manner based on a large number of load tests.

Although both of the directlonal spectrum and coherence function models can yleld simllar results there is a need to establish the parameters of both models through comparlsons with experimental data.

The Interaction factors used in inls siudy are baned on a linear solution whlch may exaggerate the effects of plle interaction. A more reallictic analysi should include soll nonllnearlly.

However, It should be noted that the accuracy of the models presented hereln depends on the rellabllity of the Input parameters. With regard to the uncertaintles assoclated with these parameters. partlcularly with the will propertles. safety of offshore structures should be further studled. 


\section{References .}

1. Smith. E.A.L.. "Plle Drting Analysls by the Wave Equation". ASCE, Transactlons. Paper . No. 3306. Vol. 127. Part 1.. pp. 1145-1170.

2. Bes. R.G. "Dynamic Response of Marine Foundations", Keynote paper for Ocean Structural Dynamles Symposium 84. Sept. 11-13. 1984. Oregon State Linlverslty.

3. "Planning and Design .ef Flxed Orfshore Platforms". McClelland, B. and Relfel, M.D. (Edltors), Van Nostrand Relnhold Company. 1886 .

4. Vickery. B.J., "Wind Loads on Compllant Offshore Structures". Proceedlngs of the Symposlum on Ocean Structural Dynamles. Dept. of Civil Engineering. Orezon State Lniverslty. Corvlllas. Oregon. Sept. 8-10. 1982.

5. Strlckland, G.E.. Brooks. L.D. and Pearce, J.C.. "Ice Forces", Chapter 3 in "Planning and Deslgn of Fixed Orrshore Platforms". McClelland. B. and Relfel, M.D. (Edltors). Van Nostrand Relnhold Company, 1888.

6. Davls, R.O. and Phelan. P.J.. "Numerical Approximation In Plle. Driving Analysts". Technlcal Note, Internatlonal Journal for Numerlcal and Analytical Methods In Ǵeomechanles, Vol. 2. 1978. pp. 303-310.

7. Matlock. H.M. and Foo.. S.C. "Axlal Analysls of Plles Lising a Hysteretlc and Degrading Soll Model". Conference on Numerical Methods in Oftshore Plling". Institution of CIvll Engineers, London, 1880. pp. 127-133.

8. Holloway. D.M. and Dover, A.R., "Recent Advances In Predicting Plle Drlvabllity". Orrshore Technology Conference, Houston, Texas, 1878. OTC 3273.

9. Heerema, E.P. and de Jong. A.. "An Advanced Wave Equation Computer Program Whlch SImulateg Dynamic Plle Plugging Through a Coupled Mass Spring System", Numerical Methods in Orfshore Plling. Institution of Civll Englneers, London, 1980. pp. 37-42. 
10. Goble. G.G. and Hery. P.. Innuence of Resldual Forces on Plie Drliabllity". Second International Conference on the Application of Stress Wave Theory on Plles. Stockholm. Sweden. May 1984.

11. Rausche, F.. Goble. G.G. and LIkIns, GF.. Jr.. -Dinamic Determination of Plle Capacty ". ASCE. J. of Cicotechnlcal Fing Dir.. rol. 111. No. 3, March 1985, pp. 38\%-383

12. Novak. M.. Nogaml. T. and Aboul Ella. F.. "D!namic soll Roatiunfor Plane Strain Casen. ASCE. J. Eng. Mechanics Dluision. Vol. 101 1858, pp. 853-858.

13. Samson, C.H., Hirsch. T.J. and Lowery. L.L. Jr.. "Computer study of Dynamle Behavlour of Plling". ASCE. Vol. 89. No. STt. August. 1983. pp. $413-449$.

14. Timoshenko. S. and Goodler. J.Ml. "Theory of Elastlclty". McGian HIII Book Co., Second ed., 1951.

15. Litkouhl, S. and Poskltt, T.J., "Damping Constants for Plle Drivabllity Calculations". Geotechnlque, Vol. 30. No. 1, 1980. pp. $77-86$.

16. Smlth, E.A.L., "Impact and Longltudinal Wave Transmission". Transactlons, ASME, August, 1955. pp. 983-973.

17. Smlth. I.M. and Chow, Y.K., "Three Dimensional Analysis of Plle Drlvabllity". Proc. of the Second International Conference. Numerlcal Methods In Offshore Plling. Austin. Texas, 1982. pp. 1-18.

18. Chow. Y.K. and Smith. I.M.. A Numerlcal Model for the Analysls of Plle Drivabllity". Second Internatlonal Conference on the Application of Stress Wave Theory on Plles. Stockholm. Sweden. May 1884.

19. Goble, G.G. and Rausche, F., "Plle Drlvabllity .Predictlons by Capwap". Numerlcal Methods in Orfshore Plling. Instltution of Civill Engineers, London, 1980. pp. 29-38.

20. Wu, A.K.H. Kuhlemeyer, R.L. and To, C.W.S." "Plle Shaft-Soll Model for Wave Equation Analysls: Verincation by Dynamlc Finlte Element Approach*. Proc., Thlrd Canadian Conference on Marlne Geotechnical Englneerlng. St. John's, New Foundland, 1988. pp. $781-776$. 
21. de Sltter. W.R. and Groep. H.B., "Speclal Orssiore Plle Driving Test". Orfshore Technology Conference, May 5-8, 1980. OTC 3828. •

22. Vayverglys, V.... "Soll Response During Plle Drlving". Numerical Methods in Offshore Plling. Instlution of Clrll Enginecrs. London. 1880. pp. 53-58.

23. Roy, M.. Blanchet. R.. Tavenas, F. and La Rochelle. P., "Bchavlour of a Sensltive Clay During Plle Driving". Canadian Cieotechnical Journal. Vol. 18. 1881 , pp. 67-85.

24. Hindy. A. and Novak. M.. "Earthquake Response of Buried Insulated PIpes". ASCE, J. of the Eng. Mechanles Dly.. Voi. 106. Yis. Mlti. December. 1980.

25. Norak, M. and Sheta, M., "Approxlmate Approach to Contact Efrect of Plles". Proc. of Session on Dynamic Response of Plle Foundations: Analytical ASpects, ASCE Natlonal Convention. Florlda. Oct 1980. pp. 53-79.

26. Veletsos, A.S. and Verblc, A.. Mibration of Viscoctastic Foundatlons". Earthquake Engineering and Structural Dy namles. Vol 2. 1973. pp. 87-102.

27. Bossard, A. and Cote, J.F., "Analysls of Plle Response to Impact Loading and lse of Statle Soll-Plle Interaction Laws". Second International Conference on the Application of Stress Wave Theory on Plles. Stockholm. Sweden. May 1984.

28. Randolph. M.F. and SImons. H.A.. "An Improved Soll Mlodel for One Dimenslonal Plle Driving Analysis". Third International Conference. Numerlcal Methods in Offshore Plling. Nantes. France. May 21-22. 1986. pp. 3-17.

29. Corte, J.F. and Lepert. P.. "Lateral Resistance During Drfing and Dynamle Plle Testing". Thlrd International Conference, Numericar Methods in Orrshore Plling. Nantes, France, May 21-22, 1886. pp. 19-33.

30. Rausche, F.. Moses, F. and Goble, G.G.. "Soll Reststance Predictions from Plle Dynamics". J: of the Soll Mechanles and Foundatlon Dir.. ASCE. Vol. 88. o. S.M8. Sept. 1872.

31. Rausche F., "Stress Wave Measuring In Practlce". Theme Lecture 
and Paper for Second International Conference on the Application of Stress Wave Theory on Plles. Stockholm. Sweden, May 1984.

\section{$\checkmark$}

32. de Sltter. W.R.. "Measurement of Local Frlction During Drhing". Second Intertiational Conference on the Appllcation of Stress Wave Theory on Plles, Stockholm. Sweden, Mlay 1984, pp. 25-32.

33. Smlth. 1..1.. To. P. and Willson, S.M.. "Plugging of Ripe Plles". Third International Conference. Numerlcal Methods in Ossnore Plling. Nantes. France. May 21-22. 1986, pp. 53-73.

34. Luco, J.E., HadJlan, A.H. and Bos, H.D.. "The Dynamic Mlodellng of the half Plane by Flnite Elements". Nuclear Englneering and Design. Vol. 31, 1974 .

35. Ly'smer. J. and Kuhlemeyer. R.L.. "FInlte Dynamlc Model for Innnite Medla", J. of the Englneerlng Mechanles Dlv., ASCE. August, 1989.

36. Kuhlemeyer, R.L., "Vertical ITbration of Footings Embedded in Layered Media". Ph.D. Thesls, Inlverslty of Callfornla, Berkeley. Callfornla.

\section{3}

37. White. W.. Valliappan. S. and Lee. I.K.. "Lnined Boundary for Finlte Dynamlc Models". J. of the Englneerlng Mech. Dli.. ASCF. pp. 849-864, Oct., $187 \%$.

38. White, W.. Valliappan. S. and Lee. I.K., "Energy Absorblng Boundary for Anlsotrople Materlal". Numerlcal Methods in Geomechanlcs.

38. Lysmer, J. and Drake, L.A.: "A Finlte Element Method for Selsmology". Methods in Computatlonal Physlcs, Vol. 11. Bolt. B. (Editor). Academic Press. Vien York.

40. Kausel. E.. Roesset, J.A. and Haas, G., "Dynamle Analy'sti of Footings on Layered Medla". J. of the Englneering Mechanles DH.. Vol. 101. No. E.M5. Oct. 1875. pp. 679-683.

41. Wass. G.. Riggs. H.R. and Werkle. H.. "DJsplacement Solutions for Dynamic Loads in Transversely Isotrople Stratined Media". Earthquake Engineeing and Structural Dynamles. Vol. 13. 1985. pp. 173-183.

- 42. Veletsos. A.S. and Dotson. K.. "Impedances of Soll Layer with Dlsturbed Boundary Zọne". J. of Geotechnical EngIneenng. Vol. 112. No. 3. March, 1986. pp. 383-368. 

54. Zlenklewtcz, O.C.. Best. B.. Dullage. C. and Stagg, K.6.. "Analysis of . Von-Linear Problems in Rock Mechanles with Particular Reference to Jolnted Rock Systems". Proc., Second Congress of the International Soclety for Rock Mechanics. Belgrade, $19 \pi 0$.

55. Ghaboussl. J.. Wilson. E.L. and Isenberg. J.. "Finlte Element for Rock Jolnts and Interfaces". J. of the Soll Mechanles and Foundation DIvislon. ASCE. Vol. 89. No. S.M110. October, 19i3. pp. 833-848.

56. Tokl. K.. Sato. T. and Mllura, F.. "Separation and Sllding Between Soll and Structure During Strong Ground Motlon". Earthquake Engineering and Structural Dynamles, Vol: 14, 1986, pp. 1-18.

57. Desal, C.S.. "Behavlour or Interfaces Between Stractural and Geologlc Medla": International Conference on Recent Advances In Geotechnical Earthquake Englneering And Soll Dynamles. St. Loul. Mo., 1981, pp.619-638.

58. Desal. C.S.,"Modelling and Implementation of Constitutive Behavlour of Interfaces". International Symposium on Dynamic Soll Structure Interactlon, MInneapolis. Sept. 1884. pp. 103-111.

59. Drumm, E.C. and Desal, C.S.. "Determination of Parameters for a Model for the Cycllc Behavlour of Interfaces", Earthquake Engineering and Structural Dynamles, Vol. 14, pp. 1-18.

60. Drumm, E.C. and Desal, C.S.. "Sand Concrete Interfaces: Cycllc Laboratory Testing and a Constliutive Model". International Symposlum on Dynamlc Soll Structure Interaction, Minneapolls, Sept. 1984, pp. 125-132.

61. Zaman, Mi., Desal, C.S. and Drumm. E.C.. "Interface Model for Dynamlc Soll Structure Interaction". ASCE. J. of Geotechnical Englneenng, Vol. 110. No. 9, 1984, pp. 1257-1273.

62. Herrmann, L.R.. "Finlte Element Analysis In Contact Problems", J. of the Englneerlng Mechanles DIvislon, ASCE, Vol. 104. No, EM5, 1978, pp. 1043-1057.

63. Zlenklewlcz. O.C.. Valliapan. S. and KIng. I.P., "Elasto-Plastlc Solutions of Englneering Problems 'Inltlal Stress'. Finlte Element Approach". Interpational Journal for Numerlcal Methods in Engineering. Vol. 1, 1969, pp.75-100. 
64. Clough, R.I1. and Penzlen. J.. "Dynamles of Structres". McGraw Hill Book Company. 1975.

65. Kagawa. T.. "Soll-Plle Interactlon of Offshore Structures During an Earthquake". Twelvth Annual Offshore Technology" Conference. Houston. Texas. May 5-8, 1880, OTC 3820.

68. Nogaml. T. et al., "Effect of Radlation Damplng on Earthquake Response of Plle Supported Offshore Platforms". Earthquake Englneering and Siractural Dynamics. Vol. 11. 337-353 (1983).

67. Penzlen, J.. "Structural Dynamics of Flxed Orfshore Structures". Behavlour of Offshore Siructures. POSS 76. The Norweglan Institute of Technologi:

68. Wolf. J.P.. "Dynamlc Soll-Structure Interaction". Prentlce-Hall. Inc., 1985.

69. Focht. J.A.. Jr. and Kraft, L.M.. Jr., "Axlal Performance and Capacity of Plles". Chapter 21 in "Planning and Design of Fixed Offshore Platforms". Mfclleland.B. and Relfel, M.D.. (Editors), 1986. Van Nostrand Relnhold Company.

70. Kriger, G.A.: "Modeling of Plled Foundations". Twelvth Annual Orfshore Technológy Conference, Houston, Texas. May 5-8. 1980. OTC 3748.

71. Melth. R.M.. "Force .Coupled Structure Foundation Interaction". J. of Waterway. Port. Coastal and Ocean Englneering. Vol. 110, No. 2. .May, 1984.

72. Taylor. R.E. and RaJagopalan.A.. "Load Spectra' for Slender Offshore Structures In Waves and Currents". Earthquake Englneering and Structural Dynamles, Vol. 11, 1883. pp. 83i-842.

73. Angelldes, D.C.. "Stochastlc Response of Flxed Orfshore Structures in Random Seas", Ph.D. Thesis, Massachusetts Institute gr Tèchnology. Department of Clvil Englneering. Cambridge, Massachusetts.

74. Clausen. C.J.F.. Aas. P.M. and Almeland, I.B., "Analysls of the Plle Foundation System for a North Sea Drilling Plattorm". Proc. of the Third International Conference., Behavlour of Offshore Structures. MIIT, Cambridge, Massachusetts. 
75. Randolph. M.F. and Poulos, H.G.. "Estimating the Flexibility of Orfshore Plle Groups". Proceedings of the Second Internationat Conference on Numerlcal Methods ia Ofrshose Plling. Intrersity of Texas, Austln, Texas, 1982, pp. 313-328.

70. O.Nelll. M.W.. Ghazzaly.O.I. and Ha. H.B.. "Analysls of Three Dimensional Plle Groups with .ion-linear Soll Response and Pile-SollPile Interaction". Ninth Annuat Offshore Technology Conference. Houston. Texas. May 2-5. 1977. OTC 2838.

77. Harlharan. M. and Kumarasamy. K.. "Analysis of Plle Ciroups Subjected to Lateral Loads". Proc. of the Third Internatimal Conference, Behavlour of Offshore Structures (BOSS). MIT. Cambrldge, Massachusetts, pp. 383-390.

78. Anagnostopoulos.'S.A.. "Plle Foundation Modelling for Inelasile Earthquake Analysls of Large Structures". Englneering Siructures. Vol. 5. July, 1983.

78. Angelldes, D., ? and Roesset, J. "Nonlloear Dynamic Stirfness of Plles". Mass chusetts Instltute of Technologj. Department of Civill Englneerind Research Report R 80-13. April. 1980.

80. Poulos. H.G. and Randolph. M.K., "Plle Group Anabssls: A Study of Two Methods". J. Geotechnlcal Englneering. Vol. 109, 1983, pp. 355-372.

81. Nogaml. T. and Pqulson, S.K.. "Transfer, Matrlx Approach for Nonllnear Plle Group Response Analysis". J. Numerical and Analytical Methods In Geomechanlcs. Vol. 9. 1985. pp. 299-316.

82. Penzlen. J.. "Scherney. C.F. and Parmalee. R.A.. "Selsmlc Analysls of Bridges on Long Plles", J. of the Englneering Mechanlcs DIvision. Proc. of the ASCE. Vol. 90, No. EM3, June, 1964, pp. 223-253.

83. Penzlen. J.. "Soll-Plle Interaction". Chapter 14 in Earthquake Englneering. Welgel, R.L. (Editor), Prentice-Hall, 1870.

84. Llou. D.D. and Penzlen, J., "Mathematleal Modelling of Plled Foundatlons". Numerical Methods in Orfshore PIllng. ICE, London. 1980, pp. 69-74.

85. Matlock et al. "SImulation of Lateral Plle Behavlour Inder Earthquake Loading". Proc. ASCE. Speclalty Conference on 
- Larthquahe Englneerlng and Soll Dynamirs. Pasalfena. Callfornla. 1978. ot. $800-619$ I

86. Tallml, H.." Dynamle Analysls of a Strucure Erabedded in an Elasile Medlum". Proc of the Fourth Horid" Conference on Earthquake Engineering. Chile. 1969.

87. Nogaml. T. and Novak. M. "Soll-Plle Interaction in Vertlcal Vibration". International $\$$.. Earthquake Engineering and soil Dynamics, 1977. No. 3. pp. 249-261.

88. Novak. M. and Togamt. T.. "Soll-Plle Interaction in Horlzonta! Vibration". Earthquake Englneering and Structúral Dinamics. Vol. 5, 1975. pp. 263-281.

89. Norak.M., "Dynamic Stiffness and Damping of Plles". Canadian Geotechnical Journal. Vol. 11. No.4. 1974. pp. 5i4-598.

90. Koborl. T. et al., "Dy namle Behaviour of a Laterally Loaded Plle". Proc.. Ninth Internatlonal Conference on Soll Mechanles. Tokyo. 1977.

91. Kuhlemeyer, R.L.. "Vertical Vibration of Piles". J. of the Geotechnlcal Englneerlng Dlvislon. ASCE. Vol. 105. No. GT2. pp. 371-388.

- 92. Kuhlemeyer, R.L., "Statlc and Dynamic Laterally Loaded Floating Plles". J. Geotechnical Englneering DIvislon, ASCE, Vol. 105.: io. GT2, 1979.

)

93. Blaney, G.W., Kausel, E. and Roesset. J.M.. "Dynamlc Stiffness of Piles". Proc. Second Intertional Conference on Numerlcal Methodş in Geomechanles, ASCE, New York, 1976. pp. 1001-1012.

84. Angelides, D.C. and Roesset, J.M. "Nonllnear Lateral Dynamlc Stirfness of Plles". J. of the Geotechnical Englneerlng Divislon. Proc. ASCE, Vol. 107. No. GT11. Nov., 1981, pp. 1443-1458.

95. BanerJee. P.K. and Butterneld. R.. -Boundary Element Methods in Geomechanjlcs". Chapter 10 in Finlte. Elements In Geomechanics. Willey, 1977.

96. Baranov. V.A.. "On the Vibration of an Embedded Foundation". (In Russlan), Voprosy, Dinamikl i Prochnostl, No. 14, Polytechnical Instltute of RIga, 1967: pp. 195-209. 
97. Novak. M.. "Vertleal Itbration of Floating Plles". J. of the Eng Mech. Division; ASCE. Vol. 103. o. 103. No. Ell1. Feb., 19:7. pp.153-168.

98. Norak. M. and Aboul Ella. F.. "Impedance Funcilons of Plles in Layered Medla". J. of the Eng. Mech. Divislor. ASCE. Vol. 104. No E.M16, June, 1978. pp. 843-681.

99. Kausel. E.. Forced Vtbration of Clrcular Fouxdation on Labered Media". Research Report Ri4-11, Clwhl Englneering Dept. MIIT. Jan. $1974^{-}$

100. Sallnero. I.S. and Roesset, J.M.. "Comparison of Analytica: Methodto Evaluate Axlal and Lateral Dynamic Surfness of Single Plles". Elghth European Conference on Earthquake Englneerlng. Llsbon. 1988.

101. Novak, M., Aboul Ella, F. and Sheta, M., "Pll.Al2-A". Computer Program for Calculation or Stiffness and Damping of Plles in Layered Medlä, The Unverslty of Hestern Ontarlo, S.ACD.A. Lndon. Ontario. Canada.

102. El-Sharnouby, B. and Novak, M.. "Statle and Low Frequen" Response or Plle Groups". Canadian. Geotechnical Journal. Visl. 22. No. 1, pp. 79-94.

103. Kaynla. A.M. and Kausel. E.. "Dynamle Behavlour of Plle Grouvis". Conference on Numerlcal Methods in Offshore Pling. Iniversity of Texas, Austin. Texas, pp. 509-532.

104 Poulos, H.G., "Analysls and Settlement of Plle Groups". Geotechnlque, Vol. 18. pp. 448-471. 1868.

105. Poulos. H.G., "Behavlour of Laterally Loaded Plles -2- Plle Groups". J. Soll Mech. and Foundation Division. Proc. of ASCE. 1971.

100. Poutos, H.G., "Group Factor of Plle Dellection Estimation". J. Geotechnical Eng. Div., ASCE, GT12. 1979. pp.1489-1509.

107. Butterneld. R. and Banerjee, P.K., The Problem of Plle Group Plle Cap Interactlon ". Geotechnlque, Vol. 21, No.2, 1971, pp. 135-142.

108, Wolf, J.P. and Von Arx. G.A.. "Impedance Functlons of a Group of Vertlcal Plles". Proc. ASCE Speclalty Conference on Eartiquake Eng. and Soll Dynamles, Pasadena. Callfornla, 1978, pp. 1024-1041. .. 
109. Wolf. J.P., Dynamic Sumness of Group of Battered Plles". J. Geotech. Eng. Dlvislon. ASCE. Vol. 108. No. GT2. pp. 198-203. Feb., 1980.

110. Nogaml. T., "Dynamle Group Efrects of Muliple Plles Lnder Verilca: VIbration". ASCE. Eng. Mfech. Spec. Conference. Austin. Texas. 1979. pp. 730.754.

111. Nogaml. T.. Dynamle Stimness and Damping of Plle Groups in Inhomogeneous Soll. "Proc. of Sesston on Dinamic Respunse of Plite Foundations: Aralytlcal Aspects, ASCE Matlona! Convention. $O:$ : 1880. PP..31-52.

112. Sheta. M. and Novak. M., "Vertlcal Vibration of Plle Giolips" J. Geotechnical Eng. Dlvislon. ASCE, Vol. 108. No. GT4. Aprll. 198:., pp. $570-590$.

113. El-Sharnouby. B.. "Statle and Dynamle Analysls or Pile Foundailuna". Ph.D. Thesis, Lniversly of Western Ontarlo. London. Canada. 1984.

114. Novak. M. and El-Sharnouby, B., Plle Groups Lnder Statle and Dynamic Loading". Proc. "Of the Eleventh Internationa! Conference on Soll Mechanles and Foundation Englneering. San Franclseo, 1985. Vol. 3. pp. 1448-1454.

115. Prlvate communlcations With Wotton. R.L.. Aikin Researin and Development, L'.K.

116. Prliate communtcations wlth Houell. J.F.. Mlipar. Ausiralla. .

117. Norak, M., "Soll-Plle Interartion Inder Dynamic Loading". Numerlcal Methods in Ofrshore Plling. Instltution of Chll Enginerers. London. 1880. pp. 59-68.

118. Forrlstall, G.Z.. Ward. E.G.. Cardone. V.J. and Borgman. L.E.. "Thm Directional Spectra and Kinematles of Surface Girally Wases in Troplcal Storm Della". J. of Physlcal Oceanography. 1'8. 19i8. ph 888-909.

119. Lamb. H., "Hydrodynamlcs". Slxth ed.. Dover. Yen York. 1945.

120. Phlljps. O.M., "The Dynamics of Lpper Ocean". Second ed. Càmbridge Lniv. Press. 1977. 
121. Minkenberg. H.L. and Gle. T.S.. "WIII The Regular Wave Concept Jeld Meanlngful Motlon Predlctions for Orrshore Structures". Slxih Annual Ortshore Technology Confereence. Houston. Texas, May 1974. OTC 75200 .

122. Wheeler, J.D.. -Method for Calculating Forces Produced by Irregular Wives". Flrst Annual Onshore Technology Conference. Houston. Texas. Mry 1969. OTC 1008.

123. Lambrakos. K.F. and Brannon. H.R.. Wave Force Calculactons fo: Stokes and tion Stokes Waves". Proc. Slxth Annual Ofrshore Technology Conference. Houston. Texas. 1974. OTC 2039

124. Dean. R.G.. "Stream Function Representation of Nonlinear Ocear. Waves". J. Geophystcal Research, V. 70. pp 4561-4572. i

125. Morlson, J.R., O'Brien. M.P., Johnson, J.W. and Schaar. S.A.. "The Force Exerted by Surface Waves on Plles ${ }^{*}$. Petroleum Transactions. AJME. Vol. 188. 1850. pp. 149-154.

126. Horben. X.. Miller, B.L.. Searle, J.H. and Ward. G., Estimation of Fluld Loading on Otrshore Structures". Proc.. Instltution of C'Wll Engineers. Part 2. Vol. 63, Sept. 1977. pp. 515-562.

127. Wiegel, R.L., Beebe, K.E. and Moon, J., Ocean Wave Forces on Clrcular Cylindrical Plles". Journal of Hydraulles Divislon. ASCE: vol. 83. HY2, Aprll, 1957, Dp. (1192-1)-(119936).

128, Keulegan, G.H. and Carpencer, L.H., Forces on Cyllnders and Places In an Osclllating Fluld". J. Res. Nat. Bureau of Siandards. Vol 60 . 1958. No. 5. May. pp. 423-440.

129. Sarpkaya. T.. -In-Line and Tranverse Forces on Cyllnders in - Osclllatory Flow at High Reynolds Number", Orfshore Technolog Conference, 1976, OTC 2533.

130. Evans, D.J., 'Analysls of Wave Force Data". O.T.C.. 1969, Vol. 1. Paper OTC 1005, pp. (1.51)-(1-70).

131. Borgman. L.E., "Statlstlcal Models for Ocean Waves and 11 as" Forces". Advancés in Hydrosclence, Vol. 8. 1972, pp. 139-181

132. Borgman, L.E., "Ocean Wave SImulation for Englneering Design". J. of the Waterways and Harbours DIv.. Proc.. ASCE, Vol. 95. No. WW 4. Nor. 1869, pp.557-583. 
133. Malhotra. A. and Penzlen, J., "Non-determinlstle Analysls of Orrshure Structures". J. Eng. Mech Dlv.. ASCE. Vol. 96. No. Ell6. Dec. 1970. pP. 985-1003.

134. Mllisuyasu, H., Tasal. F.. Suhara, T., Mlizuno, S.. Ohkusu. M.. Honda. T. and Rlkushl, K., Observatons of the Dlrectional Spectrum of Ocean W'aves ('sing a Cloverleaf Buoy*. J. of Physical Oceanography. Vol. 5. Oct. 1875. pp. 750-760.

135. Mllsuyasu. H. and Mllzuno. S.. "Dlrecilonal Specira of Ocean Surface Waves". Fifteenth Coastal Englneerlng Conference, Vancouver, 1978.

136. Mobarek. I.E.. "Dlrectlonal Spectra of Laboratory Wind Wares". I of the Waterways and Harbors Dir., ASCE. Vol. 81. No WW3. Aug. 1965. pp. 91-118.

137. Dean. R.G. and Borgman, L.E., "Wind and Wave Forces". Chapter 12. Planning and Design of Fixed Ortshore Structures. Mclelland.B. and Relfel. M.D. (Editors). 1986. Van Vostrand Relnhold Company.

138. Dean, R.G., "Hybrld Methods of Compuling Wave Loading". Pror. Orfshore Technology Conference. Houston. May 1877. OTC 3029. pp. 483-492.

139. Borgman, L.E.. "Spectral Analysls of Ocean Wave Forces on Plling". J. of the Waterways and Horbors Dlv.. Proc. of the ASCE. Vol. 93. No. WW2. May 1967.

140. Burrows. R.. Probabllistlc Description of the Response of Offshore Structures to Random Wave Loading". In Mechanles of Wave Forces on Cyllnders. Edlted by Shaw. T.L.. Pltman. London. 1979, pp. 577-595.

14. Zedan, M.F., Yeung. J.Y., Salena, H.J. and Flscher, F.J., 'Dynamle Response of a Canillever Plle to Vortex Shedding In Regular Waves", Twelvth Annual Ortshore Technology Conference, Houston. Texas. May 1980.OTC 3790.

142. Sarpkaya. T. and lsaacsoh. M.. Mechanlcs of Wave Forces on Ofrshore Structures". Chapter 4. Van Mostrand Relnhold Co.. 1981.

143. Berge. B. and Penzlen. J.. -Three DImenslonal Stochastlc Response of Offshore Towers to Wave Forces". Ortshore Technology Cunference. .May 19i4. OTC 2050. pp.173-183. 
144. Foster. E.T.. "Model for Nonllnear Dynamics of Onshore Towers". J. Ene. Mech. DIV. Proc., ASCE. Vol. 96. No. Elll, Feb. 19:0. DF. $41-67$.

145. Wu. S.C. and Tung. C.C. "Random Response of Offshore Structures to Wave and Current Forces". Sea Grant Publlcation C.C.S-SG-75-2:2. Vorth Carollna State Inlverslty. Rajelgh. N.C.

146. Rice. S.O., "Mathematical Analysts of Random Molse". Beil Sy=tem Tech. J. . Vol. 23. pp. 282-332. Vol. 24. pp. 46-156.

147. Longuet-Higgins, M.S. and Barber. N.F.. "Four Theoretla! Notes on the Estimation of Sea Conditions", Report. Admiralty. Res. Lab.. Teddington.

148. StDenis. M. and Plerson. W.J.. 'On the Motlon of Shlps in Confused Seas". Trans. Soc. Naval Archltects and Marine Eng!neers. Neh York. 1861. pp.280-357.

149. Plerson, W.J., "Wind Generated Gravlty Waves", Advances in Geophysics. Vol. 2. 1955. pp. 93-178.

150. Neumann. G. and Plerson. W.J.. Chapter 12. Princlples of Phystcal Oceanography. Prentice -Hall Inc., 1968.

151. Kinsman, B.. "Wind Waves, Their Generation and Propagation on the Ocean Surface". Prentlce-Hall Inc.. 1985.

152. Miltsuyasu. H.: "Recent Studles on Ocean Wave Spectra". ILTAHI. 1985. Elsevler Sclence Publlshers B.I.

153. Darbyshire, J.. "The Generation of Waves by Wind". Proc.. Roya! Soclety. Serles A. Vol. 215 . pp. 299-328.

154. Neumann. G.. -On Ocean Wave Spectra and a New Method of Forecasting Wind Generated Sea". L.S. Army Corps of Englneers. Beach Erosion Board. Tech. Memo No. 43.

155. Plerson, W.J. and Moskowitz. L.. "A Proposed Spectral Form for Fully Developed Wind Seas Based on the Sirnllarlty Theory of S.A. Kitalgorodjkll". J. of Geophyslcal Research. Vol. 69, Yo. 24. Dec. 15. 1964.

158. Bretschnelder. C.L.. -Wave Varlabllity and Wave Spectra for Wind 
Generated Gravlty Waves". L's Army Corps of Englneers. Berart: Eroston Board. Tech. Memo. No 118.

157. Hasselmann, $k$. et. al. "Measurement of Wind Wave (irouth and

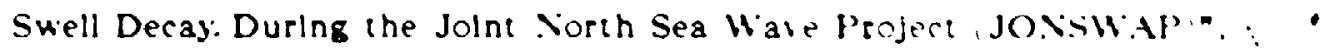
Disch. Hydrogr. 2.. Suppl. A. No. 12. 1973.

158. Ochl, M.K. and Hubble. E.... "Slx Parameter llate Specta". Fifteenth Coastal Englneering Conf., Vancouter, 1976. of 301-328

159. Borgman. L.E.. "Dlrectlonal Spectra Models for Deslgn Lse". Flrs: Annual Orshore Technology Conference. Houston. Texas. Mas 1969. OTC 1089.

160. Longuet-Higgins, M.S., Cartwright, D.E. and Smith. X.D. - Observations of the Directlonal Spectrum of Sea Waves I'sing the Motion of a Floating Buoj". In: Ocean Wave Spectra. Prentice -Hall. pp. 111-132.

161. Berge, B.. -Three Dimenslonal Stochastic Response of Orfshore Towers to Wave Forces". Ph. D. Thesis. Universlty or Callfornia. Berkeley, Callfornla, 1973.

162. Cote, L.J., Davls. J.O., Marks, W., McGough, R.J., Mehr, E., Plerson. W.J., Ropek. J.F.. Stephenson. G. and Vetter. R.C.. "Directional Spectrum of a Wind Generated Sea as Determined From Data Obtalned by the Stereo Wave Obseriation Project". Meteorologleal Papers. Vol. 2. New York Linlverstty. Colleze of Englneering. pp. 1-88.

163. Davenport, A.G., "Wind Structure and Wind Cllmate". Paper presented at the Internatlonal Research Seminar on Safety of Structures Linder Dynamlc Loading. Trondhelm, June 1975.

104. Popov, E.P.. Mahin, S.A. and Clough, R.W.. Inelastlc Response of Tubular Steel Orrshore Towers": J. Structural DIviston. Proc. ASCE. Vol. 111, . Yo. 10. Ocit. 1985. pp. 2240-2258.

165. Sunder. S.S. and Connor, J.J.. "Sensltuvlty Analysls for Steel Jacket Orfshore Structures". Progress in Englneering Sclences. Vol. 1. Djnamle Analysis of Orfshore Structures. KIrk. C.L. (Edlior) CMIL Publlacatlons. 1982.

168. Angelldes. D.G. and Connor. J.J.. "A Probabllisttc Model for the Stiffness Degradation of Steel Jacket Structures". Proc. Second 
Internatlonal Canference. Behavlour of Orfshore Structures, London. 1979.

167. Penzlen, J. and Kaul. M.K.. "Response or Orrshore Touers to situen Motion Earthquakes". Earthquake Englneering and siructura! Dynamles. Vol. 1. 19:2, pp. 55-68.

168. Penzlen. J. Kaul. Mik. and Berge. B.. "Stochastli Responne" of Orrshore Towers to Random Sea liaves and strong Morion Earthquakes". Computers and Structures. Vol. 2. 1972. pp. 733.7.jo

169. Weaver. W.J. and Gere, J.M., Matrlx Analysle of Frament Structures". D. Van Nostrand Company. 1980.

170. Archer, J.S., "Conslstent Mass Matrlx for Distrlbuted Mass Sirstems". J. Structural Division. ASCE. Vol. 89. No. ST4, 1983, pp. 161-178.

171. Cook. R.D.. "Concepts and Applications of Finlte Element Analysls". John Willey. 1974.

172. Kolousek. V.. "DYhtianlcs In Englneerlng Structures". Halsted Press. Division of J. Willey, 1873.

173. Cralg. R.R., "Structural Dynamics: An Ihtróduction to Computer Methods". John Willey, 1981.

174. Rublnstlen, M.F.. "Matrlx Computer Methods In Structural Analysls". Prentlce-Hall. Inc., 1086.

175. Godeau, A.J. and Deleull. G.E., "Dynamlc Response and Fallgue Analysls of Fixed Orrshore Structures". Annual .Ortshore Technology Conference, Houston, Texas, . OTC 2260.

170. Taylor. R.E. and Rajagopalan. A.. "Dynamles of Offshore Structures. Part 1. Perturbation Anajysls". J. Sound and tibration. Vol. 83, 1982. pp. $401-416$.

177. Rajagopalan. A. and Taylor. R.E., "Dynamles of Ortshore Structures. Part 2: Stochastic Averaging Analysls". J. Sound and Vibration. Vol. 83. 1982, pp. 417-431.

- 178. Frazer, R.A., Duncan, W.J. and Collar. A.R., "Elementary Matrlces". Cambridge Lniverstty Press, London. 1946. 
179. Plpes. L.A. and Horanessian. S.A.. "Matrix Computer Methods in Engineeing*. John Willey. 1969.

180. El-Hirnaky. L.. "Soll-Structure Interaction Inder Dynamle Loads". Ph.D. Thesls. The Unlversty of Western Ontarlo, London. Canada. 1984 .

181. Norak. M. and El-Hifnauy. L.. "Effect of Soll-Structure Interaction on Damplng of Structures". J. Earthquske Englneerlng and Structural Dynamics, Vol. 11. pp. 595-621.

182. Tralll-Nash. R.W.. "Modal Methods In the Dynamics of Systems With Con-Classical Damplng". Earthquake Englneering and Structural L) namles. Vol. 8. pp. 153-169. 1981.

183. Dahson. T.H.. "Offshore Structural Englneering". Prentlce-Hall, Inc.. 1983. 
Appendix A

Stiffness Matrix of Rectangular Axisymmetric Element

The stiffness matrix of the rectangular axisymmetrle element shown in fig

4.5 was rederlved from nest pitnclples and is given herein.

A.1. Some Basic Constants

$$
\begin{aligned}
& C 11=E(1-\nu) /(1+\nu)(1) \\
& C 12=\nu E_{1}(1+\nu)(1-2 \nu \\
& C 44=E / i_{1}(1-\nu ! \\
& B 3 A=h \\
& B 5 B=r_{j}^{2} \ln \left(r_{j} / r_{1}\right)-2\left(r_{j}^{2}-r_{i} r_{j}\right)+\left(r_{j}^{2}-r_{i}^{2}\right), 2
\end{aligned}
$$

where $r$, and $r$, are the outer and inner radit of the element. respecthely. $h$ ts the element height and $E$ and $\nu$ are the Young's modulus and Poison's rath of the material. respectively.

2.54 
255

$$
\begin{aligned}
& B \otimes B=r_{1}^{2} \ln \left(r_{j} / r_{1}\right)+2\left(r_{1}^{2}-r_{j}\right)+\left(r_{j}^{2}-r_{1}^{2}\right) / 2 \\
& B 13 B=r_{1} r_{j} \ln \left(r_{j} r_{1}\right)-\left(r_{2}^{2}-r_{2}^{2}\right) / 2 \\
& B 1 B=h^{3} ; 3 \\
& B 10 . A=-h^{2} / 2 \\
& B i . A=\left(r^{2},-r_{i}^{2}\right) / 2 \\
& B 3 B=r_{j}^{4} / 12-\left(r_{j} z_{i}^{2} / 2+2 r_{j}^{3} / 3-r_{i}^{4} / 4\right. \\
& B_{4} B=r_{j}^{4} / 4+\left(r_{i} r_{j}^{2} / 2-2 r_{i} r^{3} / 3-r_{i}^{1} / 12\right. \\
& B 10 B=-i\left(r^{3},-r_{3}^{2} r_{j}\right) / 2-\left(r^{3},-r_{i}^{3}\right) / 3^{\prime} \\
& B 11 B=\left(r^{4},-r_{i}^{4}\right), 12+\left(r_{1}^{3},,-r_{1} r^{3}\right), 6 \\
& B 12 B=-\left(r^{3},-r_{z}^{3}\right) / \theta+\left(r_{1} r_{j}^{2}-r_{1}^{2} r_{j}\right) / 2 \\
& B 17 B=-i\left(r_{i} r^{2},-r_{1}^{3}\right) / 2-\left(r^{3},-r_{1}^{3}\right) / 3 \\
& B 23.4=\left(r,-r_{1}\right)^{2} / 2
\end{aligned}
$$

A.2. Terms of the Upper Half of the Stiffness Matrix 


$$
\begin{aligned}
& K(1.1)=\{((B 1 A+B 5 B) C 11-2 \quad B 23 . A \quad C 12\} B 1 B+B 3 . A \quad B 3 B \quad C 44\} \\
& K(1.2)=\left(B 10 B\left(C_{44}+C_{12}\right)-2 \quad B 12 B \quad C_{12} ; B_{10.4}\right. \\
& K(1.3)=i(B 5 B+B 1 . A) C 11 / 2-B 23.4 \quad C 12 ; B 1 B-B 3.4 \quad B 3 B \quad C 44 \\
& K(1.4)=\left[\begin{array}{lll}
2 & B 12 B & C_{12}+B 10 B\left(C_{44}-C_{12}\right)
\end{array} B_{10 . A}\right. \\
& K(1.5)=((-B 13 B-B 1 . A) B 1 B C 11 / 2-B 3 . A B 11 B C 44) \\
& K(1,6)=[(B 12 B+B 17 B) C 12-B 10 B \quad C 44 ; B 10 A \\
& K(1.7)=(-B 13 B-B 1 . A) B 1 B C 11+B 3.4 \quad B 11 B C 44 \\
& K^{\prime}(1.8)=\left(\left(-B_{12} B-B_{1} ; B\right) C 12-B 10 B \quad C_{44} B 10.4\right. \\
& h^{\circ}(2,2)=\left(B 3.4 \quad B 3 B C_{11}+B 1 A \quad B 1 B \quad C_{44}\right) \\
& K(2,3)=-K(1,4) \\
& K(2,4)=(-B 3.4 \quad B 3 B C 11+B 1 A \quad B 1 B \quad C 44 / 2) \\
& k(2,5)=((-B 12 B-B 10 B) C 12+B 17 B \quad C 44) B 10.4 \\
& K^{\prime \prime 2,6)}=\left(\begin{array}{lllll}
-B 3.4 & B 11 B & C 11-B 1 A & B 1 B & C_{44} / 2
\end{array}\right) \\
& K(2.7)=\left[\left(-B_{12} B-B 10 B\right) C 12-B 17 B \quad C 44 ; B 10.4\right. \\
& K(2,8)=(B 3.4 . B 11 B, C 11-B 1 . A B 1 B(44) \\
& K(3.3)=K(1.1) \quad K(3.4)=-K(1.2) \\
& K(3.5)=((-B 1 . A-B 13 B) B 1 B C 11+B 3.4 \quad B 11 B \quad C 44 \\
& \text { - } K(3.6)=-K(1.8), \quad K(3.7)=K(1.5) \\
& K(3.8)=-K(1,6) \quad K(4,4)=K(2.2) \\
& \text { - } K(4.5)^{\circ}=-K^{\circ}(2.7) \quad K(4.6)=K(2.8) \\
& K(4,7)=-K(2,5) \quad \dot{K}(4,8)=K(2,8)
\end{aligned}
$$




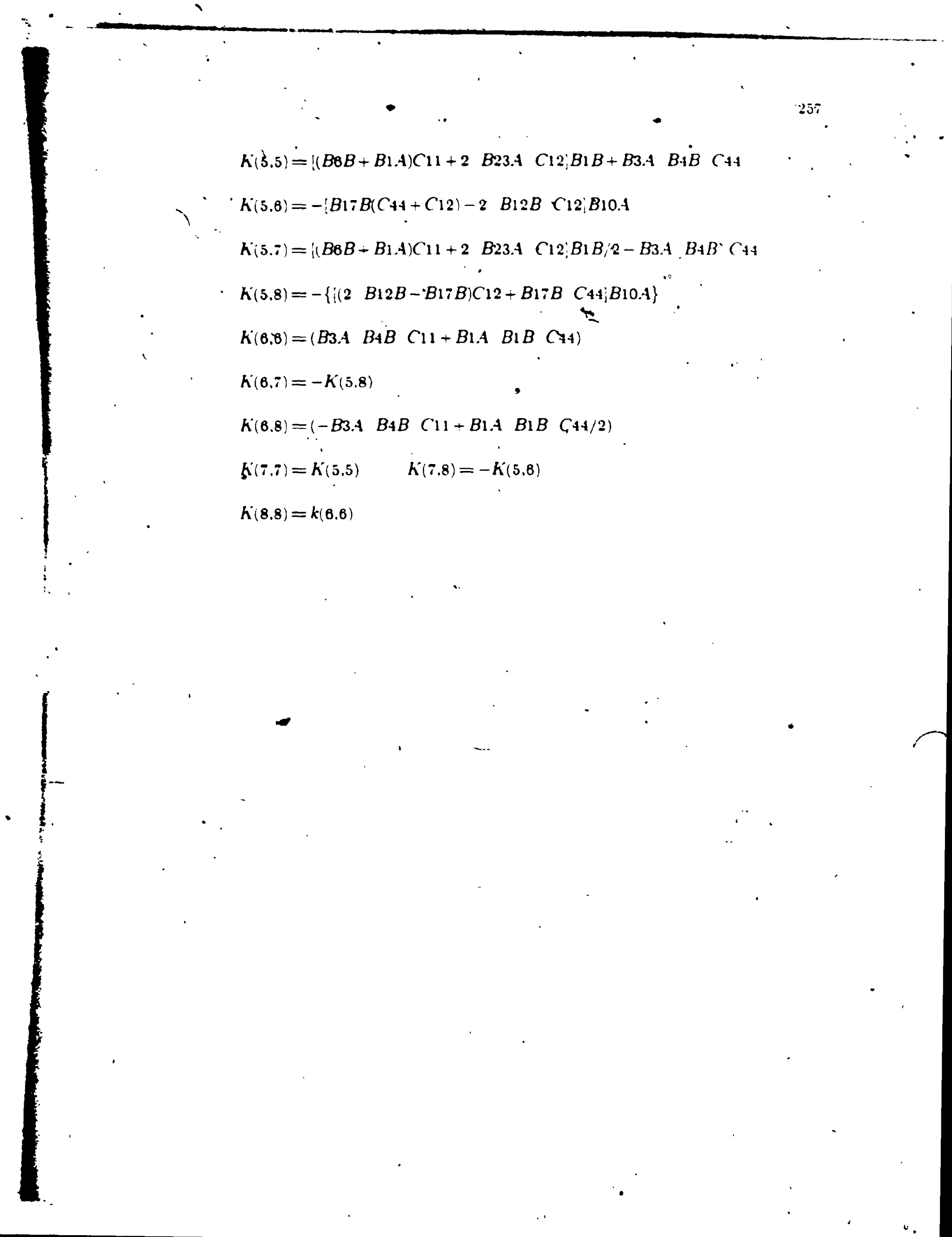




\section{Appendix B \\ Wave Forces for Directional Spectrum Model}

- The cross spectra of nodal wave forces, $S_{p_{2} p_{m}}(\nu)$, could be evaluated once the Integrals $I_{k l}$ in Eq. 6.62 are carrled out. On substltuting by Eqs. 6.83 and 6.39 In Eq. 6.62. the Integrals $I_{k l}$ are glven by

$$
\begin{aligned}
I_{k I_{1}}= & e_{1} e_{2} \frac{\varsigma}{4 \kappa^{2}} \int_{-\pi}^{\pi} G(\omega, \theta) C 1(\theta) C 2(\theta) \cdot I_{n s} \\
& \cdot\left(I_{1}+n 1 I_{2}\right)\left(I_{3}+n 2 I_{4}\right) d \theta
\end{aligned}
$$

where in $I_{k_{1} l_{2}}, k$ and $l$ refer to members $k$ and $l$ respectively whlle 1 and 2 refer to the directions of water particle velocitles associated with these members. For example, $I_{k^{\prime} y}$ is the Integral of the cross spectrum of water partlele veloclty in direction $x$ on member $k$ and the water partlcle velocity in direction $y$ on member l. In Eq. B.1.

$$
\begin{aligned}
& e_{1}= \begin{cases}1 & 1 / / X \text { or } 1 / / Z \\
-i & 1 / / Y\end{cases} \\
& e_{2}= \begin{cases}1 & 2 / / X \text { or } 2 / / Z \\
i & 2 / / Y\end{cases} \\
& n 1= \begin{cases}1 & 1 / / X \text { or } 1 / / Z \\
-1 & 1 / / Y\end{cases} \\
& n 2= \begin{cases}1 & 2 / / X \text { or } 2 / / Z \\
-1 & 2 / / Y \\
5\end{cases} \\
& s=\frac{\sin _{h h^{2}}(2)}{\sinh ^{2} \times D}
\end{aligned}
$$




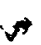<smiles>CCCCCC</smiles>

259

-

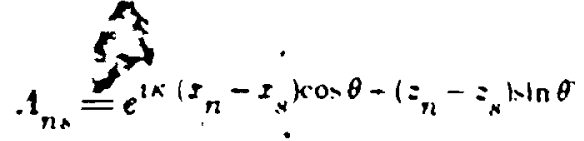

and the direction paramequs $C 1(\theta)$ and $C \xi(\theta)$ are given by

$$
C 1(\theta)= \begin{cases}\operatorname{los} \theta \quad & 1 / 1 X \\ 1 & 1 / / \gamma \\ \sin \theta & 1 / / Z\end{cases}
$$

and

$$
C(\theta)= \begin{cases}\cos \theta \quad ; \quad, & 2 / / \gamma \\ 1 & 2 / / y \\ \sin \theta \quad, & 2 / / Z\end{cases}
$$

The terms $I_{1}$ in Eq. B.1 are given by

$$
I_{1}=e^{\cdot 1} n\left(e^{R_{a k}} \bar{\kappa}^{\bar{\alpha}}-1\right) / R_{\mathrm{ak}}
$$

$i$

$$
\begin{aligned}
& I_{2}=e^{-I_{n}\left(e^{R_{b k}} \bar{x}-1\right) / R_{b k}} \\
& I_{3}=e^{-I_{s}\left(e^{R_{a l} l{ }_{r} \bar{x}}-1\right) / R_{a l}} \\
& I_{1}=e^{-I_{s}\left(e^{R_{b l} l_{r}{ }_{r}}-1\right) / R_{b l}}
\end{aligned}
$$

In Eq. B.10. the terms $R_{a k^{\prime}} R_{b k^{\prime}} R_{a l}$ and $R_{b l}$ are defined by Eq. 6.69 and $A_{n}$ and $A_{\text {a }}$ are given by Eqs. 6.66 and 6.67 , respectively. The directional spread function $G(\omega, \theta)$ in Eq. Blt is the Circular Normal directional distribution given by Eq. 6.18. 
Appendix C

Wave Forces for Unidirectional Waves

model is essentially the unidirectional model where the surface elevation Is represented by Eq. 6.10 and the water particle velocity spectrum is given by Eq. 6.45. 1.e.

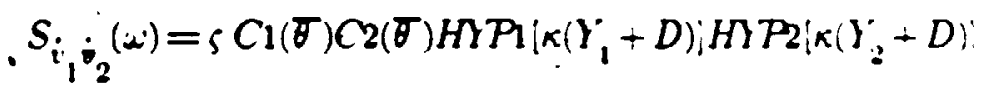

$$
\begin{aligned}
& =\quad \exp \left\{i \kappa\left[\left(I_{1}-I_{2}\right) \cos \bar{\theta}+\left(z_{1}-z_{2}\right) \sin \overline{l_{1}}\right\}\right.
\end{aligned}
$$

where all the terms are dented in Paragraph 6.3.3.1. By expanding the hyp perbollc sin and cos terms and substituting by Eq. 6.63. the Integrations in Eq.

Q.62 are carried out to give

$$
\because \quad I_{k l}=e_{1} e_{2} C 1(\bar{\theta}) C_{2}(\bar{\theta}) \frac{\zeta}{4 \kappa^{2}} A_{n_{k}}\left(I_{1}+n_{1} I_{2}\right)\left(I_{33}+n_{2} I_{1}\right)
$$

$\therefore$ where $e_{1}$ and $e_{2}, n_{1}, n_{2}$ and $s$ are given by Eqs. B.2 to B.6. respectively. $A_{h s}, C_{1}(\bar{\theta})$ and $C_{2}(\bar{\theta})$ are defined by Es. B.7 to B.9. respectively. If $\theta$ is substituted by $\delta$. The terms $I_{i}, i=1 \cdots 4$ are given by Eq. B.10 if $\theta$ is substituted by In the terms $R_{a k^{\circ}} R_{b k^{\circ}} R_{a l}$ and $R_{b l}$. 


\section{Appendix D Wave Forces Assuming Constant Velocity}

When the veloclty is assumed to be constant along the membets. the integrals In Eq. 6.62 are written as

$$
I_{k l}=L_{k} L_{l} S_{r_{n} ;}
$$

where $L_{k}$ and $L_{l}$ are the trlbutary lengths of members $k$ and $/$ respectively. $S_{i_{n}}$;

Is the cross spectrum of water partlcle velocity at nodes nodes $n$ and $s$. By substltuting by the approprlate formulae for the water partlcle veloclty. spectra for different models. the following expresslons are obtalned:

\section{1)Directiond Spectrum Modèl}

$$
\begin{aligned}
& I_{k l}=L_{k} L_{1} e_{1} e_{2}{ }_{2}^{-}\left(e^{1} n+n_{1} e^{-1_{n}}\right)\left(e^{-1}+n_{2} e^{-1_{n}}\right) \\
& \int_{-\pi}^{\pi} G\left(\alpha_{i} \cdot \theta\right) C 1(\theta) C 2(\theta) \exp \left\{2 \pi_{i}^{\prime}\left(x_{n}-I_{s}\right) \cos \theta+\left(z_{n}-z_{s}\right) \sin \theta_{i}\right\}
\end{aligned}
$$

where $e_{1} \cdot e_{8} \cdot n_{1} \cdot n_{2}, g(z), A_{n g} \cdot C l(\bar{\theta})$ and $C_{2}(\bar{\theta})$ ate denned by Eqs. E.2 to E.9. . respectlvely and $A_{n}$ and $A_{s}$ are denned by Eqs. 6.66 and 6.67. respectlvely. $G(\omega, \theta)$ Is the Circular Normal directlonal Zistribution given by Eq. 6.18.

\section{2)Coherence Function Model}

$$
\begin{aligned}
I_{k l}= & L_{k} L_{1} e_{1} e_{2}{ }_{4}^{S} C 1(\theta) \dot{C}(\theta) A_{n s} \Delta_{n s} \\
& \left(e_{1}^{1}{ }_{n}+n_{1} e^{-1_{n}}\right)\left(e^{1_{s}}+n_{2} e^{-1_{s}}\right)
\end{aligned}
$$

where $A_{n s^{\prime}} C_{1}(\bar{\theta})$ and $C_{2}(\bar{\theta})$ are glven by Eqs. B.7 to B.9, respectlvely, if $\theta$ is substltuted by $\pi . \Lambda_{n e}$ ls glven by Eq. E.10.

\section{3)Fully Correlated Unidirectional Model:}

$$
\begin{aligned}
& I_{k l}=L_{k} L_{l} e_{1} e_{2}{ }_{24}^{S} C_{1}(\theta) C_{2}(\theta) A_{n *} \\
& \left(e^{-1} n+n_{1} e^{-d_{n}}\right)\left(e^{1_{n}}+n_{2} e^{-1_{n}}\right)
\end{aligned}
$$

where $A_{n \theta}$ is glven by Eq. B.7 if $\theta$ is substltuted by $\delta$. 


\section{Appendix E \\ Wave Fotces for Coherence Function Mọdel}

Evaluating the Integrals $I_{k l}$ In Eq. 6.62 is necessary to establish the specira! matrlx of nodal forces. When the coherence function representation of the water particle veloclty spectra. expressed by $E q s .6 .46$ and 6.82 . is used. the absolute value terms have to be expanded to be able to carry out the integration- As discussed in Subsection. 6.6.1. 2 dirrerent cases are distingulshed:

\section{A) Nodew $n$ and . Coincide:}

A-1)One pair of the direction cosines have identical signs:

The expanslons of the absolute value terms are glven by Eqs. 6.85106 .87 and carrying out the integrations $I_{k l}$ ylelds

$$
J_{k l}=e_{1} e_{2} \operatorname{Cl}(\theta) C 2(\theta) \frac{\zeta}{4 \kappa^{2}}\left[\sum_{i=1}^{16}(-1)^{n}{ }_{1} I_{1}\right.
$$

where $\sigma$ is the mean direction of advance of the wave system, $\varepsilon_{1}$ and $\epsilon_{2}$ are denned by Eqs. B.2 and B.3, respectlvely, $S$ is glven by Eq. B.6 and $C 1 \theta$, and $C 2(\bar{\theta})$ are defined by Eqs. B.8 and B.8 respectlvely. If $\theta$ is substituted for $\bar{\theta}$. The Integer $n_{1}$ is given by

$$
\begin{aligned}
& n_{1}=\left\{\begin{array}{c}
z+1 \\
1 / / X \text { or } 1 / / Z \text { and } 2 / / X \text { or } 2 / / Z
\end{array}\right. \\
& 1.1 \pi_{1 / 2} \\
& \left.1 / / X^{-} \text {or } 1 / / Z \text { and } 2 / f\right)^{\circ} \\
& \left.\ln \pi \frac{52-1}{4}+1\right) \\
& 1 / / \gamma \text { and } 2 / / X \text { or } 2 / / Z \\
& I N \pi_{1 / 2}+\operatorname{IST} \frac{1-1}{4} r \\
& 1 / / Y \text { and } 2 / / Y
\end{aligned}
$$


283

where $I . I T(R)$ is the integer part of the real number $R$. The terms $I_{1}, 1=1 \cdots$ 16 are alien by 
s

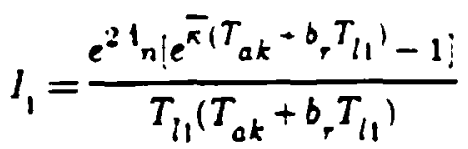

$\therefore$

284

$I_{2}=\frac{e^{2 t_{n}\left(e^{\bar{x}} T_{a k-1}\right)}}{T_{l_{1} T_{a k}}}$

(E.3)

$l_{3}=\frac{e^{\bar{k}\left(T_{a k}+b_{r} T_{l 2}\right)-1 ;}}{T_{12}\left(T_{a k}+b_{r} T_{12}\right)}$

$I_{1}=\frac{\left(e^{\left.\bar{x} T_{a k}-1\right)}\right.}{T_{a k} T_{l 2}}$

$I_{3}=\frac{\mid e^{\overline{\bar{r}}\left(T_{b k}+b_{r} T_{l 1}\right)-1 \mid}}{T_{11}\left(T_{b k}+b_{r} T_{l 1}\right)}$

$I_{6}=\frac{\left(e^{\bar{\pi} T} T_{b k}-1\right)}{T_{b k} T_{12}}$

- $I_{i}=\frac{e^{-2 \cdot t_{n}\left[e^{\bar{k}\left(T_{b k}+b_{r} T_{l 2}\right)}-1\right]}}{T_{l 2}\left(T_{b k}+b_{r} T_{l 2}\right)}$

$I_{8}=\frac{e^{-2.1} n\left(e^{\bar{x}} T_{b k}-1\right)}{T_{12} T_{b k}}$

$I_{0}=\frac{e^{2 \Lambda_{n}+l_{r} \bar{\kappa} T_{a l\left(e^{\bar{T}} T_{k 1}-1\right)}}}{T_{a l} T_{k 1}}$

$I_{10}=\frac{\left.e^{2 A} n \mid e^{\bar{\pi}\left(T_{k 1}+b_{r} T_{a l}\right)}-1\right]}{T_{a l}\left(T_{k 1}+b_{r} T_{a l}\right)}$

$\bar{I}_{11}=\frac{e^{l, \bar{r}} T_{b t\left(e^{\bar{\kappa}} T_{k 1}-1\right)}}{T_{b l} T_{k 1}}$

$I_{12}=\frac{\mid e^{\bar{x}\left(T_{k 1}+b_{r} T_{b l}\right)-1 \mid}}{T_{b d}\left(T_{k 1}+b_{r} T_{b 1}\right)}$

. . I $I_{13}=\frac{e^{\left.\overline{k_{1}} r_{r} T_{a l} e^{\bar{\pi}} T_{k 2}-1\right)}}{T_{a l} T_{k 2}}$ 


$$
\begin{aligned}
& I_{11}=\frac{e^{\bar{\pi}\left(T_{k 2}+b_{r} T_{a l}-1\right.}}{T_{a r}\left(T_{k 2}+b_{r} T_{a l}\right)}
\end{aligned}
$$

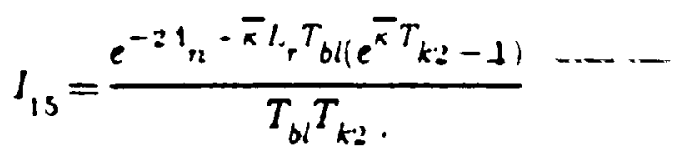

$$
\begin{aligned}
& I_{10}=\frac{e^{-21_{n}\left(e^{\bar{x}\left(T_{k z}+b_{r} T_{b l}\right)}-1\right)}}{T_{b l}\left(T_{k z}+b_{r} T_{b l}\right)}
\end{aligned}
$$

In Eq. E.3.

$$
\begin{aligned}
& T_{a k}=R_{a k}-\frac{x c}{2 \pi}\left(p_{k}+q_{k}+r_{k}\right) \\
& T_{b k}=T_{a k}-2 q_{k} \\
& T_{a l}=R_{a l}-\frac{x c}{2 \pi}\left(p_{l}+q_{l}+r_{l}\right) \\
& T_{b l}=T_{a l}-2 q_{l}
\end{aligned}
$$

'where $R_{a k}$ and $R_{a l}$ are defined by Eq. 0.68 if $\theta$ is substltuted by $\delta$. and

$$
\begin{aligned}
& \text { ' } T_{k 1}=T_{a k}+\frac{\gamma c}{\pi} p_{k} \quad \text { If } p_{k} \text { and } p_{l} \text { haive the same sign } \\
& T_{a k}+\frac{\gamma c}{\pi} q_{k} \quad \text { If } \cdot q_{k} \text { and } q_{l} \text { have the same slgn } \\
& T_{a k}+\frac{x}{\pi} r_{k} \quad \text { If } r_{k} \text { and } r_{l} \text { thave the same sign } \\
& T_{k 2}=T_{k 1}-2 q_{k} \\
& T_{l 1}=T_{a l}+\frac{\gamma c}{\pi} p_{l} \text { if } p_{k} \text { and } p_{l} \text { have the same sign } \\
& T_{a f}+\frac{\gamma c}{\pi} p_{l} \quad \text { if } q_{k} \text { and } q_{a} \text { have the same slgn } \\
& r_{a l}+\frac{\gamma c}{\pi} r_{l} \quad \text { If } r_{k} \text { and } r_{l} \text { have the same siga } \\
& T_{l 2}=T_{11}-2 q_{l}
\end{aligned}
$$

- and

$$
\begin{aligned}
b_{r}=p_{k} / p_{l} & \text { If } p_{k} \text { and } p_{l} \text { have the same slgn } \\
q_{k} / q_{l} & \text { If } q_{k} \text { and } q_{l} \text { have the same slgn } \\
r_{k} / r_{l} & \text { If } r_{k} \text { and } r_{l} \text { have the same slgd }
\end{aligned}
$$

In Eq. E.3, $\lambda_{\eta^{\prime}} \bar{x}$ and $L_{p}$ are siven by Eqs. $6.66,6.72$ and 6.73 , resipectlvely. 


\section{A-2)Three pairs of direction cosines have opposite signs.}

The expanstons for the absolute value terms are given by Fq. 6.87 and the Integration is carrled out on one interval for each of the independent varlables. In thls case. the Integrals $I_{k l}$ are glven by

$$
I_{k l}=e_{1} e_{2}\left(C_{1}(\bar{\theta}) C_{2}(\theta) \frac{r}{4 n^{2}} I_{1}-n_{1} I_{2} I_{13} I_{3}+n_{2} I_{1}\right.
$$
where $e_{1}, e_{2}, n_{1}, n_{2}$ and $\zeta$ are glien by Fos. B.2 to B3.6. respectively and ( 10 , and $C(\theta)$ are glven by Eqs. B.8 and B.9. respectively. if $\theta$ is sumaliuted by $\bar{\theta}$ The terms $I_{1}, l=1 \cdots 4$, are glven by

$$
\begin{aligned}
& l_{1}=e^{1} n\left(e^{\bar{x}} T_{a k}-1\right) / T_{a k} \\
& I_{2}=e^{-1} n\left(e^{\bar{x}} T_{b k}-1\right) / T_{b k} \\
& I_{3}=e^{1} n\left(e^{\bar{x} l} \cdot T_{a l}-1\right) / T_{a l} \\
& I_{4}=e^{-I_{n}\left(e^{\bar{k}} l_{r} T_{b l}-1\right) / T_{b l}}
\end{aligned}
$$

where $A_{n} \cdot \bar{\kappa}$ and $L_{r}$ are given by Fqs. 6.66, 6.72 and 6.73, respectlely and the terms $T_{a k} . T_{b k} \cdot T_{a l}$ and $T_{b l}$ are glven by Eq. E.4.

B)Nodea $n$ and $s$ do not coincide!

B-1) $I_{k l}$ in evaluated on one interval for each of the independent variablea:

The conditions under which this sltuation arises were stated In Subsection 6.6.1 and the expanslons of the absolute value terms are given by Eqs. 6.87 and 6.88 . The Integrals $I_{k l}$ are glven by

$$
\begin{aligned}
I_{k l}= & e_{1} e_{2} \frac{\varsigma}{4 \kappa^{2}} A_{n e} \Delta_{n a} C i(\delta) C 2(\delta) \\
& \left(I_{1}+n_{1} n_{2}\right)\left(I_{3}+n_{2} I_{4}\right)
\end{aligned}
$$

where $e_{1}, e_{2}, n_{1}, n_{2}$ and $s$ are glven by Eas. B.2 to B.6, respectlvely and $A_{n g^{\circ}} C 1(\bar{\theta})$ and $C 2(\bar{\theta})$ are gliven by Eqs. B.7 to B.9. If $\theta$ is substltuted by $\bar{\theta}$. $\Delta_{n \text {. }}$ Is given by 


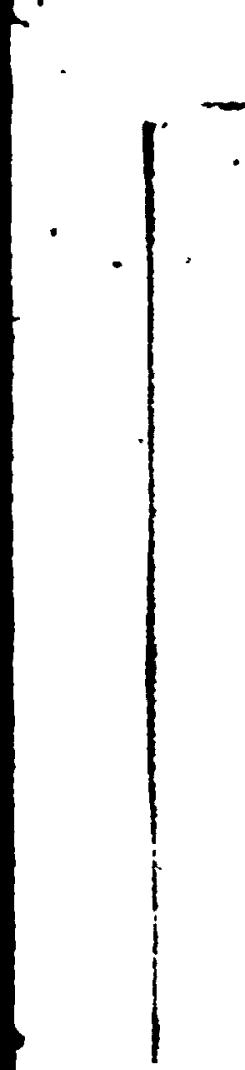

$$
\left.\dot{s}_{n s}=\exp \left\{\frac{-c \kappa \gamma}{2 \pi} x_{n}-x_{s}+y_{n}-y_{*}+z_{n}-z_{n}\right)\right\} \text {. }
$$

and the terms $I_{1}, 8=1 \cdots 4$ are given by

$$
\begin{aligned}
& I_{1}=e^{l_{n}}\left(e^{B_{a k^{k}}}-1\right) / B_{a k} \\
& I_{2}=e^{-l_{n}}\left(e^{\beta_{b k} \bar{x}}-1\right) / B_{b k} \\
& I_{3}=e^{l} \times\left(e^{B} a l^{l} \cdot r^{\bar{\kappa}}-1\right) / B_{a l}
\end{aligned}
$$

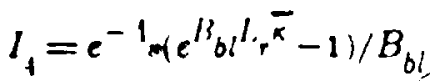

where

$$
\begin{aligned}
& B_{a k}=R_{a k}-\frac{\gamma c}{2 \pi}\left(m_{1} p_{k}-m_{3} q_{k}+m_{s} r_{k}\right. \\
& B_{b k}=B_{a k}-2 q_{k} \\
& B_{a l}=R_{a l}-\frac{\gamma c}{2 \pi}\left(m_{2} p_{l}+m_{1} q_{l}+m_{b} r_{l}\right) \\
& B_{b l}=B_{a l}-2 q_{l}
\end{aligned}
$$

in which
$28:$

$-$

$1 F .12$ 


$$
\begin{aligned}
& -p_{k} / p_{k} \quad s_{n}<x_{\text {. }} \\
& m_{1}=1.0 I_{n}=I_{\text {. }} \\
& P_{h} / P_{k} \quad I_{n}>I_{\text {. }} \\
& p_{i} / p_{l} \cdot \quad I_{n}<I_{n} \backslash \\
& m_{2}=\quad 1.0 I_{n}=I_{\mathrm{N}} \\
& -p_{l} ! p_{l} \quad x_{n}>I_{n} \\
& -q_{k} / q_{k} \quad y_{n}<y_{*} \\
& m_{3}=\quad 1.0 \quad y_{n}=y_{*} \\
& q_{k} / q_{k} \\
& y_{n}>y_{*} \\
& q_{1}^{\prime} q_{l} \\
& y_{n}<y_{*} \\
& m_{i}=\quad 1.0 y_{n}=y_{*} \\
& -q_{l}^{\prime} q_{l} \\
& y_{n}>y_{*} \\
& m_{i}=\quad \cdot 1.0^{-r_{k} / r_{k}} z_{n}=z_{i} \\
& r_{k} / r_{k} \cdot z_{n}>z_{\text {. }} \\
& -r_{1} / r_{l} \quad z_{n}<z_{0} \\
& m_{n}=\quad 1.0 z_{n}=z_{.} \\
& r_{1} / r_{1} \\
& z_{n}<z_{n} \\
& z_{n}>:
\end{aligned}
$$

In Egs. E.11. and E.12, $A_{n}, 1_{n}, \bar{\kappa}$ and $L_{r}$ are glven by E.gs. 8.66, 6.6i. 6.72 and 6.73. respectlvely and $R_{a k}$ and $R_{a l}$ are given by E.q. 6.69. If $\theta$ is substluted by $\theta$. B-2) $I_{k l}$ is evaluated on two intervals for one of the independent variablea:

The Integrals $I_{k l}$ are glven by

$$
I_{k \cdot 1}=e_{1} e_{2} \operatorname{Cl}(\theta) C_{2}(\theta) \frac{\zeta}{4 \kappa^{2}} \cdot 1_{n \cdot *} \Delta_{n \times}\left(\sum_{1=1}^{1+}(-1)^{n_{1} I}\right)
$$

where $I_{i} .2=1 \cdots 16$ are glven by 


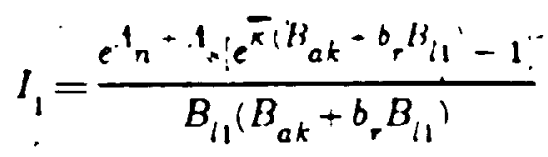

$$
\begin{aligned}
& I_{z}=\frac{e^{1_{n}+1_{a} \cdot\left(e^{\pi} B_{a k}-1\right)}}{B_{l_{1}} B_{a k}}
\end{aligned}
$$

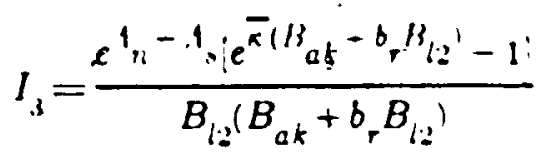

$$
\begin{aligned}
& I_{1}=\frac{e^{1_{n}-1_{k}\left(e^{\bar{x}} B_{a k}-1\right)}}{B_{a k} B_{l: 2}} .
\end{aligned}
$$

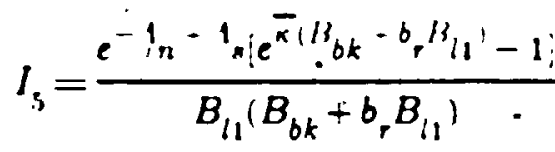$$
I_{6}=\frac{e^{-I_{n}-I_{v}\left(e^{\bar{k} / B_{b k}}-1\right)}}{B_{b k} B_{l 2}}
$$

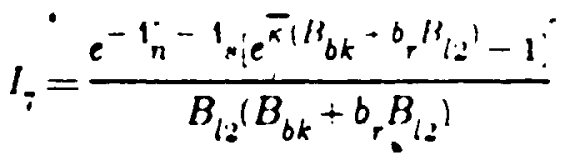$$
I_{k}=\frac{\left.e^{-1_{n}}\right\urcorner^{1} \cdot\left(e^{\left.\bar{x} H_{b k}-1\right)}\right.}{B_{1: 2} B_{b k}}
$$

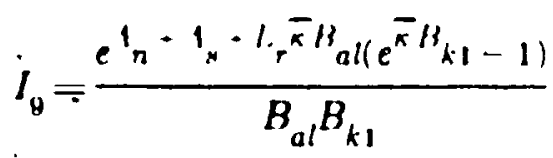

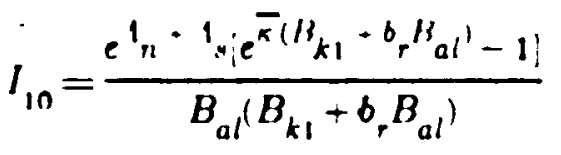

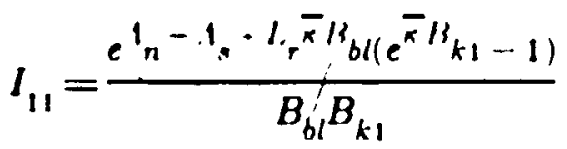

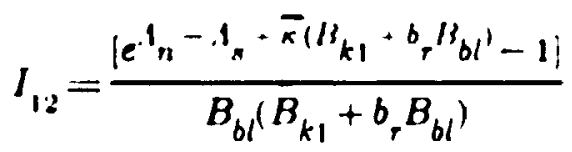

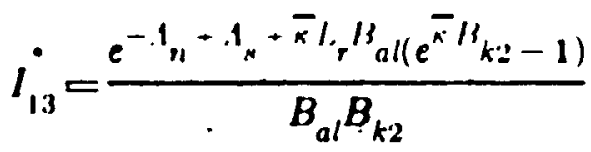




$$
\begin{aligned}
& I_{11}=\frac{e^{-I_{n}-I_{N}\left(e^{\bar{X}\left(b_{k 2}+b_{r} B_{a l}\right.}-1\right)}}{B_{a l}\left(B_{k 2}+b_{r} B_{a l}\right)} \\
& I_{15}=\frac{e^{-I_{n}-I_{s}-\bar{x} l_{r} B_{b l(} e^{\left.\bar{x} B_{k 2}-1\right)}}}{B_{b l} B_{k 2}} \\
& I_{10}=\frac{e^{\left.-q_{n}-1_{s i} e^{\bar{x}\left(B_{k 2}+b_{r} B_{b i}\right)}-1\right]}}{B_{b i}\left(B_{k 2}+b_{r} B_{b l}\right)}
\end{aligned}
$$

in whlch

$$
\begin{aligned}
& -\quad B_{k 1}=B_{a k}+\frac{r_{\pi}}{\pi} m_{1} p_{k} \quad p_{k} \text { and } p_{l} \text { have the same slgn. } \\
& B_{a k}+\frac{c r}{\pi} m_{3} q_{k} \quad q_{k} \text { and } q_{l} \text { have the same sign. } \\
& B_{a k}+\frac{r}{\pi} m_{s} r_{k} \quad r_{k} \text { and } r_{l} \text { have the same sign } \\
& B_{k 2}=B_{k 1}-2 q_{k} \\
& B_{l 1}=B_{a l}+\frac{c r}{\pi} m_{2}^{\prime} p_{l} \quad p_{k} \text { and } p_{l} \text { have the same sign } \\
& B_{a l}+\frac{c \gamma}{\pi} m_{1} q_{b} \quad q_{k} \text { and } q_{l} \text { have the same sign } \\
& B_{a l}+\frac{r}{\pi} m_{8} r_{l} \quad r_{k} \text { and } r_{l} \text { have the same slg } \\
& B_{l: 2}=B_{l 1}-2 q_{k}
\end{aligned}
$$

In Eq. E.16. the $m$, terms are denned by Eq. E.13. 


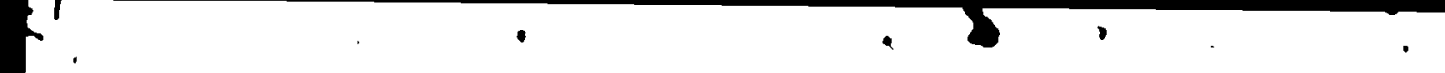

\title{
Appendix F \\ Computer Programs Used in the Study
}

\begin{abstract}
All the necessary computer programs for thls study were developed by the author except the subroutines used for equation solving and evaluation of elgenvalues. The name and purpose of each of the computer programs are glven below:
\end{abstract}

SMIT1

Performs the plle driving analysls using the original Smith model.

SMIT2

Performs the plle driving analysls using, the proposed soll model.

FEM

Finlte element analy'sls in the requency domain implementation and verincation of the transmitung boundarles).

PFEM Finlte element analysls for the plle drikng in the time domaln.

SPECT - Evaluates the spectra of wave forces on members of offshore towers for the three different models.

PGRP Calculates the plle group stiffness constants taking into account dynamlc olle-soll-plle-iateraction.

OFFSH Evaluates the foundation stifrness matrlx for the offshore. - tower.

RESPO Calculates the response of the tower to random wave forces.

All these programs were developed using the CYBER 83.5 computer at the Linliersly of Western Ontarlo Computer Center. 



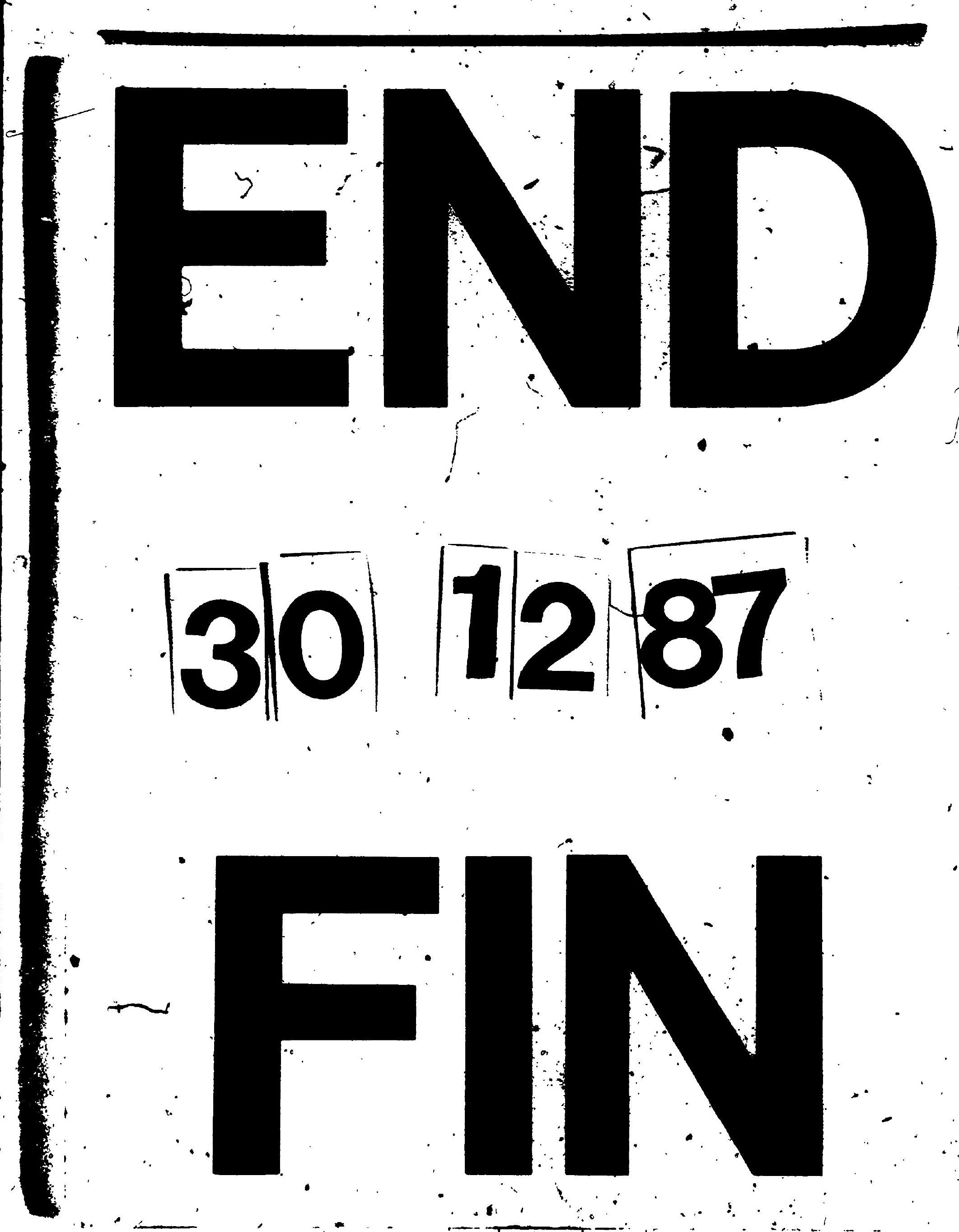

